JOVACY PETER FILHO

\title{
REINTEGRAÇÃO SOCIAL
}

\section{UM DIÁLOGO ENTRE A SOCIEDADE E O CÁRCERE}

Dissertação apresentada à Banca examinadora da Faculdade de Direito da Universidade de São Paulo, como exigência parcial para a obtenção do título de Mestre (área de concentração Direito Penal, Medicina Forense e Criminologia), sob a orientação do Professor Associado Alvino Augusto de Sá.

Faculdade de Direito da Universidade de São Paulo

São Paulo - 2011 


\section{REINTEGRAÇÃO SOCIAL UM DIÁLOGO ENTRE A SOCIEDADE E O CÁRCERE}

JOVACY PETER FILHO

DATA:

BANCA EXAMINADORA:

$1^{\circ}$ Examinador

Orientador: Professor Associado Alvino Augusto de Sá

$2^{\circ}$ Examinador (a)

$3^{\circ}$ Examinador (a) 
"Na condição de ser primeira morada do mundo, cada ser humano traz em si o dom de transformar o mundo inteiro, mas isso só será possível se ele viver o constante desafio de não perder-se de si mesmo."

Pe. Fabio de Melo. 


\section{AGRADECIMENTOS}

Agradeço a Deus pela experiência da re-invenção pessoal, pela misericórdia, pelo estímulo e otimismo para prosseguir na jornada. A Sua luz irradiou muitos dias sombrios e o calvário me permitiu a conversão. Obrigado por ter me ajudado a levar a cruz quando eu, incrédulo, acreditei que iria sucumbir.

A Nossa Senhora, Minha Mãe que Roga por mim em todos os momentos da minha existência e me faz sentir o carinho de sua presença. Aos Padres Fábio de Melo e Marcelo Rossi pelas reflexões profundas e transformadoras. Deus os abençoe!

Aos meus pais Jô e Milca. Faltam palavras para expressar minha gratidão, mas o meu coração palpita de felicidade ao se lembrar de vocês. O menino cresceu e com dignidade vai trilhando seu caminho. A minha história vai sendo escrita com a tinta que nos é comum. Somos muitos e ao mesmo tempo somos uma unidade. A Minha irmã, Sâmea, cujo núcleo vital nos é comum e a ele estaremos para sempre ligados.

À minha esposa Livia: mulher, mãe, amiga... o seu exemplo de fidelidade, de perseverança fez muita diferença na minha vida, e nós dois sabemos disso. Não há nada mais edificante do que ser verdadeiramente amado por alguém, e você me proporciona essa experiência com o seu cuidado diário. Espero continuar sendo digno de sua doce presença em minha vida e espero partilhar com você o melhor de mim.

A Maria Luiza e Maria Clara, minhas filhas, que me apresentaram a paternidade e junto com ela a dáviva da doação espontânea que faz brotar um amor ágape em nossos corações.

À meu sogro Sebastião José Borgo que não estará fisicamente comigo, mas se fará presente para sempre em meu coração. Como disse Mia Couto, "morto amado nunca pára de morrer" e eu certamente nunca vou me esquecer de seu exemplo de vida. À minha sogra Maria José, que é como uma mãe para mim, que esteve comigo nos momentos difíceis e não há de faltar na alegria da chegada. Meus cunhados e cunhadas, em especial Bruno, Aline, Tiago, Sandro e Tatiana. 
Aos meus tios de sangue (Famílias Tenório e Peter) e aos meus tios de coração (os “Claudino”), que sinto mesmo à distância as energias do bem que todos me transmitem!

Ao professor Alvino Augusto de Sá, a quem eu não continuo chamando de "Professor" por acaso. O senhor é um modelo de ser humano; um mestre das palavras, do afeto, da cordialidade e da escuta devotada. Um sábio no mais exato sentido da expressão. Talvez não seja possível divisar quanto do senhor está neste trabalho e talvez nem mesmo eu saiba por certo o que é meu e o que é herança direta sua; marcas de sua presença sensível e gratificante em minha vida. Estendo minhas homenagens à querida e zelosa Cléia, minha mãe paulistana, e, claro, aos meus “irmãos postiços” Daniel, Marcelo e Juliana pela recepção carinhosa de sempre.

Ao meu amigo e mestre Daury Cezar Fabriz a quem, apesar da amizade, eu tenho dificuldade de suprimir-lhe o título de "professor", pois foi o meu grande incentivador à vida acadêmica e pessoa que espero caminhar ao lado até quando "Deus quiser".

Ao amigo Bruno Bracco, que teve fundamental participação neste trabalho, sempre com sugestões pertinentes e uma leitura atenta do texto. Obrigado meu caro por ter me aberto este canal de diálogo.

Meus agradecimentos finais a todos os colegas da FADUSP, do GDUCC, das Faculdades Integradas Campos Salles, do Complexo Jurídico Damásio de Jesus (CJDJ), Central de Concursos, GOE-Claretiano, Escritório de Advocacia Podval e ABDH. Meus contatos acadêmicos e profissionais fazem parte da minha história, e nada pode estar fora dela no momento de consagrar o presente.

A todos os meus alunos que me dão a certeza de que a docência crítica e reflexiva é capaz de libertar o espírito! 


\section{SUMÁRIO}

\section{Resumo / Abstract \\ INTRODUÇÃO. \\ 1. CLÁSSICAS ESTRATÉGIAS DE INTERVENÇÃO NO HOMEM ENCARCERADO: O ESTÁGIO DE ENSIMESMAMENTO PENITENCIÁRIO

1.1. Tratamento penitenciário .10

1.1.1. Cesare Lombroso e a "marca de Caim".......................................................................11

1.1.2. O positivismo criminológico e seu legado para o cárcere ...........................................23

1.1.3. Cenários teóricos contemporâneos do tratamento penitenciário...................................34

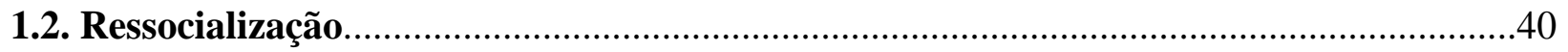

1.2.1. O cenário de emergência do ideal ressocializador................................................45

1.2.2. Premissas políticas e filosóficas do conceito de ressocialização..................................60

1.2.3. Cenários teóricos contemporâneos da ressocialização.................................................71

2. DA TRANSIÇÃO À REINTEGRAÇÃO SOCIAL: UMA PROPOSTA DE

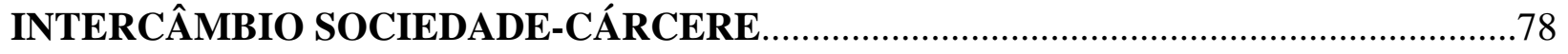

2.1. Da idéia de ressocialização à ressocialização da idéia: divisando os limites (e as diferenças) entre as propostas de Ressocialização e Reintegração Social..........................78

2.2. Integração, desintegração e Reintegração Social: harmonizando os contrários da realidade.

2.3. A Reintegração Social, exclusão e criminalidade 
2.4. Fundamentação filosófica da Reintegração Social: o homem e a inter-

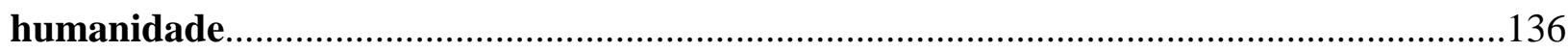

2.4.1. Quem é o homem para a Reintegração Social?............................................................136

2.4.2. O diálogo e a redescoberta do amor-de-si .....................................................................152

2.5. Reintegração Social e os vetores convergentes de responsabilidade................................161

3. REINTEGRAÇÃO SOCIAL E EXECUÇÃO PENAL: DIRETRIZES DE

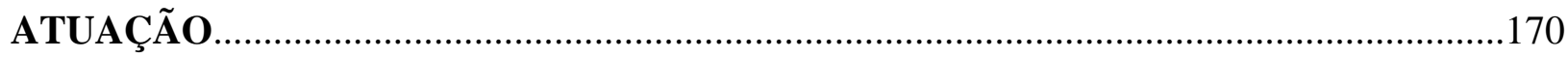

3.1. A quem se destinam as diretrizes de Reintegração Social? ...........................................170

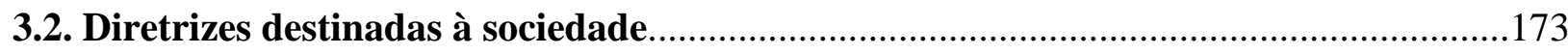

3.2.1. Reintegração e conversão social..............................................................................174

3.2.2. Reintegração Social e municipalismo: a capilarização da mensagem.................................177

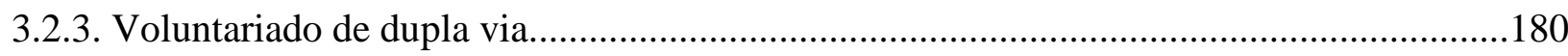

3.2.4. Reconhecimento legal da Reintegração Social................................................................182

3.2.5. Reintegração Social e arquitetura penitenciária...................................................................184

3.2.6. O papel do criminólogo perante a Reintegração social.....................................................185

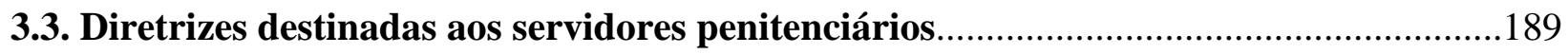

3.3.1. A Reintegração Social enquanto diretriz curricular na formação da equipe

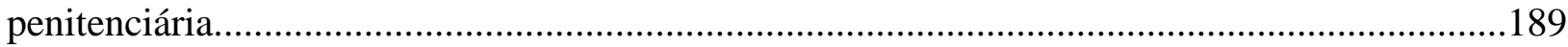

3.3.2. Simetria e abrangência das ações de Reintegração Social.....................................................192

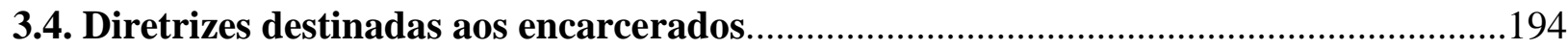

3.4.1. Leitura prévia do campo............................................................................................194

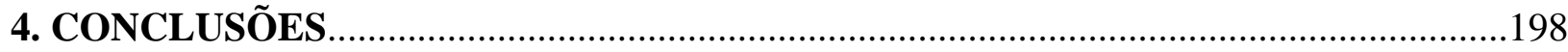

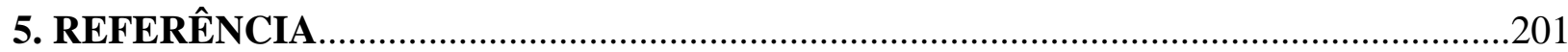




\title{
RESUMO
}

A presente pesquisa consistiu em identificar, a partir de um enfoque crítico e clínicocriminológico, o que caracteriza e singulariza a Reintegração Social frente às demais propostas político-criminais tradicionalmente aplicadas ao cenário da execução penal. A partir deste objetivo, foram sendo desdobradas as filigranas das clássicas estratégias político-criminais (tratamento penitenciário e ressocialização) a fim de investigar a proximidade os limites teóricos entre elas e a Reintegração Social, além de se debruçar na idéia que propõe uma filosofia dialogal como mecanismo de aproximação e identificação plurais entre a sociedade e o cárcere.

Palavras-Chave: Reintegração Social - Tratamento Penitenciário - Ressocialização - Diálogo Sociedade - Cárcere.

\begin{abstract}
The present research was to identify, from a critical, clinical and criminological, which characterizes the Social Reintegration against other proposals for criminal policy traditionally applied to the landscape of criminal enforcement. From this goal, the watermarks have been deployed on classical criminal policy (prison treatment and social rehabilitation) to investigate the theoretical limits of the closeness between them and Social Reintegration, and to address the idea that proposes a dialogical philosophy as a mechanism approach and identification of plural society and prison.
\end{abstract}

Keywords: Social Reintegration - Treatment Penitentiary - Resocialization - Dialogue- Society Jail. 


\section{INTRODUÇÃO}

A tarefa de investigar os horizontes da reintegração social impõe uma série de percalços, especialmente os que se relacionam com a delimitação de seu conceito e de suas possibilidades de aplicação. Até por isso, numa primeira aproximação, talvez fosse mais fácil a empreitada de dizer o que a reintegração social não é. Não se trata de um sinônimo de tratamento penitenciário, nem de uma compilação de práticas correcionais. Também não se equivale à ressocialização - e isso apenas para citar as clássicas abordagens promovidas no cenário do cárcere. Mas fosse ainda assim, restaria um conceito tão abrangente quanto vazio.

Não que tal circunstância inviabilizasse sua aplicação no âmbito das políticas penitenciárias. Pelo contrário, seu uso meramente retórico abrigaria a diversidade de ideologias que circundam o contexto, especialmente aquelas que pretendem justificar e amplificar o cárcere e os seus métodos de punição ${ }^{1}$. Aliás, prescrições das mais variadas são propostas, sobretudo aquelas dirigidas aos encarcerados, na esperança de promover-lhes a cura de seus males.

Também sobram terapêuticas que se reproduzem à base de receitas malogradas, ainda que em muito menor escala sejam os investimentos voltados a diagnosticar os fatores de fracasso e trabalhar para minorá-los. Resta, assim, uma cadeia de conformidades: já se conheceu de

\footnotetext{
${ }^{1}$ No mesmo sentido escreveu Raúl Cervini (Os processos de descriminalização. Trad. da $2^{\mathrm{a}}$ ed. espanhola Luiz Flávio Gomes. São Paulo: RT, 1995, p.33), abordando a inconsistência do conceito de ressocialização: "É claro que ninguém ocupou-se de dar um conteúdo concreto e determinado à expressão 'ressocialização'. Provavelmente, contudo, a chave de sua aceitação geral funda-se nesta mesma falta de precisão, uma vez que cada um atribui-lhe um conteúdo e finalidade distintas de acordo com sua ideologia pessoal". Também o penalista e criminólogo espanhol Francisco Muñoz Conde (Apud. Ribeiro, Bruno de Moraes. As modificações recentes havidas no conceito de ressocilização ou reintegração social e a discussão atual acerca desse conceito. In: Prado, Luiz Regis. Direito Penal Contemporâneo: estudos em homenagem ao professor José Cerezo Mir. São Paulo: RT, 2007, p. 110 (nota n.1) expressou preocupação similar ao abordar a questão da ressocialização, provando assim que o artifício da indeterminação conceitual é recorrente no campo penitenciário, exatamente na pretensão de forjar uma idéia politicamente bonita, mas de conteúdo abstrato, e que quase tudo legitima. Assim, retratando o aspecto da indeterminação como algo proposital, ressalta Muñoz Conde que "esta mesma indeterminação e vagueza é o que provavelmente confere a chave de seu êxito, porque todo mundo pode aceitar o termo, ainda que depois cada um lhe atribua um conteúdo e finalidades distintas de acordo com sua ideologia pessoal. Essa mesma indeterminação é, sem embargo, e ao mesmo tempo, seu principal defeito, pois que não permite nem um controle racional, nem uma análise séria de seu conteúdo. O termo ressocialização se converteu em uma palavra da moda que todo mundo emprega, sem que nada se saiba muito bem o que é e o que se quer dizer com ele".
} 
tudo; já se tentou de tudo; já se esperou de tudo. Esta idéia de que nada de novo se produz em relação ao cárcere não é falsa, mas deve ser avaliada com cautela, para que o fracasso da instituição não venha a lançar suas trevas sobre as relações humanas que sempre podem transcender a qualquer adversidade, por maior que seja. A descrença no cárcere não pode impor a mesma desesperança para com o homem que nele habita, e isso há de ser ressaltado. Se as relações humanas padecem com o encarceramento, e isso ninguém nega, tal não quer dizer que estejam destinadas irremediavelmente ao isolamento e ao etiquetamento que lhes promove o cárcere.

Nas palavras de MORIN \& CASTEL, citados por BADER SAWAIA ${ }^{2}$, esta fragilidade teórica tão comum nas discussões afeitas ao cárcere é típica de conceitos "mala ou bonde", ou seja, aqueles que permitem qualquer uso e interpretação e têm o papel de adormecer a crítica ao provocar um consenso letárgico, sem que se tenha a exata dimensão dos reais significados postos em jogo. E este é um perigo que se deve evitar, pois se os parâmetros conceituais não forem claros, menos ainda o serão as práticas que neles se baseiam.

Até por isso se faz tão importante quanto seguro que a investigação científica venha a inserir o conceito de reintegração social numa composição bem definida, ainda que sem a aspiração de esgotá-lo totalmente nela.

Neste plano, o objetivo do presente trabalho consiste em identificar, a partir de um enfoque crítico e clínico-criminológico, o que caracteriza e singulariza a reintegração social frente às demais propostas político-criminais tradicionalmente aplicadas ao cenário da execução penal, entendida aquela essencialmente como via ou canal de diálogo nas relações humanas estabelecidas entre o encarcerado e a sociedade

\footnotetext{
${ }^{2}$ Sawaia, Bader. Exclusão ou inclusão perversa? In. Sawaia, bader (Org.). As artimanhas da exclusão: análise psicossocial e ética da desigualdade social. $10^{\mathrm{a}}$ ed. Petrópolis/RJ: Vozes, 2010. p.07.
} 
Impõe ressaltar que tais processos se desdobram apesar $^{3}$ ou além do cárcere, e não propriamente em função dele, pois que se apropriam das relações humanas que se projetam desde a vida pregressa ao encarceramento, ou seja, se interessam com a história do homem para, em seguida, analisar os vieses da privação de liberdade em vistas ao retorno à sociedade extra-muros. Trata-se de uma visão holística do fenômeno do encarceramento, e não uma abordagem analítica, centrada em aspectos particulares e que em geral não se comunicam ${ }^{4}$. Não deixa de ser um ponto de partida para o trabalho entender como essas relações se formam, se desagregam e são posteriormente devolvidas ao corpo social, após a experiência do encarceramento.

A análise, como já ponderado, nem de longe pretende justificar as práticas punitivas já observadas no cárcere, nem mesmo contribuir para a sua expansão, revestindo-o de um aparente altruísmo. Não há como listar com exatidão os prejuízos decorrentes do encarceramento, sobretudo no contexto humano, mas ainda assim sobrevive por trás da penumbra do cárcere, e nem mesmo o maior dos sofrimentos é capaz de soçobrar, a capacidade humana de se reinventar, de estabelecer e renovar laços de intersubjetividade, reconstruindo a si e ao seu entorno.

A reintegração social se interessa não pelo preso, pelo agente penitenciário, pelos Diretores e gestores prisionais, senão que pelos homens e mulheres que estão na base dos papéis que

${ }^{3}$ Esta idéia, assim como a fonte da qual ela se origina, servirá de base para o desenvolvimento do presente estudo. Em essência, ela se propõe a analisar o cárcere e os desdobramentos de sua existência não apenas por meio de sua realidade imanente, que não raro é castradora, mas pretende tocá-la passando, primeiro, por uma investigação que vai do transcendente, das possibilidades que vão além do cárcere, para retornar à realidade com o intuito de transformá-la. A referência bibliográfica deste pensamento está em Alessandro Baratta (Por um concepto critico de reintegración social Del condenado. In: Oliveira, E. [Coord.]. Criminologia crítica. Fórum Internacional de Criminologia Crítica. Belém: Cejup, 1990. p.141-157).

${ }^{4}$ As clássicas abordagens realizadas no cenário penitenciário, e que serão trabalhadas na sequência desta introdução, tratam de circunscrever a vida do homem encarcerado ao período de reclusão, e daí extrair as conclusões acerca do prognóstico da conduta do mesmo visando um posterior retorno à vida em liberdade. Esquecem que o homem não se cria no cárcere, mas apenas se reinventa nele, e da mesma forma que o cárcere, tal como é, recria o ser, é possível que uma abertura do cárcere possa inferir uma reinterpretação do homem que é privado de sua liberdade. Ocorre que apenas a consideração integral do homem enquanto ser que vai muito além do infrator, se é que de fato transcrediu alguma norma social, é capaz de aproximá-lo da sociedade e fazer a sociedade se aproximar dele. 
desempenham, e que os tornam semelhantes e pertencentes a uma mesma sociedade, por mais eclética, inclusiva ou exclusiva que ela seja. Na essência, todos nós somos um ${ }^{5}$.

E sendo o homem um ser criativo por excelência, sempre haverá possibilidades a identificar, que vão além do cárcere. E não se trata de uma mera divagação ou utopia acadêmica ${ }^{6}$, tal como uma análise desgarrada da realidade, mas se refere a uma abordagem contextualizada com a experiência e com os inúmeros desdobramentos que ela tende a promover.

Para isso, mais do que limitar o discurso a um emaranhado de argumentos fatalistas e céticos, que se de um lado são válidos para denunciar o quadro por outro acabam por prostar-se perante ele, é preciso, como indicou LuIZ EDUARDo SOARES ${ }^{7}$, superar as abordagens que somente apreendem os aspectos negativos do cárcere, e nada ou muito pouco propõem para a superação do que denunciam.

Por mais que o cárcere seja um assunto recorrente, em pesquisas ou em conversas, ele ainda carece de enfrentamentos que rumem para além do terreno das críticas, na perspectiva de

\footnotetext{
${ }^{5}$ Esta idéia não retrata uma miragem ou um embuste semântico. Basta considerar que ela se liga intimamente à visão de homem que se pretende utilizar, bem como aos desdobramentos e possibilidades que tal escolha acarreta. O fisósofo francês X. Zubiri (Apud, Beristain, Antonio. Re-encantamento criminológico en projimidad desde el des-encantamiento. In: Beristain, Antonio. Derecho Penal, Criminologia y Victmologia. Curitiba: Juruá, 2007, p. 247), ao dissertar sobre o homem, afirma que "não há esperança (re-encantamento) alheia ao nível do nós", ao que o criminólogo espanhol Antonio Beristain traduz esta fala como a capacidade do homem de viver para o outro, e isso o torna um ser efetivamente humano, pois que mesmo o plano individual encontra-se constitucionalmente afeito a realidades que transcendem ao plano singular e remetem ao plural. O homem é fruto de simbisose, nasce da união e não do ensimesmamento. O homem, nesta concepção, é predisposto de forma inata ao diálogo, eis que nas palavras de Beristain (Idem, Ibidem) "há uma simpatia cósmica, não dual, que une ao seu redor todos os seres do universo."

${ }^{6}$ Se bem que, tratando do conceito de utopia, Luiz Eduardo Soares empreendeu uma interessante reflexão que faria muito sentido ao contexto aqui laborado, uma vez que falava de distanciamentos sociais promovidos pela exclusão: "O muro. Seria preciso? Seria bom falar dele sem abrir-lhe uma fenda? Seria certo identificá-lo sem atravessá-lo com uma ponte, com o sonho da ponte? Sim, o sonho da ponte, nem que fosse como utopia, o sonho do território humano planetário sem fronteiras. Por que não? Utopias são tipos ideais regulatórios, irreais, inexistentes, porém úteis como bússulas, que nos ajudam a descobrir para onde apontar nossos desejos." (In. Soares, et alii. Cabeça de porco. Rio de Janeiro: Objetiva, 2005. p.85).

${ }^{7}$ Soares, et alii. Op. cit. p.72. O trecho mencionado, como indica o próprio autor, foi extraído do pensamento exposto por Miriam Guindani, em sua tese de doutoramento defendida na PUCRS, intitulada Violência e prisão: viagem em busca de um olhar complexo.
} 
reduzir os danos, e a fim de valorizar o que há de vital e construtivo sob a imagem de assombro, driblando a retórica destrutiva que não aponta caminho algum e só contribui para degradar o resto de auto-estima que ainda reste, aqui e ali, entre destroços humanos e institucionais.

Com esta direção provocativa, mas igualmente construtiva no aspecto do humano, o trabalho se dividiu em três grandes capítulos, que convergem para a seguinte problemática: É possível ir além do pessimismo e da intolerância que acompanham as relações de encarceramento, a fim de vislumbrar um prognóstico menos traumático para os atores que transitam em torno da realidade carcerária?

O capítulo primeiro propõe realizar uma revisão das clássicas teorias que propuseram modalidades de recuperação do homem, e que foram denominadas de estratégias de intervenção no encarcerado. Assim, serão apresentadas as diretrizes e fundamentos do tratamento penitenciário e da ressocialização, a fim de buscar uma reinterpretação destes conceitos à luz da reintegração social.

O capítulo segundo ingressará propriamente no tema da reintegração social, propondo limites teóricos ao próprio conceito, estabelecendo liames entre o criminológico, o político, o social e o filosófico, a fim de definir suas condições de emergência e manutenção da idéia inserida ao cenário penitenciário. Em resumo, será o espaço em que o objetivo da pesquisa será sensivelmente trabalhado.

O capítulo terceiro buscará transportar a discussão para o campo propriamente dito das políticas penitenciárias, investindo em assuntos afeitos à execução penal brasileira, ao propor uma harmonização e um diálogo das experiências atestadas com as bases teóricas apresentadas, isto é, com o conceito de reintegração social. 
Assim, a abertura do cárcere será pensada com base em práticas concretas, tais como a aproximação da academia, a questão da formação dos técnicos penitenciários, da avaliação dos programas apresentados no cenário do cárcere e também daqueles realizados sobre o homem encarcerado, bem como do papel dos Conselhos Penitenciários e de Comunidade neste contexto.

Os métodos de abordagem ${ }^{8}$ adotados no presente trabalho serão o hipotético-dedutivo e o dialético. Com o auxílio do primeiro se levantará o problema de pesquisa e as hipóteses a ele vinculadas para, em seguida, iniciar o processo de falseabilidade e inferência dedutiva, com a finalidade não de chegar necessariamente a respostas, mas sim a novos problemas. Como disseram Marconi \& Lakatos ${ }^{9}$ : "O crescimento do conhecimento marcha de velhos problemas para novos por intermédio de conjecturas e refutações”. O método dialético servirá para auxiliar a tarefa de singularizar a reintegração social perante um quadro tensionado entre as limitações impostas pela realidade e as possibilidades fornecidas pela interpretação da teoria ${ }^{10}$.

\footnotetext{
${ }^{8}$ Utilizaremos a classificação de Marconi \& Lakatos (Marconi, Marina de Andrarde; Lakatos, Eva Maria. Fundamentos de metodologia científica. $5^{\text {a }}$ Ed. São Paulo: Atlas, 2003, p. 106), para quem o método de abordagem não se identifica com os métodos de procedimento. Segundo as autoras: "Método e métodos situamse em níveis claramente distintos, no que se refere à sua inspiração filosófica, ao seu grau de abstração, à sua finalidade mais ou menos explicativa, à sua ação nas etapas mais ou menos concretas da investigação e ao momento em que se situam."

${ }^{9}$ Idem. Ibidem, p. 97.

${ }^{10}$ Certo que mesmo está divisão de caráter meramente ilustrativo não pode ser considerada de forma polarizada, pois, como serão apresentados no capítulo final desta pesquisa, tanto a realidade pode brindar o estudioso com novas possibilidades (por vezes surpreendentes) quanto, por outro lado, a teoria pode vir chancelar uma postura prostrante perante os fatos que intenta analisar em cotejo com as experiências sociais que lhes emprestam sentido.
} 


\section{CLÁSSICAS ESTRATÉGIAS DE INTERVENÇÃO NO HOMEM ENCARCERADO}

Escrevendo sobre as pretensões jurídico-penais que se levantam em torno da punição e de seus ideais, IÑAKI RIVERA BEIRAS ${ }^{11}$ assinala que:

“(...) quando se fala de funções, semelhantes discursos jurídico-penais somente podem descrever os supostos efeitos que a pena deveria cumprir; (...). É claro assinalar que nada disso tem a ver com as funções que materialmente cumprem os sistemas punitivos na realidade, já que tal questão, por pertencer ao universo sociológico, (quase) nunca foi ressaltada por aquele discurso jurídico hegemonico. Em tal sentido, semelhante discurso, em que pese a intenção de construir autênticas teorias da pena, se limitou ao estágio - na melhor das hipóteses - de construção de simples mitologias do castigo; o que, nem por isso (...) deixaram de cumprir um claro papel ideológico."

$\mathrm{O}$ autor se refere expressamente às construções penais para formular sua crítica acerca dos fins preconizados à pena. Mas ao abordar o tema, retratando o papel desempenhando pela ideologia na condução das políticas punitivas (em especial quando a teoria é frágil ao não cumprir o seu papel de clarear e orientar os programas políticos), deixou aberta uma reflexão que transcende o cenário jurídico. Por meio da punição será possível obter algum outro objetivo além daquele de expurgar o punido da sociedade?

${ }^{11}$ Beiras, Iñaki Rivera. La cuestión carcelaria - historia, epistemologia, derecho y política penitenciaria. $2^{\mathrm{a}}$ Ed. V. I. Buenos Aires: Del Puerto, 2009. p.51. Também Cezar Roberto Bitencourt (Tratado de direito penal. Vol I. $13^{\mathrm{a}}$ ed. São Paulo: Saraiva, 2008, p. 105) advoga a tese de que o saber penal deve ser transversalizado pela compreensão criminológica, de viés empírico ou com pretensões a fornecer um quadro exploratório mais íntimo e em consonância com a realidade sensível. Assim adverte o professor gaúcho: "Na verdade, a questão da privação de liberdade deve ser abordada em função da pena tal e como hoje se cumpre e se executa, com os estabelecimentos penitenciários que temos, com a infra-estrutura e dotação orçamentária de que dispomos, nas circunstâncias e na sociedade atuais. Definitivamente, deve-se mergulhar na realidade e abandonar, de uma vez por todas, o terreno dos dogmas, das teorias, do dever-ser e da interpretação das normas." 
Talvez esta seja uma das questões mais angustiantes do campo penitenciário, e até os dias de hoje uma das que mais concentram os esforços dos estudiosos das esferas penal e criminológica. Se o cárcere e seu arsenal punitivo desempenham uma função na sociedade, cumpre destacá-los para que se tenha com maior transparência as condições e possibilidades para se atenuar as tensões do campo. E, ao que parece, esta tarefa não começa no cárcere, mas antes mesmo dele.

Voltando os olhos ao percurso histórico, importa lembrar que a criminologia não se furtou ao problema de fornecer conteúdo empírico aos fins da punição. CESARE BECCARIA e sua escola clássica $^{12}$, considerada por muitos como uma orientação pré-científica ${ }^{13}$ no cenário

${ }^{12}$ A escola clássica já destacava a importância das penas no cenário da prevenção do crime, ou seja, já trabalhava com os fins preconizados e normativamente atribuídos à pena. Como destacou Alfonso Serrano Maíllo (Introdução à criminologia. Trad. Luiz Regis Prado. São Paulo: RT, 2007, p. 64), retratando a abordagem clássica dos fins da pena: "Isso é coerente com sua concepção de homem e do delito, já que a pena vai ser imposta ao culpado no caso de cometer o delito e ser descoberto e ser descoberto e condenado é um mal e representa, portanto, um claro prejuízo, que deveria desequilibrar a decisão racional a favor da não-comissão do delito. Assim, afirma-se que o fim da pena 'não é outro que impedir o réu de causar novos danos a seus concidadãos, e afastar os demais de cometer outros iguais', de modo que nessa declaração incluem-se duas finalidades (negativas) da pena: a prevenção especial e a geral".

${ }^{13}$ A criminologia clássica, assim referida por Enrico Ferri (Apud Molina, Antonio Pablos Garcia; Gomes, Luiz Flavio. Criminologia. $6^{a}$ ed. São Paulo: RT, 2008. p. 176, nota de rodapé n.2), não tem posição unânime na história do pensamento criminológico. Para Molina (Op. cit, p.177), "a contribuição da Escola Clássica pertence mais ao âmbito da penologia que ao estritamente criminológico. (...). Como consequência, a Escola Clássica se enfrenta muito tarde com o problema criminal: limita-se a responder ao comportamento delitivo com uma pena justa, proporcionada e útil,mas, não se interessa pela gênese e etiologia daquele nem trata de previni-lo e antecipar-se ao mesmo". Orientação semelhante é assumida por E. Raúl Zaffaroni (Zaffaroni \& Pierangeli. Manual de direito penal brasileiro - parte geral. $4^{\mathrm{a}}$ ed. São Paulo: RT, 2002, p.270), que considera Beccaria um dos "próceres" do pensamento penal, com muito mais penetração nesta seara do que no contexto criminológico. De forma semelhante, Alessandro Baratta (Criminologia crítica e crítica do direito penal. Introdução à sociologia do direito penal. $3^{\mathrm{a}}$ ed. Rio de Janeiro: ICC/Revan, 2002, p.32-34) analisa a obra de Beccaria muito mais sintonizado com sua importância jurídico-penal do que propriamente criminológica. Em sentido contrário, considerando a escola clássica como precursora e partidária da evolução do saber criminológico, Bustos Ramirez (apud, Rivera Beiras, nota n.46), afirmava que a criminologia surgiu como corrente de pensamento a partir dos estudos iluministas do Século XVIII, especialmente com a difusão da obra Dos delitos e das penas de Cesare Beccaria, mas enquanto conhecimento científico, a criminologia somente teria origem nas idéias positivistas do Século XIX, eis que foi neste período que se condensou verdadeiramente um método a este campo de conhecimento. Alfonso Serrano Maíllo, por sua vez, entendia que a escola clássica nascida com as idéias iluministas lastreadas na obra de Beccaria já exprimia uma concepção da criminologia científica, apesar de que "o seu nascimento, tal e como se entende contemporaneamente e que basicamente reclama o recurso ao método científico no estudo do delito e do comportamento humano em geral, remonta somente ao século XIX." (Maíllo, Op. cit, p.68). Apesar de nossa posição partilhar da tese de que a escola clássica não representou em efetivo movimento criminológico, haja vista a adoção de um método lógico-dedutivo distante dos interesses empíricos da criminologia propriamente dita, não refutarmos a utilização para fins didáticos do termo "criminologia 
criminológico, já havia cuidado de estabelecer os fins da pena que, mais tarde, orientariam as construções teóricas manejadas pelo direito penal e por seus interlocutores. Todavia, a abstração dos fins da pena levantados pelos clássicos com referência a um conteúdo normativo por vezes indemonstrável colocava em cheque o tema.

Também o conhecimento científico do século XIX se encontrava penetrado pelas idéias positivistas, cuja essência estava em interpretar todos os campos do saber pautando-se pelas regras das ciências naturais, ou seja, pela observação, medição e comparação com as leis universais e imutáveis que regeriam a vida humana. Isto contribuiu decisivamente para o alvorecer da criminologia, que, pelas mãos de CESARE LOMBROSO, nascia herdeira dos problemas afeitos à punição e que receberam dos clássicos apenas respostas em nível de conjecturas.

E foi pelas mãos de LOMBRoso que surgiu, cientificamente, a primeira abordagem propriamente criminológica e voltada a conferir um sentido concreto à pena, com o claro intuito de justificá-la em sua extensão e danosidade. A estratégia proposta pelo professor de Turim e com um patente viés médico-psicológico ficou conhecida como tratamento penitenciário $^{14}$, que ainda hoje encontra ampla aceitação no campo penitenciário.

Portanto, compreender o funcionamento intelectual e dinâmico sobre o qual se sustenta o tratamento penitenciário dirá muito a respeito de quem pretensamente merece a terapêutica

clássica" ou "criminologia pré-científica" e concordamos com as ponderações de Bustos Ramirez. De toda forma, se afigura como válida a posição conciliatória proposta por Sérgio Salomão Shecaira (Criminologia. São Paulo: RT, 2004, p. 75), sobretudo quando ultima a discussão nos seguintes termos: "Deixando de lado a anedótica (em grande medida) discussão que poderia advir da briga para se ter um 'pai' da ciência criminológica, poder-se-ia dizer, em duas grandes linhas de pensamento, que a criminologia nasce com o positivismo seja sociológico ou biológico; ou, ainda, que a criminologia nasce com a escola clássica." Para uma visão mais abrangente desta discussão, inclusive com várias "tipologias de respostas", Cf. Zaffaroni. E. Raul. Criminología - aproximación desde um margen. $3^{\mathrm{a}}$ reimpressão. Bogotá: Editorial Temis, 2003, p.99-101.

${ }^{14}$ Lombroso utilizava apenas a expressão tratamento. O complemento penitenciário foi acrescido posteriormente , apesar de estar implícito nas conclusões do médico italiano, uma vez que o âmbito de aplicação de seus métodos de tratamento se davam num cenário de reclusão. 
penal e do que esperar como resultado de sua atividade. Ademais, foi a idéia do tratamento o berço de uma variada gama de abordagens político-criminais formatadas para o cárcere, e exemplo disso, como se verá em seguida, foi a "invenção" da ressocialização pretendida através da pena.

\subsection{Tratamento PENitenciário}

Não é fácil encontrar na doutrina criminológica, que já é eclética e pluridisciplinar por natureza, uma unidade conceitual em torno da idéia de tratamento. A polissemia e a variedade de usos da expressão são tamanhas que dificultam, inclusive, a compreensão político-criminal a ser preconizada. Isso sem se falar nos demais sentidos que se entrelaçam direta ou indiretamente ao termo em questão - e os mais conhecidos são ressocialização, reabilitação, emenda, reeducação e reintegração.

Se o conhecimento científico tem por escopo a análise e a sistematização do saber que pretende conhecer, nada mais coerente do que investir numa proposta de organização de cada termo em referência a seus respectivos conteúdos. Não se trata, ao menos neste momento, de uma busca por novos preenchimentos para os signos, mas apenas se cuida de lhes fornecer um formato seguro e preciso, para que possam melhor orientar os seus respectivos horizontes de aplicação. Ainda que as palavras possam ser representadas por conteúdos aproximados, por vezes complementares, não é o caso de descuidar dos limites e dos sentidos que cada um deles possui e que buscam transmitir.

Do contrário, o uso indiscriminado dos termos tenderá a gerar uma incerteza quanto à orientação criminológica verdadeiramente aplicada, ou seja, para os substratos que se encontram na direção política e ideológica do que se propõe. Para iniciar a empreitada de sistematizar os conteúdos analisados serão apresentadas duas abrangentes categorias, dentro das quais se alocarão vertentes que permitem guardam estreita aproximação: a primeira denominada de técnicas de intervenção no homem encarcerado, e que será identificada como 
um conjunto de ferramentas de controle utilizadas pelo aparelho penitenciário; por outro lado, uma segunda categoria englobará as técnicas de compreensão do homem encarcerado, que se darão a partir da interface e do diálogo entre a sociedade e o cárcere.

Assim, as categorias se diferem, essencialmente, em relação às expectativas que desenvolvem no seio da execução penal, se de transformação do homem através do cárcere ou de compreensão do mesmo apesar do cárcere

\subsubsection{Cesare Lombroso e a "marca de Caim"}

O pensamento positivista, do qual a criminologia científica foi tributária em seu estágio embrionário, se contrapôs às idéias empunhadas pela ilustração quando, ao se sustentar sobre uma base filosófica racional, científica e pragmática, deixou de lado as construções consideradas abstratas e utópicas - do iluminismo. Noutros termos, a imaginação atribuída aos iluministas haveria de ceder espaços para a observação dos positivistas. Era assim que Augusto Comte pretendeu interpretar os fenômenos sociais com as invariáveis leis da natureza ${ }^{15}$.

Os fenômenos da vida, quaisquer que fossem suas origens e manifestações, passariam pelo filtro da observação empírica e seriam rigorosamente submetidos à "lei da causalidade" enquanto instrumento descritivo-explicativo do real $^{16}$; e com o crime e toda a sua complexa rede de compreensão não haveria de ser diferente.

A verve positivista nasceu como uma ideologia do capitalismo, ainda incipiente, porém cada vez mais consolidado como proposta de gestão do poder social. Assim, afirma ZAFFARONI \&

\footnotetext{
${ }^{15}$ Rivera Beiras. Op. cit. p.55.

${ }^{16}$ Idem. Ibidem.
} 
PIERANGELI ${ }^{17}$ que com a consolidação do capitalismo nos espaços urbanos, "é suficientemente lógico que o organicismo social se tornasse mais radical e, ao mesmo tempo, escondesse sua natureza eminentemente idealista sob o disfarce de um realismo supostamente evidente".

As artimanhas de dominação utilizadas pelo capitalismo penetraram nos mais variados campos do saber, e no contexto criminal a pretensão era a de capturar as razões ou a etiologia da conduta criminal tendo em vista o papel exercido pela personalidade do infrator, estabelecendo como justificativa a busca de uma explicação científica para a criminalidade ${ }^{18}$.

Diante deste quadro, fazia todo o sentido buscar distinções funcionais no comportamento desviante, a fim de acentuar a sua gravidade e o seu risco para a sobrevivência dos demais integrantes da sociedade. O crime passou então a ser concebido muito mais como uma violação à coletividade, ao contrato que estaria na base da sociabilidade, do que propriamente como um dano circunscrito à esfera da vítima ${ }^{19}$. Nascia a criminologia científica ou positiva ${ }^{20}$.

ÉMILE DURKHEIM, em 1897, já afirmava que "a criminologia estava na moda" "21. Na verdade, quis antever o sociólogo francês que o método interdisciplinar lançado pela criminologia o estava, na medida em que havia superado abordagens meramente situacionais e contidas em

${ }^{17}$ Op. cit. p. 294.

${ }^{18}$ Rivera Beiras. Op. cit. p.55.

${ }^{19}$ A criminologia positivista, como bem captado por Teresa Miralles (apud, Rivera Beiras. Op.cit.p.55), partiu do "pressuposto básico do caráter singular e distinto do comportamento delinqüente em relação ao comportamento adaptado às normas sociais e jurídicas. E ainda mais, nesta origem singular do comportamento delinqüente está implícita uma base patológica do indivíduo que o leva a cabo".

${ }^{20}$ Foi Rafael Garófalo, um dos discípulos de Lombroso, que inaugura o termo criminologia ao publicar em 1885 a primeira edição de sua obra denominada "Criminologia". Ao que se pode investigar, a primeira vez que Lombroso utilizou esta palavra foi em 1889, na quarta edição de O homem delinqüente, quando fala do “criminólogo". (Cf. Carlos María Landecho, S.J. La tipificación Lombrosiana de delicuentes. Tomo I. Madrid: Universidad Nacional de Educación a Distancia, 2004, p.59, nota n.4). Outros autores concordam que o impulso inicial da criminologia não coube a Lombroso, apesar de reconhecerem nele o seu mais expoente representante nos primórdios da disciplina. Assim saliente Salomão Shecaira (Op. cit, p. 74) que o antropólogo Topinard, em 1879, empregou pela primeira vez a palavra "criminologia", ao passo que Raffaele Garófalo a utilizou como título de seu livro em 1885. "Dentro deste contexto, diminui, em parte, o protagonismo precursor de Lombroso".

${ }^{21}$ Apud Landecho. Op. cit, p.35 
campos específicos do saber. O que a criminologia fornecia de novo na compreensão do fenômeno criminal era a sua aproximação multifacetada e complexa, ao menos em tese.

A criminologia positiva nasce, por assim dizer, herdeira de uma abordagem causalista e experimental e, portanto, pronta a projetar seus problemas na direção das causas do crime. E coube a Cesare Lombroso, por meio de sua conhecida obra O Homem Delinquente, consolidar a abordagem positivista no cenário criminológico através de uma linguagem acessível, mensurável e descomplicada do fenômeno criminal. A primeira edição do livro foi concluída por LOMBROSO no primeiro dia do ano de 1876, e sua obra de maior expressão veio definitivamente publicada em 15 de abril do mesmo ano ${ }^{22}$.

Logo, não tardou em penetrar nas mais variadas esferas sociais, seja entre os que a aclamaram ou os que duramente a criticaram ${ }^{23}$. De qualquer maneira, não se pode deixar de reconhecer o mérito de LOMBROSO em fazer-se conhecido por meio das conclusões apresentadas em seu escrito $^{24}$. Assim, por mais censuras que se possam levantar contra o pensamento positivista no campo criminológico, há de se reconhecer que a consolidação da criminologia, e para muitos o seu nascimento, foi um desdobramento das investigações empreendidas por CESARE Lombroso. Sobre esta questão, Alfonso SERrano Maíllo escreveu as seguintes palavras na apresentação da obra de CARLOS MARIA LANDECHO ${ }^{25}$ :

${ }^{22}$ Idem. Ididem, p. 173

${ }^{23} \mathrm{Na}$ origem, as idéias produzidas pela antropologia, em especial a de viés criminal, se revestiram de uma ótima proposta de justificação para os empreendimentos colonialistas do século XIX, que favorecia tanto as potencias tradicionalmente dominantes como outras que passaram a se interessar por este "negócio", como a Alemanha, a Bélgica e a Itália. (Cf. Zaffaroni \& Pierangeli. Op. cit, p.296)

${ }^{24}$ Em defesa de Lombroso escreveu Teodolindo Castiglione (Lombroso perante a criminologia. São Paulo: Saraiva, 1962, p.13): "O que, entretanto, surpreende não são as deficiências e as imperfeições das estatísticas, mas o que, através das estatísticas deficientes e imperfeitas, Lombroso tenha visto ou entrevisto de verdadeiro. Assim, tais estatísticas não impediram que ele se distanciasse da estrada batida e árida, que estudava o crime, como que fazendo abstração da personalidade do criminoso, e inaugurasse, com a firmeza de sua doutrina, uma nova era, a era em que o criminoso é a figura central, o elemento básico da criminologia dos nossos dias".

${ }^{25}$ Landecho. Op. cit, p.36. O mesmo autor, em outro ponto de seu texto de apresentação da obra mencionada, salienta que o ensinamento mais importante deixado por Lombroso e advindo desde a primeira edição de $O$ homem delinquente, se deu em relação as tipologias por ele estabelecidas para estudar o delito, e isto continua sendo "a fundamentação mais importante e característica da criminologia contemporânea" (Idem. Ibidem, p.37). 


\begin{abstract}
"o recurso ao método científico para o estudo do comportamento humano, e mais concretamente para uma forma especialmente complexa e difícil de entender intuitivamente como é o comportamento delitivo, constitui provavelmente o ensinamento mais importante de Lombroso e de sua escola à criminologia".
\end{abstract}

\begin{abstract}
Avançando um pouco mais em direção aos meandros criminológicos da escola positiva italiana, conta ROBERTO LYRA que ao autopsiar no ano de 1869 o cadáver de Vilela, conhecido criminoso milanês, teria LOMBROSO encontrado na base do crânio daquele a fossa occiptal média, estrutura que revelaria àquela altura a relação entre o instinto criminoso e a regressão atávica, por se tratar de uma estrutura considerada como um resquício vestigial ${ }^{26}$.
\end{abstract}

Outrossim, após examinar mais de 380 crânios de criminosos italianos, LOMBROSO não voltou a encontrar tal estrutura em nenhum deles ${ }^{27}$, e ainda assim não mais abandonou a tese do

Sobre esta obra, vale destacar que se trata de importante referência a todos que pretendem aprofundar as nuances do pensamento e da obra de Cesare Lombroso, pois que apresenta um retrato ampliado, e ao mesmo tempo pormenorizado, captado com riqueza de detalhes, do pensamento lombrosiano. Desde a trajetória humana, passando pela formação da teoria e pela construção da doutrina de Lombroso, a obra de Landecho expõe questões pouco afeitas aos trabalhos sobre aquele que por muitos é considerado o pai da criminologia. Também é estudada pelo autor o processo de gênese da Magna obra de Lombroso, "O Homem Delinquente", retratando as características de cada uma das edições e revisões pelos quais o pensamento do mestre de Turim passou, os possíveis volumes fantasmas atribuídos ao livro, o problema das traduções da obra e suas posteriores interpretações e, por fim, as consequiências da doutrina lançada por Lombroso e a sua recepção às críticas, especialmente no campo da sociologia criminal. Outro importante trabalho sobre a obra de Lombroso, especialmente no tocante ao estudo da embriologia do crime na visão do médico italiano, foi escrito por JeanMichel Labadie (Les mots du crime - approuche épistémologique de quelques discours sur le criminel. Montreal/Otawa: De Boeck Université, S.D, p.119-163).

${ }^{26}$ De acordo com o Dicionário Eletrônico Houaiss (2001), por resquício vestigial se entende um pequeno fragmento ou resíduo de estrutura ou órgão atrofiado e não funcional de um animal, que em seus ancestrais apresentava-se bem desenvolvido e com funções específicas.

${ }^{27}$ Lyra, Roberto; Araújo Jr., João Marcello. Criminologia. $4^{a}$ Ed. Rio de Janeiro: Forense, 1995, p.40. E prosseguem os autores afirmando que: "A princípio, Lombroso avaliou em 65 a $70 \%$ os criminosos portadores do tipo criminal, reduzindo-os depois de 30 a 35\% e somente em crimes gravíssimos". (Op. cit, p.41). 
atavismo e da degenerescência biológica do criminoso enquanto bandeiras de seu pensamento $^{28}$.

A grande preocupação científica do positivismo criminológico, como já dito, estava na análise dos motivos pelos quais os sujeitos cometiam crimes, ou seja, centrava sua atenção na busca das causas da criminalidade. Apesar de a criminologia científica nascida pelas mãos de LOMBROSO haver se preocupado com outros fatores, tais como os psicológicos e os sociais, é correto o entendimento de que sua análise estava centrava num rígido determinismo biológico como causa principal do comportamento criminal $^{29}$. E esta construção ficou conhecida como a doutrina do criminoso nato ${ }^{30}$.

Cesare Lombroso foi o mais expoente defensor da idéia de que o criminoso não se faz, mas nasce delinquente, e isso facilitava a distinção entre estes e os não delinqüentes por um conjunto de traços estigmatizantes, tanto de natureza física quanto anímica. Ao estudar a interface entre a delinquência e a personalidade, bem depois de LOMBROSO, H.EYSENCK professou a seguinte reflexão histórica:

${ }^{28}$ Conforme expressa Teodolindo Castiglione (Op. cit, p. 223), a fundamental importância de Lombroso não se deu com suas associações no campo do atavismo, na degeneração ou na questão da epilepsia, mas o ganho proposto pelo médico veronês estava na afirmação acerca da existência de causas biológicas que levariam a prática de condutas criminosas. Em última análise, Lombroso contribuiu quando jogou luzes no potencial destrutivo da personalidade humana.

${ }^{29}$ Rivera Beiras. Op. cit, p.56.

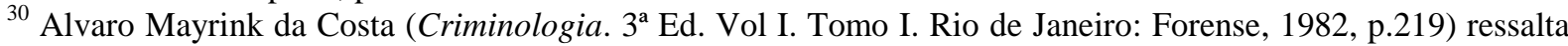
que "não é verdadeiro que a antropologia criminal tenha reconhecido nos fatores individuais a causa única do delito, bem como atribuir a Lombroso a expressão vulgar delinquente-nato, tal expressão se deve a Ferri, quando publicou uma crônica sobre a obra de Lombroso, a fim de dar um significado ao tipo por ele descrito". Também em A. Baratta é possível encontrar o reconhecimento de que a visão antropológica de Lombroso, que não negligenciava os fatores psicológicos e sociais, seria mais tarde ampliada por Rafael Garófalo, com a inserção dos fatores psicológicos e por Enrico Ferri, com a acentuação dos fatores sociológicos (Baratta. Op. cit, p.39). Apesar de discípulos e propagadores das idéias de Lombroso, Ferri e Garófalo cumpriram papéis diversos, ainda que complementares, na difusão das idéias positivistas no seio criminológico. Um estudo mais acurado dos próceres da criminologia pode ser encontrada diretamente nas obras de Enrico Ferri (Princípios de direito criminal: o criminoso e o crime. $2^{\mathrm{a}}$ ed. Trad. Paolo Capitanio. Campinas: Bookseller, 2003) e Raffaele Garófalo (La criminología. Estudio sobre el delito y sobre la teoría de la repression. Montevideo/Buenos Aires: Editorial Bdef, 2005). Para uma abordagem acerca das principais diferenças entre o pensamento de Ferri e de Garófalo, que foram os mais destacados seguidores de Lombroso, Cf. Debuyst, Christian; Digneffe, Fronçoise; Pires, Alvaro P. Histoire des saviors sur le crime \& la peine. Vol. II. Montreal/Otawa: De Boeck Université, S.D, p.269-298. 
"Uma das crenças que muita gente tem professado sobre a delinqüência ao longo da história é que os delitos são perpetrados por delinqüentes natos, é dizer, pessoas que desde seu nascimento estavam vocacionadas a isto. Não se dão influências do entorno, que condicionem os atos do delinqüente. Simplesmente, o delinqüente é 'mal desde que nasce'. Portanto, seja qual for a sociedade em que vivam, essas pessoas sempre realizarão atos delitivos. Levam inscrita, por assim dizer, a marca de Caim".

O homem delinquente estaria sempre pronto a atacar, a infringir as regras sociais e a impor sofrimento aos seus semelhantes, exatamente por ser herdeiro de um impulso criminoso que lhe seria inato, tal como uma marca tatuada em sua carne. Portanto, haveria de ser temido, seja pelo perigo real que representava, seja pela história de sangue que carregava. Um concentrado de miséria humana, um degenerado social, não poderia comungar dos ganhos da civilização, não poderia sentar à mesa dos eleitos para partilhar o banquete junto aos homens de bens. Neste sentido, afirmou T. CASTIGLIONE ${ }^{31}$ :

"Repetiu-se muitas vezes, com a mais variada linguagem, que, nos componentes de uma sociedade, há dois seres: um individual; outro, social; dois seres que, no homem comum, geralmente se harmonizam, e, no criminoso, com inúmeras graduações, geralmente se chocam.”

E a principal razão deste temor repousava num traço de comportamento desenvolvido exclusivamente nestes malditos homens, conhecido pela criminologia como atavismo. Se a

${ }^{31}$ Castiglione. Op. cit, p. 99. 
sombra de Caim foi capaz de atravessar o tempo e penetrar nas mais variadas manifestações culturais, a prova estava consolidada nos "filhos" que, de forma atemporal, teria ele deixado.

E foi assim que a evocação a Caim, mesmo que mencionada de forma expressa nos escritos dos próceres da criminologia, passou a legitimar as medidas de segregação propostas pelo positivismo, sempre orientadas pelo nobre interesse de proteger "os filhos de Abel". Assim, o crime passaria a ser concebido como um embate de forças do bem contra o mal, numa guerra que tudo justificaria para debelar o perigo do atavismo ${ }^{32}$.

O atavismo, tal como preconizado por CESARE LOMBROSO, aceitava como válida a assertiva de que um grupo de indivíduos, tidos como transgressores da ordem, representava o resultado de uma evolução às avessas. Assim, as ilegalidades praticadas por eles eram consideradas manifestações do primitivismo e da selvageria que lhes eram próprias, isto é, marcas de Caim $^{33}$.

\footnotetext{
${ }^{32}$ A história do cristianismo, narrada na Bíblia Sagrada no Livro de Gênesis, informa que Adão e Eva tiveram dois filhos: Caim e Abel. Abel era pastor de ovelhas e Caim lavrador. Ambos ofereceram sacrifícios ao Senhor. "Caim deu frutos das suas terras e Abel os melhores cordeiros do seu rebanho. O Senhor viu com prazer o sacrifício de Abel, mas não olhou para a oferenda de Caim. Este ficou muito irritado. O Senhor disse-lhe: 'Por que estás irritado? Se praticares o bem serás recompensado, mas se fizeres o mal serás castigado. Domina as tuas paixões'. Depois disto, Caim disse a seu irmão: 'Saiamos'. E, logo que estavam no campo, Caim lançou-se contra seu Abel e cona o matou". (In < http://www.bibliacatolica.com.br/historia_biblia/7.php\#ixzz1IOFXP0oU> Acessado em 01.04.2011. Também Rogério Greco (Curso de direito penal. Vol II. Rio de Janeiro: Impetus, 2010, p.130), ao analisar o crime de homicídio destaca aquele que foi o primeiro assassinato da humanidade: "A Bíblia nos relata a história do primeiro homicídio, cometido por Caim contra seu irmão Abel, em Gênesis, Capítulo 4, versículo 8. Caim agiu impelido por um sentimento de inveja, pois Deus havia se agradado da oferta trazida pelo seu irmão Abel e rejeitado a dele."

${ }_{33}$ Ao lado das passagens bíblicas versando sobre a história de Caim, há uma série de interpretações acerca da origem e dos sinais deixados em Caim decorrentes do seu ato contra Abel. A semente da serpente, por exemplo, é uma doutrina religiosa segundo a qual o pecado original teria decorrido de um ato sexual entre Eva e a serpente, simbolizada como Satanás, e não entre Eva e Adão. Desta relação teria nascido o primogênito, Caim, surgindo uma linha de descendência satânica a partir dele. Outra interpretação foi apresentada pela conhecida lenda dos vampiros de "A Máscara", famoso jogo de RPG da década de 90 do século $\mathrm{XX}$, sugerindo que o progenitor de todos os mortos-vivos foi Caim, o assassino bíblico de seu irmão, Abel, pois que teria sido amaldiçoado por Deus e condenado a caminhar eternamente sobre o mundo na forma de um vampiro condenado a beber sangue. Outra compreensão se deu especificamente em razão da marca deixada por Deus em Caim (No Livro de Gênesis, Cap. 4, versículos 14-15, Caim é interpelado por Deus para que confesse o paradeiro de Abel. Caim não relata expressamente o assassinato do irmão, mas demonstra temor para com as
} 
E o risco de transmissão deste mal, que se daria especialmente pela via hereditária, haveria de ser combatido com a exclusão social de seus desgraçados portadores. Do outro lado do corpo social, pousariam tranqüilos os felizes eleitos e bem sucedidos produtos da evolução humana, aqueles que não afrontam as leis, mas as respeitam de forma solidária. E esta divisão tão absurda quanto arbitrária serviu tão somente como um argumento a mais para justificar a dominação de uns sobre outros ${ }^{34}$.

A busca por um corpo doente para o criminoso, relacionando o crime à existência de inúmeras doenças como cardiopatias, transtornos neurológicos, sífilis, tuberculose, verminose, ou buscando associar o comportamento criminoso com alterações hormonais, representou a tônica do discurso criminológico nascido na transição do século XIX para o $\mathrm{XX}^{35}$.

HiPPOLYTE-ADOLPHE TAINE, expoente figura do positivismo francês na segunda metade do Séc. XIX, em correspondência remetida a Lombroso, no ano seguinte à publicação da primeira edição de L'Uomo Delinquente, externou sua admiração ao Professor de Turim por haver aproximado e conciliado a responsabilidade e o determinismo e, em especial menção, por haver apresentado aqueles que o antropólogo francês chamou de orangotangos lúbricos, "ferozes de face humana",36.

consequências de seu ato, especialmente a vingança que poderia sofrer, e sugere uma fuga. Ele teme por aquilo que suprimiu, a vida. Ao que Deus responde: "Não! Mas aquele que matar Caim será punido sete vezes." O Senhor pôs em Caim um sinal, para que, se alguém o encontrasse, não o matasse.), e que segundo alguns textos mórmons, o sinal estaria relacionado à cor da pele de Caim, o tornando pai da raça negra africana. Cf. <http://pt.wikipedia.org/wiki/Caim>. Acessado em 01.04.2011.

${ }^{34}$ Rauter, Cristina. Criminologia e subjetividade no Brasil. Rio de Janeiro: Revan/ICC, 2003, p.58-59.

${ }^{35}$ Idem. Ibidem, p. 39.

${ }^{36}$ Lombroso. Op. cit, p.19-20. Nos dizeres de Taine: "Se eles matam, é em virtude de seu natural e de seu passado, infalivelmente. Razão a mais para destruí-los logo que se constata que são e permanecerão sendo sempre orangotangos". 
Ao lado do atavismo ${ }^{37}$, que nas palavras de R. LYRA 38 "foi a base principal das hipóteses de Lombroso", outro dado fundamental referente à doutrina do criminoso nato foi o estudo do aspecto fisionômico ostentado pelos "filhos de Caim". Apesar de o próprio LomBroso asseverar que sua teoria não se nutria apenas com os estudos da fisionomia, muito da repercussão de sua obra deveu-se a este fator. Assim afirmou que:

“(...) não são apenas os caracteres fisionômicos (que às vezes podem faltar), mas os biológicos e os funcionais, que apreciamos no criminoso nato. Ora, esses últimos caracteres não faltam quase nunca no verdadeiro criminoso: por exemplo, o mancinismo, as anomalias do reflexo e da sensibilidade."39

Ao comentar as características anatômicas e os desdobramentos psicológicos atribuídos por Lombroso ao criminoso nato, SEELIG destacou que o professor de Turim não pretendeu aplicar esta idéia, indistintamente, a todos os transgressores da lei penal, mas que grande parte deles subtraía a atenção de LOMBROSO exatamente por se enquadrar nos critérios definidos pela doutrina do tipo nato. Assim,

“(...) como nem toda a gente que entra em conflito com a lei penal mostra estas características (como o próprio Lombroso reconheceu) ele distinguiu, mais tarde, como 'criminosos ocasionais' e 'passionais', mantendo-se porém agarrado à idéia de que a maior parte restante dos criminosos

\footnotetext{
${ }^{37}$ Garcia Páblos de Molina apresentou as ligações entre o atavismo e outros temas importantes à concepção que, ele mesmo, denominou de "mito lombrosiano" (Op. cit. p. 179 et seq): "Em sua teoria da criminalidade Lombroso inter-relaciona o atavismo, a loucura moral e a epilepsia: o criminoso nato é um ser inferior, atávico, que não evoluiu, igual a uma criança ou um loco moral, que ainda necessita de uma abertura ao mundo dos valores; é um indivíduo que, ademais, sofre alguma forma de epilepsia, com suas correspondentes lesões cerebrais". (Ibidem, p.190)

${ }_{39}^{38}$ Lyra, et al. Op. cit, p. 41.

${ }^{39}$ Lombroso, Cesare. O homem delinquente. Trad. Maristela Blegi Tomasini e Oscar Antonio Corbo Garcia. Porto Alegre: Ricardo Lenz, 2001, p.32. Por mancinismo entende-se a "disposição natural para o uso da parte esquerda do corpo". (Dicionário Houaiss. Versão Eletrônica. 2001)
} 
formavam um tipo antropológico unitário: o criminoso verdadeiro nasce como tal, a sociedade dá-lhe apenas as possibilidades e motivos para a manifestação de sua disposição criminosa."40

Outro suporte para a teoria lombrosiana foi a estatística, que mesmo rudimentar ali se prestava para revestir de cientificidade suas observações e para blindá-las de uma áurea de neutralidade e inquestionabilidade. A importância das cifras, dos cálculos e das estatísticas criminais foi lembrada por LOMBROSO “(...) porque foi assim, em deixando de lado o desnecessário, em calculando tudo o que se pode calcular, para triunfo do número e do metro, que nossa era científica ultrapassou as precedentes". 41

Em defesa de Lombroso escreveu TEODOLindo CASTIGLIONE:

"O que, entretanto, surpreende não são as deficiências e as imperfeições das estatísticas, mas o que, através das estatísticas deficientes e imperfeitas, Lombroso tenha visto ou entrevisto de verdadeiro. Assim, tais estatísticas não impediram que ele se distanciasse da estrada batida e árida, que estudava o crime, como que fazendo abstração da personalidade do criminoso, e inaugurasse, com a

\footnotetext{
${ }^{40}$ Seelig, Ernst. Manual de criminologia. Vol. I. Trad. Guilherme de Oliveira. Coimbra: Arménio Amado Editor, 1957, p. 45.

${ }^{41}$ Lombroso. Op. cit, p. 39. Alfonso Serrano Maíllo (Op. cit, p.69) traz importante contribuição a respeito do papel da estatística criminal no desabrochar da criminologia: "As estatísticas oficiais são um instrumento hoje habitual que nasceu com o Estado moderno. Este necessita realizar medições para organizar-se de forma racional; por exemplo, necessita saber quantos habitantes tem para estabelecer exércitos permanentes, a distribuição das rendas e a produção para a organização da fazenda...Em 1827 foram publicadas na França as primeiras estatísticas modernas sobre a delinqüência. As primeiras estatísticas atraíram a atenção de investigadores importantes, entre eles Guerry e, sobretudo, Quetelet. Esses autores, que ocupam lugar de honra na Criminologia, inscrevem-se no chamado movimento da estatística moral, que precisamente se refere ao objetivo de realizar medições relativas ao comportamrnto humano - ou seja, os assuntos morais -, seguindo o método que as ciências aplicavam aos fenômenos naturais. Assim, também Quetelet, como quase todos os importantes precursores da Criminologia contemporânea que estudamos neste Capítulo, dá um impulso decisivo para que o método cientifico seja aplicado ao comportamento humano".
} 
firmeza de sua doutrina, uma nova era, a era em que o criminoso é a figura central, o elemento básico da criminologia dos nossos dias." ${ }^{42}$

LANDECHO apresenta uma reflexão mais realista do aspecto analítico de LOMBROSO, sobretudo no trato com os dados empíricos por ele colhidos e a transmudação deles para a seara estatística. Com base nisso conclui que

"A vertente científica de Lombroso reflete o seu perfil humano: Lombroso é um investigador intuitivo quase genial, porém carente da capacidade de analisar e criticar os materiais que elabora (...). Por isso, Lombroso não é um investigador positivo que ele próprio sonhou, senão que um poeta da ciência."43

De todo o exposto, cuja finalidade estava em apresentar, ainda que em linhas gerais, uma síntese dos aportes lombrosianos, fica uma certeza lembrada por ANTONIO GÁRCIA-PABLOS DE MOLINA de que "o positivismo criminológico professa uma concepção classista e discriminatória da ordem social, imbuída de preconceitos e de acordo com o mito da "diversidade" do delinquente" $"$.

O positivismo criminológico consolidou um processo de mudança nos mecanismos de punição social, em especial quanto ao cárcere. Se séculos antes das elaborações doutrinárias

\footnotetext{
${ }^{42}$ Castiglione. Op. cit, p. 13. Em defesa de Lombroso, escreveu Serrano Maíllo no prefácio da obra de Landecho (Op. cit, p.40): "O problema fundamental de Lombroso foi que em seu tempo não havia à sua disposição todo o desenvolvimento da estatística, que, se utilizada da forma correta, constitui uma ferramenta imprescindível para a análise de dados em casos como o que ele enfrentou".

${ }^{43}$ Landecho. Op. cit, p.165. Assim, as intuições de Lombroso chegavam a obsoletar sua análise e, especialmente, sua autocrítica (Landecho, p.299). Num outro trecho, arremata o autor: "Lombroso cita toda classe de causas (algumas com pouca coesão interna e sem clara conexão entre si), sem que prove suficientemente que alguma delas seja motivação dos fenômenos que analisa. Somente se limita a enumerar exemplos e estatísticas, com grupos de prova excessivamente pequenos, e sem estabelecer grupos de controle que pudessem fornecer o valor das porcentagens que se manejam em seu estudo sobre as citadas causas."( Landecho, p.667)

${ }^{44}$ Molina. Op. cit, p. 188.
} 
lombrosianas o cárcere se revestia de instrumento acautelatório para a punição corporal ${ }^{45}$, com o advento das idéias clássicas e, sobretudo, do frisson positivista, a prisão não apenas se tornaria o mecanismo de punição social por excelência como também haveria de se prestar a corrigir, doutrinar e domesticar aqueles que não demonstravam aptidão para a sociabilidade ${ }^{46}$.

E foi assim que o discurso positivista, sedutor pela sua clareza e eficaz pela apresentação de respostas de fácil apreensão popular, foi caminhando do debate científico para as cadeiras do poder, assumindo as plataformas político-criminais de inúmeros governos e se transformando no modelo criminológico Oficial.

Foi este o cenário que propiciou um conjunto de propostas tendentes a separar a determinação da culpa decorrente de um crime e a posterior imposição de pena: a primeira haveria de ser uma tarefa para o direito, ao passo que a segunda ficaria à cargo dos baluartes de uma forma de medicina social ${ }^{47}$.

Em suma, o pensamento positivista deixou um legado que pode ser notado, ainda hoje, e pode ser traduzido na máxima tentativa de aniquilamento da diferença, na busca de promover a massificação da sociedade em prol da produção e do capital. Não se está negando com isso os ganhos acadêmicos decorrentes das considerações positivistas, eis que isso incorreria num grave erro de desqualificar por completo o trabalho de um número imensurável de pesquisadores de ontem e de hoje.

\footnotetext{
${ }^{45}$ Vale lembrar a regra inserida pelo Imperador Justiniano no Digesto (In. Rusche, Georg; Kirchheimer, Otto. Punição e estrutura social. Trad. Gizlene Neder. 2 ed. Rio de Janeiro: Revan, 2004, p. 94). : "Carcer enim ad continendos homines non ad puniendos haberi debet (As prisões existem apenas para prender os homens e não para puni-los)".

${ }^{46}$ Com base na criminologia psicanalítica, e seguindo o tributo positivista, Alexander e Staub (Apud. Dias, José de Figueiredo; Andrade, Manuel da Costa. Criminologia. O homem delinqüente e a sociedade criminógena. $2^{\mathrm{a}}$ reimpressão. Coimbra: Coimbra Editora, 1997, p. 206) preconizam o seguinte ao criminoso de sintoma neurótico: "Se é curável, deve internar-se para fins de tratamento psiquiátrico, internamento que deve durar enquanto o criminoso constituir um perigo para a sociedade. Se é incurável, é preciso interná-lo, por toda a vida, num hospital destinado a incuráveis."

${ }^{47}$ Rusche \& Kirchheimer. Op. cit, p. 200.
} 
O que se quer apontar é que a teoria aparentemente asséptica acarretou resultados desastrosos na práxis, resultados esses a que a própria teoria assumiu o risco de patrocinar. A "escola reformista"48 não só responde pela paternidade (ou fundamento criminológico) do recurso indiscriminado ao encarceramento como forma de profilaxia criminal quanto, e também lhe cabe a referência, de que o cárcere deve ser o mais aviltante possível na sua empreitada de curar os doentes, endireitar os errantes e vacinar os tergiversantes.

\subsubsection{O positivismo criminológico e seu legado para o cárcere}

Analisando as modalidades de punição que seriam devidas a tipos específicos de criminosos, disse LOMBROSO:

"Para os criminosos de ocasião, conformo-me com a esfera das leis comuns e contento-me em reclamar seu alcance a métodos preventivos. Quanto aos criminosos natos e loucos morais, as mudanças propostas por mim não fariam senão aumentar a segurança social, pois reclamo, para eles, uma detenção perpétua. (...) Há séculos já que o povo sinalou a incorrigibilidade dos culpados, sobretudo dos ladrões, e a inutilidade das prisões." 49

E na sequência, o próprio LOMBROSO cita aplicações de sua teoria que já eram, antes mesmo de seus estudos, postas em prática na sociedade: "Valério e Loyseau citam um édito medieval

\footnotetext{
${ }^{48}$ Idem, p. 207.

${ }^{49}$ Lombroso. Op. cit, p. 28. Em outro ponto de seu prefácio, Lombroso faz questão de registrar que não centraliza sua teoria na figura do delinqüente nato, apesar de preferir "o tipo lombrosiano" aos demais no cerne de seus estudos, e reconhece, se referindo a ele e a seus seguidores, que "(...) nós mesmos admitimos, ao lado dos criminosos natos, os criminosos de ocasião e os criminosos por paixão que não são degenerados." (Op. cit, p.36).
} 
prescrevendo: no caso de dois indivíduos serem suspeitos, aplica-se a tortura ao mais feio dos dois." $" 50$

Da doutrina do criminoso nato, LOMBRoso extraiu importantes conclusões no campo na política criminal. Contra este tipo de opositor da norma penal, em razão de sua patologia social conferida pelo indomável impulso criminal, não caberiam punições de caráter moral ou infamante, pois antes de se projetar como um risco a sociedade, tal sujeito representava um risco a si próprio, e por isso haveria de merecer punições perpétuas e até mesmo a pena capital $^{51}$.

Ao centrar seus estudos na figura do delinqüente nato, posteriormente denominado de tipo lombrosiano, o pai da criminologia e seus seguidores acabaram disseminando seus caracteres, ainda que de forma menos intensa, para os outros tipos de criminosos que reconheceram. Assim, como afirmava LANDECHO,

"Lombroso pensa que o delinqüente ocasional também possui uma tendência congênita, ainda que de mínima intensidade. Todavia, os fatores exógenos, especialmente a repetição dos atos delitivos,

\footnotetext{
${ }^{50}$ Ididem. p. 28. Esta afirmação apresenta decisiva contribuição da orientação empírica denominada fisionomia, que nascida pelas mãos de Della Porta e Lavater, tinha a preocupação de estudar a aparência externa do indivíduo a fim de acentuar a relação entre o somático (corpo) e o psíquico. As observações realizadas pelos autores ocorriam em presídios e necrotérios. Como ressaltou Molina (Op. cit, p. 177-178), "particularmente conhecido é o 'retrato robô' que ofereceu Lavater, denominado 'homem de maldade natural', baseado nas suas supostas características somáticas. E, na práxis, o conhecido 'Édito de Valério' (quando se tem dúvida entre dois presumidos culpados, condena-se o mais feio) ou a forma processual que, ao que parece, foi imposta no século XVIII por um juiz napolitano, o marques de Moscardi ('ouvidas as testemunhas de acusação e de defesa e visto o rosto e a cabeça do acusado, condeno-o...'), que se vinculam a tais concepções fisionômicas, de escasso rigor teórico-científico, porém com grande apoio nas convicções populares e na práxis criminológica".

${ }^{51}$ Seelig. Op. cit, p. 45. A adoção da pena capital não era tolerada indistintamente por todos os positivistas, havendo dentro do círculo mais próximo a Lombroso quem rejeitasse esta hipótese, como, por exemplo, Ferri (Op.cit, p.238-239). Sobre a divergência entre Ferri e Garófalo à respeito da pena de morte, remetemos à leitura de Debuyst (Op. cit, p. 276-278). O autor expõe a opção de Garófalo pela admissão da pena de morte, trazendo à lume os argumentos do criminólogo italiano para a defesa de sua posição, ao mesmo tempo em que expõe as razões que faziam de Ferri um opositor desta modalidade de pena.
} 
poderiam convertê-lo paulatinamente em delinqüente habitual que, em seu estado final, não mais se distinguiria em seu perfil externo do delinqüente nato, pois teria arraigado pelo hábito a mesma tendência criminosa que o nato teria congênita". 52

As idéias do positivismo, por mais que buscassem diversificar seus postulados para agregar outros argumentos que não os de índole essencialmente médico-psiquiátrica, inserindo aspectos sociais $^{53}$ e até mesmo fundamentos jurídicos em seu discurso, nunca conseguiram fazê-lo de forma convincente ${ }^{54}$. Foi assim com LOMBROSO, que era médico e, como tal, já orientava seus estudos por este viés, e também com outras importantes vozes da criminologia que sorveram avidamente o discurso clínico.

${ }^{52}$ Landecho. Op. cit, p. 653. No mesmo sentido afirmava Ferri (Princípios..., p.232): "Se qualquer crime, do mais leve ao mais feroz, é a expressão sintomática de uma personalidade anti-social, que é sempre mais ou menos anormal e portanto mais ou menos perigosa, é inevitável a conclusão de que a organização jurídica da defesa social repressiva não se pode subordinar a uma pretensa normalidade ou intimidabilidade ou dirigibilidade do delinquente. De qualquer maneira que um homem se torne delinqüente, com vontade e inteligência aparentemente normais, em virtude de pouca anormalidade, ou com vontade e inteligência fracas ou anormais ou doentes, incumbe sempre ao Estado a necessidade - e portanto o direito-dever - da defesa repressiva, somente subrodinada, na forma e na medidad das suas sanções, à personalidade de cada delinqüente, mais ou menos readaptável à vida social".

${ }^{53}$ Uma visão pretensamente social, sempre nos moldes dos discursos positivistas, veio expressa por Lacassagne (Apud, Araújo, Cláudio Theotonio; Menezes, Marco Antonio de. Execução penal, exame criminológico e apreciação dos indicadores de potencial criminógeno. In: Rigonatti, Sérgio Paulo (Org.). Temas em psiquiatria forense e psicologia jurídica. São Paulo: Vetro, 2003. p. 243-244), que afirmava: "A sociedade tem os criminosos que merece. A sociedade é o caldo de cultura da criminalidade; o micróbio é o criminosos, que não tem importância, senão quando encontra o caldo que o faz fomentar." Também Ferri (Apud, Ribeiro, Bruno de Morais. A função de reintegração social da pena privativa de liberdade. Porto Alegre: Sergio Antonio Fabris, 2008. p.56) professou discurso à sombra de Lacassagne, quando afirmava que o cárcere era como "estufa para o cultivo dos micróbios criminais".

${ }^{54}$ Exemplo disso se deu na intensa batalha travada em torno da questão da responsabilidade do delinqüente perante a sociedade e o Estado. A discussão não raro ultrapassava o terreno jurídico para repousar nas tranqüilizadoras razões de jaez psiquiátrico que, em essência, representavam o susbtrato teórico do conceito de responsabilidade social, levantada pela criminologia positivista contra a alegada responsabilidade moral apresentada pela criminologia clássica. Sobre isso afirmou Ferri (Op. cit, p. 231): "A Escola Positiva, substituindo por meu intermédio, logo no início, o critério de 'responsabilidade social' ao de 'responsabilidade moral', deu uma solução ao problema da responsabilidade humana, que se pode aceitar ou não, mas que é certamente lógica e consequente como o era a da Escola Clássica pura. Com a única diferença de que a solução positivista é tirada da observação palpitante da realidade humana com os estudos acerca do homem delinqüente, enquanto que a solução clássica foi tirada somente da lógica abstrata, ignorante de como seja realmente formado o homem criminoso". 
A doutrina do criminoso nato não passou incólume pelo terreno das críticas, chegando a ser questionada por meio de estudos de campo que pretendiam averiguar as observações que lhe davam suporte. Neste sentido, o médico alemão Baer realizou inúmeras observações em cadeias de Berlim, concluindo que os seus ocupantes em quase nada se diferenciavam da população não criminosa, seja por sinais característicos ou particulares, e que tal ausência de traços distintivos jogava por terra a idéia de uma variedade morfológica no ser humano consubstanciada no criminoso nato ${ }^{55}$.

Como se depreende, as idéias lançadas por LOMBROSO passaram a justificar uma variada gama de intervenção no campo criminal, a ponto de se poder afirmar que a essência de seus pressupostos sofreram uma importante expansão, vez que se em algum momento relataram outros tipos ao lado do criminoso nato, por certo tinham neste conteúdo a justificativa para preconizar a quase todos os criminosos semelhante tipo de intervenção penal.

DAVID ABRAHAMSEN ${ }^{56}$, conhecido psiquiatra norueguês radicado nos Estados Unidos, não hesitava em considerar que a grande maioria dos delitos era decorrente de sintomas típicos de personalidades desviadas ou psiquicamente anômalas ${ }^{57}$. O mesmo autor, escrevendo sobre a interface entre o direito penal e a criminologia asseverava que: "Quando o psiquiatra for nomeado pelo Estado para todos os casos que se apresentem perante os tribunais, ter-se-á realizado um grande progresso" ${ }^{, 58}$.

\footnotetext{
${ }^{55}$ Seelig, Ernst. Op. cit, p.45-46.

${ }_{57}$ Apud, Castiglione. Op. cit, p. 213-214.

${ }^{57}$ Como afirmado linhas acima, não apenas os profissionais da área médica forma tributários das idéias lançadas por Lombroso. Basta ressaltar que seus mais expoentes seguidores na Itália, Enrico Ferri e Raffaele Garófalo eram juristas. Ferri (Op. cit, p. 209-210), no mesmo sentido que Abrahamsen, afirmava: "A primeira e natural condição para que um homem se possa dizer, social e legalmente, delinquente, está nisto: que o crime ou delito por ele realizado seja a expressão genuína da sua personalidade".

${ }_{58}$ Castiglione. Op. cit, p. 214.
} 
Havia uma nítida pretensão de psiquiatrizar o crime a partir da medicalização do infrator. Com isso, a figura do médico, em geral, e do psiquiatra, em especial, ganhavam espaços e foro de imprescindibilidade na gestão dos ilegalismos perpetrados pelo sistema penal.

Daí o campo favorável para o germinar das mais variadas e ecléticas tipologias e classificações de delinqüentes. Ato que não surpreende, se considerado o fato de se tentar estabelecer com o homem uma mesma e semelhante forma de compreensão daquela estabelecida com as patologias, devidamente catalogadas e discriminadas em seus elementos diagnósticos. E foi assim que o cenário criminal se tornou uma representação da linguagem clínica e o cárcere, uma extensão do contexto hospitalar.

Esta diretriz que remetia à medicalização do crime foi confirmada no II Congresso Internacional de Criminologia, ocorrido no ano de 1950 em Paris. Entre os encaminhamentos do encontro, um destacava a imprescindibilidade do saber psiquiátrico para a compreensão da criminalidade, quando afirmava que "o exame bio-tipológico-psiquiátrico do delinquiente é indispensável e deve ser realizado em todos os casos antes do julgamento ou da sentença". 59

\footnotetext{
${ }^{59}$ Idem. Ididem. No mesmo sentido, Castiglioni cita alguns casos que retratam a questão, entre as pgs. 214 a 224 , tanto no âmbito internacional quanto local. Merecem destaque uma publicação do Jornal paulistano Folha de São Paulo, do dia 07 de abril de 1961, intitulada "Psiquiatras concluem: o médico é a chave na luta contra a criminalidade", além de uma proposta aprovada na I Conferência Pan-Americana de Criminologia, realizada em 1947 no Rio de Janeiro, cujo texto informava que "todo indivíduo em virtude de prisão preventiva deve ser submetido a um exame psiquiátrico para se eliminarem possíveis erros judiciários". Teodolindo Castiglione ainda retrata uma publicação da International Review of Criminal Policy (n.10, julho, 1956), descrevendo os encaminhamentos da reunião do Grupo Consultivo Europeu em matéria de prevenção do delito e tratamento do delinqüente, realizada no ano de 1956 em Genebra. Na ocasião foi aprovado o seguinte programa: "O tratamento de determinados tipos de delinqüentes, a respeito dos quais a sociedade precisa de uma proteção especial: a) delinqüentes habituais; b) delinquentes anormais". No próprio texto publicado, como destaca o autor, foi explicitado que o termo delinquente habitual teria acepção ampla, e abarcaria "aqueles que, como os vagabundos e mendigos, levam um gênero de vida associal; os infratores habituais, por imprudência ou negligência; os delinquentes por tendência que não são multi-reincidentes".
} 
As tipologias francamente difundidas pela criminologia positiva, e utilizadas não raro de forma indiscriminada até os dias de hoje $\mathrm{e}^{60}$, se prestaram sobretudo a auxiliar na função curativa que a pena se dispunha a executar ${ }^{61}$. CASTIGLIONE destacou ainda mais esta nota clínica do discurso criminológico, abrindo a discussão acerca da modalidade de pena que mais foi preconizada por esta perspectiva: a medida de segurança.

"Quando se trata de um anormal que entra na órbita da psiquiatria, esta procura, de acordo com as suas possibilidades do momento, conhecer não uma normalidade abstrata, mas curar, remover as anormalidades que encontra a fim de transformar o delinquente no homem comum, esse que trabalha, luta, concorre para o bem coletivo e não infringe a lei penal". 62

A medida de segurança não necessita, para sua aplicação, de requisitos relativos à responsabilidade do agente, uma vez que sua pretensão se filtra na correção e propriamente na cura do infrator, além da preservação e sobrevivência da coletividade ${ }^{63}$, e nas palavras de ALESSANDRO BARATTA:

${ }^{60}$ Uma interessante investigação foi realizada por Bruno Shimizu (Um panorama crítico sobre o pensamento criminológico clínico no Brasil. In: Sá, Alvino Augusto; Tangerino, Davi de Paiva Costa; Shecaira, Sérgio Salomão. Criminologia no Brasil. História e aplicações clínicas e sociológicas. Rio de Janeiro: Elsevier, 2011), que fala, com exemplos muito significativos, do "fervor classificatório" exercido pela criminologia clínica e as pretensões de tal postura. $\mathrm{O}$ artigo, inclusive, realiza uma abordagem histórica acerca da recepção e evolução da clínica criminológica no Brasil.

${ }^{61}$ Baratta. Op. cit, p.40.

${ }^{62}$ Castiglione. Op. cit, p.221-222.

${ }^{63}$ Castiglione, Op. cit, p.198. Outra questão que surge como um desdobramento da medida de segurança é o tema da periculosidade. Sobre ele escreveu Castiglione (p.195): "Já se disse que, antes de Lombroso e da conseqüente escola positiva, o conhecimento embrionário da periculosidade do delinqüente e de medidas de segurança, não só existia em Atenas e Roma, como também na Ásia, séculos antes do cristianismo; mas foi a escola positiva, a despeito das reinvidicações do neo-classicismo, que deu vulto e consistência tanto à personalidade quanto às medidas de segurança.”. Tanto é assim que Ferri (Apud, Castiglione, p.195), ao prefaciar a tradução italiana da obra "A periculosidade" de Gimenez de Asúa, afirmou que 'a periculosidade do delinquente constitui o critério fundamental do novo rumo criminológico",. 
"A conseqüência politicamente tão discutível e discutida desta colocação é a duração tendencialmente indeterminada da pena, já que o critério de medição não está ligado abstratamente ao fato delituoso singular, ou seja, à violação do direito ou ao dano social produzido, mas às condições do sujeito tratado; e só em relação aos efeitos atribuídos à pena, melhoria e reeducação do delinquiente, pode ser medida sua duração."

Com todos os antecedentes citados, inclusive a adoção das medidas de segurança (não raro de caráter perpétuo), se pode entender que o positivismo encontrara nas instituições de sequestro perfeitos laboratórios para por em prova suas hipóteses ${ }^{65}$.

Neste cenário, a figura humana era objeto de uma dupla seleção: a primeira tendente a separar os degenerados dos sadios ${ }^{66}$, e a segunda, mais pontual, em identificar dentre os desgraçados aqueles que seriam verdadeiras feras humanas capazes de todo o mal. A estes, apenas a contenção perpétua seria útil para garantir a defesa da sociedade ou, se regeneráveis, a cura haveria de ser buscada. Nas palavras de FERRI ${ }^{67}$ "frente ao homem que está determinado ao delito, a sociedade está determinada a defender-se".

Nesta esteira, a pena, que passa a ser dirigida para domesticar os setores marginalizados, não tem outra medida que não a de "administrar" o perigo que o sujeito representa para uma parcela (os não degenerados) da sociedade. A mudança do nome do instrumento punitivo não

\footnotetext{
${ }^{64}$ Baratta. Op. cit, p.40.

${ }^{65}$ Beiras. Op. cit, p. 56.

${ }^{66}$ Como bem ressaltou Zaffaroni \& Pierangeli (Op. cit, p. 296), o grupo dominante, ou seja, os mais bem inseridos cultural e economicamente, estavam imunes às degenerescências biológicas, pois que sua "superioridade genética" os preservava. Assim, somente por acidente ou por uma infeliz circunstância um de seus membros poderia ser acometido pela pecha do crime.

${ }^{67}$ Apud, Zaffaroni \& Pierangeli. Op. cit, p. 298.
} 
seria em vão, pois agora passaria a ser utilizada a "pretensamente asséptica" medida de segurança ${ }^{68}$.

Neste horizonte, TERESA MIRALlEs ${ }^{69}$ aduz que o pressuposto básico erigido pelo positivismo criminológico estava em considerar como singular e distinto o comportamento delinqüente em comparação com aquele comportamento adaptado às normas sociais e jurídicas. E na origem deste comportamento desviado estaria uma base patológica que levaria o indivíduo a delinquir $^{70}$.

"O homem era uma coisa entre outras coisas, e existiam os de melhor e de pior qualidade. Os de pior qualidade, os 'degenerados' e biologicamente deficientes, caíam na escala social, por um processo de decantação 'natural', e deviam ser controlados pelos que se mantinham no poder, pois se convertiam em 'uma classe social perigosa'. O 'crime' era a manifestação de uma inferioridade, que nem sempre podia ser corrigida (em tal caso impunha-se eliminar ou segregar definitivamente o portador)."

O desenrolar da trama proposta pela criminologia positiva pretendia associar as características da conduta criminosa a elementos sintomáticos da personalidade de seu autor, dirigindo sobre este elemento as estratégias clínicas adequadas. De toda forma, impõe salientar, como bem captado por BARATTA ${ }^{72}$, que

\footnotetext{
${ }^{68}$ Ibidem, p.296. Esta "ideologia brutal", nas palavras de Zaffaroni, foi exportada para a América, e aqui foi apreciada por ditadores e por setores racistas das elites latinas, se prestando a justificar o desprezo pelos residentes mais comuns do cárcere, como o índio, o negro, o mestiço e o mulato. (p.296)

${ }^{69}$ Apud, Beiras. Op. cit, p.55.

${ }^{70}$ Sobre este aspecto, complementou Baratta (Op. cit, p. 39): "Esta orientação de pensamento buscava, de fato, a explicação da criminalidade na 'diversidade' ou anomalia dos autores de comportamentos criminalizados".

${ }^{71}$ Zaffaroni. Op. cit, p.296.

${ }^{72}$ Baratta. Op.cit, p.40.
} 
"os sujeitos que observava clinicamente para construir a teoria das causas da criminalidade eram indivíduos caídos na engrenagem judiciária e administrativa da justiça penal, sobretudo os clientes do cárcere e do manicômio judiciário, indivíduos selecionados daquele complexo sistema de filtros sucessivos que é o sistema penal."

Certo mesmo é que a única distinção que se pode fazer entre as condutas delitivas e as não delitivas é a de que as primeiras encontram-se proibidas em leis penais e, geralmente, violam costumes reconhecidos pela maioria da sociedade. A criminologia atual deve mirar outras preocupações que se distanciem dos enfoques etiológicos da criminalidade, que pouco contribuíram para a evolução deste saber, desde o ponto de vista explicativo ou no plano da intervenção voltada a reduzir as taxas de crime ${ }^{73}$.

Sobre este ponto, SAMENOW ${ }^{74}$ advertiu que:

"Durante a maior parte do século $\mathrm{XX}$, as teorias sobre o delito e os esforços para reduzí-lo se basearam em idéias acerca da causalidade. Os que apoiavam a tese ambientalista recomendaram mudanças no ambiente, tanto para o tratamento como para a prevenção de crimes. Alguns buscaram respostas na psicologia, crendo que deveria ser o indivíduo, antes que o ambiente, o objeto de interesse (...). E buscar as causas últimas do delito tem representado uma enorme perda de recursos. Com efeito, a sabedoria convencional, fundamentada nas causas, não consegue alterar a circunstância em que as prisões se avolumam e os cidadãos ficam reclusos em suas próprias casas”.

\footnotetext{
${ }^{73}$ Genovés. Genovés, Vicente Garrido. Técnicas de tratamiento para delincuentes. Madrid: Editorial Centro de Estudios Ramón Areces, s.d, p.17-18.

${ }^{74}$ Apud, Genovés. Idem, p.18.
} 
Parece que o texto acima quer indicar que a criminologia, da forma como tem direcionado seus estudos e, com eles, alimentado as políticas criminais, ao invés de compreender e controlar a criminalidade, tem, na verdade, assumido um papel de promoção e incremento do crime no cenário social.

Como bem ressaltou LYRA ${ }^{75}$, "Lombroso generalizou excessivamente. Ele atuou com exceções, isto é, os loucos, inclusive os loucos morais, que não são criminosos precisamente porque são loucos. O próprio conceito de normalidade é social”. E esta mesma generalização ocorrida na construção doutrinária acompanhou as políticas preconizadas à punição dos criminosos. Com Lombroso se exasperou a pena, na forma de medida de segurança, à imensa gama de criminosos tidos como anormais, seja na forma perpétua ou com expectativas provisórias, sedimentada na idéia de cura do infrator.

A força com que os seguidores de LOMBROSO professam a maior eficácia da responsabilidade social frente ao cotejo com o juízo moral contrasta, em grande medida, com a fragilidade do conteúdo propriamente dito de anormalidade. Trata-se de um campo movediço, onde tudo se permite e que seduz pela sua pretensa cientificidade aliada a uma linguagem tranquilizadora. Asseverava FERRI ${ }^{76}$ :

"Deve-se acrescentar que, também quando a sanção assume formas de medida de segurança ou de internamento com cura sanitária, o sentimento comum, pelo alarde social que todo o delito mais ou menos determina, não se opõe a que o delinqüente louco seja mandado para o manicômio judicial, o criminoso nato ou habitual para o sequestro, o

\footnotetext{
${ }^{75}$ Lyra \& Araújo. Op. cit, p.44. No mesmo sentido afirmou Mayrink (Op. cit, p. 217): "O grande pecado de Lombroso foi a sua generalização".

${ }^{76}$ Ferri. Op. cit, p. 238-239.
} 
delinqüente ocasional para a colônia agrícola, o menor para casas ou colônia de reeducação e o delinqüente passional seja mesmo perdoado".

Portanto, resta evidente que os positivistas não mensuraram bem as conseqüências de suas proposições, o exagero de seus argumentos, ou se assim atuaram, com consciência dos efeitos daquilo que era proposto, atuaram de forma semelhante ao tipo criminoso que pretendiam conter as mãos. Claro que houve pontos importantes a serem destacados e que se tornaram fundamentais para a evolução do saber criminológico, e o valor dado ao homem em suas investigações talvez tenha sido a mais acentuada herança da perspectiva positivista.

Todavia, se por um lado o homem (criminoso) passou a polarizar as atenções, de outro, esta polarização limitou à personalidade tudo o mais que poderia representar fator de criminalidade, eclipsando os olhos para tantas outras circunstâncias que, apesar de interagirem, não raro transcendem ao gênio humano. Vale, neste instante, utilizar a reflexão de LYRA $^{77}$ acerca do impulso que o pensamento de LOMBROSO aquilata, por vezes implicitamente, até os dias atuais.

"Quando autorizou a 5 $5^{\mathrm{a}}$ edição do Tratado Experimental do Homem Delinquente, Lombroso escreveu: 'Quanto mais ascendo no caminho, como aquele que, de mais alto, vê mais longe, eu diviso, cada vez melhor, as lacunas'. (...). Os que hoje são mais lombrosianos do que Lombroso devem meditar no seu exemplo".

Como se pode concluir, a doutrina positivista fez do cárcere um campo de teste para as hipóteses clínicas que recaíam sobre a figura do criminoso. Em se tratando de um local de

\footnotetext{
${ }^{77}$ Lyra \& Araújo. Op. cit, p.45.
} 
contenção de perigosos, o cárcere passou a ser encarnado como uma zona de risco, um depósito de ameaças.

Surgia a lógica do cárcere como um "mal necessário" ao bom convívio dos eleitos, na medida em que guardava sob ferros aqueles que foram expulsos da ceia pagã dos haveres materiais. Por certo que o discurso positivista e suas nuances guardam referência com o contexto histórico do qual foram tributários, mas não há como notar que perduraram para além deles, alcançando as práticas penitenciárias contemporâneas.

\subsubsection{Cenários teóricos contemporâneos do tratamento penitenciário}

O conceito de tratamento não abandonou suas origens, ou seja, continua associado a um conjunto de práticas políticas cujo objetivo principal está em conter e sequestrar indivíduos considerados, com base em critérios clínicos, anormais. O problema maior, então, está menos na sobrevivência do conceito do que na extensão equivocada que ele vem recebendo. E num contexto onde "o menos é mais", se faz urgente que a compreensão do mesmo seja revestida de segurança, clareza e previsibilidade para com as ações que busca orientar. Esta mesma preocupação foi expressa por AlvinO AUGUSTO DE $\mathrm{SÁ}^{78}$, quando afirmou que

“(...) tendo presente esta consciência de que todo sistema penitenciário, para ser, de fato, um sistema, deve ter suas bases conceituais bem definidas, coerentes e explícitas, bem como a consciência de que toda base conceitual tem seu viés ideológico e de que o que se deve evitar, a todo custo, são as contribuições ideológicas, tanto nas concepções, como na metodologia de trabalho".

\footnotetext{
${ }^{78}$ Sá, Alvino Augusto de. Manual de projetos de reintegração social. São Paulo: SAP/DRSP, s.d, p.13.
} 
A clareza nos objetivos de atuação, na escolha dos profissionais e nas políticas em geral que se pretendem aplicar no cenário do cárcere tem o condão de, ao menos, minimizar as pressões que, tanto externas quanto internas, possam transformar as práticas penitenciárias num "emaranhado de casuísmos"79. E ainda que se tenham algumas vozes efetivamente preocupadas em definir os limites conceituais capazes de melhor instrumentalizar o cotidiano do cárcere, há um volume ainda maior, sobretudo de gestores públicos e de setores mais incendiários da mídia, que negligenciam limites e se valem da própria inconsistência teórica para forjar ideologias repressivas e discriminatórias.

Nesta órbita, o tratamento não seria apenas um instrumento concreto de intervenção no homem encarcerado, mas representaria algo maior e mais abrangente, tal como uma ideologia voltada a aproximar, ainda que em linguagem mais sofisticada, o crime dos desvios de personalidade, partindo de uma leitura neolombrosiana do fenômeno criminal. Há diferenças entre a base positivista original e os contornos atualmente trabalhados pela criminologia clínica “ortodoxa” (estritamente médico-psicológica).

Se a doutrina tradicional de LOMBROSO inseria alguns indivíduos, previamente rotulados, em suas premissas antropológicas, nos dias atuais há uma pretensão de maior envergadura, pois é a própria teoria clínica, encabeçada pelas patologias psíquicas mais envolventes, que vai sair dos consultórios à procura dos "doentes".

Enquanto Lombroso observava para rotular, a estratégia moderna está em rotular para observar, ou seja, antes de tudo vale atribuir o desvio psíquico como razão do crime para, apenas na sequência, aferir o que já restou inexoravelmente etiquetado. Se, antes, LOMBROSO professava ter encontrado as "marcas de Caim", seus sinais físicos e psíquicos, hoje, por sua vez, Caim não somente é apontado como também é construído e forjado pelos estigmas que

${ }^{79}$ Ibidem, p.13. 
lhes são atribuídos. Trata-se de um trabalho mais audacioso no campo das estratégias de poder alicerçadas no saber.

RIOX, sociólogo canadense, tem dedicado seus estudos ao enfoque dado às disciplinas clínicas no contexto da compreensão do desvio. Assim, conforme expressa o autor, as questões de conteúdo mental têm se convertido em razões de marginalização e exclusão ${ }^{80}$. Esta “exasperação terapêutica" é denominada por BASAGLIA ${ }^{81}$ um instrumento de diferenciação, isto é, algo que se reveste de uma "ideologia da diferença", tida como aquela que se sustenta sobre a valorização de determinadas características individuais, cuja escolha se conduz pelo saber psiquiátrico.

A finalidade desta linha de pensamento (e também de ação) é, na essência, ampliar a fronteira entre a saúde e a enfermidade, entre a norma e o desvio, entre o indivíduo normal e o patológico ou inadaptado, a quem se insere uma etiqueta patologizante ${ }^{82}$.

"Com este mecanismo se tem chegado à psiquiatrização da vida social, com um elevado número de internações, um aumento de indivíduos submetidos a psicanálise e tratamento terapêutico, de modo que vivemos, como disse Kittrie, o 'Estado Terapêutico'; é dizer, as características que o Estado democrático atual tem adotado para controlar a população." 83

O tratamento passou, assim, a propiciar um verdadeiro ativismo terapêutico no campo penitenciário, eis que a busca por encontrar um corpo doente no criminoso acabou

\footnotetext{
${ }^{80}$ Apud, Bergalli, Roberto; Ramirez, Juan Bustos; Miralles, Teresa. El pensamiento criminológico. Vol I. Bogotá: Editorial Temis, 1983, p.86.

${ }^{81}$ Ibidem, p. 87.

${ }^{82}$ Ibidem, p. 87.

${ }^{83}$ Ibidem, p. 87-88.
} 
justificando uma série de restrições aos que já se encontram encarcerados, e um exemplo concreto deste argumento se dá no contexto da indispensabilidade do exame criminológico como requisito, quase que genérico, para a progressão de regime prisional no Brasil ${ }^{84}$.

Assim, antes de apresentarem singelo conteúdo técnico do campo médico, as definições psiquiátricas se prestam a circunscrever e proteger um espaço político, pelo que asseguram os valores normativos discutidos ou não aceitos pelos indivíduos. Neste cenário, é evidente que a própria definição de enfermidade esteja dependente do cenário político que busca escudar, e é a aparência de enfermidade, e não o seu conteúdo propriamente, que passa a determinar a

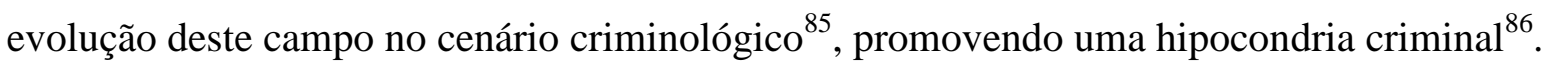

Ao lado das pretensões da clínica, destacadamente a de caráter psiquiátrico, de se consolidar como interlocutora necessária no debate criminal - o que de não deixa de se consumar numa busca legítima, desde que ponderada e sem os excessos de querer explicar quase que toda e qualquer conduta criminosa pela lente médica - há um espaço importante reservado ao tratamento penitenciário, como bem destacou $\mathrm{SÁ}^{87}$ :

\footnotetext{
${ }^{84}$ Sobre a discussão em torno do exame criminológico e suas matrizes ideológicas Cf. Sá, Alvino Augusto de. Criminologia clínica e psicologia criminal. $2^{a}$ ed. São Paulo: RT, 2010, p. 190-204.

${ }^{85}$ Bergali, et ali. Op. cit, p. 87.

${ }^{86}$ Questionando o próprio conteúdo da vaga expressão "enfermidade mental", novamente Basaglia (Ibidem, p. 87) adverte que "a verdadeira abstração acerca da enfermidade mental não está em sua existência, senão nos conceitos científicos que a definem sem que os confrontem com fatos reais". Ou seja, o que pretende o autor é apresentar um quadro em que as anomalias psíquicas são, não raramente, manejadas de forma em si mesmas esquizofrênicas, pois que não apresentam referência clínica com o real, e por isso se revestem de matrizes ideológicas, e muito além de meros instrumentos voltados a assegurar a saúde mental dos pacientes. E arremata dizendo que "com as definições se etiqueta e se acentua a diferença do individuo, de modo que o psicopático, o esquizofrênico, acabam por converter-se no 'diferente' (...)". No mesmo sentido, porém professando o uso indiscriminado da atribuição de psicopatia, ponderou T. Miralles (Miralles, Teresa. O controle formal: La cárcel. In: Bergalli, Roberto; Ramirez, Juan Bustos; et ali. El pensamiento criminológico. Vol II. Bogotá: Editorial Temis, 1983, p. 106): "Na prática penitenciária a classificação terapêutica mais utilizada é a de 'personalidade psicopática'. Recordemos a constelação de características que este conceito tem provocado na ciência médico-psiquiatra, de modo que qualquer conduta desviada do normalmente esperado pode ser encarada dentro de alguma definição do conceito de psicopatia".

${ }^{87}$ Sá. Op. cit, p.15.
} 
"Não há que se negar a prática de crimes que, justificadamente, chocam a opinião pública, os quais, por seu requinte de crueldade, ou que seja por seu caráter de estranheza, por certo estão associados a algum quadro mórbido e doentio da personalidade. No entanto, os autores de tais crimes não constituem, em absoluto, a maioria da população carcerária, não se justificando que, apesar dos mesmos se fazerem muito mais presentes na mídia e na opinião pública, se trace, a partir deles, toda uma política criminal, na linha de um modelo médicopsicológico, já de longe, ultrapassado”.

O autor mencionado não quis refutar a validade do tratamento nos dias de hoje, nem externou sua posição avessa à execução de suas premissas teóricas no cenário penitenciário atual. Como já ressalvado antes, o que se pretende, e esta foi uma preocupação expressa por SÁ, é evitar que o discurso sobre o qual se erige o tratamento possa, em virtude de sua sedução, traçar a rota de toda e qualquer investida que se faça no cárcere ${ }^{88}$. Ao contrário, é sempre salutar que se recordem, quantas vezes forem necessárias, que o tratamento há de ser uma via estreita e, tomando o reduzido público que deveria atender, subsidiária perante outras propostas menos traumáticas.

Assim, quadra repisar, o tratamento penitenciário não é uma via que deve ser suprimida, eis que indubitavelmente presta seu serviço ao preconizar técnicas de intervenção no homem que pratica um crime impelido por efetivo transtorno de ordem mental. Que esta circunstância existe, ninguém o nega; o que se nega é a supervalorização teórica e ideológica de uma perspectiva cuja práxis já denunciou ser reconhecidamente inferior ao peso que se professa.

\footnotetext{
${ }^{88}$ Assim, tendo por base uma concepção causalista do crime, este surgiria como um desdobramento necessário de um comportamento direcionado à transgressão. Como muito bem ressaltou Sá (Op. cit, p. 14), "uma primeira decorrência desse tipo de concepção é que a 'causa' nos possibilita, ainda que enganosamente, uma explicação do fenômeno, ou seja, do crime. Em função disso, a concepção causalista apresenta-se mais convincente e sedutora".
} 
Neste prisma, ZAFFARONI \& PIERANGELI ${ }^{89}$ consideram que a criminologia positiva pode ser denominada de tradicional, a quem atribui o papel de representante dos pressupostos políticos que se encontram na base do sistema penal, com quem aquiesce de forma explícita, sem constrangimentos, convertendo-se assim numa "ideologia de justificação" do próprio sistema e do controle por ele empreendido.

Como já afirmado, o tratamento como prática penitenciária moderna não nega a herança positivista e toda a sua carga ideológica, mas exerce um papel que merece destaque tanto para que se reconheça sua validade, ao menos enquanto existir o cárcere em suas mais variadas formas, quanto para que, reconhecendo sua existência, se possa domar o conceito (e consequentemente as práticas nele alicerçadas) dentro dos limites de um crime cometido enquanto ação orientada por transtornos mentais que, de forma concreta, atuaram decisivamente na realização da conduta criminosa.

O esboço de um conceito tradicional de criminologia clínica (criminologia aplicada ao contexto da execução penal) foi construído por $\mathrm{SA}^{90}$ :

"Criminologia clínica é a ciência que, valendo-se dos conceitos, conhecimentos, princípios e métodos de investigação e prevenção médicopsicológicos (e sócio-familiares), ocupa-se da pessoa do apenado, para nele investigar a dinâmica de sua conduta criminosa, sua personalidade e seu 'estado perigoso' (diagnóstico), as perspectivas de desdobramentos futuros da mesma (prognóstico) e assim propor e perseguir estratégias de intervenção, com vistas à superação, ou contenção de uma possível tendência criminal e a evitar uma recidiva (tratamento). Portanto, dentro desta concepção tradicional de criminologia clínica, são idéia centrais as de

${ }^{89}$ Zaffaroni \& Pierangeli. Op. cit, p. 159.

${ }^{90}$ Sá. Op. cit, p. 14. 
diagnóstico, prognóstico e tratamento. A conduta criminosa tende a ser compreendida como conduta anormal, desviada, como possível expressão de uma anomalia física ou psíquica, dentro de uma concepção prédeterminista do comportamento, pelo que ocupa lugar de destaque o prognóstico de periculosidade".

Em resumo, nossa posição não é de negar absolutamente a estratégia denominada de tratamento penitenciário, mas sim de restringi-la ao máximo, a fim de que venha a ser utilizada exclusivamente em casos especiais, quando a conduta do agente estiver verdadeiramente com algum transtorno psíquico e, portanto, merecer de tratamento clínico, curativo e em sede de medida de segurança ${ }^{91}$.

\subsection{RESSOCIALIZAÇão}

Os ideais criminológicos do positivismo, dentre eles o tratamento e seus desdobramentos, passaram a angariar maiores espaços nas pautas de ação oficial à medida que eram recepcionados pelo discurso jurídico - e isso se deu com decisiva contribuição da Escola de Marburgo ou Jovem Escola Alemã de Política-Criminal ${ }^{92}$, cujo maior expoente foi o jurista alemão FRANZ VON LisZT. O professor de Berlim foi um árduo defensor da política-criminal (kriminalpolitischen) enquanto instrumento de defesa dos interesses sociais, e isso fez com

\footnotetext{
${ }^{91}$ Não é o espaço para adentrar nas importantes discussões em torno da medida de segurança, dentre elas aspectos referentes a preferência pelo tratamento ambulatorial frente a internação, bem como à medida de desinternação progressiva. De fato, assim como em relação às penas privativas de liberdade em geral, a medidad de segurança se reveste (independentemente da natureza jurídica que lhe é conferida) de grave ato de segregação que muito pouco resolve os problemas evidenciados com a prática do ilícito penal. Para uma melhor contextualização acerca da matéria Cf. Ribeiro, Bruno de Morais. Medidas de segurança. Porto Alegre: Sergio Antonio Fabris, 1998.

${ }^{92}$ Referência feita por Gárcia-Pablos \& Gomes (Op. cit, p. 195). Lembram ainda os autores a importância de Liszt contida no famoso "Programa de Marburgo", de 1872, cujo teor representou um impulso fundamental aos futuros estudos no campo da poítica-criminal, sobretudo pelo fato de propor "um saudável equilíbrio entre os sistemas clássicos e liberais e a necessária abertura do método positivista." Impõe registrar que a data fornecida por Gárcia-Pablos \& Gomes não é pacífica, havendo ampla literatura que atribui o ano de 1882 como o de publicação do Programa de Marburgo. Neste sentido Cf. Rivera Beiras. Op. cit, p. 13; Bitencourt. Cezar Roberto. As funções da pena no Estado Democrático de Direito. In: Bitencourt, C.R. Tratado de direito penal. 13 ${ }^{\mathrm{a}}$ ed. v.1. São Paulo: Saraiva, 2008, p.60.
} 
que a "disciplina" ganhasse considerável relevo, tendo influenciado inúmeras legislações penais, dentre elas a brasileira ${ }^{93}$.

Como destaca ANTONio GÁRCiA-PABlos DE MolinA ${ }^{94}$, em seus primeiros escritos Von LiSZT não costumava utilizar o termo ressocialização (Resozialisierung), preferindo a idéia de melhora (Besserung) para traduzir a finalidade da punição enquanto cura do delinquente. Até a $23^{\mathrm{a}}$ edição de sua obra magna (Lehrbuch), organizada por Schmidt após a morte de seu autor, não se vislumbrava a palavra ressocialização, que somente veio a ser utilizada na $25^{\mathrm{a}}$ edição do Lehrbuch de LISZT, em 1927, juntamente com os termos educação (Erziehung) e

${ }^{93}$ Zaffaroni \& Pierangeli (op. cit, p. 302-305) apontam a influência que o Código Penal de 1940 teria recebido de Liszt e sesu apoiadores. Ademais, asseveram os autores que Von Lizst foi tributário da herança filosófica alemã, que oscilava entre o materialismo e o espiritualismo, e que em razão desta dicotomia recepcionou os postulados do positivismo italiano com algumas particularidades. Ao mesmo tempo em que o alemão negava autodeterminação ao criminoso, fundava a sua proposta de responsabilidade penal sobre uma possibilidade de "normal motivação" por parte do delinquente. Isto demonstrava que Liszt estava a meio caminho do transcendentalismo e da pragmática, expressando o embate de seu tempo. Apesar das contradições que o pensamento de Liszt professava, foi ele pioneiro ao propor uma teoria da pena como fim (ponto reproduzido e estudado até os dias atuais), direcionando maior atenção à finalidade preventiva especial com escopo na atuação terapêutica sobre o criminoso. Figueiredo Dias \& Costa Andrade (Criminologia. O homem delinqüente e a sociedade criminógena. $2^{\mathrm{a}}$ reimpressão. Coimbra: Coimbra Editora, 1997, p. 206) ainda destacam que uma das teses centrais de Liszt dizia que "(...) o criminoso e não o crime que se deve punir. O crime, em si, não é uma doença, mas apenas um sintoma de uma doença que radica em equilíbrios patológicos das diferentes tensões intra-psiquicas. A grande tarefa da política criminal é, pois, atuar sobre este criminoso latente que persiste para além das singulares manifestações de delinqüência ou, mesmo, sem elas." Liszt ainda teria escrito seu nome na história do direito penal ao fundar em 1889, junto com Van Hamel e Adolphe Prins, a União Internacional de Direito Penal (Internationale Kriminalistische Vereinigung - IKV). A trajetória da Instituição foi interrompida em razão da deflagração da I Guerra Mundial, mas foi posteriormente reorganizada em 1924 com o surgimento da Associação Internacional de Direito Penal (Association Internationale de Droit penal). Para um estudo acerca da AIDP Cf: <www.penal.org.br> e <www.aidpbrasil.org.br>, sítios virtuais da matriz internacional e do grupo brasileiro, respectivamente.

${ }^{94}$ Molina, Antonio Gárcia-Pablos. La supuesta función resocilizadora del derecho penal: utopia, mito y eufemismo. Anuário de Derecho Penal y Ciencias Penales. n.2. v. 32, 1979, p. 649. O autor ainda destaca que num primeiro instante o termo ressocialização carecia do caráter de finalidade ou meta que hoje lhes são associadas, pelo que integrava um jogo de palavras que se prestavam muito mais a legitimar a intervenção estatal na pessoa do delinquente, sob a rubrica de melhoramento, educação e propriamente ressocialização. E pouco a pouco, esta última expressão foi ganhando espaço e se consolidando como o expoente da proposta moderna de intervenção no campo da execução penal. A consagração definitiva da expressão não se encontra, portanto, vinculada apenas ao horizonte normativo dos fins da pena, senão que está igualmente fundada no contexto prático da execução das penas e medidas de segurança privativas de liberdade. A isto se soma a importante contribuição do jurista alemão Schüller-Springorum que, no final da década de 60, abriu espaço para a tese de que a punição não haveria de infringir um mal desnecessário, já que ela era um mal em si suficiente para a reprovação do ato e do seu comitente, deixando a execução penal de responder aos reclamos da defesa social ou da mera restauração da ordem jurídica, para se debruçar sobre o projeto de ressocialização e reforma do delinquente (Idem. Ibidem). 
melhora (Besserung). Pode-se intuir, então, que esta tenha sido a primeira aparição do termo ressocialização em um trabalho científico.

Se o substrato da idéia de ressocialização representava um legado do pensamento positivista e, portanto, restaria sempre viva a referência genética ao prócer C. LOMBRoso, era interessante observar que as construções em torno do ideal ressocializador tentaram abrigar aspectos que ora reeditavam com fidelidade as premissas positivistas, ora buscavam afastar-se delas.

E por meio deste confronto entre a herança e a tentativa de adaptação às renovadas correntes criminológicas, especialmente as de caráter sociológico, nasceu um conceito originariamente eclético e polêmico, capaz, dada a sua dimensão, de perdurar até os dias atuais em razão de sua imprecisão ${ }^{95}$. Trata-se, portanto, de um conceito capaz de se reinventar dada a dificuldade de se definirem as fronteiras de seu conteúdo.

A falta de unidade em torno do tema é tamanha que nem mesmo a nomenclatura adotada é pacífica. Surgem nomes dos mais diversos para retratar um conteúdo de contornos mais ou menos idênticos, e neste particular estava certa RoSANGELA SANTA RITA ${ }^{96}$ quando disse que tal diversidade tem contribuído para que o próprio conceito de ressocialização reste tão vulgarizado a ponto de seu uso se aproximar do senso comum. Inúmeros autores reconhecem que o uso indiscriminado das mais variadas terminologias para se referir a uma mesma idéia acaba por desacreditá-la ainda mais ${ }^{97}$.

\footnotetext{
${ }^{95}$ Idem, p. 650.

${ }^{96}$ Rita, Rosangela Peixoto Santa. Mães e crianças atrás das grades: em questão o princípio da dignidade da pessoa humana. Brasília: Ministério da Justiça, 2007, p. 36 (nota de rodapé n.6). A autora, inclusive, prefe utilizar a expressão "reabilitação" em lugar de ressocialização.

${ }^{97}$ Neste sentido é a crítica do criminólogo uruguaio Raúl Cervini (Os processos de descriminalização. Trad. da $2^{\mathrm{a}}$ ed. espanhola Luiz Flávio Gomes. São Paulo: RT, 1995, p. 46) "Os termos 'reeducação', 'reabilitação', 'regeneração', 'instrução' e outros comumente utilizados têm escasso significado pois, uns e outros, tentam atribuir à função penal, em seu aspecto penitenciário, uma finalidade que não lhe é própria, conquanto se lhe exige algo que não pode realizar".
} 
Neste sentido, e sem ter a pretensão de esgotar todos os possíveis signos utilizados como referência ao ideal ressocializador, importa registrar os mais comuns: reforma, reeducação, reabilitação, laborterapia, correção, emenda, reinserção social, reintegração social - e isso apenas para mencionar o clássico catálogo das chamadas ideologias "re". Foi neste horizonte que R. CERVINI ${ }^{98}$ consignou que “com as expressões 'reeducação', 'reinserção social' ou 'ressocialização', atribui-se à execução das penas e medidas penais privativas de liberdade uma mesma função primordial: a de corrigir e educar o delinquente".

Apesar de tantos fatores predisponentes ao fracasso, o que se observa é que tanto a terminologia (nas suas facetas variadas) quanto o próprio conceito de ressocialização continuam vigentes, possivelmente sem a opulência de outrora, mas indubitavelmente ainda tidos como importante pauta política dos órgãos estatais, mesmo quando tal importância não passa de artifício retórico. Nas palavras de GÁRCIA-PABLOS DE MOLINA ${ }^{99}$

\footnotetext{
${ }^{98}$ Cervini. Op. cit, p. 32. Bruno Ribeiro (As modificações recentes havidas no conceito de ressocilização ou reintegração social e a discussão atual acerca desse conceito. In: Prado, Luiz Régis. Direito penal contemporâneo: estudos em homenagem ao Professor José Cerezo Mir. São Paulo: Rt, 2007, p.110.) afirmou que "a idéia de ressocialização pode assumir uma grande variedade de significações, que de um modo geral situamse entre um máximo e um mínimo de conteúdo moral."

${ }^{99}$ Molina, Antonio Gárcia-Pablos. La supuesta función resocilizadora..., p. 648. Gárcia-Pablos apresenta um alcance tridimensional ao termo ressocialização (p. 652), e destaca a importância em se definir os possíveis horizontes de aplicação importa para aclarar a sua aplicação concreta, pois é exatamente a ambigüidade e equivocidade da expressão o que tem permitido a sua imposição. Em primeiro lugar, o ideal ressocializador estaria vinculado à idéia de antiretribucionismo dogmático, no qual uma sociedade prescindiria da simples coação para conquistar a adptação de seus membros, e nesta proposta estaria travestida grande parcela do "ímpeto pedagógico" (p. 653) que o Estado conferiria à pena. Noutro aspecto, a ressocialização remeteria a uma concepção assistencial promovida pelo direito penal, que deixaria de se autocentrar no fato para abrigar, com mais vigor, a análise do agente do fato. Assim, o delito haveria de ser tratado como um "acidente social" (p. 653), e as penas e medidas de segurança exerceriam um papel de remédios assistenciais com propósito curativo. Por fim, uma terceira via de interpretação do termo ressocialização, conforme Gárcia-Pablos, o aproximaria da idéia de neorretributivismo enquanto "política criminal que persegue uma eficaz e racional luta contra a criminalidade e, em definitivo, a coativa adaptação do cidadão ao 'status quo' mediante um direito penal efetivo". (p. 654). Trata-se, em última instância, de uma fundamentação baseada na adaptação coativa através da ressocilização ou, em outras palavras, de uma ressocialização em sua máxima versão utilitária e racional, a meio caminho da contenção e da reeducação - ambas coexistindo em relação direta de proporcionalidade.
} 
“É certo que o termo 'ressocilização', talvez porque se associa à idéia 'antiretributivista', está na moda. Isto é, também, que todos usamos o mesmo sem a devida precisão: às vezes sem saber exatamente o que se quer afirmar e o que, de fato, se afirma. A própria imprecisão do conceito e sua elasticidade tem influenciado, também, em sua pronta e acrítica recepção no mundo jurídico, sem as devidas verificações prévias em relação a seu conteúdo".

Ao lado das já conhecidas expressões relatadas acima, não é igualmente difícil encontrar outras, que apesar de um pouco mais elaboradas e sugestivas, inclusive, não deixam de fornecer o mesmo "recado" sob rubricas diferentes, ampliando assim as dificuldades de compreensão acerca da matéria e legitimando, quase que para tudo, a sua aplicação. Termos como "terapêutica do comportamento"100, "encarceramento terapêutico"101, "meca da prevenção especial"102 " "tratamento social" 103 e tratamento ressocializador ${ }^{104}$ servem, quando

\footnotetext{
${ }^{100}$ Dias, José de Figueiredo; Andrade, Manuel da Costa. Criminologia. O homem delinqüente e a sociedade criminógena. $2^{\mathrm{a}}$ reimpressão. Coimbra: Coimbra Editora, 1997, p. 216.

${ }_{101}$ Laplante, Jacques. Crime et traitement. Introduction critique à la criminologie. Montréal: Boréal Express, 1985, p.127.

${ }^{102}$ Molina, Antonio Gárcia-Pablos. La supuesta función resocilizadora..., p. 651

${ }^{103}$ Bray, L. de. Servicio social e delincuencia. Madrid: Aguilar, 1973, p. 111. Ao abordar o tema do "tratamento social", que pode ser entendido como "conjunto de medidas (médicas, psicológicas, educativas, de serviço social) que se tomam em relação com o delinquente para facilitar sua reinserção social e assim evitar que reincida.” (p.125), L. de Bray, que foi Assistente Social e Inspetora Prisional na Bélgica, destaca com especial ênfase o papel do assistente social em suas relações com o recluso. Assim, Bray assevera que o ingresso de um delinquente no cárcere livra a sociedade, ainda que provisoriamente, da ameaça representada por sua conduta criminosa. Neste cenário, a punição realizada através do encarceramento exerceria o importante papel de tratar o criminoso a fim de que ele, ao retornar ao convívio social, seja capaz de levar "uma vida conforme as leis e normas sociais, e ao que se deseja" (p.111).

${ }^{104}$ Este é, segundo a proposta teórica (des)construção ora lançada, a utilização terminológica mais controvertida e problemática, pois deixa à nu a confusão entre os conceitos de tratamento penitenciário e ressocialização. $\mathrm{O}$ fato delas apresentarem pontos em comum, sobretudo no que toca a pretensão de reforma do encarcerado, não faz com que se concretizem em projetos político-criminais idênticos. Pelo contrário, as duas subsistem numa relação de complementariedade, e não de suplementação, tal como poderia ser apreendida numa leitura superficial. O "tratamento ressocializador" não se submete as mesmas bases teóricas e aos similares métodos de aplicação do tratamento penitenciário (Cf. Item 1.1) e, portanto, eles representam horizontes independentes, orientados por razões políticas, sociais e econômicas próprias. Assim, este deve ser um termo proscrito da literatura, eis que em nada agrega na compreensão da disciplina e, quando muito, acarreta confusões e promove reduções inadequadas no sentido de cada um dos horizontes, na medida em que funde um a outro. Considerando que, ainda hoje, muitos setores do campo penitenciário ainda se utilizam desta equivocada terminologia, que não raro se presta a disfarçar a intervenção clínica mais tradicional no campo penitenciário, tal recolocação clara de
} 
muito, para emprestar mais curiosidade do que conhecimentos técnicos acerca do conteúdo ressocializador.

Logo, a tarefa de identificar as artimanhas que envolvem o conceito de ressocialização há de ser prévia, antes mesmo da apresentação de sua experiência histórica e dos desdobramentos atuais que o tema vem sofrendo. Há, como se pode observar, uma fluidez teórica, um clima de permissibilidade que vai alavancando um conjunto de práticas penitenciárias sob o embuste de uma humanizada e salvadora intervenção penal. Ao saber que o terreno é intencionalmente arenoso, o mínimo a fazer é assumir uma postura mais cautelosa e ao mesmo tempo crítica acerca dele.

\subsubsection{O cenário de emergência do ideal ressocializador}

A análise histórica que se seguirá não possui a pretensão de exaurir as memórias da punição, sequer aquelas que retratam propriamente o uso do cárcere enquanto engrenagem última no aparelho de controle social. Na linha seguida por DAVID GARLAND ${ }^{105}$, o que se pretende é realizar uma "história do presente", imbuída muito mais de uma preocupação crítica de entender o cenário penitenciário atual (e de propor alternativas a ele) do que de uma pretensão

cada uma das propostas haverá de orientar, igualmente de forma mais explícita, os argumentos que sustentam as práticas no cárcere.

${ }^{105}$ Garland, David. A cultura do controle. Crime e ordem social na sociedade contemporânea. Trad. André Nascimento. Rio de Janeiro: Revan, 2008, p. 42. Este trabalho de Garland tem por escopo compreender como as respostas ao crime assumiram a forma contemporânea, ou seja, quais processos foram decisivos para a sua formatação. Assim como fizeram Rusche \& Kirchheimer (Cf. Punição e estrutura social. Trad. Gizlene Neder. 2 ed. Rio de Janeiro: Revan, 2004). no primeiro quarto do século XX, Garland assevera a imbricação entre a punição e a constituição dinâmica da sociedade. O controle exercido através do aparelho penal seria, então, um reflexo das expectativas sociais ou, melhor dizendo, seriam as próprias expectativas sociais institucionalizadas ou "oficializadas". Ao aproximar os autores mencionados, não se está admitindo que tenham eles construído teorias similares, mas apenas que no campo da teoria social, ambos acabaram tangenciando os pontos sensíveis de interesse desta pesquisa. Enquanto D. Garland analisou as implicações da formatação social na estruturação do seu aparato de controle, avaliando por isso inúmeras fontes e fatores, Rusche \& Kirchheimer, herdeiros de uma teoria crítica de viés marxista, consignavam a obviedade de que formas específicas de punição correspondam a um determinado estágio de desenvolvimento econômico. 
histórica de compreender o passado. Assim, “o objetivo não é pensar historicamente o passado, mas sim, através da história, repensar o presente". ${ }^{106}$

As investigações que se apresentam acerca do cárcere e, em particular, aquelas abordagens criminológicas das formas de concepção do crime e do criminoso, não raro demonstram uma desesperança e um "cansaço" no sentido de avançar para além da exploração do campo. Acostumaram, assim, a ver as coisas como são e com isso foram paulatinamente perdendo a noção histórica capaz de ampliar as razões não do fracasso apenas, mas das mudanças possíveis.

A sociedade industrial dos séculos XVIII e XIX, atuando com base na livre demanda e se alimentando através da exploração do trabalho assalariado, se valeu do aparato penal para assegurar a proteção de bens jurídicos individuais com base num conhecimento criminológico preocupado com a etiologia do comportamento criminoso e que escolhia os cidadãos excluídos do mercado de trabalho e de consumo como os clientes a serem catequizados para a lógica mercantil então em franca expansão. E esta engenharia social, da qual o cárcere constituía uma importante engrenagem, permaneceu ao menos até o término da segunda grande guerra mundial. Como pontuou R. BERGALLI ${ }^{107}$,

"quem não aprendia as regras de comportamento social no mundo fabril, deveria então aprende-las no âmbito penitenciário. (...) o qual se articulou sobre um tratamento penitenciário prioritariamente orientado para o retorno a uma vida social em que o trabalho dependente foi uma constante. Assim estava constituído o horizonte de atividade de um vasto número de sistemas penais no ocidente".

\footnotetext{
${ }^{106}$ Idem, p. 43.

${ }^{107}$ Bergalli, Roberto. Crítica a La criminologia. Hacia uma teoria crítica Del control social em América Latina. Bogotá: Editorial Temis, 1982, p.10.
} 
É possível precisar que o ideal ressocializador começou a interessar à agenda políticocriminal dos países centro-ocidentais (Europa ocidental e EUA) a partir da segunda metade do século XIX, em decorrência das discussões que já palpitavam o cenário criminológico em decorrência das discussões lançadas por Lombroso, ainda que a consolidação de suas premissas seja de época posterior.

Na transição para o século XX, e em meio a um aumento no padrão de vida das classes menos privilegiadas, decorrência de um período de razoável estabilidade política e prosperidade econômica, nascia o embrião daquilo que D. GARLAND, mais tarde, viria a chamar de previdenciarismo penal $^{108}$. O economista francês WORMS ${ }^{109}$ traduziu o ideal que deveria orientar a punição penal da época quando concluiu que reduzir os dias de um cidadão produtivo, ou ampliar seu encarceramento de forma irracional e sem uma justificativa plausível, num momento em que os indivíduos são concebidos como bons produtores/consumidores, ao menos no plano moral, configuraria um grande desperdício para a sociedade. Assim, antes de ser útil, a prisão representaria um fator de retrocesso social.

Vale ponderar que o pensamento de WORMS não estava preocupado em analisar a violência que o sistema penal promoveria aos cidadãos, sobretudo os do "baixo clero", mas centrava sua consideração na transferência destes mesmos cidadãos da engrenagem do mercado para outras engrenagens alheias à produção (ao menos diretamente). O exemplo deixa claro o papel que a estrutura social desempenha na construção do cenário punitivo ${ }^{110}$.

\footnotetext{
${ }^{108} \mathrm{O}$ sociólogo escocês radicado nos EUA aponta sob esta rubrica os valores e práticas institucionais caracterizadoras da área entre os anos de 1890 e 1970 - Cf. Garland. Op. cit, p. 44.

${ }^{109}$ Apud, Rusche \& Kirchheimer. Op. cit, p. 195

${ }^{110}$ Como já disse D. Garland (Op. cit, p. 47), retratando a face formal do controle do crime, "as instituições formais de controle do crime tendem a ser reativas e adaptáveis. Elas operam buscando complementar os controles sociais da vida comum, apesar de muitas vezes interferirem nesses controles sociais, prejudicando sua efetividade."
} 
Ademais, várias questões convergiram, desde o fim do século XIX, para o fracasso da prisão como castigo, o que acabou criando a correspondente necessidade de uma mudança na política criminal. O cárcere, até então lastreado em justificativas essencialmente retributivas, perdeu o apoio político, social e, inclusive, ideológico de outrora. Com isso, o Estado teve de rever seus modelos de controle social, dentre eles o punitivo, a fim de amoldá-lo ao momento capitalista-imperialista no qual se via imerso ${ }^{111}$. A necessidade de adaptar-se às críticas que o modelo baseado no castigo poderia gerar, bem como as demandas advindas do próprio modelo sócio-econômico exigiam uma reação ao crime que, nas palavras de ROSA DEL $\mathrm{OMO}^{112}$, haveria de "racionalizar as desigualdades por ele produzidas".

Neste horizonte, as contribuições teóricas do pensamento positivista, sobretudo com seu conceito científico de periculosidade social, tornaram possível a mudança na orientação ideológica da punição, notadamente quando pugnaram a ampliação do papel do indivíduo na dinâmica criminal, deixando de lado, propositalmente, o protagonismo do ato defendido pelos antecessores clássicos. De posse desta preocupação central, os positivistas passaram a tencionar seus pressupostos para o esquadro da política criminal, interessados em assegurar concretude aos dados empíricos que vivificavam as mais variadas teses acerca da etiologia do crime. E vislumbraram no cárcere o mecanismo ideal para isso.

Nesta esteira, as prisões se tornaram verdadeiros laboratórios voltados à transformação dos indivíduos, pois mediante o tratamento ressocilizador estaria lançada a crença de que a pena se prestaria a "ajudar o indivíduo a voltar a ser livre"113, e faria isso mediante a internalização

\footnotetext{
${ }^{111}$ Miralles, Teresa. Op.cit. p. 103-104.

${ }_{112}$ Apud, Miralles. Op. cit, p. 103-104.

113 Miralles. Op. cit, p.104. A influência da Escola Positiva pôde ser sentida, também, pela utilização dos critérios de classificação dos estabelecimentos penais que, com algumas adaptações, guardam ainda nas legislações vigentes características muito próximas àquelas preconizadas por Enrico Ferri (Op. cit, p. 347): "Os estabelecimentos serão assim organizados: para mulheres delinquentes (comuns e enfermas mentais) - para delinquentes menores (escolas profissionais e de correção, navios-escola, casa de trabalho, colônias agrícolas, estabelecimentos de vigilância) - para delinquentes loucos (manicômio criminal) - para delinquentes natos, mais ou menos incorrigíveis (teratocômio, especial colônia de trabalho com sequestro rigoroso) - para delinquentes
} 
das normas regulares de conduta acostadas nas leis penais. E como ressaltaram FIGUEIREDO DIAS \& COSTA ANDRADE ${ }^{114}$, abordando a influencia do positivismo na construção da ideologia do tratamento ressocializador,

\begin{abstract}
"se não sobreviveram as teorias especificamente positivistas - as teses antropológico-causais - a verdade é que muito ficou e muito perdura ainda da sua herança: não tanto no que toca aos parâmetros metodológicos, quanto no que respeita as linhas de força da sua ideologia político-criminal. Estamos a pensar sobretudo na chamada ideologia do tratamento, que de modo algum se pode considerar definitivamente superada e cujos perigos estão longe de se poderem considerar neutralizados".
\end{abstract}

A gestação dos sistemas penais da modernidade trouxe consigo um ideal secularizador, lastreado na igualdade entre os homens, inclusive estendida aos que eram submetidos ao controle punitivo. As razões de fundo, portanto, estavam em eliminar a vingança privada como forma de sanção, bem como no interesse em estabelecer limites claros a intervenção punitiva do Estado.

Contudo, tais premissas foram pisoteadas pelo direito penal dos Estados totalitários ${ }^{115}$, e somente foram reestabelecidas com o auxílio do constitucionalismo social nascido com o fim da Segunda Guerra mundial, momento em que as bases do direito penal e da política criminal

habituais e reincidentes (sequestro rigoroso, casa de trabalho, colônia agrícola) - para delinquentes ocasionais (colônia agrícola, casa de trabalho, detenção simples ou rigorosa)."

${ }^{114}$ Figueiredo Dias \& Costa Andrade. Op. cit, p. 18.

115 Também o totalitarismo soviético produziu o seu modelo de ressocialização. Não há como negar que o conteúdo do paradigma ressocilizador encontrou na criminologia de viés socialista uma grande acoberta. Tanto assim que Stiller (Apud, Gárcia-Pablos. Op. cit, p. 646) pontuava que a proposta da ressocilização não haveria de se limitar a uma mudança externa do sujeito, mas que suas estratégias deveriam pretender uma alteração na face interna do comportamento individual, ou seja, na atitude psicológica do sujeito a fim de estruturá-la de acordo com a moral socialista. 
foram orientadas para concretizar a retribuição por meio da pena e, além dela, alcançar o objetivo reabilitador.

É importante registrar que a década de $30 \mathrm{fez}$ emergir no mundo ocidental um modelo de gestão estatal conhecida como Welfare State (Estado de bem-estar social). Tal modelo não gerou efeitos semelhantes em todas as regiões onde foi aplicado. Nos Estados Unidos, por exemplo, o sistema de bem-estar foi menos alardeado do que na Europa, pois a providência pública era necessária em escala bem inferior do que aquela registrada na Europa devastada pela contingência da Primeira Guerra Mundial. A força com que o regime capitalista se reestruturava em solo norte-americano fez aquela nação experimentar um rápido crescimento após a crise de 1929, e junto da acumulação vertiginosa de capitais veio a necessidade de explicar o incremento na criminalidade que este fenômeno acarretava.

Esta circunstância favoreceu o desenvolvimento dos estudos sociológicos causal-explicativos aptos a oferecer uma visão global do fenômeno da criminalidade. A Europa, no mesmo período, se viu envolvida por uma crise econômica e institucional muito superior. Em razão da catástrofe decorrente do conflito bélico, surgiram regimes totalitários que, pela própria natureza, não tinham nenhum interesse na compreensão da realidade que tanto lhes era favorável enquanto argumento de dominação do poder político. Desta feita, grande parte dos países europeus observou uma categórica negação à sociologia ${ }^{116}$.

A recomposição dos mercados de trabalho após o término do conflito bélico mundial, ocorrido na década de 40, contribuiu decisivamente para a consolidação de uma legislação laboral mais progressiva, decorrente da finalidade de bem-estar imposta pelas políticas dos Estados ocidentais. Este quadro vivenciado no amplo cenário social, de conquista de uma maior qualidade de vida para o maior número de cidadãos, possibilitou que os sistemas penais

${ }^{116}$ Cervini. Op. cit, p. 29-31. Isso de certa maneira ajuda a entender o motivo pela qual a tese da ressocialização permaneceu por muito mais tempo "na moda" na Europa do que nos Estados Unidos, até ser frontalmente atacada pelas constatações sociológicas que abalaram-lhe as finalidades prometidas. 
se convertessem em porta de ingresso para que os marginalizados conquistassem, por via reflexa, a condição necessária para gozar dos frutos de uma sociedade benfazeja, mas este ganho demandaria uma adaptação forjada aos ideais e valores socialmente estabelecidos ${ }^{117}$.

O modelo de Estado Providente ou de Bem-Estar Social (Welfare State), nascido após o término da Segunda Guerra Mundial, tinha como escopo o dever do Estado de planejar e dirigir de forma presente o funcionamento da sociedade, passando a assumir os espaços deliberadamente abandonados pelos modelos liberais de outrora. Havia, neste cenário, um peculiar interesse em manter níveis razoáveis de existência para as pessoas, com a justificativa de atenuar a vulnerabilidade que o período histórico tratou de fabricar ${ }^{118}$.

Se o discurso público denotava, num primeiro contato, um viés puramente humanitário o mesmo não poderia dizer após uma análise mais ampla das razões que de fato propiciaram a emergência do Estado Providência. Em meio aos transtornos sociais gerados pela guerra, em especial no contexto mercantil, se fazia necessário animar o espírito do capitalismo, tratando de lubrificá-lo por meio do estímulo ao movimento das relações econômicas, cuja base está fundada nas mais singelas relações de consumo.

Assim, a aproximação das instituições burocráticas do Estado para com a realidade social pulsante não tinha propriamente o caráter de apaziguar a dor da vulnerabilidade psíquica e material decorrentes das hostilidades da guerra, mas, antes disso, o móvel para tais medidas nasceu entre razões de índole econômica (a crise de 1929, por exemplo) e se manteve para satisfazê-las.

\footnotetext{
${ }^{117}$ Bergalli. Op. cit, p. 6-7. O criminólogo espanhol ainda complementa de forma muito pertinente a idéia aqui exposta, dizendo que: "Este aspecto é o que demonstra com mais evidência até qual ponto a ideologia ressocilizadora estava ligada a um modelo de sociedade de bem-estar, embora, ao mesmo tempo, também estivesse vinculada a uma orientação correcionalista."

${ }^{118}$ Cervini. Op. cit, p. 31.
} 
A incorporação de grande parcela da população ao consumo e à produção, mediante a criação de um grande sistema de seguridade social, não se faria gratuitamente, e seu preço estava na exigência de que os agraciados por este "grande irmão"119 se adaptassem a determinadas pautas de comportamento necessárias à manutenção do fluxo de capitais. Produção, consumo, criação de mercados, mais produção e, consequentemente, mais consumo. Esta era a lógica de fundo do Welfare State.

Se o bem-estar se ligava ao consumo, em relação direta, se pode intuir que o consumo deixava as pautas meramente econômicas para assumir um papel axiológico na sociedade, na medida em que as conduta adaptadas seriam definidas em razão da maior ou menor expressão da produção e do consumo. E, nesse sentido, muito bem se expressou CERVINI ${ }^{120}$ quando mencionou que:

"Trata-se, então, de disciplinar o sujeito no mercado, não somente como produtor ou trabalhador, mas também e, principalmente, como consumidor. Isto faz com que o controle social se dirija a quem não responde às pautas marcadas de consumo e produção, ou seja, aos chamados 'dissidentes ocidentais', dentre os quais, as seitas autosuficientes, os grupos hippies, as comunidades de volta à natureza, algumas comunidades imigrantes como os turcos na Alemanha, os drogados que concentram o consumo numa única mercadoria, etc; em suma, o controle social atingirá um tipo especial de marginal: aquele que embora seja membro da sociedade de um país, não consegue penetrar na intimidade de suas estruturas devido ao fato de não compartilhar as pautas de consumo e produção inerentes ao Estado de Bem-Estar".

\footnotetext{
${ }^{119}$ Para uma análise acerca de um modelo totalizante de Estado (que pretende ser onipresente), ainda que não totalitário. Cf. Orwell, George. 1984. Trad. Luiz Carlos Carneiro de Paulo. Rio de Janeiro: Bibliex, 2007.

${ }^{120}$ Cervini. Op. cit, p. 31.
} 
Assim, o fim da Segunda Guerra Mundial e o rápido desenvolvimento do capitalismo propiciaram e também se beneficiaram dos efeitos do processo de soerguimento do mundo, sobretudo dos Estados devastados pelo conflito armado. Nascia um "pacto entre capital e trabalho" "121 cujo imperativo estava, até certo grau, vinculado à idéia de bem-estar e pelo que propunha uma gradativa melhoria qualitativa da mão-de-obra enquanto uma mercadoria de troca.

A década de 50 marcou definitivamente o auge do ideal ressocializador, que no seu início poderia ser resumido como uma estratégia de intervenção terapêutica de corte essencialmente psiquiátrico e psicanalítico. E como destaca T. MIRALLES ${ }^{122}$, “a ressocialização é apresentada como a salvação do mundo carcerário, como a panacéia de todos os problemas e deficiências. Inclusive e especialmente os prisioneiros acreditavam nisso, e os psiquiatras também”.

O cenário social foi gracioso para os aportes ressocializadores da punição até meados da década de 70. Conforme diz D. GARLAND"123, "ainda nos anos 1970, quem lidava com o negócio do controle do crime compartilhava um conjunto comum de crenças sobre as molduras da justiça criminal e da prática penal."

A suficiente estabilidade social observada desde o período pós-guerra e a filosofia do modelo providente de Estado favoreciam que a sociedade concebesse a pena como uma oportunidade

\footnotetext{
${ }^{121}$ Prado, Carolina. Trabajo, exclusión y cárcel (en el empuje neoliberal hacia las fronteras del proyeto de las sociedades democráticas). In: Bergalli, Roberto; Beiras, Iñaki Rivera; et al. Violencia y sistema penal. Buenos Aires: Del Puerto, 2008

${ }^{122}$ Miralles. Op. cit, p. 105. No mesmo sentido foi a manifestação de Bruno Ribeiro (As modificações...p. 110): "Até meados dos anos 60 ou início dos anos 70, aproximadamente, quando ainda se acreditava na eficácia curativa da execução penal, desde que ela possuísse uma orientação terapêutica e pudesse influenciar os reclusos durante um período de tempo suficiente, prevaleceram concepções de tratamento ressocializador vigorosamente influenciadas pelo positivismo criminológico."

${ }^{123}$ Garland. Op. cit, p. 45.
} 
de promover um ensinamento moral ao delinquente, ao lado de assegurar-lhe o devido enquadramento laborativo com vistas à futura reaquisição de sua liberdade.

Ocorre que a saturação do modelo de bem-estar no plano político-econômico, em compasso com as mudanças culturais observadas no seio social - das quais as conseqüências históricas de Maio de 68 podem ser testemunhas -, foram gradativamente alterando este cenário, e com ele também pôde ser observada uma mudança no susbtrato da proposta ressocializadora com o fito de atualizá-la. Em resumo, o capitalismo havia resistido a um dos últimos "atentados" externos da era moderna, e a manutenção e retomada de suas atividades políticas e econômicas se daria com força renovada.

Nas últimas décadas, porém, a prisão passou a ser compreendida como um instrumento de simples contenção neutralizante destinado a delinquentes apontados como perigosos e reincidentes, mas não apenas a eles, pois também foram afetados grupos de infratores condenados a pequenas penas ${ }^{124}$. E este movimento sensível na forma como os órgãos oficiais e a sociedade passaram a conceber o cárcere foi muito bem captado por D. GARLAND ${ }^{125}$ :

"Em nítido contraste com a sabedoria convencional do período passado, a opinião dominante agora é a de que 'a prisão funciona' não como um mecanismo de reforma ou de reabilitação, mas como instrumento de neutralização e de retribuição que satisfaz as exigências políticas populares por segurança pública e punições duras."

Em período muito curto, portanto, se tornou comum a referência aos valores essenciais da ressocialização não apenas como um ideal impossível, mas, sobretudo, como um objetivo

\footnotetext{
${ }^{124}$ Garland. Op.cit, p. 56.

${ }^{125}$ Idem. p. 59.
} 
inútil, perigoso e contraproducente quanto a seus efeitos e finalidades ${ }^{126}$. As gestões estatais orientadas para o uso hipertrofiado do sistema penal se difundiram como resposta $a d$ hoc à conflitividade social característica do mundo globalizado, a partir de novas correntes políticocriminais que ameaçavam as conquistas garantistas do direito penal obtidas no pós-guerra.

Tal risco, porém, não se manifesta apenas na questão penológica, senão que afeta vários outros campos, como a flexibilização das relações trabalhistas, o livre trânsito de capitais e a pouca regulamentação de parâmetros financeiros, a abertura e a transferência de mercados e tecnologia, isso apenas para mencionar alguns exemplos ${ }^{127}$.

O declínio do ideal de reabilitação foi muito significativo e esta circunstância veio corroborar a tese de que o enquadramento moderno orientador do controle formal do crime, e que resistia por quase um século, estava sendo abandonado. E este dado é importante para a compreensão dos rumos que o controle viria a assumir, na medida em que o seu suporte estrutural e central (a ressocialização ou reabilitação) deixava gradualmente de ocupar a centralidade das práticas e ideologias havidas no cenário criminal.

Assim, "quando a fé neste ideal ruiu, dissipou-se o arcabouço de crenças, valores e práticas sobre o qual a pena moderna foi erigida" ${ }^{128}$. Este cenário foi decisivo para que ressurgissem as propostas adormecidas, mas nunca abandonadas, de sanções retributivas e de justiça expressiva $^{129}$.

\footnotetext{
${ }^{126}$ Idem. p.51.

${ }^{127}$ Prado. Op. cit. p. 170.

${ }^{128}$ Garland. Op. cit, p. 51.

129 Garland (p.52) reconhece que o ressurgimento da idéia de "retribuição justa" passou a assumir o discurso amplamente dominante tanto na Grã-Bretanha como nos EUA, e um conjunto de práticas típicas desta ideologia passaram a permear o sistema criminal destes dois campos.
} 
As concepções punitivas que passaram a angariar os espaços políticos expressavam ideologias lastreadas na necessidade de se "condenar mais e compreender menos" ou, resgatando ao escólio de E. FERRI ${ }^{130}$, declaravam que as condições carcerárias haveriam de ser as mais aviltantes possíveis.

O crescimento dos pseudópodes do cárcere, mais visivelmente diagnosticado no início dos anos 90, parece resultante de uma miríade de fatores, e dentre eles se destaca o próprio crescimento de uma idéia de "desfecho social" para aqueles que, como consignou M. PAVARINI ${ }^{131}$, “foram descartados pelas agências de disciplina social mais brandas." Na sequência, o próprio PAVARINI deixa registrado um resumo do que para ele representam os

${ }^{130}$ Ferri não era partidário da execução de penas corporais, aflitivas e humilhantes, como ele mesmo afirmava. Contudo acreditava que a experiência no cárcere, afora estas possibilidades - se é que sobra algo - não deveria proporcionar uma existência cômoda e facilitada a ponto de permitir que o recluso se esqueça das dificuldades e privações que a vida em liberdade impõe à generalidade de "homens honestos" (Ferri. Op. cit. p. 348). É dizer: Ferri não defendia excessos, ao menos às claras, mas com seus argumentos tergiversantes acabou senão por justificá-las, ao menos por permiti-las ao não proscrever suas práticas. O que o italiano apregoava expressamente era a idéia de "punição exemplar".

${ }^{131}$ Apud, Prado. Op. cit. p. 169. Uma abordagem muito pertinente acerca das razões do encarceramento em massa (overview of word imprisonment) também podem ser encontradas em outro trabalho do criminólogo italiano Massimo Pavarini (El "punto de vista" dominante y la violência institucional: procesos de reencarcelamiento em el mundo. In: Bergalli, Roberto; Beiras, Iñaki Rivera; et al. Violencia y sistema penal. Buenos Aires: Del Puerto, 2008). Dentre os dados estatísticos levantados pelo autor, alguns deles impactantes (como o que apresenta que mais de um terço da população carcerária do mundo se encontra detida em território norte-americano ou em áreas sob a jurisdição das antigas repúblicas soviéticas. A par das razões aparentemente díspares que levaram a estes números, o trabalho consegue costurar o que de comum entre as das esferas sóciopolíticas pode ser levantado para a compreensão do tema), importa ressaltar em breves linhas três hipóteses possíveis acerca desta elevação dos clientes do cárcere na avassaladora maioria dos países. Em primeiro lugar, pontua Pavarini, que o incremento das taxas de encarceramento decorreriam do aumento da criminalidade ocorrida entre os anos 70 e 80, como desdobramento da crise do modelo de bem-estar; ao lado deste dado, a população detida teria crescido em razão do aumento em número e grau de legislação penais mais severas e repressivas; por fim, o aumento das taxas de encarceramento dever-se-iam a uma maior severidade dos mecanismos de controle formal, centrados nos processos de criminalização secundária. $\mathrm{E}$, mais à frente, arremata o Professor de Bologna (p. 131): "Pessoalmente me encontro em sérias dificuldades para explicar o fenômeno. Ao nível intuitivo, uma idéia (certamente ainda não um modelo explicativo) me parece relativamente plausível, isto é, subjetivamente mais convincente do que outras. Pensando bem, as práticas e as ideologias penais e de controle social na história moderna e contemporânea tem conhecido sempre um processo de difusão e expansão que finalmente conduz (no sentido de que adquire) o ponto de vista dominante (que é tal porque se desenrolou nos países hegemônicos) sobre a questão criminal. A mesma invenção penitenciária do século XVIII, nascida no contexto das primeiras economias capitalistas e vinculada profunda e estruturalmente e este modelo econômico, se impôs rapidamente em todo o mundo, pelo qual hoje, todavia, assistimos com certa maravilha a edificação de cárceres panópticos na India do século XIX e em alguns países do Caribe e da África, naquele tempo dominados por relações de tipo feudal. Logo, a etapa de alternatividade a pena detentiva, fortemente dependente, em alguns contextos nacionais do ocidente, a políticas de welfare, se difundiu logo por todas as partes, inclusive por onde não houve e nem sequer se conheceu um fantasma de Estado Social." 
fatores explicativos da mudança no aparelhamento do controle social, e que não tem respostas diretas na ampliação do sistema penal, mas que este fato opera no plano das consequiências do fenômeno e não das causas.

"Mais ou menos cárceres no mundo (um mais ou menos, repito, apreciável mais simbólica do que materialmente) não parece ter muito a ver com a criminalidade, com a ampliação ou a restrição do número de excluídos do trabalho, com as variações nas representações sociais da periculosidade nas grandes periferias do mundo ou, melhor ainda, tem a ver com tudo isso, porém no sentido de que, na presente contingência histórica, o aumento da criminalidade, a difusão da insegurança social, as práticas de exclusão impostas pelo mercado, os novos processos de mobilidade impostos pela globalização, a redução do Estado Social, etc, são apenas elementos através dos quais - in primis o 'Capital' - se constroem, se impõem e finalmente, de forma universal, se difundem numa nova filosofia moral, um determinado 'ponto de vista' sobre o bem e o mal, sobre o lícito e o ilícito, sobre o merecimento de inclusão ou de exclusão."132

Perante as mudanças retratadas e em face da nova configuração imposta pelo controle social pelo qual o cárcere é afetado, se pode notar que na contemporaneidade os sistemas penais em geral têm deixado de lado a utilização do controle penal para fins de ressocialização de seus clientes, passando a complementar o papel de aprofundar a exclusão social - traço característico dos modelos de sociedade para os quais o cárcere tem prestado seus "serviços".

${ }^{132}$ Pavarini. Op. cit, p. 133. Garland (Op. cit, p. 59) lembra que no período de 1973 a 1997, o número de pessoas presas nos EUA subiu mais de 500\%. 
A derrocada do Estado Providência igualmente fez ruir a sustentação de um mecanismo de punição ancorado neste modelo de Welfare State. Assim, se até meados do primeiro quarto do século XX a defesa expressa na vingança ainda se revestia de tabu, ao menos nos discursos oficiais, os anos recentes trataram de realinhar esta premissa ao centro de gravidade do sistema, permitindo que a raiva e o ressentimento públicos se tornassem o substrato mais comum da retórica que escondia a construção legal e as decisões políticas. Soma-se a este quadro o fato de que as atuais políticas de regulação do crime e da pena invocavam um plexo variado de sentimentos públicos. Com isso, a gramática do poder passou a ser escrita de forma altamente emocional, associando a criminalidade não mais a um problema situacional, mas como um enredo que problematiza a todos indistintamente ${ }^{133}$.

A emergência do medo enquanto traço cultural proeminente jogou por terra a antiga humanidade com que eram tratados os assuntos relativos à criminalidade e à execução das penas, para dar lugar a um enredo de caos generalizado onde tudo passou a ser permitido, inclusive a vingança como justificativa legítima de mobilização estatal ${ }^{134}$.

Como bem identificado por GARLAND ${ }^{135}$, “o crime foi redramatizado. A imagem aceita, própria da época de bem-estar, do delinquente como um sujeito necessitado, desfavorecido, agora desapareceu". Hoje, a imagem do criminoso é veiculada em associação a estereótipos

${ }^{133}$ Garland. Op. cit, p. 52.

${ }^{134}$ Neste particular é interessante e pertinente o exemplo retrato em forma de "lenda cultural" no trabalho monográfico de Filipe Knaak Sodré ( $O$ direito penal e a vingança do Leopardo. Porto Alegre: Nuria Fabris, 2011, p.15-16), eis que simboliza a forma como a sociedade, em geral, tem administrado a questão criminal na contemporaneidade. "Diz uma lenda africana que uma vez um filhote de leopardo afastou-se de casa e se aventurou entre uma grande manada de elefantes. Seus pais o tinham advertido para manter distância daqueles gigantescos animais, mas ele não lhes deu ouvidos. De repente, houve um estouro da manada e um elefante, sem sequer vê-lo, pisou no filhote. Pouco depois uma hiena encontrou o corpo e correu a contar aos pais. - Trago notícias horríveis - ela disse. - Encontrei seu filhote morto na savana. A mãe e o pai leopardos deram urros de raiva e desespero. - Como aconteceu? - perguntou o pai. - Diga quem fez isso com nosso filho! Não descansarei até me vingar! - Foram os elefantes - disse a hiena. - Os elefantes? - Disse o pai leopardo surpreso - Você disse que foram os elefantes? - Sim - disse a hiena. - Vi as pegadas deles. O leopardo andou de um lado para o outro, rosnando e balançando a cabeça. - Não, você se enganou - disse por fim. - Não foram os elefantes. Foram as cabras. As cabras assassinaram meu filho! Imediatamente deu uma corrida morro abaixo, irrompeu entre um rebanho de cabras que pastavam no vale e, num ataque de fúria, matou a todas em vingança."

${ }^{135}$ Garland. Op. cit, p. 54. 
de jovens rebeldes, de predadores sociais e de criminosos multi-reincidentes. Desse modo, desde o instante em que o modelo político-social dominante passou a preferir o ideal de neutralização ao de ressocilização, ainda que sem abandonar por completo a esta, o fez com o suporte de um modelo de organização estatal conhecida como Estado Penal ${ }^{136}$.

É verdadeira a afirmação de que o conteúdo ressocializador e as justificativas que contribuíram para que ele tradicionalmente vagasse tranqüilo no seio da criminologia administrativa $^{137}$ sofreram sérias turbulências no cenário da contemporaneidade penal. Se outrora a base solidária e pietista da qual se valia a ressocialização representava um mote social, lugar comum de práticas que transcendiam ao próprio cárcere, as mudanças que passaram a ser experimentadas pela sociedade - e que importantes autores da teoria social como Z. BAUMAN associam ao fenômeno da globalização - promoveram um afastamento e frivolidade nas relações humanas a partir da valorização material e competitiva das potencialidades individuais.

O ensimesmamento dos indivíduos e o desinteresse pelas pautas de foro público significaram uma igual indiferença para com o outro, desinteresse ainda mais patente quando este outro era alguém que interferia nos cânones mais preciosos do tempo histórico: a propriedade e o consumo. A guinada observada a partir da década de 70 ajuda a compreender o quanto as mudanças culturais foram sendo sintetizadas pelos ideários da ressocialização, mas ainda não foi possível entender como tal processo ocorreu de dentro do conteúdo. Por isso, a análise social (externa) deveria ser complementada pelas transformações endógenas que exigiram mudanças da própria idéia, a fim de que resistisse às inflexões sociais e, de forma renovada, se mantivesse viva nas práticas penitenciárias atuais.

\footnotetext{
${ }^{136}$ Prado. Op. cit, , p. 170.

${ }^{137}$ Para um estudo acerca da construção teórica em torno do conceito de criminologia administrativa Cf. Young, Jock. From inclusive to exclusive society. Nightmares in the European Dream. In: Ruggiero, Vincenzo; South, Nigel; Taylor, Ian. The new european criminology. Crime and social order in Europe. Londres : Routledge, 1998, p. 77 et seq.
} 
Assim, após a empreitada de apresentar o arrimo social a partir do qual a idéia de ressocialização se tornou possível e efetivamente exequível na seara da político-criminal, restou claro que a elasticidade de seu conceito e a adaptabilidade de seu conteúdo aos cambiantes interesses de cada época favoreceram sua constante reinvenção na qualidade de justificativa viável à reforma dos que eram capturados pelas redes penais.

A gradativa perda de espaços políticos aptos a viabilizar, como outrora, o funcionamento dos mecanismos de intervenção penitenciária sob as orientações ressocializadoras impôs dois importantes desdobramentos: por um lado, a redução do conteúdo conceitual mais tradicional, ligado intrinsecamente aos valores positivistas; por outro, a tentativa de escapar da herança positivista, com a abertura do conceito e a tentativa, ainda que a meio caminho, de trazer o tema da co-responsabilidade social pela recuperação do criminoso.

\subsubsection{Premissas políticas e filosóficas do conceito de ressocialização}

$\mathrm{Na}$ essência, as modalidades de intervenção no criminoso (cenário em que o ideal de ressocialização figura) são inspiradas por uma arbitrária imagem de homem pré-configurada, edificada antes mesmo do evento tido como um desvio ou problema de ordem penal. Assim, por exemplo, a tese do tratamento penitenciário parte de uma imagem de um homem em si mesmo delinqüente, ou seja, portador de uma personalidade predisposta ao cometimento de atos considerados como crimes.

Trata-se de um indivíduo atávico e perigoso, desconectado do estágio de civilização alcançado pela sociedade ordeira. Neste horizonte, como lembra GÁRCIA-PABLOS ${ }^{138}$, “a eventual reincorporação daquele na sociedade não é uma meta nem um objetivo, senão uma conseqüência derivada da prévia inocuização do delinquente que deixou de ser perigoso".

${ }^{138}$ Gárcia-Pablos. Op. cit, p. 671. 
A premissa mais tradicional da ressocilização, baseada nos preceitos correcionalistas, considera a imagem de um homem inválido, incapaz de autodeterminar-se em razão de uma debilidade em seu querer e, portanto, carente de ajuda. O criminoso passa a ser visto, então, ora como louco ora como criança. A pena, aqui, passa a exercer uma função pedagógica, a fim de restabelecer o equilíbrio entre a ação individual e os preceitos de ordem moral vigentes no contexto social. Há, portanto, uma deficiência na base do processo de internalização das normas e a punição se prestaria a fornecer uma assistência para que o delinquente pudesse aprender a linguagem dos demais cidadãos ordeiros e, com isso, plenamente alfabetizados com a simbologia imposta pelas normas penais.

Não faltaram argumentos para justificar a intervenção no homem desviado que, então, passaram a ancorar-se na incapacidade (que levaria ao tratamento) ou na deficiência (que levaria à ressocialização) de socialização dos criminosos ${ }^{139}$. A diferença entre as conotações repousaria, ao lado das considerações a respeito do homem desviado, nos horizontes próprios da etiologia do delito. E isto indicaria o locus a ser trabalhado por meio da ressocialização ou do tratamento penitenciário: se o diagnóstico da etiologia criminal apontasse para uma socialização inapropriada, haveria de laborar a pena; por outro, em se tratando de uma socialização comprometida não por uma debilidade convivêncial, mas em razão de aspectos intrínsecos, a socialização haveria de ser originariamente edificada (quando possível) no cárcere.

Em outras palavras, a legitimidade do sistema se explicaria em razão da contenção dos intrinsecamente inaptos, por um lado, e na catequização aos debilitados (e recuperáveis) por

\footnotetext{
${ }^{139}$ Borja Caffarena (Desviación y resocialización. Cuadernos de Política Criminal. n.23, 1984, p. 387) tentou situar o tema da socialização em torno de um conceito, segundo o qual "o processo de socialização se apresenta como um continuит. Tem sua origem no início da infância, dentro das relações familiares, para prosseguir na escola, na rua, na fábrica etc. A socialização deve ser compreendida como mudanças na forma de atuar do sujeito e que podem se manifestar com maior intensidade em determinados momentos da vida, porém não se interrompem jamais".
} 
outro, como formas intervenção calcadas sobre a premissa vaga e acrítica de que o réu teria um código valorativo distinto daquele aceito na sociedade ${ }^{140}$.

A teoria da socialização, dessa forma, tenta explicar o delito como desdobramento de um transtorno ou déficit nos processos de interação ou socialização a que foi submetido o delinquente. Este aparace, então, como um indivíduo a meio caminho do processo de desenvolvimento social e, portanto, alheio às pautas valorativas vigentes (dominantes). Como pronunciou T. Miralles ${ }^{141}$, não deixa de se tratar de uma proposta enrustida de se exercer um saber clínico sobre o condenado, a fim de despersonalizá-lo sob o rótulo de mais um "caso", a fim de assentar unicamente nele as mudanças pretendidas.

A expectativa para os apoiadores da tese da socialização precária é a de que, como lembraram FIGUEIREDO DiAS \& COSTA ANDRADE ${ }^{142}$, a resposta ao crime deve privilegiar as medidas (essencialmente terapêuticas e pedagógicas) capazes de des-condicionar o delinqüente do comportamento criminoso e re-condicioná-lo em formas de conduta socialmente desejadas ou toleradas. Assim, a partir de uma perspectiva correcionalista, o sistema penal se põe a realizar uma transformação qualitativa no sujeito, tendente a atingir a vontade viciada que o teria levado ao cometimento do delito. Assim, a função do direito penal deveria se revestir de um caráter pedagógico e tutelar, no sentido de promover uma autêntica "cura de almas"143.

ROBERTO BERGALLI, partindo de uma perspectiva criminológica interacionista, entende a socialização como o conjunto de processos a que se submete um indivíduo quando é

\footnotetext{
${ }^{140}$ Esta afirmação pode ser encontrada expressamente no texto em que Cezar Bitencourt (Criminologia crítica e o mito da função ressocializadora da pena. In: Tratado de direito penal. Vol I. 13 ${ }^{\mathrm{a}}$ ed. São Paulo: Saraiva, 2008, p. 103) escreve acerca do mito da ressocialização em face das orientações crítico criminológicas. Ocorre que na tentativa de adotar um discurso crítico, ora de viés marxista, ora de caráter puramente administrativoconservador, o reconhecido penalista gaúcho acaba por legitimar as práticas que, no geral, luta por proscrever sob a rubrica de "mitos" da pena.

${ }^{141}$ Miralles. Op. cit, p. 105.

142 . Figueiredo Dias \& Costa Andrade. Op. cit, p. 216.

${ }^{143}$ Gárcia-Pablos. Op. cit, p. 659.
} 
introduzido numa realidade de convivência de grupo. Nas palavras do autor, este conjunto de experiências socializantes pode ser assim resumido ${ }^{144}$ :

"Na socialização primária o indivíduo aprende a realidade objetiva da sociedade em que vive, procurando um contato sensível por meio das definições consensuais e dos limites 'morais' desta sociedade. Logo se empreende uma socialização secundária, que resulta na introdução dos numerosos grupos que existem no interior da sociedade, com suas realidades próprias e ao mesmo tempo diferentes entre si (...). A pessoa experimenta as definições objetivas de muitas outras pessoas e organismos que outorgam maior significação a algumas delas, ao passo que excluem relativamente outras. Tais definiçõos (etiquetas) que a pessoa aceita e internaliza a identificam subjetivamente com a realidade objetiva do grupo, incluindo nisso a estratificação que este grupo impõe como marco de regras e normas que há de prevalecer. Assim, supõe-se que tais internalizações se tornem objeto de 'renegociação', constituindo uma constante fonte de conflitos quando aparecem realidades alternativas, apresentando uma situação precária e inconsistente para o 'si mesmo'. O certo é que a socialização exitosa somente tem lugar quando prevalece a harmonia entre o 'si mesmo' do indivíduo e os distintos 'significantes' (símbolos) de seus semelhantes ou com os 'significantes' generalizados (da sociedade como um todo), ou seja, o equilíbrio entre a realidade subjetiva e a objetiva".

Para o criminólogo espanhol, consequentemente, a construção do "si mesmo" se desenrola mediante várias experiências socializantes, dentre elas as que a psicologia social passou a denominar de socialização primária. Mas não é somente esta vivência originária a responsável

${ }^{144}$ Bergalli. Op. cit, p.206. 
pela edificação do "eu", senão que neste cenário também interferem decisivamente (seja de maneira positiva ou negativa) os processos de socialização secundária e ressocialização.

Em suma, as conotações relacionadas à teoria da socialização perseguem objetivos funcionais de adaptação do indivíduo ao grupo, considerando uma lógica axiologicamente neutra e uma disponibilidade de interação recíproca entre a sociedade e o indivíduo. Ao lado das teorias em torno da socialização, lembra GÁRCIA-PABLOS ${ }^{145}$ que outras teorias, ligadas mais intimamente às idéias de correção e à emenda do indivíduo, se pautariam por trilhas ainda mais ambiciosas, voltando seus aportes para a pedagogia em torno de valores apriorísticos e inquestionáveis. E o autor espanhol ainda destaca que neste plano ${ }^{146}$

“a ressocialização implica um processo de 'aprendizagem' e de 'interiorização' de valores que se percebem e aceitam como tais por parte da sociedade e do indivíduo. Tem, pois, um fundamento moral e valorativo (axiológico), além de um mecanismo particular de aprendizagem e asseguramento (pedagógico)”.

L. DE BRAY ${ }^{147}$, por exemplo, ingressa no campo das pressões sociais para compreender a dinâmica criminal. E, neste horizonte, a autora belga estabelece que o criminoso apresentaria uma capacidade reduzida de resistência às pressões, ou seja, seria mais suscetível a tais interferências e provações. Perante este quadro, o tratamento penitenciário (utilizado por ela de forma abrangente, subentendendo tanto o tratamento penitenciário quanto a ressocialização, que ela prefere chamar de "tratamento social") teria o objetivo de ampliar as resistências do indivíduo, reduzindo, por um lado, a vulnerabilidade perante as pressões exteriores e, por outro, reforçando a personalidade deteriorada. E na linha traçada pela

\footnotetext{
${ }^{145}$ Gárcia-Pablos. Op. cit, p. 662.

146 Idem, p. 646.

147 Bray. Op. cit, p.126. Na realidade, ao se falar das infindáveis justificativas que se atribuem ao tratamento ressocilizador, inclusive garantindo créditos que nunca conseguiria realizar, tal como a redução da vulnerabilidade através do encarceramento, os autores buscam reproduzir e perpetuar o conceito sob as vestes de um instrumento revolucionário e transformador.
} 
assistente social belga, "o objetivo final dos tratamentos penitenciários (e, como se verá, também dos tratamentos pós-penitenciários) é o de influir sobre o comportamento dos delinquentes." 148

Como se depreende do exposto, um dos argumentos que impõem a derrocada dos ideais ressocializadores estaria no fato de que a necessidade de um modelo de referência bem definido e que sirva de parâmetro axiológico para os desviados seria uma utopia numa sociedade democrática e pluralista. E, na ausência desta base, soçobrariam as pretensões ressocializantes. Neste cenário marcado pela conflituosidade social e pela divergência de concepções, ideologias e estilos, a "seleção" dos conjuntos normativos que passariam a integrar o modelo de conduta desejadas emergia como fruto de uma mera imposição arbitrária, com o escopo de exercer a manipulação do indivíduo.

Em verdade, sobram vozes que afirmam ser o termo ressocialização tão somente a expressão oficial conferida pelo Estado para intervir de forma desmedida no campo da execução penal, pois se, de um lado, ostenta uma idéia de oficialidade e equidade, pode representar uma idéia por demais vaga e enganosa, de outro - justificando qualquer penduricalho que se queira forjar no campo da execução penal. E decifrar os seus tão variados conteúdos tem se tornado uma laboriosa tarefa de caminhar por um "túnel sem fim". 149

Os programas terapêuticos e pedagógicos promovidos no cárcere refletem o funcionamento social ainda sob a influência modelo de bem-estar social, eis que o objetivo de tais programas era o de integrar todo o tipo de dissidência, de desvio. Assim, o delito, então entendido como desviação máxima e nociva à manutenção da perfeita engenharia social, haveria de ser concebido como uma prova de distúrbio mental puro, ou de transtorno que implicasse debilidade de internalização normativa ou de resistência às pressões sociais, de tal modo que

${ }^{148}$ Idem, p.128.

${ }^{149}$ Gárcia-Pablos. Op. cit, p. 649. 
sua compreensão haveria de se socorrer do saber clínico ou biopsicosocial ${ }^{150}$. E assim, a conflituosidade social passou a se tornar um tema afeito à semiologia médica, psicológica e assistêncial.

A introjeção dos aportes teóricos pela política-criminal levaram a que o capítulo referente à recuperação do criminoso privilegiasse o trabalho como terapêutica mais destacada - o que representava uma dupla vantagem: de anestesiar a opinião pública legitimando o cárcere como um instrumento dignificante, e o de favorecer a lógica de mercado ao oferecer mão-deobra barata e docilizada. As prisões, sob esta perspectiva transformar-se-iam em verdadeiras oficinas, em que o trabalho era antes de tudo mecanismo para a internalização da disciplina e da obediência, e apenas subsidiariamente meio de subsistência ${ }^{151}$.

O trabalho deve, neste contexto, ser compreendido como o fundamento da vida penitenciária, e a ele se empresta uma pluralidade de finalidades, dentre elas a indenização ao erário público e às partes pelo crime, a educação moral do delinquente e sua adaptação higiênica; e este pensamento já era professado por ENRICO FERRI, um dos mais reconhecidos discípulos de C. LOMBROSO. Em resumo, para Ferri o trabalho se apresenta como o instrumento mais eficaz e seguro na trajetória da preparação do recluso ao retorno à vida em liberdade ${ }^{152}$.

CAROLINA PRADO lembra, de forma bastante pertinente para a ocasião, que o milenar mandamento bíblico que havia "condenado" ao trabalho o homem expulso do paraíso parece servir como norte interpretativo para as práticas punitivas dos dias atuais, pois "a bíblia laica

\footnotetext{
${ }^{150}$ Miralles. Op. cit, p. 105, nota de rodapé n.6. Ainda sobre a relação entre o trabalho e a educação com as premissas positivistas, Cf. Filippi, Leonardo; Spangher, Giorgio. Diritto penitenziario. Milão: Giuffré, 2000, p. 17-23.

${ }^{151}$ Rauter. Op. cit, p. 63.

${ }^{152}$ Ferri. Op. cit, p.347.
} 
das leis de mercado" tem destinado justamente a atividade laborativa ao homem expulso do paraíso das leis tuteladas pelo velho Estado de Bem-Estar Social. ${ }^{153}$

O discurso que ali legitimava as práticas ressocializadoras passou, enfim, a contar com um novo elemento, ao lado dos argumentos de índole clínica: o trabalho como forma de libertar o homem dos demônios da indisciplina e da miséria.

\begin{abstract}
"A indisciplina e a ociosidade geram a miséria, que é por sua vez o gerador numero um da criminalidade. Nada melhor, para o combate ao crime, que combater o ócio e a indisciplina, tanto na sociedade como um todo quanto na prisão, enquanto micro-sociedade. $\mathrm{O}$ meio privilegiado para o aprendizado da disciplina, do respeito à lei, da obediência, é justamente o trabalho."
\end{abstract}

A prisão como espaço terapêutico passa a ser constantemente compreendida como espaço peculiar, porém favorável, ao exercício laborativo. O trabalho, compreendido como a chave do processo de reinserção social, tanto se prestaria a desonerar o cárcere da ociosidade dos detentos quanto teria o seu papel de planificar as expectativas de mercado naqueles que não gozaram de uma inclusão laboral adequada e, por isso, não raro são marginalizados.

\footnotetext{
${ }^{153}$ Prado. Op. cit, p. 166.

${ }^{154}$ Rauter. Op. cit, p. 63. Como chama a atenção Rauter (p. 103), “o trabalho prisional atende, além disso, a muitos interesses para além da 'recuperação' do preso. No cárcere tudo se converte em um bem negociável e isto também ocorre com as oportunidades de trabalho. Muitas vezes uma ocupação é o premio para uma caguetagem, a oportunidade de estar mais próximo da administração e com isso obter certas vantagens, como o acesso mais fácil ao mundo lá fora, uma classificação melhor de comportamento, proteção contra os inimigos na cadeia, alimentação melhor, etc. (...) Mas o que queremos ressaltar é que o trabalho é algo a ser compreendido no jogo das múltiplas forças institucionais: a possibilidade de trabalhar é vista pelo preso como um privilégio, em virtude dos benefícios secundários que acarreta. Além disso, ela é um imperativo, do ponto de vista da preservação da sanidade mental, para alguém mantido em confinamento por longos anos. Este talvez seja o único 'lucro' do preso que trabalha: a preservação de sua saúde psíquica."
} 
Ainda segundo T. MiRALles, os diversos estudos realizados a respeito dos trabalhos oferecidos nos cárceres, e que seriam indicadores de ineficácia de tais propostas, conduzem para as seguintes características: escassez de instrução laboral; impossibilidade de escolher algum tipo de trabalho mediante aptidão pessoal do preso; falta de meios para se completarem ou se iniciarem os estudos; carência ou ineficácia dos órgãos penitenciários para assegurar um acompanhamento laboral aos egressos do sistema. E arremata a autora:

"O mundo laboral do preso tem características muito distintas das que ele encontrará após sua saída do cárcere. O trabalho que se realiza no cárcere é tipicamente carcerário, não guarda nenhuma relação com a produção de tipo industrial que impera na sociedade. Ao mesmo tempo, no mercado de trabalho se exige cada vez mais especialização, pelo que um trabalho como braçal não lhe dará acesso a um verdadeiro ofício que lhe possa ser útil (...)". ${ }^{155}$

A relação desvio-cárcere-trabalho-adequação estaria na base dos recentes argumentos adotados em prol da manutenção do ideal ressocializador nos tempos atuais. A simplificação com que se lêem os movimentos laborativos no cárcere, sobretudo quando os associam a um benefício do preso e não a um direito que lhe deve ser assegurado, faz com que a sanção seja socialmente concebida como algo bom, ou "dos males o menor".

Não restam dúvidas de que no modelo de sociedade do consumo vigente o trabalho desempenha um papel de inserção, tanto material quanto simbólica, e possibilitar que ele se desenvolva no cárcere não é um mal, senão que uma necessidade. Ocorre que a forma como em geral o trabalho carcerário é oferecido (quando isto ocorre) tem corroborado a tese de que sua prestatividade é muito mais a de manutenção da exclusão social pretérita ao cárcere do

${ }^{155}$ Miralles. Op. cit, p. 111-112. 
que de macanismo de emancipação - tal como alardeado e introduzido "goela abaixo" pelos Órgãos oficiais.

Assim, a simplificação da realidade do crime, a fim de atender aos reclamos urgentes do consumo, leva à tranqüila conclusão de que o comportamento desviado de interesse penal se consubstanciaria numa transgressão cuja causa repousaria na inabilitação do indivíduo de internalizar as pautas de conduta prescritas nos textos legais. Portanto, a conduta criminosa sugeria uma séria incapacidade de convivência em sociedade, demandando então a aplicação da pena a fim de ensinar aos detentos as regras do funcionamento mercantil e a lógica do lucro. E com este enredo social, a ressocialização ou ideologia do tratamento ressocilizador foi se perpetuando.

Ocorre que as mudanças sociais iniciadas na década de 70, e cujo apogeu se deu com a queda do muro de Berlim em 1989, tal como levantadas alhures e em grande medida impostas pelos processos de globalização e exarcebação do consumo e da competição, foram nocivas às propostas ressocializadoras e exigiram delas uma reinvenção para não serem por completo banidas do cenário político-criminal.

Se no apogeu destas idéias, como ressaltou HOHMEIER ${ }^{156}$, o ideal ressocializador se apoiava na premissa de que o sistema penitenciário moderno optou pela socialização em detrimento da segurança e, com isso, passou a privilegiar o fim de reeducação da pena frente à expectativa de simples inocuização do criminoso, a história estava denunciando uma mudança de enfoque. Tanto é assim que numa comparação entre as perspectivas da segurança e da saúde (que não deixa de ser um desdobramento da assertiva de natureza socializante exposta por HoHMEIER), Alvino AUGUSTO DE SÁ ${ }^{157}$ retratou não apenas a sua observação empírica, senão

${ }^{156}$ Apud, Cervini. Op. cit, p.32.

${ }^{157}$ Sá, A. A. de. Transdiciplinaridade e responsabilidade da academia na questão penitenciária. In: Sá, A.A. Criminologia clínica e psicologia criminal. São Paulo: RT, 2007, p. 173. Neste sentido, de acordo com T. Miralles (Op. cit, p. 105-106), "Para o funcionário, a única razão para a condenação é o castigo do delinqüente e 
que acabou por apresentar uma paisagem que se reproduzia, sem grandes diferenças, nos espaços penitenciários contemporâneos: “A segurança era questão prioritária e tudo girava em torno dela, em função dela. O primeiro preceito, o primeiro quesito a ser respeitado, para se realizar qualquer trabalho, para o preso exercer qualquer atividade, era o da segurança."

Este momento de recrudescimento do controle e declínio do previdenciarismo penal, como cunhou D. GARLAND, acarretou um retorno aos argumentos meramente retributivistas da pena, colidindo com as propostas de reformatórias pugnadas pelo ideário ressocializador. O cárcere passou a ser concebido como espaço de neutralização, e este fato foi impulsionado, dentre outros fatores, pela crise fiscal do Estado - desejoso de cortar as verbas destinadas aos programas reabilitadores, a fim de que fossem reordenadas para campos de maior apelo político - e pelos resultados pouco expressivos a respeito de sua eficácia programática. E este foi o cenário em que se iniciou um movimento de flexibilização da ressocialização, que para não ser plenamente esquecida, aceitou ocupar apenas parte do espaço administrativo que antes dominava. E este tem sido o caminho de sua identificação na forma de uma ressocialização soft, ou seja, de conteúdo mínimo mas que, ainda assim, guarda suas marcas originais inabaladas.

a vigilância completa para que ele guarde a mais absoluta obediência, e quando, em razão da ressocialização, são necessárias as presenças de indivíduos alheios ao mundo custodial e que poderiam obter prerrogativas até mais importantes que as deles, dito corpo viu chegar ao fim os dias de poder e, especialmente, de impunidade. Aos psiquiatras e psicólogos, como também aos assistentes sociais, se foram minando as prerrogativas que os programas lhes aviam proporcionado, e pouco a pouco todos aqueles cujo trabalho era visto como inovador foram cooptados pela força dos funcionários. Somente perduraram aqueles que cooperaram abertamente com as premissas de vigilância e castigo, os que subordinaram seu tratamento às exigências de vigilância e custódia". Ainda sobre o autoritarismo e impunidade dos técnicos e servidores penitenciários e, consequentemente, a refração aos trabalhos com foco na ressocialização Cf. Neuman, Elías. Prisón, La inhumanidad de lo humano. Pensamento Penal Del Sur. v. II, 2006. 


\subsubsection{Cenários teóricos contemporâneos da ressocialização}

O ideal ressocializador passou por adaptações em razão das novas respostas punitivas fornecidas pelo sistema penal contemporâneo. A escassez de recursos para a implementação de programas mais ambiciosos voltados à reforma moral dos criminosos, a redução no quadro técnico e, sobretudo, a perda de legitimidade política da reabilitação obrigaram a sua reinvenção, que passou a se expressar em tons menos pretensiosos.

Em meio ao quadro de violências explícitas observadas sob a chancela de olhares retribucionistas que vem angariando cada vez mais espaços nos órgãos de poder, a ressocialização se esgrima como um paradigma de resistência, que, apesar de todo o seu histórico de dominação, paradoxalmente se vê como mecanismo de contenção de opressões ainda maiores e mais vis do que aquelas afiançadas em suas propostas de fonte correcionalista. No cenário de guerra em que se transformou a realidade carcerária, as premissas ressocializadoras se tornaram mecanismo hábeis a assegurar o que resta de humanidade aos detentos, ainda que por meio de seus métodos mais tradicionais, como o trabalho e a educação formal.

A aceitação da idéia de ressocialização, neste horizonte sombrio, se encontra atrelada ao fato de que, ao menos, ela invoca uma execução penal mais humana, a ponto de evitar males desnecessários aos já inerentes à punição em si mesma considerada. Assim, nas palavras de H.J.KERNER ${ }^{158}$,

"um procedimento de execução que não ofereça socialização nem tratamento significa desumanização e retrocesso, porque na maioria dos casos o tratamento não deve ser entendido

\footnotetext{
${ }^{158}$ Apud,Gárcia-Pablos. Op. cit, p. 663.
} 
no sentido terapêutico estrito, senão simplesmente como atenção de caráter genérico, assistência social e prestações caritativas".

No mesmo sentido, o criminólogo alemão KARL PETERS ${ }^{159}$, advertiu que a ressocialização é, tão somente, uma alternativa ao retribucionismo, e o seu não reconhecimento ou os apontamentos acerca de seu fracasso teriam o condão de contribuir para um retrocesso no campo punitivo capaz de fazer da pena um instrumento meramente vindicativo e expiatório como outrora.

Na visão de BRUNO RIBEIRO, a nova concepção da função de reintegração social ou ressocialização (o autor estabelece uma relação de sinonímia entre os termos) estaria assentada na inadmissibilidade de propostas baseadas na reforma da personalidade do recluso. E arremata: a realização da idéia de ressocialização deve ocorrer através do oferecimento aos reclusos da possibilidade de participação nos diversos programas implementados no cárcere, e desde que manifestem a voluntária adesão para tanto ${ }^{160}$. E esta proposta, de respeito à vontade do recluso de aceitar ou não os programas ressocializadores é o que se convencionou chamar de conteúdo ressocializador mínimo ${ }^{161}$.

${ }^{159}$ Apud, Gárcia-Pablos. Op. cit, p. 646. O próprio autor se posiciona, ao final de seu trabalho, neste sentido, e afirma: "O ideal ressocializador, apesar de suas ambiguidades e contradições, apresenta um saldo muito favorável. Sobretudo aquele que tem contribuído para superar e banir as doutrinas absolutas da pena e apontar novos caminhos para a função penal”. (Pablos, p. 675)

${ }^{160}$ Ribeiro. Op. cit, p. 115.

161 Gárcia-Pablos (Op. cit, p. 656-657) expõe em seu trabalho inúmeras críticas formuladas ao conceito de ressocialização e, ao final do texto, se posiciona assumindo que tal conteúdo ainda pode resistir, mas com uma condição, desde que se atribua um conteúdo mínimo, no sentido de execução humanitária da pena. Na sequencia, o criminólogo espanhol tratou de explicar o que seria conteúdo mínima e máximo na esfera da ressocialização: "O programa ressocializador pode ser dirigido, em termos de uma relativa neutralidade valorativa, a 'adaptação' do indivíduo às estruturas e pautas sociais; isto é, pode conceber-se 'funcionalmente'; ou bem pode pretender uma 'correção', 'melhora', 'reeducação' do delinqüente, que se entende, como é lógico, desde uma determinada escala de valores. Ainda que uma distinção drástica entre uma e outra concepção não seja possível, cabe apreciar nas diversas posturas doutrinárias a maior acentuação do aspecto funcional ou do valorativo. A teoria da 'socialização' e a 'correcionalista' (Besserungstheorie) poderiam corresponder à fundamentação funcional e a valorativa, respectivamente". 
ESSER $^{162}$ propõe uma interpretação possível para a ressocialização, ou uma forma de minorar suas incongruências e incompletudes sem abandonar o conceito, mas, concomitantemente, conferindo a ele um caráter efetivamente humanístico, conhecido doutrinariamente como terceira via ou "pedagogia da autodeterminação". Há na tentativa de ESSER uma clara intenção de oxigenar as práticas havidas no cárcere, o que já representava um avanço dados os fins que a proposta almejava. Nesta esteira, é possível situar a proposta lançada pelo autor como uma precursora da reintegração social - tema a ser explorado no capítulo seguinte.

A idéia plantada por ESSER serviria como alternativa entre os dois modelos já consagrados de ressocialização: a ressocialização para a legalidade (conteúdo mínimo) e a ressocialização para a moralidade (conteúdo máximo). Para ESSER, a ressocialização não haveria de fornecer conteúdos morais ou valorativos concretos ou circunscritos a um grupo, mas sim oferecer ao recluso os caminhos e possibilidades existentes numa sociedade heterogênea e plural, a fim de que as escolhas viessem a representar um reflexo de autonomia e não de imposição ou domesticação.

A postura de ESSER indubitavelmente demonstra um avanço quando comparada às tradicionais abordagens existentes no cenário da ressocialização. Não há como negar que a pretensa liberdade valorativa como marca dos processos propostos pela "pedagogia da autodeterminação" refutam a idéia de forjar cenários prontos sem, contudo, abrir mão do consenso acerca das regras do jogo social preconizadas pelo direito. Sob esta análise, não há como negar o aspecto funcionalista da proposta, o que não pode ser razão para descredenciar os ganhos teóricos e práticos que ela aquilata.

Também HAFKE ${ }^{163}$ chegou a sugerir um modelo de ressocialização mais distante da domesticação ideológica característica das propostas tradicionais, e chamou de "terapia

\footnotetext{
${ }^{162}$ Apud, Gárcia-Pablos, p. 668.

${ }^{163}$ Apud, Pablos, p. 668.
} 
social emancipatória” o processo de conferir ao apenado condições para compreender os problemas derivados do convívio social sem, contudo, deixar de respeitar a sua autodeterminação.

G. KAISER ${ }^{164}$ ressalta que todo programa ressocializador tem por escopo integrar o indivíduo no mundo de seus concidadãos e, antes disso, nos cenários sociais básicos, como a família, a escola, o mercado de trabalho; com isso, quer-se favorecer que o delinquiente possa sair do contexto de segregação para voltar a assumir seu papel e responsabilidade na sociedade. E arremata, de forma muito lúcida, que esta perspectiva necessita da colaboração e da corresponsabilidade de toda a sociedade: "a sociedade, beneficiária do esforço de seus cidadãos, não pode se esquecer da sorte de seus apenados nem ignorar a sua parcela de culpa; antes, deve comprometer-se com eles e oferecer-lhes perspectivas esperançosas de uma vida humana em liberdade".

Claro que as propostas acima descritas são passíveis de críticas. De fato, há quem sustente a impossibilidade de se articular uma "pedagogia da autoderterminação" através da autoderterminação (no sentido de não haver determinação livre à base da pedagogia, pois aí haveria heteronomia no lugar de autonomia), ou uma 'terapia social emancipatória' alheia a referencias concretas de valores ou modelos.

Por esta perspectiva, todo processo educativo ou pedagógico implica necessariamente uma imposição, ainda que mais sutil e refinada ${ }^{165}$. Ainda assim, ousamos vislumbrar estas propostas como orientações mais avançadas e, sobretudo, preocupadas com o homem. E, se não conseguiram se afastar mais das margens da dominação, isto se deu menos pelo teor do projetos do que pelo local em que eles foram preconizados. O cárcere é uma máquina de

\footnotetext{
${ }^{164}$ Idem. Ibidem.

${ }^{165}$ Neste sentido é a crítica de Gárcia-Pablos. Idem, p. 688-689.
} 
dominação, e qualquer tentativa de minorar esta influência conferindo protagonismo, por menor que seja, ao cidadão antes mesmo do criminoso, já merece consideração.

O italiano GIUSEPPE BetTiol também foi um vanguardista, um pioneiro de sua época, na medida em que buscou superar o hermetismo das propostas então estabelecidas no contexto da ressocialização, sobretudo quando se tratava de forjar um conteúdo moral de máxima intensidade, buscando com isso superar o quadro de dessocialização em que se encontravam os reclusos.

Se é certo que, por um lado, BETTIOL abriu trincheiras ao possibilitar a abertura do conceito de ressocialização, por outro, restou seu labor limitado ao estado da arte em que estava imerso, e isto se aplica aos demais autores citados. É dizer, foram eles tributários do estado da arte em matéria penal, como haveria de ser, mas deixaram lições que resistiram e foram decisivas para a evolução do tema. Assim, consignou BETTIOL ${ }^{166}$ que

"o homem tem a liberdade de fazer o bem, mas é também livre para fazer o mal e persistir no mal, sujeitando-se a sofrer as conseqüências do mal perpetrado. Ninguém pode obrigar o homem ao bem, porque nesse caso a ação perderia o seu mais preciosos significado moral. Ninguém está autorizado a penetrar no íntimo da consciência humana, para procurar imprimir-lhe uma certa orientação. O sacrário da consciência é inviolável, e nem o fato de ter sido condenado pode autorizar o Estado (um não valor) a estabelecer leis que possam valer para a consciência de um valor, como sempre, em qualquer situação e em qualquer caso, o homem continuará a ser. É ele o árbitro de sua orientação e não pode ser obrigado a ação, nem pode ser constrangido à virtude".

\footnotetext{
${ }^{166}$ Apud, Ribeiro. Op. cit, p. 110-111.
} 
G. BetTiOL foi orientador do não menos consagrado criminólogo italiano ALESSANDRO BARATTA, e por certo exerceu influência no pensamento deste autor. Contudo, tal como os autores mencionados, Bettiol não avançou para além da ressocialização, como os demais autores trabalhados. E por mais que tenham avançado no conceito de ressocialização, os horizontes do conceito não chegaram a ultrapassar as barreiras do cárcere, é dizer, não subsistiam independentemente dele mas, por oposto, se nutriam da existência do aparelho penitenciário.

Não há como negar que muito mais do que as repetidas teses acerca da ressocialização foram produzidas. A literatura demonstra que a teoria avançou e forneceu condições para que os órgãos oficiais pudessem utilizar um conteúdo mais libertário, se assim o quisessem. Mas este reconhecimento de algo positivo num universo tão sombrio não implica reconhecer que tais propostas se tratem de reintegração social.

E esta confusão, por assim dizer, tem sido um fator determinante para o avanço da discussão e para que ela busque, contra vários prognósticos, atenuar o discurso de vingança e neutralização que atualmente orienta o debate público acerca do cárcere, e em especial do que fazer com os encarcerados. GÁRCIA-PÁBLOS foi muito feliz ao concluir seu trabalho nesta perspectiva, qual seja, de avançar na idéia de ressocialização, retirando a exclusividade, ou compratilhando a responsabilidade, entre presos e sociedade. E assim afirmou ${ }^{167}$ :

“A ressocialização implica um processo recíproco: sociedadeindivíduo, indivíduo-sociedade de interação, de forma que as pautas e modelos de conduta não se imponham unilateralmente por nenhuma das partes, ao passo que não seria lícito propugnar a ressocilização do

${ }^{167}$ Gárcia-Pablos. Op. cit, p.666. 
indivíduo sem a possibilidade eficaz de questionar e modificar as próprias estruturas sociais."

Dessa forma, Gárcia-Pablos pôs em curso uma idéia renovada de ressocialização. Não há dúvida de que o autor se afasta consideravelmente das origens do ideal reabilitador partilhando as responsabilidades tanto da conduta criminal quanto da execução penal entre presos e sociedade. E este conceito, que parece o que de mais evoluído se tem sob a rubrica ressocialização, precisa ser cotejado com o substrato da reintegração, no interesse de pesquisar similitudes e diferenças que possam colocá-los, criminologicamente, enquanto conceitos sinônimos ou, talvez, em grau de independência. 


\section{HORIZONTES DE TRANSIÇÃO RUMO À REINTEGRAÇÃO SOCIAL: O LIMIAR DO INTERCÂMBIO SOCIEDADE-CÁRCERE}

\subsection{DA IDÉIA DE RESSOCIALIZAÇÃO À RESSOCIALIZAÇÃO DA IDÉIA: DIVISANDO OS LIMITES (E AS DIFERENÇAS) ENTRE AS PROPOSTAS DE RESSOCIALIZAÇÃO E REINTEGRAÇÃo SOCIAL}

Os discursos em torno das propostas e estratégias aplicadas ao cenário penitenciário encontram-se tão desgastados que a simples menção ao tema já é capaz de atrair certa dose de escárnio por parte de quem ouve ou lê algo sobre o tema. É como se o proponente da discussão estivesse alheio ao volume do que já se disse, desconectado do mundo e definitivamente não tivesse a noção de que tudo, absolutamente tudo o que poderia ter sido dito, já o foi.

As alegações surgidas em torno da "questão penitenciária" e, no caso desta pesquisa, das propostas de intervenção direcionadas aos encarcerados, foram penetradas por questionamentos de indiscutível natureza crítica, que apontaram mentiras, equívocos e promoveram importantes desconstruções no campo da filosofia da punição; tudo isso, em geral, sem ingressarem no terreno político-criminal, no campo mais propositivo ou ao menos indicativo acerca do que fazer com as severas criticas alinhavadas. Foi, portanto, uma crítica despreocupada em reconstruir o que era, em tese, demolido e, neste sentido, trazia a marca da filosofia crítica alemã em seu modelo mais original ${ }^{168}$.

\footnotetext{
${ }^{168}$ Fred Rush (As bases conceituais da primeira teoria crítica. In: Rush, Fred (org.). Teoria crítica. Trad. Beatriz Katinsky e Regina Andrés Rebollo. Aparecida: Idéias \& Letras, 2008, p. 35), em trabalho sobre a Teoria Crítica alemã, escreve que: "A Teoria Crítica sempre foi especialmente fluida, até intencionalmente, e seria um erro tentar tratar até mesmo sua história inicial de forma unívoca." (p. 32). Ainda assim, ao penetrar na primeira fase da teoria crítica, o autor deixa registrado um horizonte de atuação que permite compreender o conteúdo das críticas lançadas, no sentido de que “(...) a Teoria Crítica é 'crítica' apenas na medida em que torna a desigualdade social aparente, aponta alguns candidatos plausíveis para as causas da desigualdade e permite $1^{\text {a }}$ sociedade em geral (ou, no mínimo, seu segmento oprimido) reagir de maneira apropriada."
} 
Ocorre que esta abordagem acabou por impulsionar um menosprezo teórico, refletido nas práticas penitenciárias, e favoreceu a emergência de posturas mais intransigentes alicerçadas em parâmetros positivistas nunca totalmente abandonados. No campo criminológico, tal abordagem tem erguido um muro tão impenetrável quanto as barreiras físicas do próprio cárcere, e o debate em torno de "alternativas" 169 possíveis ao cárcere tem se limitado, cada vez mais, por argumentos desanimados de que não há alternativa possível. E este quadro tem acarretado uma conclusão perigosa, como lembra RIVERA BEIRAS ${ }^{170}$ : "aquela que afirma que não existem alternativas - reais viáveis - ao emprego do sistema penal e/ou do cárcere para o tratamento e a regulação dos conflitos sociais. (...) Está aí precisamente o perigo: quando o debate e a reflexão crítica começam a abandonar (e isto é muito próprio em tempos de pensamento único), não é difícil imaginar o sombrio caminho que pode se iniciar."

Gerou-se um esgotamento acadêmico proporcional ao desinteresse social em relação ao cárcere. Claro que uma das vias de compreensão pode estar nas novas conjecturas sociais, mais egoísticas, ensimesmadas e via de conseqüência, menos politizada ${ }^{171}$. Especificamente em relação ao antes alardeado ideal ressocializador ocorreu uma circunstância interessante: muitas vozes negam sua eficácia, pugnando pela tese de que a ressocialização não passaria de uma estratégia mentirosa e, na melhor das intenções, utópica; ao mesmo tempo em que se ouve um sonoro "não" à ressocialização observa-se uma tentativa de reduzir tudo o que se dispõe a pensar de forma mais aberta (entendida aberta como mais humanizada) no cenário penitenciário como um desdobramento da tal ressocialização.

\footnotetext{
${ }^{169}$ Lembra Rivera Beiras (Lineamientos garantistas para uma transformación radical y reduccionista de La cárcel (uma visión desde España). Delito y sociedad. Revista de Ciencias Sociais. n. 14. v.9. 2000 p. 24, nota de rodapé n.1) que a discussão em torno das alternativas deve ser mais profunda do que como tradicionalmente é colocada no cenário público. Deve-se rumar para além das meras opções de penas alternativas ao cárcere que, na essência, não abrem mão do caráter privativo e que, ao lado do cárcere, ratificam a funcionalidade da punição penal e nada agregam à compreensão dos conflitos sociais de base. Por isso, o autor propõe que tal debate rume para a busca de alternativas a serem aplicadas em lugar do cárcere, e não junto (e com lógica semelhante) a ele.

${ }_{170}^{170}$ Idem. p. 23-24.

${ }^{171}$ Entendida aqui a política como a arena de discussões que perpassam o próprio indivíduo para atingir a pluralidade de semelhantes que, como ele ou não, carecem de uma diretriz estatal ou mesmo social, para melhor ajustarem seus horizontes de pluralidade.
} 
Em suma, tudo passa a ser reduzido ao horizonte da ressocialização, e a falta de estímulo em ir mais fundo, a pouca fé na mudança, tem favorecido ainda mais o solapamento do sistema e o seu isolamento total. Na medida em que boas propostas, advindas de tantas e tantas pessoas engajadas na melhoria da vida dos encarcerados (interessadas em promover políticas de redução dos danos decorrente do encarceramento) passa a ser tarimbada como um embuste, uma mentira, um fracasso, muito se deixa de agregar em prol da crítica ao sistema. Como pontuou ALVINO DE SÁ ${ }^{172}$, “continuar simplesmente dizendo que 'a pena de prisão está falida', que o ‘sistema penitenciário está falido', que ‘a ressocialização é um mito’ não traz proveito algum para o sistema penitenciário, e muito menos, para os presos que estão ali purgando suas penas."

Não há paradoxo algum nas ações que visam arrefecer o sofrimento atual, real e, paralelamente, pugnar por um sistema diverso de punição social. Estas ações, antes de meras atividades alienadas, são a mais clara concretização da mística da partilha enquanto fim em si mesma, e isto exige engajamento, exige o ato humano, mas não prescinde da reflexão crítica e nem se esquece de seu lugar no cosmo e seu papel no inter-jogo social. Numa das célebres frases deixadas por MADRE TERESA DE CALCUTÁ resta o seguinte ensinamento: "O que faço é uma gota no oceano; mas se eu não fizesse essa gota não existiria."

É fundamental que os temas afeitos ao cárcere, especialmente sobre os desdobramentos do encarceramento, voltem a ocupar as pautas públicas de forma consistente, sem falsas premissas que interrompem o ato de conhecimento antes mesmo que ele se apresente. É indispensável conhecer mais e melhor o funcionamento desta engenhosa invenção social chamada cárcere, até mesmo para que se tenha a exata noção de seus efeitos mediatos e imediatos para a vida de todos, em geral, e de cada um, em particular.

${ }^{172}$ Sá, Alvino Augusto de. Prisionização: um dilema para o cárcere e um desafio para a comunidade. In. Sá. A. A. Criminologia clínica e psicologia criminal. São Paulo: RT, 2007, p. 111. 
O tema que ora se apresenta é talvez o mais abruptamente rechaçado nos dias de hoje. As razões que levaram ao descrédito das premissas ressocializadoras igualmente desacreditaram tudo o que não fosse sinônimo de inocuização, de isolamento e ampliação da dor alheia. Este sadismo social, portanto, fez com que tudo o que se propusesse em sentido inverso passasse a ser considerado uma reinvenção do fracasso, uma proposta requentada e com os mesmos ingredientes de sempre. Estas análises apriorísticas e reducionistas foram, e continuam sendo, o calcanhar de Aquiles para a superação do cárcere, situação da qual os mais ácidos críticos parecem não ter se dado conta ${ }^{173}$.

Portanto, o que se desdobrará na sequência será um conjunto de propostas que, em primeiro plano, buscam apresentar diferenças essenciais entre as premissas do tratamento e da ressocialização e aquela denominada Reintegração Social. O uso desta expressão, inclusive, se dará sempre com iniciais maiúsculas, e por duas razões: a primeira visa diferenciá-la dos sinônimos correntemente atribuídos ao termo ressocialização, dentre eles reintegração social; a segunda tem por escopo a idéia de que o conteúdo que está na base do conceito é maiúsculo, é libertador, e por isso deve merecer uma face ortográfica que lhe imponha perante possíveis aproximações reduzidas.

De mais a mais, importa registrar de antemão que o princípio da Reintegração Social não representa um sinônimo de ressocialização e nem é dependente dele ou do cárcere para existir validamente. A sua independência lhe assegura a possibilidade de transversalizar os conceitos tradicionais, de afetá-los sensivelmente, sem que tenha sua essência abalada por isso. E tal ocorre porque o sentido que fornece vida à Reintegração Social não está no cárcere, mas sim fora dele; brota da sociedade, das relações humanas que não se apagam, da centelha de vida que singulariza os homens e os tornam seres de transcendência. A experiência da Reintegração Social, portanto, é edificante independentemente do cárcere, pois que sua práxis subsiste e é maior do que ele.

${ }^{173}$ Neste sentido, por todos Cf. Foucault, Michel. Vigiar e punir. O nascimento da prisão. Tradução Raquel Ramalhete. 32. Ed Petrópolis: Vozes, 1987. 
Conforme mencionado anteriormente, algumas vezes a aceitação da idéia de ressocialização está atrelada ao fato de que, ao menos, ela invoca uma execução penal mais humana, ou menos atroz, a ponto de evitar males desnecessários aos já inerentes à punição em si mesma considerada. Assim, nas palavras de H.J.KERNER ${ }^{174}$,

"um procedimento de execução que não ofereça socialização nem tratamento significa desumanização e retrocesso, porque na maioria dos casos o tratamento não deve ser entendido no sentido terapêutico estrito, senão simplesmente como atenção de caráter genérico, assistência social e prestações caritativas".

As redefinições atribuídas ao conceito de ressocialização, nas palavras de ALESSANDRO BARATTA $^{175}$, partiam basicamente de duas alternativas: a primeira se relacionava com a oferta de uma série de direitos ao condenado, e a segunda com a necessidade de que o Estado assegurasse o cumprimento da primeira. De toda forma, tanto uma como outra não deixavam de expressar a ideologia tradicional da ressocialização, na qual o seu significado legítimo sempre esteve vinculado à execução penal, e com isso as ações que concretamente se realizavam sob este prisma ostentavam a capacidade de submeter o indivíduo ao sistema penal. Portanto, as propostas de índole ressocializadora, em maior ou menor escala conforme as perspectivas adotadas tinham na submissão um ponto de convergência.

O fundamento da ressocialização está associado a uma prática de empoderamento de um pelo outro, onde um subtrai o outro de si para devolver-lhe, na sequência, à imagem e semelhança de quem ostenta tal poder. "Por esta imposição total, o recluso deixa de ser um ente humano

${ }_{175}^{174}$ Apud. Gárcia-Pablos. Op. cit, p. 663.

175 Baratta, A. Reintegrazione Sociale. Ridefinizione Del concetto ed elementi di operazionalizzazione. Dei Delitti e Delle Pene: Rivista de Studi Sociali, Storici e Giuridici Sulla Questione Criminale. n. 3, 1994/1996, p.140. 
livre para se converter numa 'coisa', depositária de 'prescrições', que é o elemento básico de medicação entre 'opressor' e 'oprimido'”. ${ }^{176}$

Nesta perspectiva, uma das grandes contradições do cárcere repousaria no fato de que, por meio dele, se preconiza a introjeção de normas sociais que sequer a parcela "livre" da sociedade assume como diretriz entre os "seus", e que denominaremos de doutrina do triplo " $r$ ": regramento, respeito e responsabilidade. Este quadro é retratado por KALINSKY \& VALERO ${ }^{177}$ como "uma condensação extrema de sentidos permitidos e uma exclusão profunda de sentidos proibidos". Trata-se, portanto, de uma contradição insuperável na tentativa de atribuir um conteúdo moralizante à execução penal que sequer é efetivamente cumprido pela parcela social mais combativa a favor do cárcere. O sistema é, assim, um signo fiel de nossa época marcada pela simultaneidade de situações avessas e contraditórias entre si.

Nas palavras de CAFFARENA ${ }^{178}$, "ressocialização é aquele processo pelo qual se modificam ou neutralizam os fatores exógenos e endógenos que impulsionaram o indivíduo a delinquir". Com isto, importa dizer que uma vida exemplar no cárcere não tem nenhuma relação com a saúde mental, com a autonomia individual ou com um suposto reconhecimento de culpa por parte do indivíduo, mas apenas expressa um sentido de adequação às normas disciplinares, que não possuem predicado algum para orientar o retorno do encarcerado à liberdade, para reorganizar sua vida ou colaborar para que ele seja suficientemente forte para superar o estigma do criminoso e do ex-presidiário que terá de suportar $^{179}$.

O ideal ressocializador é, portanto, construído sobre uma inquebrantável base disciplinar e a única resposta que espera dos presos é o silêncio ensurdecedor da submissão, sendo o maior

\footnotetext{
${ }^{176}$ Miralles, T. O controle formal: La cárcel. In: Bergalli, Roberto; Ramirez, Juan Bustos; et ali. El pensamiento criminológico. Vol II. Bogotá: Editorial Temis, 1983, p. 106.

${ }_{177}$ Kalinsky, Beatriz; Valero, Miguel. Democratizar la cárcel: una contradicción de términos? Capítulo Criminológico: Revista de las Disciplinas del Control Social. n. 2, v. 25, 1997, p. 125.

${ }^{178}$ Caffarena, Borja Mapelli. Desviación y resocialización. Cuadernos de Política Criminal. n.23, 1984, p. 312.

${ }^{179}$ Rauter, Cristina. Op. cit, p. 106.
} 
ou menor grau de obediência à hierarquia o fator determinante para divisar o comportamento normal e o anormal havido no cárcere e, portanto, para determinar a duração das penas dos encarcerados. Quanto mais dócil, submisso, obediente e objetificado, melhores a chances de ser reconhecido como "perfeitamente ressocializado" à vida em sociedade - expressão contraditória por excelência.

Além das contradições internas ao ideal ressocializador, R. BERGALLI ${ }^{180}$ ainda destaca uma insuficiência externa, ligada à eficácia da proposta. Considerava o professor catalão que se a experiência vivida no cárcere fosse breve, não se poderia falar em ressocialização completa. $\mathrm{Na}$ melhor das hipóteses haveria uma interferência no processo de socialização secundária, isto é, uma contingência a mais para ser agregada às muitas outras que a pessoa já havia experimentado em sua história de vida. A ressocialização, paradoxalmente - e esta seria a razão de seu fracasso -, imporia uma impossível renúncia ao passado, e não apenas enquanto tempo transcorrido, mas como conjunto de experiências que formam o "eu" da pessoa. E o período de privação de liberdade, se não fosse capaz de desconectar por completo a pessoa de sua história, seria incapaz de se transformar numa realidade única em sua vida, e quando muito representaria uma intensa e traumática realidade dentre as várias que já foram e as muitas que ainda estariam por vir.

O cárcere, sob esta perspectiva, promove uma experiência de socialização complementar, na medida em que impõe um conjunto de eventos que hão de juntar-se a outros, historicamente vivenciados, para conformar o sujeito. E quanto mais trágica for a experiência, mais melancólica será a significação dela extraída, e mais vulnerável será a estrutura psicológica da pessoa que a suportou. O cárcere, por si, não é capaz de capturar a vida dos presos, de transformá-los; o que faz é torná-los fragilizados, e isso nem de longe representa que tenham eles adotado todos os "valores da sociedade". Pode sim promover-lhes transtornos, traumas

${ }^{180}$ Bergalli, Roberto. Crítica a La criminologia. Hacia uma teoria crítica Del control social em América Latina. Bogotá: Editorial Temis, 1982, p. 207. 
intensos, mas em geral não são eles suficientes para impor, sozinhos, uma transformação de base.

O maior dos problemas, portanto, não está propriamente no cárcere e nos seus mórbidos processos de prisionização ${ }^{181}$, mas se encontra além deles. O homem é capaz de superar os horrores do encarceramento, ainda que em frangalhos, mas sua condição combalida necessita de um suporte para que a sua história não se perca no horizonte atroz que passará a caminhar com ele. E sem esta compreensão, sem este auxílio, o homem sucumbirá. E isso se dará muito menos em razão da realidade objetiva, e muito mais pela fragilidade interior que o isolamento social impõe. Noutras palavras, a primeira ruína se dá não no homem social, mas no sujeito consigo-mesmo, na base existencialmente humana, que se perde em meio às aparências que lhes são forjadas para depois vir a perder-se dos demais. É certo que "a experiência vivida somente deixa nos encarcerados um somatório de ódio e ressentimento sórdido que acarretará maiores violências." 182

Uma alternativa que se valha de um conceito de ressocialização que respeite a autonomia ética do recluso, tal como preconizam os adeptos da tese da ressocialização mínima não deixa de representar uma versão bem elaborada, de reconhecido valor, mas que não consegue fugir da base que é comum a todas as propostas desta natureza. E esta base se assenta, em se tratando da mais evoluída (humanizada) acepção de ressocialização, na idéia de tolerância. Tal horizonte, portanto, impõe o seu limite intransponível de atuação como a mais humanizada intervenção possível por meio do cárcere.

\footnotetext{
${ }^{181}$ Não iremos ingressar neste tema, cuja existência já foi repisadamente atestada por importantes pesquisas empíricas. Neste sentido, se destacam a obra de Erving Goffman (Manicomios, prisões e conventos. Trad. Dante Moreira Leite. 4 ed. São Paulo: Perspectiva, 1992) e Donald Clemmer (The prison comommunity. New York: Holt, Rinehart and Wilson, 1958). No Brasil, um trabalho muito pertinente ao tema trabalhado foi escrito por Alvino Augusto de Sá (Prisionização: um dilema para o cárcere e um desafio para a comunidade. In. Sá. A. A. Criminologia clínica e psicologia criminal. São Paulo: RT, 2007).

${ }^{182}$ Neuman, Elías. Prisón, La inhumanidad de lo humano. Pensamento Penal Del Sur. v. II, 2006, p. 65.
} 
A tolerância é uma daquelas expressões que, tal como a própria ressocialização, abarca uma série de significados e não raro é utilizada em contextos dos mais variados. Por isso, importa realizar um comparativo em torno dos dois sentidos mais conhecidos da palavra tolerância, para que assim seja possível associá-la, de forma mais ou menos singular, às práticas ressocializadoras de hoje e de outrora. De acordo com o Dicionário Houaiss da Língua Portuguesa (Versão Eletrônica, 2001), um sentido possível para tolerância é o de "indulgência, condescendência".

A idéia de indulgência não está apenas na base dos ideais ressocializadores tradicionais, mas representa, antes disso, uma herança transmitida pela doutrina religiosa e pelo direito canônico. Na apresentação de sua obra sobre Direito Penal Canônico, o PADRE JoÃo CARLOS ORSI $^{183}$ deixa consignado o papel indulgencial da punição, ainda hoje preconizado pelo direito penal canônico, justificando assim a aplicação da pena pela possibilidade de, por meio dela, o infrator recuperar-se de si mesmo.

"A pena imposta pela autoridade eclesiástica deve ser considerada um instrumento de comunhão, pois a pena na visão do direito eclesial visa recuperar o infrator daquelas deficiências do bem individual e do bem comum que surgiram por causa do comportamento antieclesial, delituoso e escandaloso do infrator." 184

O mecanismo da punição, enquanto tributário dos preceitos religiosos, haveria de ser concebido como uma via de comunhão, e não propriamente de expiação. A idéia de prevenção especial positiva (ressocialização, portanto), tal como apreendida pelas teorias da pena laboradas no campo jurídico, teve influência decisiva do conceito de poena medicinalis,

183 Orsi, João Paulo. .Direito penal canônico. São Paulo: Ltr, 2009, p.13.

184 Idem. Ibidem, p. 13. 
fruto de uma construção filosófica espiritualista do homem, informada pela idéia de livrearbítrio em sua forma mais original.

Este projeto pedagógico atribuído à pena, e cuja criação remonta à época medieval, foi de todo construído pela doutrina penal canônica e informado pelo prisma do reconhecimento da punição como mecanismo de purificação e, ao mesmo tempo, como demonstração do perdão cristão. O perdão representava, assim, um instrumento para o caminho da purificação da alma errante. Com isso, a idéia de pena como "medicina da alma", entendida como um bem para quem a suporta, nunca perdeu seu vigor apesar de ter deixado, no discurso científico de caráter laico, de se justificar plenamente com base nos fundamentos religiosos.

Os que mais perto chegaram do discurso religioso foram os positivistas da Escola Correcionalistas, dentre os quais se destacou o espanhol DORADO MONTERO ${ }^{185}$. De formação católica, ainda que tenha sido posteriormente excomungado pelo Bispo de Salamanca em razão de suas idéias, D. MONTERO inspirou decisivamente uma época de autores, sobretudo na Espanha, ao defender que o delinquente era merecedor de indulgência dada a sua incapacidade de determinar-se socialmente. A tônica, portanto, não fugiu do cerne da liberdade de ação, e, mesmo que tendo negado o livre-arbítrio ${ }^{186}$ no criminoso (como, ademais, fizeram sem muitas divergências os partidários do positivismo criminológico), D. MONTERO não se eximiu de pugnar o caráter indulgente da pena como mecanismo de ofertar o aperfeiçoamento do infrator para a sociedade.

185 Cf. Zaffaroni \& Pierangeli. Op. cit. p. 305-306. Os autores, inclusive, consideravam Dorado Montero como "o mais coerente dos positivistas".

${ }^{186}$ Neste sentido, arremata o Professor Tércio Sampaio Ferraz Junior (Estudos de filosofia do direito. $2^{\mathrm{a}}$ edição. São Paulo: Atlas, 2003. p. 87): "O advento do Cristianismo irá trazer importantes reflexões para o tema da liberdade. No contexto da Patrística até a alta Idade Média, a questão tomará um rumo original, decisivo para a elaboração jurídica da liberdade. Crescerá em importância a noção de liberdade interna, como núcleo central de uma antropologia filosófica, ganhando certa autonomia em relação à liberdade limitadamente como conceito político." 
Dada a importância religiosa para a compreensão do sentido imanente de ressocialização (e também de tratamento penitenciário), quadra abrir um pouco mais a investigação acerca dos elementos de índole religiosa que se fizeram presentes na essência e na origem do conceito ora questionado. Trazida inicialmente pelos escritos bíblicos de São Paulo $(\operatorname{Rm~} 7,18)^{187}$, a distinção entre querer e poder marcou a fronteira a partir da qual se erigia uma nova compreensão da liberdade, até então desconhecida pela filosofia grega, onde querer (velle) sem poder (posse) não fazia nenhum sentido ${ }^{188}$. Nas palavras de ÉtIENNE GILSON ${ }^{189}$ :

"A Epístola aos romanos havia distinguido claramente o querer de sua eficiência, porque um independe do outro (...). Esta discussão adquire em santo Agostinho a forma mais precisa de velle e do posse. A partir desse momento, nenhuma ambigüidade é possível, porque, falando em absoluto, querer não é poder e vice-versa”.

A partir deste momento, passou a ser possível querer algo não possível e, ainda, poder algo não querido. Caberia à vontade, e somente a ela, a opção positiva ou negativa de realizar o ato. Nesta perspectiva, a vontade seria dona de si, podendo querer ou não querer algo, nada estando mais à disposição da vontade do que ela própria. A teologia católica exerceu relevante papel na edificação das bases do que seria denominado de livre arbítrio. Foram de SANTO Agostinho, conforme já pontuado por ÉtIENNE GILSON, os ensinamentos preliminares que conferiram, de maneira definitiva, os pilares para a estruturação da liberdade entendida como livre decisão ou escolha interior.

\footnotetext{
${ }^{187}$ Carta de São Paulo (Epístola) aos Romanos, VII. 18: "Eu sei, efetivamente, que em mim, isto é, na minha carne, não habita o bem: querer o bem está, sim, ao meu alcance, mas realizá-lo não."

${ }^{188} \mathrm{Na}$ filosofia grega, "a vontade ou apetite movia o homem para aquilo que estava a seu alcance e lhe era próprio, isto é, adequado a sua natureza.”. Ferraz Junior, Tercio Sampaio. Op. Cit. p. 87.

189 Gilson, Étienne. Gilson, Étienne. O espírito da filosofia medieval. Trad: Eduardo Brandão. São Paulo: Martins Fontes. 2006. p. 385-386.
} 
Etimologicamente, o termo livre arbítrio se origina do latim liberum arbitrium. Ora interpretado como livre escolha, livre decisão, livre vontade ou mesmo como decisão autoritária e consciente ${ }^{190}$, o importante está na consideração de sua essência: trata-se de uma vontade ou de um querer incoercível, não alicerçado nas necessidades e apetites, mas que conta exclusivamente com as luzes da razão. Ao ser questionado por EVóDIO sobre as origens do mal e a conseqüente ocorrência no pecado, S. AgOstinHo chega a fazer sinceras reflexões acerca de seu passado, revelando ter sido esta uma indagação sempre presente em sua vida ${ }^{191}$. O certo é que a partir de sua conversão ao catolicismo, ele não mais conceberia a vontade senão como a fonte de todos os pecados, inexistindo qualquer nascedouro secreto do mal a exonerar a imposição de uma justa responsabilidade ${ }^{192}$.

Dessa forma, a vontade que emerge do livre arbítrio sempre poderá escolher entre ser boa ${ }^{193}$, ao que se aproximará da sabedoria e promoverá a vivência das virtudes (hábito do bem enquanto finalidade da vida), ou ser má, cedendo às paixões e desejos, o que acarretará uma angústia eterna ${ }^{194}$. Esta vontade seria transparente, ausente de constrangimentos ou determinações limitadoras. São Tomás de Aquino também cuidou de esclarecer que o livre arbítrio não era potencia apetitiva, senão que potencia cognitiva. Noutras palavras, quis dizer

\footnotetext{
${ }^{190}$ Agostinho, Santo. O livre-arbítrio. Trad: Nair de Assis Oliveira. $5^{\text {a }}$ edição. São Paulo: Paulus, 2008. p. 247.

${ }^{191}$ Em O livre-arbítrio (2008, p. 28) extrai-se a resposta de Santo Agostinho acerca da indagação de Evódio dos porquês praticarmos o mal: "Ah, suscitas precisamente uma questão que me atormentou por demais, desde quando era ainda muito jovem. Após ter-me cansado inutilmente de resolvê-la, levou a precipitar-me na heresia (dos maniqueus), com tal violência que fiquei prostrado. Tão ferido sob o peso de tamanhas e tão inconsistentes fábulas, que se não fosse meu ardente desejo de encontrar a verdade, e se não tivesse o auxílio divino, não teria podido emergir de lá nem aspirar à primeira das liberdades - a de buscar a verdade."

${ }^{192}$ Afirma Agostinho (O livre-arbítrio. p. 26): "As más ações são punidas pela justiça de Deus. Ora, elas não seriam punidas com justiça se não tivessem sido praticadas de modo voluntário."

${ }^{193}$ A boa vontade "é aquela pela qual desejamos viver com retidão e honestidade, para atingir o cume da sabedoria. Tal sabedoria é o reino da lei eterna em nós. A vontade humana é boa porque pode participar da sabedoria de Deus". E arremata: "Depende de nossa vontade gozarmos ou sermos privados de tão grande e verdadeiro bem. Com efeito, haveria alguma coisa que dependa mais de nossa vontade do que nossa vontade?" (Op. Cit. p. 56-57).

${ }^{194}$ O preço pela livre escolha das paixões, segundo Agostinho porta em si muitos males: "Ir do temor ao desejo; da ansiedade mortal à vã e falsa alegria; dos tormentos por ter perdido um objeto que amava ao ardor de adquirir outro de que ainda não possui; das irritações de uma injúria recebida ao insaciável desejo de vingança. E de todo lado que se volta, a avareza cerca este homem, a luxúria o consome, a ambição o escraviza, o orgulho o incha, a inveja o tortura, a ociosidade o aniquila, a obstinação o excita, a humilhação o abate. Enfim, poderemos considerar como pouca coisa essas penas que necessariamente suportam todos aqueles que não aderem à verdadeira sabedoria, assim como bem o percebes." (Op. Cit. p. 53).
} 
que o querer nada tinha de apetitus, de necessidade, mas representava sim uma virtude cognitiva, um ato livre e desimpedido de discernimento ${ }^{195}$.

Assim como Agostinho, o tomismo bebe da fonte aristotélica quando considera que "a própria noção de escolha voluntária implica na noção de razão" ${ }^{196}$. Destarte, mesmo a razão em seu mais elevado gradiente não seria suficiente para salvar o homem da concupiscência, da aproximação e contágio com os desejos e paixões. À sabedoria, único expediente apto a libertar os homens, deveria se unir um elemento indispensável de índole metafísica: a graça.

A graça ${ }^{197}$, nesta esteira, representaria um dom divino capaz de tornar a vontade boa. Não se trataria de uma supressão da vontade, pois à ausência da graça não acarretaria a ausência da vontade, mas fomentaria um livre arbítrio impossibilitado de querer o bem ou, querendo-o, não seria capaz de realizá-lo. Esse poder de bem usar o livre arbítrio é precisamente a liberdade.

Noutras palavras: o mal é inseparável do livre arbítrio, exatamente por se tratar de opção diversa à finalidade natural do ser, que é a felicidade. Ocorre que a felicidade somente pode ser alcançada com a prática do bem, e a marca da liberdade está no poder de evitar o mal e realizar o bem. Neste sentido, aquele que se encontrar confirmado na graça, a ponto de não poder fazer o mal, encontrar-se-ia no supremo estágio da liberdade.

A liberdade enquanto livre arbítrio, cujo núcleo estava concentrado numa liberdade ideal da vontade, e cuja graça divina como elemento metafísico servia de complemento coerente à

${ }^{195}$ Aquino, São Tomás. Suma Teológica. I Parte. Trad: Alexandre Correa. $2^{\text {a }}$ edição. Caxias do Sul: Sulina Editora, 1980. p. 735.

${ }^{196}$ Gilson, Étienne. Op. Cit. p. 369.

${ }^{197} \mathrm{O}$ estudo da graça adquire maiores discussões no campo da teologia, especialmente quando consideradas as doutrinas católicas de um lado, e as doutrinas protestantes do outro. Para os protestantes, sobretudo aqueles calvinistas, a graça não somente agrega a vontade racional em busca da verdadeira liberdade, como ela mesma atinge a vontade do homem, eis que a salvação somente é possível predestinados pela graça divina. 
filosofia teológico-cristã, negligenciava propositalmente as contingências sensíveis às quais cada um dos homens se sujeita e, neste sentido, tornava a liberdade uma panacéia vazia e frágil às críticas que tão logo a atacaram.

Alheia ao real plano imanente na sua origem, a doutrina da ressocialização permaneceu tributária desta visão abstrata de que o criminoso era um ser alheio aos "apetites" da vida. Por outro lado, como restou consignado no capítulo anterior, foi a doutrina positivista a primeira a discursar no plano criminológico sobre a pena medicinal, já não mais como cura da alma apenas, mas sobretudo do corpo laicizado.

Considerando o cenário histórico-filosófico do iluminismo e a sua oposição às matrizes religiosas, era compreensível que o transporte da pena canônica fosse "camuflada" em torno de argumentos diversos. E esta flexibilidade, esta dualidade, ajuda a explicar a variabilidade de propósitos que a ressocialização se prestou e ainda hoje se presta a "solucionar". Seja com fundamento na purificação do delinquente, na expiação de sua culpa ou na oportunização de encontro consigo-mesmo, a pena ressocializadora também encontra razões na adequação à ordem, na aprendizagem dos valores, na adaptação das condutas e no adestramento para a sociedade.

Neste jaez, o fim ressocializador da pena se consubstancia, concomitantemente, na reeducação (plano exterior) e na recuperação moral (plano interior) do criminoso, pressupondo, então, um sujeito imoral que deveria se redimir de sua conduta. Os próceres da idéia de ressocialização no cenário criminal, e dentre eles quadra citar FRANZ VON LISZT ${ }^{198}$, apenas tentaram retirar a religiosidade do tema ao impor o termo "correção moral" no lugar da idéia de "correção espiritual" largamente adotada pela doutrina canônica. Mas ainda que os

\footnotetext{
${ }^{198}$ Lembra Iñaki Rivera Beiras (Op. cit, p.13) que o conhecido Programa de Marburgo estabeleceu três possíveis efeitos da prevenção penal: a correção do infrator necessitado de tal reforma, bem como a intimidação e a inocuização dos que prescindissem dela. C.R. Bitencourt (Op. cit, p.93) recorda que, na concepção proposta por Liszt, à pena deveria projetar uma tríade composta pelos ideais de intimidação-correção-inocuização.
} 
positivistas tradicionais tenham buscado laicizar o tema, o que permitiu sua reprodução sem os "inconvenientes" que a religiosidade impõe a uma sociedade juridicamente secular, nunca deixaram de se referir a ele com os tons pietista e indulgente que lhe deram a base.

Esta primeira apreensão do sentido de tolerância forneceu as diretrizes para que se erigisse o que restou conhecido como programa ressocializador máximo, que tudo justifica sob o embuste de estar ofertando uma óstia em forma de punição.

O outro sentido da palavra tolerância, não menos utilizado, é o de "tendência a admitir, nos outros, maneiras de pensar, de agir e de sentir diferentes ou mesmo diametralmente opostas às nossas". Numa primeira aproximação o sentido apresentado fornece a impressão de que os problemas sociais estariam bem solucionados, isto é, seriam harmonizados se todos assumissem uma postura tolerante perante os outros, e também perante a si mesmo.

Este sentido tem sido o mais utilizado nos discursos ressocializadores contemporâneos, que em razão das sutilezas de seu conteúdo passaram a se denominar de programas de conteúdo mínimo, querendo transparecer que diferentemente das propostas anteriores - inseridas numa denominação de conteúdo máximo e calcadas na tolerância enquanto indulgência -, esta última acepção compreenderia a pena como uma oportunidade de promover o infrator, respeitando as suas orientações pessoais e zelando por sua dignidade humana.

Importante notar que se trata de um discurso sedutor, que não raro se vale de bases constitucionais modernas, como o princípio da dignidade da pessoa humana e do Estado Democrático de Direito, para justificar suas práticas consideradas igualmente democráticas. Há, indubitavelmente, uma mudança de enfoque, fruto do novo sentido emprestado ao termo tolerância. 
Mas para desmascarar o fascínio que o termo tolerância pode expressar, propomos um exercício: mudar o nome de todas as Secretarias de Estado, Coordenadorias e Gabinetes Administrativos, Chefias e Departamentos Penitenciários que levam as rubricas "ressocialização" ou "tratamento" no nome para o termo "tolerância penitenciária".

Assim, se teria não mais Coordenadoria de Ressocialização/Tratamento, mas Coordenadoria de Tolerância Penitenciária; em vez de Departamento de Ressocialização/Tratamento, se falaria em Departamento de Tolerância Penitenciária e, por fim, as Chefias e Gabinetes de Ressocialização dariam lugar as Chefias e Gabinetes de Tolerância Penitenciária. Será que esta proposta seria do agrado da classe política e da sociedade? Dificilmente.

E isso pelo fato de que o termo ressocialização, como explorado no capítulo anterior, é tranquilizador, passa despercebido pelos menos interessados dada a quietude que tende a promover, e assim admite tudo que se preste a legitimar o arbítrio público. A utilização oficial do termo ressocialização também possui outros benefícios: o de fazer com que a sociedade não compreenda exatamente o que se quer com ele, e assim, permanecendo alheia ao campo da execução penal, acaba favorecendo que uma gestão penitenciária mal intencionada atue de forma livre, por vezes arbitrária, eis que o controle social sobre ela será praticamente nulo.

Portanto, se a palavra tolerância traz consigo uma certa angústia ao remeter a uma idéia de conflito apenas provisoriamente apaziguado, o mesmo deve ser estendido ao conceito de ressocialização, que deve passar a ser lido com inquietude e não tranquilidade. As propostas alicerçadas sobre este paradigma da tolerância são, sempre, de índole unilateral. Pode haver um respeito à diferença, uma consideração (que não significa interesse), uma curiosidade turística para com a história de vida do infrator, e até mesmo um cuidado em não forjar nele uma ordem de valores que lhes são estranhos. Ocorre que tudo é feito à distância, sem envolvimento subjetivo (o que não é o mesmo de engajamento profissional). É dizer: a 
ressocialização, em seu modelo mais elaborado, se reveste de um conjunto de práticas que não violam a vontade alheia e... só.

Se, por um lado, não há interesse de forjar uma motivação, por outro, e isto é claro, também não se confere importância quase alguma às razões do infrator e a suas motivações eminentemente humanas. Promove-se, assim, um despojamento ex negativo, pelo desprezo e pela carente importância que se dá ao outro. Neste sentido, o filósofo e educador MARIO SÉRGIO CORTELLA ${ }^{199}$ num texto dialogado com o psicólogo YVES DE LA TAILlE, expressa sua "rebeldia" para com a palavra tolerância, na medida em que ela produziria um "sequestro semântico, pois quando alguém a usa, está querendo dizer que suporta o outro. Afinal, tolerar é suportar."

E exatamente aqui se divisa mais um limite aos programas de ressocialização: eles não passam de uma variação de propostas alicerçadas numa idéia de que a sociedade, por uma questão de humanidade (mais uma vez a raiz religiosa encontra-se patente), deve suportar, aceitar com resignação o criminoso em seu meio. E prossegue CORTELLA ${ }^{200}$ dizendo que tolerar guarda um sentido frágil e as práticas que se sustentam da tolerância restam igualmente fragilizadas, pois o que tolera diz: "Você não é como eu, aceito isso, mas continuo sendo eu mesmo. Não quero ter contato, só respeito a sua individualidade".

Talvez por isso tantos sejam os presos que interpelam os técnicos e voluntários com a seguinte pergunta: "Se você me encontrasse na rua, continuaria a conversar comigo, me olharia nos olhos, ou viraria e atravessaria a rua, provavelmente com medo?”. Uma abordagem como esta é extremamente rica, pois denuncia uma preocupação ética relacionada ao sentimento de pertença ou de exclusão de um determinado grupo.

${ }^{199}$ Cortella, Mario Sergio; De La Taille, Yves. Nos labirintos da moral. Campinas: Papirus, 2005, p. 28.

${ }^{200}$ Idem. Ibidem, p. 29. 
Como ressaltou YVES DE LA TAILLE ${ }^{201}$, "se tenho vergonha perante você é porque o considero como um 'nós', eu e você formamos um 'nós'. Se eu não sentir vergonha, mas medo, é porque você representa um 'eles' para mim." O que o preso indaga é exatamente isso, se o medo é o sentimento que, apesar do discurso, esta na base da relação. Noutras palavras, quer saber por meio de uma abordagem discreta, porém penetrante, se ele é um (alguém) ou nenhum (ninguém) para o indagado. E tal questionamento é justificado pela abordagem que é realizada no cárcere, mediada pela tolerância, pelo respeito distanciado e que renuncia a vocação humana de um contato que ultrapasse os limites do cárcere, e assim poderia subjetificar os interlocutores.

Assim, tudo continua como sempre, mesmo fora do ambiente prisional: o técnico continua sendo técnico, o voluntário continua sendo cidadão, e o preso continua sendo preso. A tolerância, portanto, por mais bem intencionada que seja, por mais elaborada que se apresente, não é capaz, sequer, de fazer cessar o ciclo de vulnerabilidade promovido e ampliado no cárcere.

Miguel PEREZ \& Victoriano RAMOS ${ }^{202}$ apresentam uma distinção entre as expressões tolerância e compreensão em sentido semelhante ao que vem sendo abordado. Assim, para os autores, a tolerância, da mesma raiz latina do termo conduzir, impõe uma idéia de que o outro deve ser conduzido consigo/dentro, de alguma maneira.

Portanto, o sentido apresentado da palavra tolerância remete a uma aproximação na qual um sujeito é levado a aceitar as premissas do outro. Neste aspecto, tolerar a presença do preso na sociedade é ser levado a aceitá-lo tal como ele é: ex-preso, em geral pobre, vulnerabilizado e estigmatizado.

\footnotetext{
${ }^{201}$ Idem. Ibidem, p. 30.

${ }^{202}$ Perez, Miguel Fernandez; Ramos, Victoriano Gracia-Redondo. Tolerancia y antropologia pedagogica de la comprension: utopia, carcel real y legislacion de la hipocresia social. Eguzkilore. Cuaderno del Instituto Vasco de Criminologia. n.8 (extraordinario). San Sebastián, 1995, p. 185-186.
} 
É olhar para o outro com olhos solitários, com um olhar ocioso quem não se esforça para encontrar esse outro que não está perdido no universo, mas entre os dois, e com isso resta, por melhor intencionada que possa ser, a perspectiva egoísta do avaliador, incapaz de se sintonizar com a magia da perspectiva de quem é avaliado.

Compreender, da raiz latina prender-con, teria o sentido de tomar algo em companhia do outro, apreender da realidade algo tal como percebido pelo outro, pelo distinto, que deixa de ser distinto na medida em que há o transporte para o seu universo e ele então passa a ser conhecido. Este sentido importa uma tarefa, um percurso a ser assumido: o de sair de si para se aportar no outro, na sua história e na sua forma de entendimento do mundo, tal como este mundo é absorvido ${ }^{203}$.

A compreensão assume o projeto de que cada um é detentor de uma parcela singular do mundo, e somente o interesse por conhecer o mundo outramente pode minimizar a barbárie do ensimesmamento e construir verdadeiras pontes que permitam a experiência da realidade tal como vivida pelo outro e, consequentemente, a ampliação dos horizontes próprios do saber na progressiva construção da plenitude humana - forma mais idônea para aproximar o homem da transcendência.

BLAISE PASCAL ${ }^{204}$, em seus escritos filosóficos, deixou consignado que a compreensão do mundo não pode ser adquirida por meio de um "espírito de geometria" (l'esprit de geométrie), matemático, formalista e alheio da realidade, mas que deveria se valer de um "espírito de finura" (l'esprit de finesse), ou seja, sutil e doce, verdadeiramente preocupado em conhecer a si e ao outro de forma estreita. Há de se extrair, desse modo, que a tolerância é senão a rota

\footnotetext{
${ }^{203}$ Apesar da distinção semântica, os autores por diversas vezes se valem das expressões como sinônimas, Cf. Perez \& Ramos, p. 188.

${ }^{204}$ Apud. Perez \& Ramos p. 187.
} 
mais conhecida até a compreensão, mas não é a única. A experiência da tolerância, considerada uma das mais importantes conquistas dos direitos humanos, não esgota todas as possibilidades interativas entre os homens.

Ela foi um passo importante na direção da comunhão, que exige respeito, mas não se esgota neles; além do respeito, da certeza da validade que cada um assume na existência, a comunhão promove uma fusão entre as partes que, em última instância, religa os homens na unidade da criação: "No princípio era o Verbo (...). [O Verbo] era a verdadeira luz que, vindo ao mundo, ilumina todo homem."205

Enfim, oferecidas as atividades a ressocialização do encarcerado está magicamente cumprida! Ora, não é esse o discurso das Autoridades Penitenciárias quando divulgam, como que tirando um fardo de suas costas, o número de presos inseridos em tais atividades, logo dizendo que estão sendo ou foram ressocializados? Fazem também divulgar o número de famílias de presos atendidas pelos setores sociais, ou o número de internos cujos processos foram assumidos pelos poderes competentes.

E tudo isso se presta a engrossar a idéia de ressocialização como tolerância, como um somatório de ações que não fazem outra coisa se não oferecer um pouco mais de sentido a esta tarefa árdua de suportar/tolerar aqueles que são enviados diariamente ao cárcere.

Se a pena representa, de um lado, uma artimanha psicológica para que o ego dos "ordeiros" se purifique a partir do sofrimento dos infratores, e de outro, uma transferência dos impulsos negativos para estes mesmos sujeitos, fazendo deles um concentrado de impurezas, a ressocialização será mais facilmente promovida quando a equipe prisional não tiver de se envolver com os problemas que também transferiu ao infrator, e assim tudo continua como

\footnotetext{
${ }^{205}$ Evangelho de São João: 1; 1-10.
} 
dantes ainda que com ares de mudança. O principal a considerar, empiricamente falando, é que nenhum programa institucionalizado no cárcere será capaz de "resolver" o problema da criminalidade, pelo simples fato de que tal fenômeno é complexo, multifatorial e, por certo, tem no cárcere o pior local para tal empreitada.

Com isso, não se quer jogar por terra os esforços de tantos técnicos em oferecer programas laborativos, educacionais, culturais ou religiosos no cárcere, mas apenas retirar destas propostas o caráter resolutivo que muitas vezes as levam à frustração. Como destaca CAFFARENA ${ }^{206}$, "é evidente que a ideologia do tratamento conduz necessariamente à idéia de que algum dia a sociedade poderá acabar com a deliquencia”.

A humanidade que as orienta, como já abordado, deve ser encarada com um olhar realista: o que se quer é oferecer ocupação e entretenimento sadios aos presos, minimizando, quando for de livre opção dos destinatários, os danos que o ócio e o contágio com o cárcere produzem. Se desta ação vierem a surtir outros desdobramentos, como a possível aquisição de um ofício pelo interno ou mesmo a aceitação de uma denominação religiosa no cárcere, tais eventos não devem fazer parte dos objetivos da ressocialização, mas devem ser lidos como ocorrências possíveis e não necessárias.

Diante disso, há de se considerar que a própria negativa em integrar os programas de ressocialização enquanto tolerância deve ser compreendida como uma decorrência da vontade livre do sujeito, do desejo de se expressar diversamente, e nisto também resulta o caráter tolerante que deve orientar as práticas ressocializadoras contemporâneas.

Este ponto de vista impõe, tanto aos administradores penitenciários quanto para os magistrados, a impossibilidade de agravar a situação legal do recluso com base na carência de

${ }^{206}$ Caffarena. Op. cit, p. 387. 
participação de programas ressocializadores, pois que deve tal postura ser entendida como uma manifestação do direito a ser diferente, tal qual aceito e pugnado numa nação de índole pluralista.

A ressocialização também não deve ser encarada como parâmetro para se aferir o prognóstico criminal do detento, e nisso laboram várias teses, sobretudo de caráter jurídico, que vislumbram na recidiva um sinal de fracasso da ressocialização ${ }^{207}$. Isso é um grave equívoco, se tomada a tolerância como base para as propostas de intervenção carcerárias.

Os programas de ressocialização pautados pela tolerância devem respeitar a diferença, inclusive se ela representa a continuidade em modos de vida alheios ao do proponente, no caso o Estado, e neste contexto se inclui a possibilidade de agir de maneira conforme ou desconforme às normas penais.

Deve-se fugir das pretensões mais simplistas de transferir para os programas de ressocialização o papel de solucionar questões que são de responsabilidade de todos, e não apenas dos técnicos e dos projetos por eles propostos. E tal tomada de posição ou de consciência já representa um avanço, ao mesmo tempo em que uma desoneração àqueles que estão em contato com a realidade nua e crua dos cárceres. Não há muito mais o que fazer materialmente no cárcere do que prestar atividades que podem agregar à vida e ao espírito dos presos, na medida de suas vocações e disponibilidades. E isso, sem dúvida, deve continuar enquanto não proscrevermos o cárcere da sociedade.

A tese de que "quanto pior for, melhor será" que se tenta forjar à realidade prisional, em geral professada por interlocutores sensasionalistas a fim de proteger do jeito que for os bens que possuem - e, tal discurso, sobretudo pelos meios de divulgação que se valem, acaba sendo

\footnotetext{
${ }^{207}$ Para C.R Bitencourt, seguindo uma vasta literatura que busca estabelecer limite às políticas ressocializadoras como demonstração da importância que oferecem ao tema, o tratamento ressocializador mínimo teria como pedra-e toque o oferecimento ao delinquente de elementos que o ajudem a "levar uma vida sem cometer crimes". (Bitencourt. Op. cit, p. 124).
} 
reproduzido acriticamente por grande parte da massa de cidadãos - já está comprovadamente fracassada em seus efeitos humanos e sociais. Ela demanda altíssimos custos de contenção, nenhuma certeza de segurança social e, o que é pior, promove a degradação da pessoa humana em detrimento dos princípios tão caros que o constitucionalismo moderno houve por bem positivar.

A emergência do terrorismo e a reação do Estado frente ao mesmo, justificando qualquer forma de intervenção ainda que motivada por argumentos meramente indiciários e fragmentários, ao lado da difusão de certos conflitos sociais decorrentes de temas afeitos à imigração, ao multiculturalismo e à liberdade religiosa, e a difusão destes enfrentamentos para os recôndidos da classe média, enfim, estas e outras questões atinentes a conflitividade social contemporânea contribuíram para a promoção de um grande alarme social, de uma "cultura do medo" nas palavras de D. GARLAND ${ }^{208}$, que provocaram nos últimos anos importantes “contra-reformas" penais e penitenciárias.

Dentre elas se destacam a edificação maciça de cárceres de máxima segurança - respostas políticas ao medo que se valeram do modelo supermax californiano conhecido como Perican Bay, edificada em 1989 e considerada o ícone de uma nova safra de presídios construídos por todo o mundo a partir da dos anos 90, e com eles a renúncia mais ou menos explícita a todo e qualquer projeto ressocializador ${ }^{209}$.

${ }^{208}$ Cf. Garland. D. Op. cit, p. 53-54. Segundo Fernando Gil Villa (La delincuencia e su circusntancia. Sociología Del crimen y la desviación. Valencia: Tirant lo Blanch, 2004, p. 120), a globalização também exerceu grande influência na exasperação do controle penal e na conseqüente autorização pela opção se supersegregação: "É evidente que a globalização apresenta repercussões na estrutura e no alcance da delinquiência. (...). Um mundo global é um mundo altamente móvel e instável, a ponto de novos setores da população seres vistos como ameaça da ordem social. E também é a globalização que inspira o sistema penitenciário, em especial ao propor o modelo de penitenciária californiana de Perican Bay, donde os reclusos estão praticamente isolados sem ter nada a fazer e nem ninguém para se comunicar. Ficaram longe as House of Correction em que o trabalho era utilizado para disciplinar os presos. A técnica aplicada na era da globalização, que soa como um slogan, seria a imobilidade (...)."

${ }^{209}$ Beiras, Iñaki Rivera. Lineamientos garantistas para uma transformación radical y reduccionista de La cárcel (uma visión desde España). Delito y sociedad. Revista de Ciencias Sociais. n. 14. v.9. 2000, p. 25. 
Apesar de ser uma utopia pretender ressocializar o indivíduo no cárcere, como lembra Baratta $^{210}$, há uma preocupação que justifica a manutenção do princípio ressocializador e mais ainda, impõe a necessidade de redefinir o seu conceito. Isso se deve à necessidade de se combater uma tendência hoje dominante na nova penologia estadunidense, que adota o discurso humanitário da pena investindo-o nas finalidades de inoucuização e intimidação do delinquente, eis que considera obsoleta a idéia de ressocialização.

Por outro lado, a idéia de que "quanto melhor for, pior será", paradoxalmente professada por setores ligados à intelectualidade e à esquerda política e, portanto, presumidamente, mais afeitos à crítica, preferem manter o cárcere "como está", sob a alegação de que os projetos que visam a humanizar o ambiente prisional têm o condão, na verdade, de legitimar a prisão.

Enfim, difícil dizer quais dos discursos, que chegam por vezes a se confundir, é o mais hipócrita. Se aquele que adota uma postura dura para assegurar a manutenção do estado de coisas que lhe é favorável, ou, por sua vez, o que opta pelo imobilismo intelectualizado e que, ao não propor nada, não fazer nada, sob a alegação de assim desconstruir o sistema, faz sim ampliar o sofrimento dos que diariamente se vitimam no cárcere e, até que o sistema solape (sabe-se lá quando e se isso ocorrerá), provavelmente já estarão abaixo das ruínas.

Disto se depreende que não há contradição entre se defender a ressocialização enquanto tolerância, na condição de mecanismo manutenção de um mínimo de humanidade no cárcere e lutar para que o cárcere seja proscrito da sociedade. A tolerância, portanto, tanto em sua manifestação indulgencial como na forma de um comportamento resignado, representa o limite da ressocialização e também o seu ponto distintivo com a reintegração social. Se a ressocialização, enfim, é caracterizada por uma postura de tolerância, a reintegração social tem na compreensão o mote de suas abordagens no cárcere. E há muita diferença nisso.

\footnotetext{
${ }^{210}$ Baratta. Op. cit, p. 140. O sistema penitenciário contemporâneo, de tradição política estadunidense, pode ser comparado a um "novo holocausto", como retratou o norueguês Nills Christie (Apud, Beiras, p. 24, nota de rodapé n. 2).
} 
A ressocialização pautada pela tolerância e não no seu sentido de mera indulgência, mas como uma experiência de resignação perante o outro (o infrator) já é algo superior ao menosprezo e a depreciação que orientam as propostas retributivas e neutralizadoras, atualmente tão alardeadas, sobretudo no picadeiro da política. Mas, o fato de ser melhor do que algo nitidamente aviltante não pode ser uma circunstância que impeça a construção de novas referências, mais humanas e capazes de concretizar uma experiência de alteridade, ainda que no cenário penitenciário.

A idéia de tolerância, de ressocializar o infrator como demonstração de aceitação, tal como ele é, ainda é fraca. Não é possível que alguém verdadeiramente ingresse no universo alheio, que possa, de alguma forma, colaborar para o seu crescimento enquanto ser humano, se a intervenção não preconiza uma entrega dual, uma disposição de conhecer e compreender bilateral.

E mesmo nos consultórios se tem hoje a noção de que a maioria dos pacientes necessita muito mais de alguém que interaja com eles, que viva, ainda que momentaneamente, as suas angustias, que sofra e se emocione com seus problemas - que, não raro, se apresentam como fatores de base nas manifestações patológicas - e não simplesmente seja, quando muito, um ouvinte indiferente e desinteressado em compreender a história escrita por trás dos fatos.

Voltando ao contexto penitenciário, é sabido que a escassez de recursos materiais, as péssimas condições dos presídios, o reduzido número de técnicos e os baixos salários a eles oferecidos são elementos capazes de dificultar, ou mesmo inviabilizar, qualquer trabalho de ressocialização. Então o que resta? Resta o aspecto humano, que subsiste até mesmo em contextos iguais ou até piores aos encontrados nos cárceres. Subsiste a vocação que somente o homem é capaz de desenvolver, uma vocação ao diálogo. E com base no diálogo, na compreensão plural, o homem é capaz de estabelecer relações que superem a condição de 
tolerante-tolerado, para se espraiar num campo que CORTELLA ${ }^{211}$ considera um estágio além. E este estágio é o do acolhimento.

"Há uma diferença entre tolerar que você não tenha as mesmas convicções que eu - sejam religiosas, políticas ou outras - e acolher suas convicções. Porque acolher significa que eu o recebo na qualidade de alguém como eu. (...) Do ponto de vista ético, a noção de acolhimento supõe que o outro não seja visto como forasteiro ou como um estrangeiro, não seja visto como alheio. É a perspectiva de entender o outro como outro e não como estranho.”.

É neste horizonte de acolhimento, e não de tolerância, que se erige a idéia de reintegração social. A proposta por uma "alternativa radical" não deve ser confundida com qualquer estratégia para legitimar o cárcere, mas tem o escopo de fornecer respostas à crise no campo da penologia, além de considerar que a própria pena e também o cárcere são um fato, uma realidade palpitante e angustiante.

A prática penitenciária que se desenvolve sob as diretrizes do tratamento penitenciário e da ressocialização se orienta, nas duas perspectivas, por um predominante olhar analítico (clínico, cirúrgico) do homem encarcerado e tenta através de suas observações desfigurar a totalidade do Ser para que, com a fragmentação, possa assim promover uma ideal readequação das partes de acordo com uma ordenação previamente estipulada.

Tais propostas também são redutoras, pois acreditam ser possível apreender a realidade "microcosmica",212 da pessoa, ao mesmo tempo que partem de uma idéia dedutivista do homem segundo a qual ele poderia ser enquadrado em esquemas (biológicos ou sociais)

${ }^{211}$ Cortella \& La Taille. Op. cit, p. 29-31.

212 Buber, Martin. Do diálogo e do dialógico. Trad. Maria Ekstein de Souza Queiroz e Regina Weinberg. São Paulo: Perspectiva, 2007, p. 147. 
prontos. Esta tal "desmagicização"213 do humano seria uma circunstância apta a instrumentalizar a intervenção penal e apoderar do o encarcerado.

BARATTA $^{214}$, então, retrata uma analogia entre as funções do direito penal e a função do direito humanitário e do direito de guerra para explicar seu magistério no contexto da Reintegração Social: ambos (direito humanitário e o direito de guerra) possuem o objetivo de limitar e regular, quanto possível, a violência advinda do conflito armado sem que esta limitação e regulamentação signifique, isoladamente, que se trate de legitimar a guerra ou contribuir para a sua legitimação.

A Reintegração Social, neste horizonte, desponta como um princípio que tem o escopo de minimizar os efeitos negativos do cárcere, tanto para os detentos quanto para a sociedade. $\mathrm{O}$ enfrentamento do problema carcerário deixam de ser buscado exclusivamente no interior do próprio cárcere e se volta também para fora dele, para a sociedade, a fim de convocá-la a partilhar o sofrimento que ela também ajudou a edificar. É enquanto criação social, o cárcere há de ser apresentado para todos os seus atores, a fim de que eles (sociedade intra-muros e extra-muros) reflitam os rumos que devem ou não assumir.

A alternativa denominada Reintegração Social, portanto, parte da premissa de que não se deve buscar a Reintegração do condenado através (attraverso) da pena privativa de liberdade, mas sim apesar (nonostante) e contra (contro) ela ${ }^{215}$. E este referencial demonstra claramente que a proposta encartada pela Reintegração Social não abdica da postura crítica de negar o cárcere, de contrariar o afastamento social sem que isto represente afrouxamento de suas propostas concretas.

\footnotetext{
${ }^{213}$ Idem, Ibidem.

${ }^{214}$ Baratta. Op. cit, p. 142.

${ }^{215}$ Idem. Ibidem, p. 140.
} 
Não se trata apenas de reclamar condições materiais dignas, como cárceres mais humanizados, com espaços para atividades à ressocialização. É preciso, e possível, ir mais longe para buscar condições de existência que não possam anular o homem enquanto pessoa. A justificativa da Reintegração Social será, então, promover uma abertura do cárcere para a sociedade e da sociedade para o cárcere, a fim de produzir uma gradativa cultura de liberalização social do próprio cárcere ${ }^{216}$.

A Reintegração Social se concretiza como uma proposta, ou conjunto de propostas, que se aglutinam em torno de uma postura compreensiva, plural e dialógica perante o fenômeno criminal, mas não apenas a ele, e sim a toda e qualquer seara da vida. Quando BARATTA fala que a idéia é pensar além do cárcere, o que quer dizer é que o cárcere há de ser encarado como um evento circunstancial, e exatamente o seu caráter provisório e não estruturante há de ser de todo secundário no contato entre as pessoas, dentro do cárcere ou fora dele. Trata-se de uma proposta capaz de transversalizar os mais variados aspectos da vida humana, e dos quais o encarceramento é apenas uma pequenina parcela ${ }^{217}$. E exatamente este caráter multifacetado que exonera da Reintegração Social o jugo do cárcere enquanto ratio essendi, ou seja, como sua razão de existência.

\footnotetext{
${ }^{216}$ Rivera Beiras. Op. cit, p. 27.

${ }^{217}$ Importa aclarar para o leitor que o controle social exercido pelo sistema penal é apenas um dentre as várias modalidades que tanto o Estado quanto a sociedade disponhem para sancionar os desvios perante as normas. Quando se pontua que a reintegração social não é uma proposta exclusiva do cárcere, se está querendo afirmar que sua base teórico-filosófica pode ser implementada em diversos campo que não apenas o do controle exercido pelo cárcere. Um exemplo de aplicação da idéia de reintegração social fora do cenário penitenciário ocorreu no HC/USP, no Projeto de Apoio Psicoeducativo para Pacientes Psicóticos (Proapse), desenvolvido pelo Instituto de Psiquiatria da FMUSP. A idéia central é fornecer uma experiência de diálogo entre os pacientes e seus cuidadores, rompendo alguns estigmas que eram alimentados dentro das casas das famílias, como a premissa de dependência e de temor para com os pacientes - fato que segundo um dos membros da equipe tinha o efeito de segregar e infantilizar o doente. Considerando o grupo como a "chave" para a reinserção social do paciente, assim declarou o médico psiquiatra e membro da equipe Rodrigo Leite " O próprio grupo troca informações e compartilha problemas e soluções ajudando na melhora de todos os envolvidos. O sentimento de solidão e insegurança, que são muito presentes nessas pessoas - tanto pacientes, quanto cuidadores - diminuem e são substituídos por uma sensação reconfortante de apoio, solidariedade, confiança e auto-controle." Cf. <http://gazetaweb.globo.com/v2/noticias/texto_completo.php?c=204071> Acessado em 24.02.2011.
} 
De maneira frontal, esta simples idéia rompe com uma tradição histórica do positivismo criminológico, assentada na fórmula de que grande parte dos criminosos ou seriam portadores da "Marca de Caín" (tratamento penitenciário) ou seriam pecadores (ressocialização indulgente) ou simplesmente desviados (ressocialização tolerante). Em comum a estas abordagens está a preocupação de que tudo haveria de ser feito aos transgressores, seres errantes, e nada deveria ser atribuído à sociedade; um grupo de premissas que absolvia a sociedade pelos criminosos que tinha, pelas relações que permitia e pela promiscuidade com que aquiescia. Mas a ela, absolutamente nada deveria ser feito. E este papel neutralizante alimentado pela própria cultura social não da percepção atenta de A. BARATTA ${ }^{218}$ :

“Apenas uma sociedade que pode gerenciar e resolver, sem reprimir, os próprios conflitos e a superar a violência estrutural pode enfrentar com sucesso o problema da violência individual e do delito. Somente superando a violência estrutural na sociedade se poderá superar a violência institucional do cárcere. Durante o caminho que conduz a esta superação o cárcere pode se transformar em um laboratório de produção do saber social indispensável para a emancipação e para o progresso da sociedade."

Com as abordagens simplistas de personificação dos males ou dos erros sociais se permitiu a evolução de um arcabouço nitidamente ideológico em torno da "questão penitenciária", cuja pretensão estaria perfeita no momento em que conseguisse explicar a criminalidade a partir do homem capturado pelo sistema. Esta inclinação para explicar a dinâmica da criminalidade seria válida quando utilizadas como fundamentos teóricos pelas estratégias de intervenção no homem encarcerado, para um contexto mecanizado e que, por isso mesmo, prescindiria de qualquer consideração ética da conduta. A liberdade humana, então, seria uma grande falácia eis que todos os fenômenos estariam submetidos a processos de quantificação e

${ }^{218}$ Baratta. Op. cit, p. 148. 
geometrização, em estrita obediência às relações de causalidade necessárias, automáticas e previsíveis.

Eis a diretriz do positivismo criminológico, calcada numa concepção reducionista e desacreditada do homem, mas que apresentava o "ganho" de ser racional, na medida em que preconizava respostas fáceis a questões por demais complexas. Foi uma teoria que, ao se apoiar numa doutrina filosófica própria dos corpos inanimados, negligenciou que o homem não é uma matéria petrificada, mas se trata de um conteúdo vívido e pulsante. A redução do homem e da convivência humana a um conjunto de leis universais e determinadas inverte uma regra de ouro: a de que não é o universo que anima o humano, mas exatamente o contrário. $\mathrm{O}$ melhor a considerar é que universo não protagoniza o humano, mas vive com ele uma relação de constante inter-ação; não constrói o homem, senão que é construído pela ação humana, que por sua vez se reconstrói através deste processo.

O homem dialoga com o universo, numa relação mútua de criação e recriação, onde nem um nem outro está definitivamente acabado, mas estão em constante redescoberta. As leis físicas do universo, desta feita, não são capazes de amordaçar o comportamento humano, assim como o homem não pode interromper por completo o fluxo do universo, mas o influencia e tenciona mudanças. Há, em verdade, uma relação de complementação e não de determinação. De uma perspectiva transcendente se pode extrair que o universo foi criado para ser a casa do homem e não a sua causa final.

É certo que o universo impõe restrições ao homem, mas elas nunca serão capazes de subtrair por completo a identidade enquanto marca humana e, portanto, a liberdade há de ser um recôndito sempre presente no contexto humano. Enquanto ser ético, pode ele se libertar das causalidades, apesar de estar em inegável contato com elas. 
Toda e qualquer pretensão de amesquinhar este ponto será perigosa e não passará de um sofisma, de uma "ilusão da verdade, que, embora simule um acordo com as regras da lógica, apresenta, na realidade, uma estrutura interna inconsistente, incorreta e deliberadamente enganosa". ${ }^{219}$ E é preciso reconhecer nesta liberdade, que não cessa por inteiro em razão do encarceramento, o local onde o humano se fará integrado aos demais, onde ele poderá realizar a ação exclusivamente humana, que é o diálogo 220 .

Pelo exposto, resta consignar que a necessidade de se insistir na diversidade dos conceitos, além de sua importante influência teórica, guarda uma relevância ainda maior na retomada de uma postura mais animada, esperançosa, não em relação à instituição, mas sim quanto às pessoas que lá estão, junto com as que não estão. A desintegração promovida pelo encarceramento, o desapossamento do lugar social que cada um ocupa, deixa um vazio que apenas sensivelmente pode ser sentido. E se se pretende avançar na compreensão do crime, é indispensável dotar todos os interlocutores, todos os interessados, portanto, toda a sociedade, da devida responsabilidade de assumir o seu papel no inter-jogo social, na sina da vida que nos é própria mas que também afeta aos outros.

${ }^{219}$ Conforme definição de sofisma expressa no Dicionário Eletrônico Houaiss, 2001.

${ }^{220}$ Não desconhecemos as razões do pensamento contrário, denominado de determinista, e muito menos a sua importância da filosofia e na psicanálise, por exemplo. Todavia, a opção que norteará este tratablho é mais coerente com a tese do livre-arbítrio, com os temperamentos que mesmo a doutrina teológica mais tradicional não deixa de reconhecer. Para os deterministas, a vontade não seria espontânea nem aleatória, eis que sua escolha seria apenas uma opção determinada por eventos que lhe foram anteriores. Para a concepção determinista de liberdade, cada estado de coisas restaria inteiramente necessitado e, por conseguinte, estabelecido por um encadeamento dos estados de coisas precedentes. Exatamente sobre este fundamento que a psicanálise repousa o seu arcabouço científico. Desde seus primeiros escritos, Freud asseverava a inexistência de descontinuidades na vida mental, ou seja, o próprio querer poderia ser explicado pela investigação das experiências pretéritas e, neste escopo, as necessidades assumiriam local de destaque. Ora, a cisão entre querer (velle) e poder (posse) tão aclamada pelos filósofos outrora mencionados perderia espaço no seio das empreitadas psicanalíticas. Segundo a visão compatibilista, o livre arbítrio emerge em um universo sem incertezas metafísicas, ao que adviria de um conjunto possível e provável de causas finitas. Esta corrente também ficou conhecida por soft determinism, expressão cunhada por William James. James foi um dos mais conhecidos teóricos compatibilistas e renomado filósofo e psicólogo norte-americano do início do Sec. XX. Na filosofia, James ficou conhecido como um dos fundadores do pragmatismo. No campo da psicologia, fundou o funcionalismo e apresentou a primeira sistematização genuinamente americana da ciência psi. Para essa escola, altamente pragmática (tal qual o sistema norte-americano da época), importava responder "o que faziam os homens" e "por que o faziam". Para responder a isso, elegiam a consciência como centro de suas preocupações, buscando a compreensão de seu funcionamento. Bock, Ana Mercês Maria et al. Psicologias: uma introdução ao estudo da psicologia. 13a edição. São Paulo: Saraiva, 2002. p 27 
Assim, a Reintegração Social tem o escopo de apresentar uma nova proposta para a solução idealista firmada pela ressocialização, baseada na pura repetição de condutas desejadas e em perfeita conformidade às quais nem mesmo os seus propositores são capazes de atuar; tratase, portanto, de lutar contra uma imposição "contrafactual" que não pode ser atingida, sobretudo através da privação de liberdade. Por outro lado, a Reintegração intenta evitar a solução cínica do problema, aquela tão em voga na nova penologia estadonidense e que consiste em abandonar por completo qualquer empreendimento de compreensão a partir do crime, mas apenas tratar de neutralizá-lo ou de exorcizá-lo por meio da intimidação específica do infrator, com a consequiência de "jogar fora o bebê junto com a água",221, renunciando a qualquer reclamo humanitário e garantista que somente adquirem efetivo espaço dentro do conceito de Reintegração Social.

As atividades promovidas no cárcere devem, por fim, na medida do possível, se afastar da sombra de frustração e do sofrimento que a instituição carrega e reproduz através da sujeição e objetificação das relações humanas, para dar espaço a participações democráticas que tenham o escopo de oxigenar o ambiente carcomido pelo isolamento, pelo uso desmedido do poder como forma de subjugar os presos às férreas regras da administração. Uma experiência democrática, uma gestão partilhada entre os atores do cárcere, tende a promover uma experiência que transcendente ao próprio cárcere e, por isso, afinada com o princípio da Reintegração Social.

${ }^{221}$ Esta expressão provém de um conhecido ditado inglês que diz "Don't throw out the baby with the bath water" (Não se deve jogar fora o bebê junto com a água do banho). Em suma, esta frase repetia a tempos pretéritos, quando as famílias tinham por hábito tomar poucos banhos durante o ano, e quando o faziam (e isso ocorria em banheiras de metal) seguiam um ritual no qual o bebê seria o último a ser banhado. Portanto, a água suja deveria ser separada do bebê para que ele não se perdesse na sua turvação. Em essência, tal idéia leva ao contexto de que não se deve jogar fora o bom e o ruim, e isso se aproxima do adágio popular que diz sobre a importância de "separar o joio do trigo". Aplicado da forma como foi, e em se tratando do cenário penitenciário norteamericano, a expressão quis informar que o cárcere não distingue entre o bom e o ruim, ou seja, não individualiza, mas despersonaliza as pessoas ou, por outro lado, retrata o local onde se jogam os restos: a lixeira) 
As diferenças até então apresentadas entre os conceitos de tratamento penitenciário e ressocialização, de um lado, os quais foram inseridos dentro do gênero denominado de Técnicas de Intervenção no Homem Encarcerado, e o princípio de Reintegração Social, de outro, cujas linhas de atuação serão, daqui em diante, concebidas sob o título de Ações de Promoção do Inter-humano ${ }^{222}$ podem ser assim sintetizadas: (i) quanto as raízes históricas; (ii) quanto a abrangência; (iii) quanto aos objetivos; e (iv) quanto aos fundamentos; (v) quanto às justificativas.

As raízes históricas do tratamento penitenciário e da ressocialização remontam aos princípios de direito penal canônico e à tradição criminológica positivista; a Reintegração Social tem seus primeiros registros no final da década de 80, num momento de crise de paradigmas do sistema penal e, portanto surge como um misto de resistência e mudança sob a influência da criminologia crítica e do constitucionalismo social, orientada ainda no campo criminal pelos ideais do garantismo penal.

Quanto à abrangência, as técnicas de intervenção no homem encarcerado se restringem ao cenário criminal e, exatamente por isso, sofrem daquilo que ORTEGA Y GASSET chamou de barbárie da especialização, ou seja, julgam que o mundo se reduz ao crime (pois da realidade, só absorvem uma faceta) e concebem, cada uma a seu modo, o criminoso como alguém diverso, inclinado a novos desvios e, portanto, objeto de atenção e cuidados; é o que denominamos de ensimesmamento penitenciário. As ações de promoção do inter-humano vão além do cárcere e da esfera criminal, mas se espraiam por todas as relação humanas; aqui, não há barbarizações, ensimesmamentos, exatamente pelo fato de a busca não ser situada mas sim aberta; não se procura o criminoso, o pobre, o rico, o homem, ou a mulher; o inter-humano

\footnotetext{
${ }^{222}$ Este termo "inter-humano" é tomado de empréstimo da filosofia dialógica de Martin Buber, e será mais bem explorado à frente. Por hora, quadra salientar que o plano inter-humano, para Buber, é também chamado de plano do "Entre": ele não se reduz a um interlocutor (o "eu") e não ao outro (o "tu"), não repousa nem em um nem em outro, mas faz emergir deste encontro entre o eu-tu um novo horizonte, o entre. É somente neste plano que o homem se realiza enquanto tal, que se encontra com seu semelhante fora de si, num local que não pertence a nenhum dos dois, mas que se fará comum à medida que o diálogo for capaz de possibilitá-los um empoderamento dual.
} 
toca a todos e possibilita a construção de pontes capazes de ligar as pessoas enquanto totalidades.

Os objetivos do tratamento penitenciário e da ressocialização são manifestos: o primeiro, de matriz médico-psicológica, tem por objetivo propor mecanismos de cura ou atenuação do quadro criminal; a ressocialização, a depender da diretriz (máxima ou mínima) vai pretender introjetar valores no indivíduo ou ofecerer modelos de conduta para que ele, voluntariamente, se apóie em seu retorno à sociedade. O objetivo da Reintegração Social é promover o encontro humano; é possibilitar que o plano do Entre presente nas relações humanas, dentre elas as de caráter penitenciário; é edificar pontes que liguem um ao outro e permitam um livre transito nos dois sentidos; em suma, é oferecer uma oportunidade para que o homem conheça o outro à medida em que vai conhecendo a si mesmo.

Quanto aos fundamentos, tanto o tratamento quanto a ressocialização guardam em comum uma visão fragmentada e de um homem degenerado; ele não raro é um suspeito com quem se tem uma postura defensiva. A Reintegração Social se fundamenta na crença no homem enquanto ser criativo e capaz de se redescobrir no outro. Trata-se do embate de duas visões antagônicas de homem: de um lado emerge o padrão de homem hobbessiano e de outro, na construção que ora empregaremos, o modelo rousseauniano.

Quanto às justificativas, às primeiras teorias surgem como tais o interesse de apossamento do homem, de submissão, de jugo; fruto do homem temido com que acredita lidar. A Reintegração Social labora com a idéia do diálogo, que só pode existir no plano da simetria, da horizontalidade e da autonomia, e o faz por entender que os homens são idênticos em sua capacidade original, inata, de se dispor ao outro e a si mesmos. 
Este é, enfim, o cenário que indubitavelmente não permite qualquer tipo de confusão, salvo para fins retóricos e ideológicos, entre as idéias de tratamento penitenciário,ressocialização e Reintegração Social.

A Reintegração Social foi apresentada em seu aspecto mais geral, apenas visando a confrontar suas diferenças com os conceitos de tratamento penitenciário e ressocialização. Com isto, se tem preenchida a primeira parte da empreitada lançada como objetivo da pesquisa, qual seja, a de investigar as possíveis diferenças entre os conceitos mencionados. Elas de fato existem e precisam ser levadas em conta, pois vão muito além do simples jogo de palavras à disposição do interessado. Antes disso, os termos guardam substratos singulares, que podem se aproximar em algumas circunstâncias, mas que não permitem usos indiscriminados sob pena de subverterem a prática à qual se prestaram como referencial.

A segunda etapa lançada no objetivo estava em caracterizar o conteúdo do princípio da Reintegração Social. Esta tarefa passa, segundo o caminho que se está traçando, por um enfrentamento semântico e passa, na sequência, por uma abordagem sociológica para, então, ancorar na seara clínico-criminológica e, por fim, no cenário filosófico. É este o horizonte que se apresenta.

\subsection{IntegraÇÃo, DeSintegraÇÃo E REINTEgraÇão Social: HaRMonizando OS CONTRÁRIOS DA REALIDADE}

Não há nada de novo na afirmação de que o cárcere representa um obstáculo ao desenvolvimento humano, e assim também aos processos e experiências interativas que tal condição exige. Ao forjar um contexto artificial, estranho e hostil, a prisão tende a impor relações humanas contaminadas e distorcidas, pautadas pela sujeição e pela desconfiança que não raro se apresenta como uma "reserva de segurança" tanto para os que administram as instituições penitenciárias, quando para os próprios presos. 
Forma-se uma rede de relacionamentos precários, em que a marca passa a ser a assimetria. Este descompasso relacional acarreta (e isso não apenas no contexto do cárcere) uma identificação dicotomizada, na medida em que congrega interesses com base na equação excludentes/excluídos, e com polaridades que se alternam dinamicamente. Dentro deste cenário, as relações humanas tendem a se desenvolver no seio de interesses cindidos, que de um lado intensificam os laços entre os que se consideram iguais e, de outro, reproduzem a exclusão e acirram as disparidades entre aqueles que vislumbram entre si diferenças essenciais. É o rótulo, o estereótipo, a “embalagem” como caractere desagregador, em detrimento da unidade que remete ao conteúdo.

Surge, então, a estigmatização, mecanismo de afastamento imposto por um agrupamento social sobre outro(s) para reforçar a existência da unidade, de um lado, e da diversidade, de outro. Nas palavras de CAFFARENA ${ }^{223}$, o cárcere encerra o espaço de maior tensionamento destas marcas distintivas entre os homens, pois

"não existe um sistema melhor para estimular a solidariedade e coexistência de um grupo como a adversidade de um frente o outro. Esta autoidentificação no grupo não tem porque ser negativa, já que pode se dar, de igual maneira, uma atitude de apoio ou de rechaço ao desviado. Circunstâncias da própria ação, como pro exemplo o favorecimento por meio de campanhas em meios de difusão, podem produzir no cidadão médio um sentimento a favor ou contra o sujeito desviado, no qual com freqüência transcende a particularidade do próprio fato promovendo a identificação frente aos demais como um símbolo".

${ }^{223}$ Caffarena. Op. cit, p. 324. 
A este processo forjado de identificação entre semelhantes em torno do grupo H. MEAD ${ }^{224}$ denominou de solidariedade emocional agressiva. E um dos mais lúcidos exemplos de promoção desta forma de gregarismo pode ser encontrado no cárcere, quando os presos se sentem intimamente solidários entre eles, identificados na fragilidade e no estigma que lhes é comum, frente à sociedade que os marginaliza.

As percepções que se constroem sobre uma pessoa exercem um indiscutível papel na percepção que ela própria passa a construir sobre si mesma, em tal sentido que a autopercepção, o autoconceito e até mesmo a autoestima se entrelaçam a este conjunto de expectativas que os grupos sociais depositam ou subtraem da pessoa. É dizer: as expectativas socialmente construídas podem ser introjetadas pelo indivíduo na forma de única perspectiva verdadeira, e com isso o sujeito rotulado passa a secundarizar a imagem de si em decorrência da imagem que lhe é conferida ${ }^{225}$.

Vale ressaltar o destaque feito por D. GARLAND acerca da proliferação, em território americano, de procedimentos judiciais de notificação compulsória à comunidade acerca da soltura de presos condenados por crimes sexuais que, diga-se de passagem, haviam sido libertos de forma legítima e obtido, portanto, o direito de retomar suas vidas de forma regular. Fato semelhante ocorreu no Brasil, por exemplo, com a promulgação da Lei 12.258/2010 que estabeleceu o procedimento de monitoramento eletrônico para presos do regime aberto.

E tudo ocorreu sob o nobre argumento de se tratar de uma "medida necessária para a segurança da sociedade”. Estes argumentos que apelam para uma vitimização coletiva. Como destacou D. GARLAND ${ }^{226}$ :

\footnotetext{
${ }^{224}$ Apud. Caffarena. Ibidem.

225 Perez, Miguel Fernandez. El derecho fundamental a la reconstruccion de la persona em las prisiones. Eguzkilore. Cuaderno del Instituto Vasco de Criminologia. n.8. San Sebastián, 1994, p. 151.

${ }^{226}$ Garland. Op. cit, p.54-55.
} 
"A percepção de um público amedrontado e revoltado teve grande impacto no tipo e no conteúdo das políticas, nos anos recentes. O crime foi redramatizado. A imagem aceita, própria da época do bem-estar, do delinquente como um sujeito necessitado, desfavorecido, agora desapareceu. Em vez disto, as imagens modificadas para acompanhar a nova legislação tendem a ser esboços estereotipados de jovens rebeldes, de predadores perigosos e de criminosos incuravelmente reincidentes. (...). Qualquer atenção aos direitos ou ao bem-estar do agressor é considerada como defletiva das medidas apropriadas de respeito às vítimas. Cria-se um jogo político maniqueísta, no qual o ganho do agressor significa a perda da vítima, e 'apoiar' as vítimas automaticamente quer dizer ser duro com os agressores."

Há alguma proposta capaz de reduzir os danos que esta assimetria acarreta? É possível haver uma aproximação horizontal entre os atores que gravitam em torno do cenário penitenciário, isto é, sociedade, administração penitenciária e os presos?

Se o cárcere é uma instituição essencialmente humana, que sobrevive por meio das relações desta natureza que lhe dão suporte, torna-se indeclinável enfrentar indagações deste teor, antes de se assumir uma postura fatalista E se grande parte dos problemas do cárcere decorrem da cisão que ele empreende, importa pensar, ainda que na contramão dos diagnósticos que são apresentados, numa experiência de integração ou re-integração ${ }^{227}$ que

\footnotetext{
${ }^{227}$ A investigação terá como base, inicialmente, a análise do termo "integração" e seus significados léxicos. Não se trata de abandonar a idéia de reintegração, mas sim de construí-la a partir do nome que lhe fornece o conteúdo principal, para em seguida empreender a abordagem propriamente penitenciária, e que por tradição e influência das chamadas doutrinas "re", acabou transportando o prefixo para o conceito de integração. Assim, a construção partirá do essencial, até porque na literalidade, re-integração á ação de reintegra; voltar a integrar. Quadra registrar que o termo Reintegração Social aparecerá sem maiores explicações no texto, pois deve ser compreendido como uma extensão de integração social, o que desonera uma contextualização intermediária entre os dois termos, exatamente pelo fato de a única diferença entre eles é o fato se que reintegração é termo consagrado no campo penitenciário e integração não. Fora isso, em essência, podem ser tidos como sinônimos.
} 
possa tencionar alguma medida de esperança no sentido de reduzir os transtornos que a experiência do cárcere acarreta no seio do humano.

O termo integração, tomado em seu aspecto léxico, se sustenta na idéia de assimilação, de incorporação $^{228}$. A idéia supõe alguma aproximação entre as partes. Seja no campo patrimonial, onde o sujeito não raro se integra com objetos inanimados, seja no contexto social, quando então surge uma dinâmica da inter-relação, há uma rede que se apresenta. O que muda, contudo, é a natureza dela.

Nas relações patrimoniais, o vínculo se firma a partir de interesses unifocais (de origem e destinos predefinidos) e que somente interagem na medida da vontade do sujeito solitário. Não há outra dinâmica que não aquela imposta pelo ator circunscrito, exatamente por ser ele o único a ditar as regras do jogo. Mais propriamente, dita as regras e joga com elas. O envolvimento, neste caso, é meramente instrumental e se desdobra numa relação de sujeição e empoderamento.

Enquanto sujeição, a integração se impõe a partir de um contexto de objetificação e dependência. É uma relação entre sujeito e objeto, apenas, e como tal prescinde de acordos ou ajustes necessários a atualizar os vínculos que podem brotar do processo interativo. Até por isso, se pode dizer que a integração, como ato de sujeição é estática, imobilizadora e dominadora. Ela se liga à idéia de posse, de domínio de alguém sobre alguma coisa (ou alguém). O conhecimento que a orienta é sempre apriorístico, abstrato e distante, e isso a caracteriza como um saber castrador por excelência.

A assimilação que se desdobra é fragmentada, pois em se tratando de uma relação de coisificação, o sujeito pode concebê-la de forma a apreender apenas os aspectos que lhes são

\footnotetext{
${ }^{228}$ Pesquisa do termo "integração" realizada no Dicionário Eletrônico Houaiss, 2001.
} 
úteis e, em seguida, tende a descartar todo o restante. Se não descarta, por não querer ou não poder assim agir, o sujeito transforma a coisa e faz dela algo valioso ao seus olhos, e só a eles. A incorporação é meramente instrumental, pois na verdade o que se pretende é extrair deste algo, desta coisa que é absorvida, o que ela tem a dar, os benefícios, a utilidade que ela ostenta. Sem isso, ela não representa algo que valha a pena.

No segundo caso, isto é, na integração mediada por uma relação intersubjetiva (sujeitosujeito), relação propriamente social, as diretrizes são outras. $O$ envolvimento não se estabelece como ato de autoridade, nem pretende satisfazer os interesses definidos antes mesmo da experiência (que, por si, é plural).

A integração social faz do envolvimento a sua razão, a sua finalidade. Não intenta dominar, mas com-partilhar; não se fixa em diretrizes prontas, mas delas se vale para conhecer a realidade e com ela recriar novos saberes; não encerra uma postura ensimesmada das coisas, mas se abre a horizontes ainda desconhecidos; não se conserva num conjunto inabalável de verdades, mas as aceita como válidas na medida em que permite avançar no encontro de outras; não se pauta por uma aproximação fria, mas permite a inquietude e a angústia como próprias do crescimento humano; foge de concepções lineares e simplificadas das coisas, a fim de forjar uma compreensão tão complexa quanto a própria existência, partindo de uma contextualização multifocal.

Em resumo, a integração social representa verdadeiramente um processo de inter-ação, na medida em que exerce sua dinâmica por meio de uma ação conjunta e combinada, porém não orquestrada, que se faz com os avanços e retrocessos comuns ao crescimento humano. A postura, aqui, não é de acomodação, mas de inquietação. É a vocação pelo encontro como processo de dialética social, pois a aproximação de dois ou mais sujeitos há de projetar um novo cenário, fruto da fusão de perspectivas diversas, mas que se estabelecem mutuamente sob a vontade de se compreenderem um ao outro. 
Neste cenário, o silencio cede espaço para o diálogo, para o entendimento - que não se constrói através da escuta inerte, mas se desenrola por meio da crítica compreensiva, construtiva e edificante. $\mathrm{O}$ ser real que se busca conhecer surge pela disponibilidade que o envolvimento promove, e continuamente se redescobre em si mesmo e no outro. Nesse enredo, não há espaços para a sujeição, mas nasce uma relação de emancipação. Trata-se de um processo que favorece e promove a mais importante das liberdades: a de ser humano.

Ocorre que a integração pela sujeição não está restrita ao enredo meramente patrimonial, como uma leitura superficial da realidade poderia fornecer. Ela está também reproduzida em diversas relações sociais, sempre com o propósito de amesquinhar a humanidade do sujeito a fim de torná-lo objeto. Às claras ou de forma subliminar, a integração que aprisiona lança mão de suas artimanhas para justificar a privação do ser na forma de benefício. Trata-se, por conseguinte, de uma distorção da integração social.

É bem verdade que dessa relação podem surgem ganhos de lado a lado, especialmente se considerada a sensação de segurança que a dependência pode oferecer, mas eles são muito mais voltados a satisfazer o sujeito que as propõe do que aquele que foi reduzido a objeto. E esta relação predatória se recria, pois aquele que sujeita teme a rebelião do sujeitado, e isso faz com que mantenha sob sérias restrições os benefícios que oferece, cedendo sempre com cautela e reprimindo com voracidade. O teólogo FABIO DE MELO ${ }^{229}$ retratou muito bem este misto de segurança, temor e privação quando abordou a questão da diferença entre o sequestro do corpo e o sequestro da subjetividade:

"Sabemos que com o aprisionamento do corpo toda a subjetividade sofre também. Este sofrimento é imediato, porque é brutal. É o corpo

${ }^{229}$ Melo, Fabio. Quem me roubou de mim? O sequestro da subjetividade e o desafio de ser pessoa. $66^{\mathrm{a}}$ ed. São Paulo: Canção Nova, 2009, p. 36-37. 
que é roubado, levado de seu lugar e de seus significados. Já no sequestro da subjetividade nem sempre há sofrimento imediato do corpo. O que há é um sofrimento psicológico que, com o tempo, refletirá no corpo. Por ser um processo mais lento, o sequestro da subjetividade pode, num primeiro momento, ser sinônimo de prazer, satisfação, porque o corpo não é subjugado a maus tratos concretos, como no caso do sequestro da materialidade."

Quando a discussão é transportada para o campo penitenciário, em especial para as relações sociais nascidas a partir do encarceramento, não é difícil constatar a simplificação da convivência humana. Mais do que estabelecer formas prontas de comportamento, o encarceramento tende a promover a objetificação do humano quando impõe práticas que tencionam a desconfiança, o medo e o alheamento. Claro que a segregação, por si só, tende a fomentar este papel. Nessa medida, o cárcere em si se apresenta como obstáculo para a interrelação humana, para a integração social.

O problema não está em reconhecer no cárcere um mal, eis que inúmeros estudos já se debruçaram sobre esta premissa e confirmaram suas hipóteses. Não há novidade em vituperar contra o cárcere e seus efeitos. E apesar de todo espectro de aniquilamento que ele carrega, das pesadas críticas que arrasta e das vidas que priva, ele ainda permanece solidamente de pé. A questão a se enfrentar não está propriamente na implosão imediata do cárcere, mas sim na investida voltada a minorar os efeitos do encarceramento, a ilusão de segurança que ele oferece, de um lado, e os desdobramentos da privação, por outro.

A prisão talvez seja o maior e mais fiel símbolo da integração pela sujeição em massa - o faz por meio de suas Estratégias de Intervenção no Homem Encarcerado, e os seus efeitos estão por todos os lados, expondo as consequências de tal relação. Em um pólo figura a sociedade (mais propriamente alguns setores dela) que sujeita e no outro o preso enquanto sujeitado. 
Pode parecer plenamente vantajoso para a sociedade aplicar a pena, objetificar o preso, e se permitir a tranquilidade dos vencedores. Mas todo esse vampirismo cobra o seu preço, cedo ou tarde. Não há vencedores na lógica do encarceramento, mas apenas vencidos. Os rituais que se repetem nas prisões provam isso, e espalham seus horrores tal como dejetos lançados no ventilador.

É provável que esta mesma sociedade que pune não tenha se dado conta de que esta expropriação do outro a mantém tão monstruosa quanto a fera que ela diz enjaular. Se é verdade que a criatura toma a imagem e semelhança do criador, no caso, o objeto para com o sujeito que o objetifica, a fera está fora e dentro do cárcere, coexistindo no mesmo corpo social. "O mal-estar generalizado, os conflitos que caracterizam o microcosmo carcerário refletem fielmente a situação do universo social. O drama carcerário é um aspecto e um exemplo do drama humano" - disse Baratta. ${ }^{230}$

Partindo de uma perspectiva psicanalítica, a punição penal assumiria dois papéis inquestionavelmente interessantes: o primeiro seria o de legitimar, para quem pune, a prática dos mesmos atos praticados pelo criminoso, numa abordagem que aproxima e identifica, de forma cooperativa, os impulsos de quem pune e de quem é punido; o segundo surge quase para compensar o primeiro, já que aqui a sociedade necessita da punição enquanto oportunidade de autopunição e expiação dos sentimentos coletivos de culpa $^{231}$. E, como lembram os autores, "através do mecanismo da projeção, a coletividade transfere a sua culpa para o delinquiente e pune-se, punindo-o. É a teoria do bode expiatório, com tradições na criminologia psicanalítica" 232 .

\footnotetext{
${ }^{230}$ Baratta. Op. cit, p. 148.

${ }^{231}$ Figueiredo Dias e Costa Andrade. p. 204. Neste sentido, e analisando os "serviços" e os "desserviços" da pena privativa de liberdade Cf. Sá, Alvino Augusto de. Algumas ponderações acerca da reintegração social dos condenados à pena privativa de liberdade. In. Sá, A. A. Criminologia clínica e psicologia criminal. $2^{a}$ ed. São Paulo: RT, 2010, p. 141-143.

${ }^{232}$ Como adverte Sá (Algumas ponderações...Idem, p. 142), abordando o papel do criminoso neste trilhar psicanalítico: "O criminoso passa a ser então um concentrado de todos os males da humanidade, e a sociedade tem necessidade urgente de puni-lo severamente, prendê-lo, segregá-lo, pois assim estará punindo o que existe
} 
A sociedade necessita do cárcere, necessita dos presos, para, por meio deles, satisfazer sua necessidade de expulsar de si o que não presta e expiar suas próprias culpas. Talvez o processo possa ser compreendido da seguinte forma: $O$ encarceramento seria uma forma de expropriação (contrário de integração) de pessoas que estavam (ou deveriam estar) integradas à sociedade, isto é, que, na verdade lhe pertencem e devem estar incorporadas a ela.

O que urge fazer é desenvolver ações de Reintegração Social. Com isto, a Reintegração Social não teria como finalidade simplesmente tornar o cárcere menos cárcere (pois isto seria meio que simplista), mas construir toda uma trajetória de retorno, de re-incorporação do preso à sociedade, de retomada ou reconstrução de sua identidade, o mesmo se dizendo em relação à sociedade (ou dos segmentos da sociedade que vão ao cárcere). A Reintegração, na condição de relação emancipatória, teria condições de quebrantar estigmas por meio de uma aproximação efetiva entre os interlocutores, relação de subjetivicação, por assim dizer, cuja natureza seria de reconectar os pólos sociais em torno da unidade humana.

\subsection{REINTEGRAÇÃo SOCIAL, EXCLUSÃO E CRIMINALIDADE}

A Reintegração Social é herdeira e tributária da crítica criminológica e, com ela, aprendeu a se indignar perante as violações e, especialmente, diante das tentativas de encobrir os fatos através de singelos e frágeis argumentos. Assim, uma dimensão sociológica de Reintegração Social não pode deixar de olhar para a forma como, em geral, são selecionados os encarcerados.

de ruim dentro dela (e assim 'satisfazendo' o superego) e estará expulsando e mantendo longe de si, 'sob ferros', todas as suas coisas ruins." 
A história das prisões está à disposição para demonstrar que o cárcere sempre se prestou a justificar inúmeras formas de sujeição, travestidas de benefícios aos sujeitados, e que tinham o condão de naturalizar a idéia de punição enquanto medida de inclusão. Não uma inclusão propriamente pensada em oposição à idéia de exclusão, mas sim enquanto um de seus desdobramentos, processado por meios complexos e ambíguos. Nas palavras de Sawaia ${ }^{233}$ :

"A sociedade exclui para incluir e esta transmutação é condição da ordem social desigual, o que implica o caráter ilusório da inclusão. Todos estamos inseridos de algum modo, nem sempre decente e digno, no circuito reprodutivo das atividades econômicas, sendo a grande maioria da humanidade inserida através da insuficiência e das privações, que se desdobram para fora do econômico."

A existência e o funcionamento do cárcere fazem sentido na medida em que ele exerce o papel de instituição social localizada no último estágio do processo de inclusão social perversa; é o "guardião das sombras". Os seus muros e toda a sua magia não produzem a tal perversão, mas apenas a confirmam e intensificam. Sob este prisma, o cárcere não é o maior dos problemas, o que nem de longe quer dizer que seja a melhor das soluções: embora não o maior, é mais um dos problemas. E centralizar a análise em seu entorno tende a subtrair da atenção outras circunstâncias que compõem a essência da discussão, como, por exemplo, o conteúdo das relações humanas que se estabelecem antes, durante e depois do fenômeno do encarceramento.

A. BARATTA lembra que o cárcere não apenas reproduz as relações de desigualdade havidas no seio da sociedade como também se presta a assim fazer se valendo dos mesmos sujeitos

${ }^{233}$ Sawaia, Bader. Op. cit, p. 08. 
passivos que suportam tal relação ${ }^{234}$, e por isso, antes de se pretender analisar as pessoas dos excluídos seria mister se debruçar sobre a sociedade excludente, chegando assim à matriz do mecanismo de exclusão ${ }^{235}$.

JOCK YOUNG ${ }^{236}$ aponta algumas premissas comuns ao contexto de uma sociedade excludente: (i) existências de um núcleo central de privilegiados; (ii) estabelecimento de um cordão sanitário que separa a minoria privilegiada da periferia excluída; (iii) existência de um grupo periférico, que assumem os papéis de "bodes expiatórios" (chivos expiatorios). É possível extrair das colocações de Young que ele parte para uma análise que vislumbra a referência econômica e suas disparidades como o mais decisivo fator de exclusão. Portanto, as mais variadas formas de exclusão podem ser escalonadas abaixo da que mais aviltaria: a exclusão perante o sistema econômico. No mesmo sentido foi a manifestação RosÂnGELA SANTA $\operatorname{RITA}^{237}$ :

"Não querendo reforçar a relação direta e muitas vezes simplista entre criminalidade e exclusão social, o que se pode perceber é que as pessoas procedentes de classes com menor poder aquisitivo se tornam mais propensas à seleção da justiça criminal, e não à prática de infrações criminais."

Não é difícil demonstrar que a sociedade atual tolera e, mais ainda, estimula o enriquecimento despreocupado (acumulação de capital desmedida às custas da desgraça do outro), a qualquer custo; não há constrangimento algum no fato de acumular dividendos em causa própria, para

\footnotetext{
234 Baratta, Alessandro. Observaciones sobre las funciones de la cárcel en la producción de las relaciones sociales de desigualdad. In: Baratta, A. Criminología y sistema penal (compilación in memoriam). Montevidéo/Buenos Aires: Editorial Bdef, 2004, p. 365.

${ }^{235}$ Baratta. Idem, p. 371.

236 Apud. Villas. Op. cit. p. 123-124.

${ }^{237}$ Rita, Rosangela Peixoto Santa. Mães e crianças atrás das grades: em questão o princípio da dignidade da pessoa humana. Brasília: Ministério da Justiça, 2007, p. 38.
} 
gozo pessoal, ainda que tantos sejam os indivíduos que diariamente carecem do mínimo existencial para exercer uma vida digna. Em se tratando de uma sociedade carente, a imoralidade precisa ser velada, encoberta por uma rede de argumentos que façam dos aquinhoados um protótipo ideal de vencedor, um modelo a ser perseguido; já os despossuídos, por sua vez, são vistos ora como desvalidos, ora como estorvo; de qualquer maneira, a ideologia alicerçada para proteger o capital faz de cada um senhor de sua história, seja ela de sucesso ou de fracasso.

Os ricos não sentem nenhum remorso pelo carro excessivamente caro que possuem, o imóvel grosseiramente amplo que ostentam, as viagens internacionais que rotineiramente fazem (para compras, diga-se de passagem), os restaurantes caros que freqüentam, as roupas badaladas que usam, enfim, não se constrangem em ter tanto num país, como o Brasil, onde tantos tem tão pouco ou nada tem.

\begin{abstract}
"Se temos a dimensão da divida social implicada no valor, no símbolo dinheiro, poderemos entender que a acumulação de capital significa matar gradativamente de fome, gerar violência. E assim começamos corajosamente a perceber uma das grandes causas da chamada "violência'.,"238
\end{abstract}

${ }^{238}$ Pelizzoli, Marcelo. Fundamentos para a restauração da justiça. Resolução de conflitos, justiça restaurativa e a ética da $\quad$ alteridadeldiálogo. <w idcb.org.br/documentos/artigos040806/fundamentospararestauracaojustica.pdf, acessado em 24.02.2011. E neste sentido Elbert \& Balcarce (Exclusión y castigo en la sociedad global. Montevideo/Buenos Aires: BdeF, 2009, p. 27) foram muito felizes na exposição do exemplo: "Os poderosos bailam na cobertura do Titanic, enquanto os passageiros de terceira classe são adormecidos pelo ópio televisivo e audiovisual. Os privilegiados pela concentração de riqueza pretendem gozar de seus benefícios de maneira idílica e hedonista em seus iates, campos de golf e condomínios fechados, se alheando da degradação social que se multiplica nos seus arredores; consideram que seus privilégios são algo assim como um direito divino que lhes haveria sido concedido por razões de inteligência, capacidade profissional, ou algumas outras virtudes que se auto-atribuem. É fácil supor, então, o tipo de políticas de contenção que estes grupos têm a oferecer, assim como suas ideologias justificadoras; seguramente será a máxima contenção e rigor possíveis contra os desviados predatórios que perturbam a calma de seu paraíso consumista." 
A sociedade não pode prescindir da conflitividade social, pois seria utópica a tentativa de sustentar um consenso absoluto em torno da diversidade de temas que interessam à coletividade. E é, em geral, como forma de minimizar as angústias desse conflito ou quem sabe na tentativa de arregimentar um conjunto de artimanhas para forjar uma fluida e aparente pacificação social que se apontam alguns indivíduos como os causadores da instabilidade, relegando a eles o espectro de exclusão perante o restante do grupo, ilusoriamente tido como ordeiro.

É o que destaca C. R. BitencourT ${ }^{239}$ : "Desde o momento em que existam conflitos e diferenças de critérios, aparece imediatamente o marginalizado, ou seja, aquele a quem o poder constituído impõe suas definições e a cosmovisão 'oficial'."

A exclusão, portanto, produz uma inversão ideológica, que tanto lhe é útil para ampliar as fronteiras entre as classes sociais, fazendo dos ricos mais ricos e dos pobres mais pobres, quanto para ampliar a condição social de distanciamento social que lhe dá vida. A ideologia cumpre a um só tempo as funções de estabilidade e de ampliação da exclusão social. Neste sentido, como destacou AlvinO Augusto DE SÁ ${ }^{240}$, a própria relação de exclusão é vista, com razoável tranqüilidade, como um desdobramento das escolhas equivocadas que levaram o indivíduo a delinqüir.

E nesta má escolha residiria a justa resposta da sociedade ao criminoso, inclusive sendo legítimo o estigma lançado sobre ele. Esta inversão contamina a todos os envolvidos no cenário penitenciário: os servidores penitenciários passam a procurar o lobo escondido nas vestes humanas, e os presos acabam internalizando o estigma, passando a construir seus horizontes de sentido com as imagens e perspectivas (ou falta delas) que lhes são atribuídas. E isto gradativamente faz com que as normas de uma sociedade que lhe prende o corpo e lhe

${ }^{239}$ Bitencourt. Op. cit, p. 122.

${ }^{240}$ Sá, Alvino Augusto de. GDUCC - Grupo de Diálogo Universidade, Cárcere, Sociedade: uma experiência que está dando certo. Boletim IBCCRIM, v. 198, p. 11-12, 2009. 
exclui do "banquete dos eleitos" percam sentido, ao passo que vai ficando cada vez mais frágil o sentido de sociabilidade quando ele definitivamente não é uma alternativa possível.

\begin{abstract}
"Na entrada do sec. XX temos uma ruptura epistemológica séria, dentro do Saber e chegando às bases civilizacionais como um todo. (...) Em termos mais técnicos, trata-se de um questionamento radical do positivismo e do cartesianismo. Nossa cultura - e então o direito - é bastante contaminada com estas cosmovisões. Em nome de uma pretensa objetividade factual, de uma visão positivista dos conflitos sociais como fatos simples passíveis de legislação simplificadora, temos por exemplo, sujeitos de deveres e direitos destacados de seus contextos sociais, emocionais, enfim, ambientais."241
\end{abstract}

Por isso, é necessário abrir um canal para que a sociedade, de uma forma geral, e os presos em particular, possam refletir em conjunto as condutas possíveis em torno da temática da acumulação desenfreada e do desvio, bem assim das respostas que são oferecidas a ele. Não basta impor uma readequação ética como forma de reinserção social, até porque a idéia de ética se liga à de autonomia, e não a seu oposto, a heteronomia. Ou seja, para que os atores sociais possam ser reconhecidos no real contexto em que encontram-se inseridos (ou excluídos), vistos como seres históricos e não através de simples construção abstratas e reducionistas da totalidade que é o humano.

Os valores não serão melhor aceitos se forem forjados; pelo contrário, perderão seu sentido axiológico e passarão a revestir meras receitas para uma vida empobrecida e vazia. Os valores que revestem a conduta ética de uma pessoa hão de ser fruto de experiências significativas,

\footnotetext{
${ }^{241}$ Pelizzoli, Marcelo. Fundamentos para a restauração da justiça. Resolução de conflitos, justiça restaurativa e a ética da auteridadeldiálogo. In:www.idcb.org.br/documentos/artigos040806/fundamentospararestauracaojustica.pdf acessado em 24.02.2011, p. 01.
} 
como nos fala $\mathrm{SÁ}^{242}$, a fim de que sua expressão seja decorrente de uma motivação interna, principalmente. Por isso, as propostas de ressocialização são tão carentes de eficácia. Não se pode exigir, ainda menos de forma rígida, um comportamento se não são oferecidas condições para que permitam, com autonomia, agir de modo diverso.

A sociedade espera adequação jurídica ("não cometerás crime”) do preso, mas negligencia as condições vexatórias (humanas e materiais) que oferece para que ele adote a conduta esperada; se impõe (hoje em menor escala) uma esperança, ainda que frágil, nos trabalhos de ressocialização, como se o comportamento humano fosse cambiável pela introjeção pura e simples de preceitos morais desconectados da história individual e do cenário social circundante. Nas palavras de MiguEL VALERo ${ }^{243}$, corporificadas na fala de um detento,

"É certo que os momentos vividos com grande intensidade distorciam nossa capacidade de recordar dos fatos (...). O conteúdo evocado não era semelhante ao que havia ocorrido. Não recordávamos haver firmado um acordo sobre as regras de convivência no qual depositamos alguns interesses e desejos pessoais para colaborar com o bem comum. Também havíamos perdido a memória sobre a forma como fomos ignorar essas regras do jogo social e, portanto, não podemos partilhar culpas; nunca saberemos com ciência exata porque fomos nós, justamente nós, os que tiveram de re-aprender aquilo que acreditávamos bem saber."

Ora, não é difícil compreender o fracasso das expectativas ressocializadoras. Não se ressocializa para a reintegração. Não é esta a ordem natural da convivência inter-humana. Nenhuma norma social terá sentido se o sujeito previamente não for inserido no contexto em que ela é exigida. Não se requer presença escolar de quem não é aluno, e ser tratado como tal, como aluno, é pressuposto para fazê-lo responsável. Não se impõem normas religiosas sem que o fiel esteja devidamente integrado ao grupo religioso que lhe apresenta as diretrizes.

\footnotetext{
${ }^{242}$ Idem. Ibidem.

${ }^{243}$ Idem. Ibidem, p. 119.
} 
Não se fixam regras familiares a quem é estranho à família, ou que não tenha sido previamente recebido por ela. A psicologia infantil demonstra o que a prática confirma: a criança só se desenvolverá plenamente, somente internalizará as permissões e proibições do meio, na medida de em que tais comandos fizerem sentido para ele; e esse fazer sentido aponta para a imprescindível experiência de troca, de partilha, de acolhida, de integração no seu de sua família - que, para a criança, será sua primeira experiência social.

Logo, o sentimento de pertença é anterior ao ato de imposição das normas. E a qualidade do processo de pertencimento (Reintegração Social) terá direta interferência na qualidade e voluntariedade com os comandos serão sintetizados. Há de se notar o detalhe: a ressocialização não é prévia à Reintegração, mas exatamente o contrário. É a qualidade da Reintegração, a consciência de pertencimento e aceitação a um grupo social que faz o indivíduo pautar sua conduta de tal ou qual maneira. Daí nasce uma conduta autônoma, emancipada, motivada pelo sentido que o sujeito empresta a sua ação em contato com a ação dos demais: nasce então uma inter-ação.

Voltando à criança, ela não adota as regras antes de se sentir acolhida. O sentimento de confiabilidade, sobretudo no lar, faz com que as crianças encontrem sentido para as proibições e também para as permissões, sentidos que, num primeiro momento, transcendem a elas próprias, mas encontram na simbiose entre os viventes a sensibilidade de con-viver.

Todos, em menor ou maior grau, foram apresentados aos processos de aprendizagem de normas sociais. Ninguém esteve totalmente privado destas experiências, ainda que a infância tenha sido um período traumático, marcado por relações humanas frágeis e inconsistentes. Ainda assim, mesmo que por um diminuto período, os homens gozaram da satisfação de se sentirem acolhidos e, certamente, esta sensação foi determinante para a construção da autonomia perante as normas e perante a si mesmo. 
De tudo isso resta a conclusão: a Reintegração enquanto experiência significativamente humana, de diálogo e de transcendência, deve ser prévia; a ressocialização, entendida como internalização de regras, representaria uma tarefa posterior, mediada não pela tradicional sujeição, mas por uma vocação reflexiva capaz de discutir as normas, a revê-las e adaptá-las a cada contexto, antes de propriamente forjá-las. "Busca-se, na reintegração social, desenvolver um significativo diálogo entre partes que, tendo tido até então uma relação antagônica, comportam-se agora como iguais, numa relação simétrica, ainda que não se pretenda esconder hipocritamente as diferenças reais e objetivas." ${ }^{244}$

Quando a sociedade se utiliza da prisão está transparecendo que ela mesma é, em algum lugar de si, prisão para alguns de seus membros. As prisões encarceram, regra geral, os marginalizados, os excluídos que não possuem lugar social legalmente habitável. Ao mesmo tempo, porém, os cárceres encarceram a todos os que estão (ao menos temporariamente) fora de seus padrões preferenciais de clientela; e faz isso dentro dos muros de uma acusação incômoda do fracasso social de todos, "pois a marginalização, como toda 'margem', é sempre recíproca, tal como a distância, por definição." 245

Tomando de empréstimo a análise realizada por Z. FreuD ${ }^{246}$ em $O$ Mal Estar da Civilização, pode-se chegar ao ponto de concluir que a civilização exige da parte de todos os seus membros renúncias e privações ao prazer. A civilização - que não passa de um constructo

\footnotetext{
${ }^{244}$ Sá. Idem.

${ }^{245}$ Perez. Op. cit, p. 152. "Isto é, o cárcere somente destrói os destruídos, somente arruína os arruinados, somente empobrece os radicalmente empobrecidos somente marginaliza, em realidade e profundidade, aos marginalizados previamente dos processos de humanização, processo este que pode reproduzir no cárcere (com mais força e nitidez) o que já ocorria antes dele, na rua (porque o olho humano não enxerga fora o antes não tinha dentro...)" (Perez, p. 154)

${ }^{246}$ Apud. Sá. Ponderações. p. 142. Complementa o autor, no mesmo trabalho, dizendo que "o caminho do crime é o caminho daqueles a quem não foi dado o direito de participar da 'assembléia dos homens', de se 'apossar interiormente' de suas normas e, portanto, de se fortalecer perante elas, ficando então sujeitos ao jugo dessas normas e, em função disso, vulneráveis às mesmas, restando-lhes unicamente, como consolo, a ilusão de que um dia participarão da mesa farta de seus senhores." (Sá. p. 153)
} 
regulatório ou lugar ideal delineado por valores mais ou menos comuns, ou por regras do jogo mais ou menos aceitas pela maioria de seus membros reais - impõe uma distribuição desigual de privações e, sobretudo, do seu contrário, que são os prazeres.

Poucos, e é possível aqui utilizar a expressão “uma minoria de privilegiados pelo capital”, terá condição de gozar de um nível tal de prazeres que, para eles, a civilização de fato valha a pena. Ao usufruir dos benefícios do dinheiro, da terra, do saber e da cultura, esta pequena parcela suprime os sofrimentos e potencializa os aspectos mais satisfatórios da vida. A eles, portanto, a civilização é tão graciosa que deve permanecer como está, independentemente dos custos que tal permanência desequilibrada irá impor à maioria. E este quadro de desprazer intenso perante os estruturados pelas benesses fragiliza os primeiros e potencializa os segundos.

A grande probabilidade de se tornar um destinatário de sanções estigmatizantes aparece intimamente relacionada à pertença a classes sociais mais humildes financeiramente (subproletariado e grupos marginalizados). A precariedade frente ao mercado de trabalho, como a falta de qualificação profissional, as dificuldades de socialização familiar e escolar, enfim, estes e outros fatores muito mais comuns a pessoas de baixa renda do que aos de maior poder aquisitivo, se apresentam como causas da criminalidade, revelam o poder dos estigmas enquanto marcas distintivas dos menos possuídos ${ }^{247}$.

E aí surge a questão. Como tencionar a aplicação do conceito de Reintegração Social, sabendo que em geral se trata de um preso anteriormente alijado de sua subjetividade, isto é, de um indivíduo perversamente integrado antes do encarceramento e desintegrado em razão deste evento? Deixar de lado uma reflexão desta natureza representa uma escolha tendente a mascarar a realidade e, com isso, a laborar em prol da manutenção das circunstâncias tais como estão.

247 Baratta, Observaciones..., p. 364. 
Pretender edificar uma política de Reintegração Social exige, em contrapartida, o questionamento das condições sociais, das relações de exclusão. De nada adiantaria erradicar, ainda que utopicamente, a exclusão no cárcere se, ao cruzar as portas de ferro em direção à liberdade, o recluso se visse novamente alijado e estigmatizado pela sociedade. Uma visão romântica talvez se contentasse em propor, tão somente, a melhoria das condições de vida no cárcere, mas eles não corresponderiam à totalidade ou a pelo menos grande parte da dimensão da exclusão.

É, portanto, valiosa a contribuição realista de ZAFFARONI por meio da denominada clínica da vulnerabilidade. Com ela o autor inicia uma marcha para demonstrar que as pessoas não são iguais, que o mito da equidade deve descer do alto de sua abstração para pousar na materialidade da vida, nos sofrimentos humanos. No exemplo de E. RAúl ZAFFARONI ${ }^{248}$, "uma pessoa cujas características pessoais coincidem com as do estereótipo criminal, basta que incorra em um injusto leve para que se vulnerabilize."

Estes rostos que padecem antes e durante o encarceramento são a imagem de uma vida arruinada e, por isso, carecem de um projeto de revigoramento humano; isso passa pela reflexão e reconhecimento de que os sofrimentos lhes foram impostos em sociedade, o alijamento igualmente, e haverá de ser na arena social, no inter-jogo social, que estes indivíduos vulnerabilizados hão de encontrar a força necessária para se reerguer das chagas do corpo e da alma. Mas, em geral, o que eles encontram é uma ampliação do deterioramento sofrido:

"Esta comprovação com base em muitos criminalizados
latinoamericanos de classes
subalternas ou

${ }^{248}$ Zaffaroni, Eugênio Raúl. Hacia um realismo jurídico penal marginal. Caracas: Monte Avila, 1992, p.111. 
economicamente, longe de mostrar que essas características são 'causas' do delito, estão demonstrando que são 'causas' da criminalização individual e da qual o próprio sistema penal se encarrega de acentuá-las, quando não de criá-las. (...). Nada de estranho há na desnutrição da mãe durante a gestação, na subalimentação durante os primeiros anos de vida, moradias superlotadas com todas as suas sequelas, infecções, má ou nenhuma assistência sanitária, as intoxicações precoces do meio ambiente dos subúrbios das grandes cidades, a escolaridade incompleta ou inexistente, a inadaptação escolar, o padecimento da violência e a necessidade prematura dela ou da astúcia como únicos mecanismos de sobrevivência, a institucionalização prematura, o abandono em sentido psicológico com sua seqüela de insegurança, a discriminação laboral e escolar, o estigma das primeiras criminalizações ou institucionalizações sem motivo real, a ação despersonalizante das instituições totais, a lesão a autoestima provocada por vexames e torturas, configuram um quadro que, com demasiada frequencia, se apresenta uma pessoa necessitada e carente, que, não obstante continue a dramatizar suas necessidades como forma de obter melhoras circunstanciais, não obtém, todavia, uma real compreensão das mesmas, sendo este fenômeno mais freqüente e agudo quanto maior é o deterioramento sofrido." 249

Neste exato contexto, o objetivo da inclusão social deve ser, nas palavras de ZAFFARONI ${ }^{250}$, que o preso "tome consciência do papel que o poder punitivo lhe atribui, não se submeta à seleção criminalizante, assumindo voluntariamente a função, ou seja, que deixe de mostrar

249 Zaffaroni, Eugenio Raúl. Criminologia: aproximación desde um margen. Volume I. Bogotá: Temis, 1988, p.25.

250 Apud. Wolff, Maria Palma. Prisões e participação social. In. Segurança pública: uma abordagem sobre o sistema prisional. Relatório do Seminário Radiografia do Sistema Prisional: Perspectivas e Desafios. Porto Alegre, 2008, p. 81 . 
seu rosto ao sistema". Para MARIA PALMA WOLLF ${ }^{251}$, ainda no contexto dos horizontes e implicações da participação da sociedade no cenário penitenciário, a inclusão do sujeito segregado não pode ser avaliada apenas no seu aspecto material, mas deve, antes disso, ser uma possibilidade de crescimento individual e de consolidação de um projeto de vida.

A Reintegração Social, portanto, não abdica das discussões mais amplas a respeito do formato adotado pela sociedade, da exclusão que ela promove e da criminalidade que tende a engendrar. Os elementos não são determinantes uns dos outros, mas representam importantes vetores de compreensão possíveis. Não há legitimidade alguma em propor um diálogo com o encarcerado sem que a ele seja permitida a crítica à sociedade ao lado do estímulo à crítica (reflexão) de sua própria autonomia, da mesma forma que a sociedade não poderá integrar o diálogo se não puder criticar o encarcerado e ter a liberdade e o estímulo de rever as suas práticas e modos de vida.

A função de Reintegração Social, que demanda uma nova postura semântica, de início, e uma reorientação programática e operacional, na sequência, consiste na proposta de oportunizar, por meio do desenvolvimento de uma consciência crítica e autônoma, uma postura diversa da reação individual que em geral se expressa pela linguagem do crime.

Superando esta atitude isolada, o indivíduo deverá, junto aos seus companheiros de classe social, participar de suas lutas e movimentos sociais, tanto dentro quanto fora do cárcere, possibilitando a edificação de uma relação com a sociedade diversa da infração individual, mais afeita, portanto, à instauração de uma mudança social. "A anamnese social da infração e/ou do castigo-sofrimento se transforma de tal modo, para o detento, em ocasião para desenvolver o saber e a atitude que promovem a reintegração social." ${ }^{, 252}$

${ }^{251}$ Idem. Ibidem.

${ }^{252}$ Baratta, Alessandro. Reintegrazione sociale. Ridefinizione Del concetto ed elementi di operazionalizzazione. Dei Delitti e Delle Pene: Rivista de Studi Sociali, Storici e Giuridici Sulla Questione Criminale. n. 3, 1994/1996, 
É dizer: a Reintegração se consubstancia num processo, logo, numa proposta de meio, preocupada em possibilitar no presente a reaquisição do diálogo outrora desequilibrado em razão da prática criminosa (ou mesmo antes dela), e esta perspectiva, ao contrário, exige autonomia ética e voluntariedade de todos os atores: encarcerados e sociedade. É imperioso afirmar, desde já, que o crime não será considerado apenas numa perspectiva individual, mas, sobretudo como uma questão social, e que como tal exige uma mudança de postura de todos, em especial da própria sociedade, com o escopo de readquirir o equilíbrio para o exercício do diálogo.

O processo de tomada de consciência dos atores que gravitam em torno da realidade penitenciária deve se espraiar para fora do cárcere, chegando à arena do debate público a fim de possibilitar que também a sociedade possa se identificar com o preso, tal qual se espera que o preso se identifique com a sociedade.

A Reintegração Social não deve significar uma simples pretensão de mudança do comportamento e transformação na atitude do encarcerado, mas deve mirar finalidades que vão além do indivíduo e ser capaz de transformar a discussão em torno da questão

p. 148. Trata-se de um trabalho mais abrangente de Baratta, no qual ele inicia analisando o quadro mais abrangente das teorias da pena, propondo a distinção entre dois grupos: as teorias ideológicas e as teorias tecnológicas. O primeiro grupo seria composto pelas teorias da prevenção geral negativa (intimidação) e prevenção especial positiva (ressocialização); o segundo grupo abrangeria as teorias da prevenção especial negativa (neutralização e intimidação específica) e prevenção geral positiva (prevenção-integração). - Baratta, Reintegrazione , p.137-139. Versões iniciais deste trabalho foram publicadas em língua espanhola sob títulos os títulos Por un concepto critico de reintegracíon social del condenado (In. Oliveira, E. (Coord.). Criminologia crítica (Fórum Internacional de Criminologia Crítica). Belém: CEJUP, 1990) e Resocialización o control social. Por un concepto crítico de "reintegración social" del condenado (Criminología y Derecho Penal. año I, n. 1, enero/junio, 1991, Guayaquil, Ecuador). Este material foi vertido para o português sob o título Ressocialização ou controle social. Uma abordagem crítica da "reintegração social" do sentenciado (In. <http://www.eap.sp.gov.br/pdf/ressocializacao.pdf> Acessado em 24.02.2011). Importa registrar que os trabalhos originalmente publicados em língua espanhola não são idênticos àquele publicado na Itália quase quatro anos após as primeiras versões. Subsistiu neste último material a estrutura de "operacionalização" (propostas de intervenção de caráter reintegradoras) dos trabalhos anteriores, sendo nova a parte introdutória onde o autor avança mais na discussão dos fins da pena em cotejo com a proposta da reintegração social. 
penitenciária numa oportunidade de aprendizado e tomada de consciência política sobre o plano mais amplo dos conflitos sociais.

Por fim, quadra ressaltar a observação feita por WOLFF $^{253}$ acerca da importância da participação social no contexto da gestão de políticas públicas. Segundo a autora, é preciso se ter a exata noção de que a integração da sociedade nos assuntos propriamente administrativos responde a duas questões: a primeira se liga ao sucateamente do Estado enquanto gestor público e a sua participação cada vez mais reduzida na sociedade; neste quadro de inoperância, a sociedade assumiria o protagonismo por gerir os quinhões de poder de modo a suprir a ausência de ações concretas do ente estatal.

Outra forma de conceber tal participação é vê-la além da idéia de substituição gerencial, para alicerçar uma proposta de participação complementar e construção de uma hegemonia política, ou seja, de um empoderamento da questão política por parte da sociedade. É nesta esfera que se compreende o conceito de Reintegração Social aqui edificado. Não se quer com ele, em definitvo, suprimir o Estado, pois não se trata de forjar um projeto político de índole anarquista sob a retórica de estar prestando mecanismos de aproximação entre os homens. Não pode ser esta a proposta final da Reintegração Social, ainda que igualmente não seja possível negá-la, na hipótese de a emancipação inter-humana se encaminhar por estas sendas políticas.

Mas, e isto é valioso, não há como subsistir nenhuma idéia de Reintegração Social orientada por uma meta apriorística ao contato entre seus atores. Isto seria um exercício de confirmação de premissas externas à experiência humana, em si. $\mathrm{O}$ que não quer dizer que se possam escolhidas, até mesmo para a boa práxis do diálogo, algumas diretrizes possíveis de se valerem como limites deste inter-jogo humano. De fato, as Ações de Promoção do Interhumano complementam a atuação do Estado e podem, eventualmente, se direcionar in loco

${ }^{253}$ Wolff. Op., cit, p. 82. 
para sua gradativa substituição. Mas tal efeito não pode ser um móvel da Ação, senão que uma consequência dela - e que dado o seu caráter de interesse geral, há de ser reavaliada pela esfera do Inter-humano coletivo.

\subsection{Fundamentação filosófica da Reintegração Social: O HOMEM E A INTER- HUMANIDADE}

\subsubsection{Quem é o homem para a Reintegração Social?}

$\mathrm{Na}$ base de qualquer intervenção teórica afeita ao campo penitenciário há uma visão de homem que orienta os rumos da investigação. Com isto não se está afirmando que uma dada concepção assumida pelo investigador venha a invalidar sua empreitada; pelo contrário, seria a ausência de uma tal diretiva que faria isso. Ocorre que, não raro, muito se fala sobre o homem, sobre suas ações tanto no plano individual quanto na esfera coletiva, sem que com isso reste clara a orientação filosófica que está na base deste homem abstrato.

E uma boa teoria deve deixar isso claro, até mesmo para que se saiba, de antemão, se o sujeito, que circunstancialmente é um objeto de estudo, está circunscrito aos limites da própria teoria ou se, pelo contrário, é a teoria que estará à disposição das reinvenções humanas; ou o homem é apreendido abstratamente e ali fica eclipsado, ou é apreendido apenas na medida do que se sabe ate ali, sem que se possa afirmar categoricamente ser este quadro um dado pronto e acabado; ou a proposta se reveste de uma fotografia, cuja interpretação só ganha vida na medida em que é manuseada e manipulada pelo próprio intérprete, ou então assume, à semelhança de um filme, que a dinâmica não cessa e está sempre pronta a se mostrar de forma inesperada.

Além de não haver um posicionamento filosófico de base acerca da natureza e das possibilidades do objeto de estudo com que se trabalha, também há um ceticismo, uma 
desesperança para com o homem; quadro que é um misto de criador e criatura, pois se de um lado a teoria se apresenta como um tributo da história ("o homem é assim, a sociedade é assim, logo o convívio humano há de ser assim.”), de outro é ela mesma quem faz a história ao orientar as práticas humanas. É, portanto, a opção que se tem entre olhar para trás ou para frente, desconsiderando a presentificação que há entre estas duas possibilidades.

A tarefa que se empreenderá, nesta linha, será a de apresentar o substrato filosófico do homem que o conceito de Reintegração Social ora apresentado considera como objeto do estudo, mas como sujeito de sua existência e colaborador da existência alheia. E, para tanto, quadra deixar registrado que a opção aqui assumida será pela idéia, que se mostra de todo coerente com a proposta reintegradora, que JEAN-JACQUES ROUSSEAU deixou registrada na história da filosofia: a idéia da benignidade humana original.

Foi a caminho da prisão (para coincidência deste estudo), a fim de encontrar o amigo e também conhecido filósofo DENIS DiDEROT que RousSEAU teve um brilhante "êxtase emocional" 254 que o levaria a ser reconhecido com um dos mais brilhantes filósofos de sua época. Na Carta a Malesherbes, de 12 de janeiro de 1762, narra esta súbita iluminação:

"Eu estava indo ao encontro de Diderot, então prisioneiro à Vincennes; tinha no meu bolso o jornal Mercure de France e eu o folhei ao longo do caminho. Deparei-me com a questão da Academia de Dijon que deu lugar ao meu primeiro escrito. Inspiração súbita, eis o movimento que se fez em mim enquanto lia; de repente eu senti o meu espírito deslumbrar-se com mil luzes; uma multidão de idéias vivas aí se apresentaram com uma força e uma confusão tais que me lançaram em uma confusão inexpremível; eu senti a minha cabeça tomada por um

${ }^{254}$ Campos, Edemilson Antunes de. A tirania de narciso: alteridade, narcisismo e politica. São Paulo: Annablume/Fapesp, 2001, p. 34. 
atordoado semelhante à embriaguez. Uma violenta palpitação me oprime; excita meu peito, não podendo mais respirar caminhando, eu me deixo cair sob uma das árvores da alameda e aí passo uma meia hora em uma tal agitação que quando dela saí tinha minhas vestes molhadas de lágrimas sem ter sentido que as derramava. Oh! Monsier se eu pudesse ter escrito um quarto do que eu vivi e senti sob aquela árvore...com que claridade eu teria feito emergir todas as contradições do distema social, com que força eu teria exposto os abusos de nossas instituições, com que simplicidade eu teria demonstrado que o homem é bom naturalmente e que é em função das instituições que os homens se tornam maus. (...),255

A grande sensibilidade de ROUSSEAU ocorreu no sentido de visualizar na constituição originária do homem uma oposição secreta entre o ser-do-homem e o parecer; ou seja, o homem enquanto tal era de natureza essencialmente boa e é no curso de sua vida que esta base vai se degradando. Pode-se dizer que o homem rousseauniano é concebido com na base esperança, na bondade de coração que singularizaria a todos, mas seria submetido a uma exposição degradante do mundo exterior, das imposições culturais.

“A sociedade é responsável pelos males. É ela que faz do homem um tirano da natureza e de si mesmo." 256 O homem é de boa índole, mas se desvia em razão das demandas socializadoras que exigem uma adaptação e, com isso, impõem uma cisão entre o ser do homem e o parecer enquanto atributo de inserção social. A origem do mal, neste horizonte, repousaria na fissura entre o ser e o parecer ${ }^{257}$.

255 Apud. Campos. Op. cit, p. 34-35.

${ }^{256}$ Idem. Ibidem, p. 45.

257 Idem. p. 37. 
De acordo com a interpretação do filósofo JEAN STAROBISNKI ${ }^{258}$, a obra de ROUSSEAU teve fundamental importância na reconstrução da unidade humana perdida (sobretudo em razão das concepções fragmentárias impostas ao homem, orientadas pelo cartesianismo e, mais à frente, pelo positivismo), e neste sentido o autor propõe identificar na interioridade, no recolhimento e na retidão, as formas de que o homem escape de sua experiência de violência e retorno ao seio de uma essência edificante.

A proposta de STAROBINSKY propõe uma forma de escapismo, de fuga da sociedade para dentro de si; não uma fuga física, mas uma oportunidade para o homem se refugiar em sua interioridade, nos recôndidos ainda não contaminados e corrompidos pela sociedade. "O mal é véu e velamento, é máscara, tem acordo com o factício, e não existiria se o homem não tivesse a perigosa liberdade de negar, pelo artifício, o dado natural. É entre as mãos do homem e não em seu coração, que tudo degenera.",259

A introspecção proposta e que, em última instância, levaria o homem a um reencontro com o seu "eu" mais puro, necessitaria da parte do sujeito uma negação à ordem social aviltante em privilégio da ordem natural esclarecedora.

No seu estado de natureza (que é inerente ao homem e não mero evento transitório), portanto, as paixões humanas gravitam em torno de dois sentidos: o amor-de-si e a pitié. O primeiro, como dizia Rousseau, se referia a um desejo de autoconservação, não excludente e que se compatibilizava com o desejo dos demais; a pitié, por sua vez, trazia a idéia de uma piedade natural enquanto atributo da capacidade humana de se identificar com o sofrimento alheio. Dessa forma, amor-de-si e pitié formavam dois horizontes da bondade humana: um voltado para a interioridade e outro para a exterioridade ${ }^{260}$.

${ }^{258}$ Idem. p. 48.

${ }^{259}$ Starobinsky, Apud. Campos, p. 48.

${ }^{260}$ Campos. Op. cit, p. 52. 
Como destaca EDEMILSON CAMPOS, a pitié representa um sentimento que liga um indivíduo a outro, colocando-o imageticamente no lugar de quem sofre, sem que com isso ele seja despojado de seu próprio lugar na Ordem. Trata-se de um "movimento de transporte" que pressupõe uma solidariedade imanente, própria da natureza humana, enquanto partilha dos dissabores experienciados pelos outros. Assim, a dor seria arrefecida enquanto era repartida entre todos; a existência, seria, assim, menos dolorosa na medida em que favorecesse um paradigma social de "caminhar com"; a solidão teria um espaço reduzido, apenas se referindo a oportunidade de que cada um tenha na sua interioridade um contato próprio com a unidade a partir do eu.

Esta circunstancia de ser um e outro, concomitantemente, denota a visão que ROUSSEAU demonstrava acerca da alteridade, do outro enquanto parte de si mesmo e que, por isso, seria um misto de outros: o outro é ele, e portanto outro para mim, mas é também parte de mim, e portanto outro para ele mesmo.

"Colocar-se no lugar do outro: esta é, sem dúvida, a característica essencial dessa capacidade de identificação com um outro eu, e sobre o qual se funda a possibilidade de toda 'relação' com o outro, ou seja, tanto a possibilidade de qualquer comércio quanto a possibilidade de qualquer espetáculo."261

A pitié, que pode ser interpretada como fundamento da consciência moral rousseauniana, também pode se perverter. E isso ocorreria quando o amor-próprio (ensimesmamento narcísico) superasse a esfera da solidariedade. "Com efeito, o homem social, ao invés de se identificar empaticamente com o outro, visa, no limite, suprimir a alteridade."262 As relações

${ }^{261}$ Rousseau. Apud. Campos, p. 53.

${ }^{262}$ Campos. Op. cit, p. 54. 
sociais potencializam as condições necessárias para a emergência do amor-próprio (narcisista) em detrimento dos sentimentos altruístas.

É muito mais aceito na sociedade contemporânea aquele que se mostra competitivo, mais sábio, mais belo, mais eficaz, mais rentável... a lógica do mais gera, por consequiência, a atribuição do rótulo de "menos" a outros, e tais parâmetros acabam por intensificar as diferenças e obscurecer os diversos pontos de semelhança entre os homens. Neste cenário, vale mais o foco no eu do que no nós; o homem autocentrado acaba se barbarizando, como brilhantemente destacou ORTEGA Y GASSET, quando afirmava que a especialização barbarizava o homem ao lhe subtrair os sentidos da totalidade, e barbarizado ele se torna incapaz de ver tanto o sofrimento que impõe a si como a dor que transfere aos demais semelhantes - que passam a ser vistos como opositores na roda viva da existência.

O "movimento de transporte" promovido pela pitié não se perde neste cenário. O homem continua se transportando aos demais; contudo, à diferença da idéia original, não o faz imbuído de sentimento altruísta, mas, opostamente, vai ao outro para se comparar e subtrair dele o que houver de interessante, para logo em seguida retornar ao seu plano narcísico.

A este estágio CAMPOS denomina de "perversão da pitiée"263, ou seja, o processo que possibilita a trajetória em que o amor-de-si primitivo é corrompido pelo amor-próprio. Ainda aqui, o homem encarnado em si não prescinde do outro, ainda que apenas dele necessite para que lhe sirva de referencial comparativo, ou seja, é indispensável para o amor-próprio na sua extrema carência a presença de alguém para prestar-lhe o reforço de suas escolhas e de sua maneira de ser, ou de impor mudanças a elas.

${ }^{263}$ Campos. Op. cit, p. 84. 
A lógica narcísica acarreta um vampirismo social, na medida em que impõe a incessante necessidade de que a vitalidade alheia (que pode ser metaforicamente comparada ao sangue humano) seja consumida, dada a insuficiência e o isolamento que o amor-próprio impõe. Este quadro tende a gerar uma alienação no homem, pois ele deixa de identificar-se na sua autonomia, ao mesmo tempo em que não identifica os demais como sujeitos de autonomia. Há, por assim dizer, um processo de objetificação coletiva: todos são reconhecidos apenas na simbiose com a coletividade, e tanto o que olha quanto aqueles a quem se dirige o olhar passam a abstrair o ser em detrimento do parecer.

E isso porque o olhar e o que é olhado passaram pela experiência da perversão e passaram a se pautar, mutuamente, por algo que lhes é externo: estima, prestígio e a vitalidade alheia. "A exemplo da pitié, o amor-próprio também é suscetível de se refinar e de se intensificar. Levado às últimas conseqüências transforma-se em uma espécie bem precisa de loucura, ou seja, converte-se em furor de se distinguir."264 O homem guiado por estes sentimentos se transforma num protótipo de invejoso, e está a todo momento buscando no exterior a peça que falta para se completar; está naturalmente carente de sentido e distante do cosmos, na medida em que o sentido e o cosmos somente lhes são familiares quando estabelece laços de fraternidade, ou seja, volta os olhos para o que está originalmente dentro dele e não fora, pauta-se pelo amor-de-si e pela pitié.

Esta imposição da vontade de uns sobre a dos demais, tolhendo-lhes a autonomia e promovendo o sobrepujamento como única norma de conduta válida acarreta uma devassidão entre as fronteiras do espaço público e do privado, e aquele é suprimido em prol deste. E assim, o ser narcísico consuma o seu jugo.

"Narciso é cada um dos tiranos que - no fim da história - nos habita. Narcisos são aqueles cujos 'transportes imaginários' ocultam o outro- velado ou não! O ideal da Aufklärung - a

${ }^{264}$ Campos. Op. cit, p. 86. 
denúncia, a retirada do véu - tem para ROUSSEAU um papel secundário. O véu é só suporte de ‘transportes imaginarios'. Estes só são possíveis onde a fissura entre o ser e o parecer se impôs. Nenhum tirano se manteria no poder, por um instante sequer, na ausência desses 'transportes' - frutos de um viver intenso do aparecer social. De fato, como expõe RoUSSEAU, nenhum tirano poderia usurpar um poder ilegítimo sem a cumplicidade dos súditos." 265

A tendência tão em voga nos dias de hoje de viver em função das impressões causadas por alguns poucos, ou seja, viver de fora para dentro, viver a experiência narcísica de uns como padrão de conduta, em detrimento da vida pautada pelas experiências do próprio ser (de dentro para fora), não sintetiza uma condição natural, mas sim cultural, e tem sua origem no avesso da relação inter-humana, na sua negação, pois se desdobra na dependência de uns perante outros.

Em nada auxilia, por conseguinte, opor ao narcisismo imperante uma proposta de índole puramente coletiva, gregária. Como destaca M. BUBER ${ }^{266}$, enquanto o individualismo concebe o homem encerrado a uma relação ensimesmada, o coletivismo tende a invisibilizar este mesmo homem, apenas se preocupando com a sociedade da qual ele faz parte. Assim, nada de construtivo para a compreensão humana pode emergir destes extremos, que de um lado potencializam o singular em detrimento do plural e, de outro, fazem exatamente o sentido inverso, mas nas duas vias se observa a redução de um campo em sacrifício de outro.

Por isso, BubER entende que o conhecimento do homem virá do próprio homem, mas não como decorrência de suas vivências ensimesmadas ou subtraídas pelo coletivo. A experiência que marca a essência humana e que informa um sentido sobre ele há de se caracterizada por um inevitável encontro do indivíduo com seus semelhantes, sem que ele se perca neste trajeto em uma expansão ou uma redução de si, pois somente com o reconhecimento do outro pelo

\footnotetext{
${ }^{265}$ Campos, p. 89.

266 Buber, Martin. Qué es el hombre. Breviarios del Fondo de Cultura Económica. Madrid: Ediciones F.C.E España, 1949, p. 142.
} 
próprio homem, identificando neste contato os pontos comuns e aqueles singulares, se poderá caminhar para um cenário de relações humanas construtivamente transformadoras ${ }^{267}$.

Portanto, o fundamental da existência humana não é nem o indivíduo enquanto tal nem a coletividade enquanto tal, mas é o homem com o próprio homem, "outramente". "O que singulariza o mundo humano é, acima de tudo, que nele ocorre entre os seres algo não encontrado em nenhum rincão da natureza." 268 A medida deste contato centrado ora no indivíduo, ora no exterior, importa a reflexão acerca da tensão entre ser e parecer, sobretudo para não se cair nos excessos de um de outro, que levam acarretam as dicotomias alegadas por Buber.

A aparência surge como uma estratégia fácil de aceite social, mas que furta do homem o seu bem mais íntimo: a subjetividade. Esta luta para superar as aparências, para manter-se fiel a sua história e a quem ele realmente é se trata de um ato de coragem, como prenuncia Martin Buber $^{269}$, e a batalha em prol de sua subjetividade exige um grau elevado de doação, "mas o preço pago nunca é demasiadamente alto" para que se possa abrir mão de Ser.

Na linha de M. BuBER ${ }^{270}$ é possível distinguir duas formas de existência humana: a primeira ligada ao sentido de ser, isto é, de uma vida real, que é; a segunda, ligada à idéia de parecer, assim entendida como uma existência imagética, ideal. As duas formas aparecem normalmente imbricadas, sendo difícil apontar um exemplo de homem completamente alheio às impressões deixadas nos outros, ou outro que tenha se guiado por completo através de tais percepções artificiais, sem que tenha com isso provocado um adoecimento de seu eu. Portanto, a maioria dos homens vive nesta zona de convergência entre o ser e o parecer,

\footnotetext{
${ }^{267}$ Buber, Op. cit, p. 144-145.

${ }^{268}$ Idem. p. 146.

${ }^{269}$ Buber, Martin. Do diálogo e do dialógico. Trad. Maria Ekstein de Souza Queiroz e Regina Weinberg. São Paulo: Perspectiva, 2007, p. 144.

${ }^{270}$ Buber. Op. cit, p. 141-142.
} 
havendo alguns cujo comportamento essencial predomina uma ou outra espécie. Um contexto prático é apresentado por BUBER ${ }^{271}$ :

"Tomemos como exemplo mais simples e contudo bastante nítido de uma situação em que duas pessoas olham uma para a outra, uma pessoa pertencendo ao tipo básico da primeira espécie e a outra da segunda. O homem que vive conforme o seu ser olha para o outro precisamente como se olha para alguém com quem se mantém relações pessoais; é um olhar 'espontâneo', 'sem reservas'; é verdade que, naturalmente, ele não deixa de ser influenciado pela intenção de fazer-se compreender pelo outro, mas não é influenciado por qualquer pensamento sobre a imagem que pode ou deve desperta no outro, quanto à sua própria natureza. É diferente com o seu posto: já que para ele o que importa é a imagem que sua aparência produz no outro, isto é, o componente mais 'expressivo' desta aparência, o seu olhar, ele 'faz' este olhar; com a ajuda da capacidade que o homem possui em maior ou menor medida de fazer aparecer um elemento determinado do Ser no olhar, ele fabrica um olhar que deve atuar como uma manifestação espontânea e, com bastante freqüência, assim atua; e não somente como manifestação do acontecimento psíquico que supostamente se dá neste momento, mas também ao mesmo tempo como a reflexão de um ser pessoal de tal ou tal natureza."

Neste cenário de compreensão do homem, a civilização também representa um freio à espontaneidade, ao exercício do amor-de-si, e assim favorece muito mais a aparência que corresponde aos padrões narcísicos. O processo civilizatório que culminou com a criação do espaço público foi edificado sob um solo de ilusões. As boas maneiras, as relações impostas

${ }^{271}$ Buber. Op. cit, p. 142. 
sob o rótulo de "urbanidade", a polidez, o prestígio, a estima pública, a honradez perante os demais muito mais válida do que perante si mesmo, enfim, os hábitos determinantes para uma boa reputação social foram superando a importância da própria raiz humana tomada em seu sentido de singularidade.

A standardização do homem foi reduzindo seu horizonte privado original, e o que restou dele se transformou numa imagem refletida das exigências externas. "A vida social se teatraliza, estabelecendo uma cisão definitiva entre o ser e o parecer."272

A civilidade passou, sobretudo em grandes centros sociais, a ser aferida pela hetero-atribuição de valor, e quanto mais "votos" se tem nesta contagem, melhor inserida é a pessoa. Esta hetero-atribuição tem, em última análise, o papel de retirar o valor intrínseco do indivíduo para fixar sua validade social na imagem que os demais lhe imputam, lembrando que esta imputação não será adquirida sem dores, sem amesquinhamento e sem uma árdua competição. Todos estão, nesta subversão do valor humano, buscando uma constante superação do outro, ainda que deles dependam exatamente para se prestarem como parâmatros do sucesso ou da desgraça própria.

E assim, se a idéia de sucesso - especialmente ligada a conquistas materiais - passa a ser concebida como um atributo típico de pessoas vitoriosas, qualificadas, ao passo que a derrota (que deve ser interpretada em cada época de acordo com as valias que a civilização lhe atribui) viria como um desdobramento do fracasso próprio, da inaptidão para competir em igualdade com os bem-aventurados - certo que, em graus; e aí, se estabelece a fragilidade significativamente humana advinda destas premissas e deste tipo de comparação.

${ }^{272}$ Campos. Op. cit, p. 106. 
Tudo, portanto, é lido sob a lente do amor-próprio, seja a vitória, seja a derrota. Segundo SENNETT $^{273}$, o mito do narciso significa auto-absorção, circunstância que impede o conhecimento de outras realidades que não a própria, e isso acaba por destruir em máxima potência o próprio detentor do amor-próprio como referencial devido; mas o mito também remete ao fato de que o Ser-Narciso ao se ver espelhado na superfície da água não se dá conta de que a água é uma coisa diversa dele, que se encontra fora dele, e assim ele acaba se tornando cego a suas próprias limitações.

Isso faz com o narcicismo se retro-alimente até que esta hospedagem possa ser provocada; o que somente será possível à medida que o amor-de-si e pitié possam reocupar os seus espaços no comportamento humano.

Se o amor-próprio, que, em matéria criminal, remete aos discursos mais empedrecidos e odiosos quanto à possibilidade de aproximação entre os interlocutores do contexto criminal, remete também ao que D. GARLAND denominava de protagonismo da vítima - que não deixa de ser uma forma de reduzir a complexidade do cenário relacional, do qual a vítima é um dos integrantes -, desencadeou o populismo criminal e toda uma série de medidas que têm por escopo resolver o "problema" do crime sem acordo, negociações, mas de forma a privilegiar uma das vozes em detrimento de tantas outras. Ora, não é difícil constatar que o comportamento que o homem apresenta ao público e no cenário social é, naturalmente, um desdobramento do que ele tem em si ou, por outro lado, do que ele quer transparecer como próprio.

A alienação, com isso, não seria apenas uma situação de embuste, de mentira, de inverdade apresentada ao homem, mas, antes disso, teria o seu nascedouro na maior ou menor disponibilidade de este mesmo homem deixar-se levar pelo seu egoísmo (alienação de si

${ }^{273}$ Apud, Campos, p. 120. 
mesmo), pelos seus interesses, pela magia e, ao mesmo tempo, pela simplicidade de conceber o mundo enquanto obra sua.

O homem alienado de si é, assim, aquele que nega sua natureza generosa, que por vezes passa a não mais ser identificada; a autodepreciação emerge como uma resposta que, antes de negar o amor-de-si, coloca-o em relevo na medida em que todo o ser depreciado sofre com esta situação, e isto porque nenhum homem existe para ser objeto de si e dos outros. O medo, a angústia, o assombro são sensações que demarcam fronteiras que, se não existissem, seriam incapazes de gerar intraquilidades no homem.

O homem embebido em amor-próprio não enxerga o outro, mas o que vê é apenas uma projeção de si, uma distorção daquilo que está dentro dele mesmo. O monstro e os pesadelos que advêm desta figuração nascem primeiro no interior egoístico de quem sente para depois, e somente depois, buscarem um hospedeiro que os irá suportar. A vingança, a expiação da pena, a inoucuização do criminoso são mecanismos que se vingam primeiro do proponente, expiando suas incongruências e neutralizando a projeção do seu $e u$ terminantemente negado através do outro. O encarceramento atualiza este alheamento de si, do amor-de-si, e, em vez de promover a paz tão alardeada, promove a alienação de grande parte da sociedade que insiste em permanecer como uma figuração de si, e não como uma experiência propriamente do ser.

Uma tal visão de homem, que muitos reputam como "romântica", em momento algum nega a possibilidade de que ele se imponha de forma maldosa, instrumental, egoística; apenas considera que este comportamento não é a sua essência, não é o seu ser, mas uma crosta, uma aparência que se coloca em torno do verdadeiro ser humano. O homem é uma totalidade em si; comporta o universo em seu espírito, mas se vale dele e se manifesta nele conforme esteja mais estruturado em sua essência de ser ou de parecer; mais afeito ao amor-de-si ou ao amor- 
próprio. É certo que todo homem guarda em si a ambivalência do universo, os avessos da realidade e os contrários da vida.

"Não é simples admitir que há um ser maquiavélico dentro de nós, um sujeito inquieto, que se diz consciente e autônomo e livre, e que olha o mundo a partir de si como centro, e tende a desmoronar quando perde o controle da situação. Tudo deve estar em seu mundo, no seu campo de visão, e à mão; a mani-pulare. E assim, desafortunadamente, o mal está bem dentro. Quando olho o outro com os olhos do julgamento voraz, aquilo que vejo é sempre algo que já tenho em algum grau dentro de mim. Gloriosa interdependência!, que me une ainda mais com a miserabilidade que penso alheia. Felizmente, isso serve também para o bem, o bem que vejo em mim é tal presente nos outros. Admitir isso é atuar na humildade, ou seja, na terra (humus); por os pés no chão, aceitando que o outro pode ter qualidadess maiores que as minhas, e que eu possa ter hábitos perniciosos iguais ao de quem considero 'ladrão', 'prostituta', 'cafajeste' etc.,"274

Ninguém nega isso, ao passo que também não há como negar que as tradicionais estratégias de intervenção aplicadas ao cárcere - tratamento penitenciário e ressocialização - o que fizeram foi supervalorizar a crosta, a aparência, o estigma e eclipsar por completo qualquer centelha de esperança, de redescoberta e de transcendência que somente o homem é capaz de propiciar. Tais modalidades (e junto a elas todas as demais finalidades atribuídas à pena) partem de uma concepção de homem arcaico, naturalmente mal e que somente seria contido dentro dos limites da arena civilizada. Esta concepção hobbesiana da natureza humana, de

${ }^{274}$ Pelizzoli. Op. cit, p. 02 
violência estrutural e indissociabilidade não passou despercebida pela avaliação de Rousseau e de sua teoria ${ }^{275}$.

Com efeito, o próprio RoUSSEAU reconhecia que os preconceitos e a corrupção atribuídas aos homens por T. HoBBES não era outra coisa que a corrupção do amor-de-si do próprio filósofo, que passou então a esbravejar aquilo que de dentro dele emergia como uma projeção a todos distribuída. ThOmAs HoBBes, no Leviatã, propõe exatamente esta tarefa de ao seu leitor: "Lête a ti mesmo" 276 .

E essa demonstração do filósofo inglês foi suficiente para que ROUSSEAU interpretasse que ele mesmo reconheceu a importância de se encontrar a natureza humana na interioridade, mas que esta tarefa feita de forma isolada, sem a experiência do outro, da pitié, levaria indeclinavelmente a uma leitura mediada pelo amor-próprio. Daí a conclusão de RoUSSEAU: Hobbes lê a natureza humana projetada de sua própria natureza, enquanto natureza egolátrica $^{277}$.

Seguindo as trilhas deixadas por RoussEAU, é possível sem traumas e complexidades conceber o homem como um ser universal, detentor de potencias do bem e do mau; de forças centrípetas e centrífugas; de amor-de-si e de amor-próprio; de pitié e de egoísmo. A natureza bondosa não representava bondade irrestrita, senão que uma origem de bondade. Não há contradição em afirmar que o homem é bom em razão de seu tributo transcendental, mas que poderia se perder na maldade conforme orientasse sua vida neste sentido.

\footnotetext{
${ }^{275}$ Nas palavras de Rousseau (Apud. Campos, p. 69), criticando as premissas de Hobbes, se extrai o seguinte: "Não iremos, sobretudo, concluir com Hobbes que, por não ter nenhuma idéia de bondade, seja o homem naturalmente mau; que seja corrupto porque não conhece a virtude; que nem sempre recusa a seus semelhantes serviço que não crê dever-lhes; nem que, devido ao direito que se atribui com razão relativamente às coisas de que necessita, loucamente imagine ser o proprietário do universo inteiro. (...) Raciocinando sobre os princípios que estabeleceu, esse autor deveria dizer que, sendo o estado de natureza aquele no qual o cuidado de nossa conservação é o menos prejudicial ao de outrem, esse estado era, consequentemente, o mais propício à paz e o mais conveniente ao gênero humano."

${ }^{276}$ Campos. Op. cit, p. 68.

${ }^{277}$ Idem. Ibidem.
} 
Esse homem sincrético, plural, de que falava RoUSSEAU, somente pode se expressar em sua inteireza, em sua essência, na medida em que goza da experiência inter-humana, para quem o diálogo é o instrumental por excelência. Para encerrar este ponto, resta deixar uma mensagem de MARTIN BUBER ${ }^{278}$ acerca da natureza humana, muito apropriada para romper com alguns dogmas atribuídos aos presos e que acabem por impossibilitar o diálogo entre o cárcere e a sociedade.

"Não existe, entretanto, o Ser mau, não viceja ele em todo lugar? Eu nunca conheci jovem algum que me parecesse irremediavelmente mau. Certamente, torna-se cada vez mais difícil perfurar a crosta cada vez mais endurecida que se formou sobre o Ser. É assim que se origina a falsa perspectiva de uma 'natureza' imutável. Ela é falsa; a fachada é enganosa; o homem, enquanto homem, pode ser redimido."

A verdadeira missão do homem, segundo RousSEAU ${ }^{279}$, é a de zelar pela ordem do mundo, pois o homem é a única entre todas as espécies capaz de apreender a ordem do cosmo. "Portanto, é à medida que se reconhece como fazendo parte da totalidade cósmica que o homem é capaz de suavizar seu egoísmo, reconhecendo a alteridade e respeitando seu semelhante."

Neste cenário, a Reintegração Social surgiria como uma proposta apta a reapresentar ao homem a essência que ele se esqueceu que tem, ou seja, se prestaria a exercer um papel de busca do elemento eclipsado pelo narcisismo e, com o seu encontro, a busca passaria a ser do outro enquanto complemento humano indispensável na relação existencial.

\footnotetext{
${ }^{278}$ Buber, Do diálogo..., p. 144.

${ }^{279}$ Apud. Campos, p. 129.
} 


\subsubsection{O diálogo e a redescoberta do amor-de-si}

Apenas na natureza humana um ser concreto busca o outro para se comunicar com ele numa esfera comum, e este encontro produz um campo simbólico que perpassa o campo singular de cada um, mas, com eles não se identifica. É o campo que BUBER ${ }^{280}$ denomina de entre.

"Logos vem de palavra, antes que razão e calculabilidade, e é palavra dita e cambiada (dialogos). Significa que as verdades são dialeticamente produzidas e aceitas; não são universais e prontas e a-históricas, da cabeça de alguém ou de uma autoridade fora da comunidade. O homem é um ser ontologicamente de linguagem. Não é só porque fala. Mas porque se caracteriza como humano pela linguagem - entre sujeitos e com o ambiente." 281

Este plano do "entre" representa uma construção que se apropria da visão ontológica do homem concreto, mas não se detém nela, como por exemplo fazem os filósofos existencialistas. BUBER toma do homem concreto a sua realidade mais tangível (que é a capacidade dialogal) e avança para propor uma idéia que não está no homem, mas nasce no homem para alcançar um contexto que lhe é transcendente.

Neste cenário (o "entre") nem o eu de um dos interlocutores e nem o tu do outro se encontram isolados, senão que há uma fusão que dá vida à relação eu-tu. Neste sentido, o horizonte humano fornecido por BUBER não pode ser lido no singular, monologicamente, pois compreende, necessariamente, um homem dialogal, um ser que está na presença recíproca do outro; os interlocutores não são projeções ou sombras: aparecem enquanto seres de autonomia, dotados de singularidade mas que só adquirem esta identificação, este conhecimento de si, através da experiência que o outro lhe proporciona, na mesma medida em que é ele afetado e tocado pela presença de seu interlocutor. Há, portanto, uma relação de

\footnotetext{
${ }^{280}$ Buber, Que es..., p. 147.

${ }^{281}$ Pelizzoli. Op. cit, p. 05.
} 
encontro do um com o outro "entre" eles; nem acima e nem abaixo. E isso pressupõe, de antemão, a existência de um ambiente de simetria.

Não há como negar a influência da filosofia rousseauniana na obra de M. BuBER. A partir do instante em que este filósofo incorpora o homem de Rousseau, ele empresta uma nova forma de concretizar o humano, o amor-de-si de que o pensador francês falava. ROUSSEAU não deixou de compreender a essência do ser humano em sua relação de doação ao semelhante e, consequentemente, ao mundo por eles habitado. Tanto é assim que outro conceito chave está na idéia de pitié enquanto caridade e partilha de sofrimento.

Mas esta partilha não se dava à base da simples divisão dos dissabores em parcelas fragmentadas; esta tarefa exigia mais do humano: exigia dele uma disponibilidade de partilhar, mas também um esforço para se transportar até o conteúdo que iria ser partilhado. Este caminhar proposto por RoUSSEAU, que não era outra coisa senão a postura de sair de si ao encontro do outro, se dava por meio do diálogo, da inter-ação humana. A contribuição de Buber foi dar sequência à belíssima construção de Rousseau, a voltar a um pensamento que fosse capaz de religar o homem a ele, aos outros, e todos à transcendência.

Buber, dessa forma, não tratou de um diálogo qualquer, mas se deteve em investigar a ação transformadora para o humano, no sentido edificante da expressão. E, portanto, o filósofo austríaco entendia como um diálogo verdadeiro aquele em que as partes envolvidas não estão acertadas previamente, mas o conteúdo emerge da espontaneidade, eis que cada um se reporta diretamente a seu interlocutor e provoca nele uma imprevisível resposta. Nasce desta aproximação uma verdadeira lição que, como destaca BUBER $^{282}$, "não se produz maquinalmente, nem é tampouco uma lição cujo resultado fora conhecido de antemão pelo professor, senão uma lição que se desenvolve com surpresas para ambas as partes." Este

\footnotetext{
${ }^{282}$ Buber. Que es el hombre?. p. 147-148.
} 
diálogo é capaz de proporcionar um abraço verdadeiro e não um singelo contato físico, um embate verdadeiro e não uma simulação de concordâncias.

"O essencial não ocorre em um e outro dos participantes, nem tampouco em um mundo neutro que abarca aos dois e todas as demais coisas, senão, no sentido mais preciso, 'entre' os dois, como se disséssemos, numa dimensão da qual somente os dois tem acesso."

Um diálogo verdadeiro, contudo, exige uma curiosidade intensa das partes; requer delas uma exploração no universo do outro, uma colheita in loco das impressões que tal "viagem" deixa no seu âmago. Tomar conhecimento íntimo do outro é experimentá-lo em sua totalidade de Ser concreto, sem abstrações ou projeções que o reduzam; é tomá-lo enquanto ser autônomo, livre, e não como uma extensão de um dos interlocutores.

Pelo contrário, é considerar o homem como um-comigo, sem subtraí-lo de si mesmo e sem subtrair a oportunidade de conhecê-lo e descobri-lo enquanto ser único. É preciso se colocar de uma forma elementar em relação ao outro, para que assim ele se torne uma presença para mim. E, como destaca BUBER ${ }^{284}$, "um tal conhecimento íntimo é impossível se o outro, enquanto outro, é para mim o objeto destacado da minha contemplação ou mesmo observação (...)."

"No diálogo, não tenho a razão última de nada, não tenho a palavra final, sou dependente do jogo social, da dialética, e preciso saber jogar, saber viver. Não se trata, no dia-logos, de ganhar do outro, pois o sistema ganha-perde pode apenas produzir novas frustrações, ou vinganças. No dia-logos e na generosidade, literalmente, a palavra é

${ }^{283}$ Idem. Ibidem.
${ }^{284}$ Buber, Do diálogo..., p. 147. 
atravessada, passamos a palavra, de ouvido em ouvido; e assim damos algo, o tempo inteiro a vida é doação e serviço.",285

Nesta seara, a dinâmica do ser e parecer assume grande importância, pois uma doação aparente não é doação e assim, não permite um diálogo verdadeiro. A máscara que se equilibra em um dos rostos impede que ele seja visto em sua dignidade de rosto que é; impossibilita tanto a quem observa, como a quem é observado, experienciar o encontro fora de um e de outro, pois não se pode enviar ao plano do entre uma aparência, na medida em que ela não é capaz de oferecer ao outro a espontaneidade e a autonomia que o diálogo exige. Uma aparência só pode figurar teatralmente; apenas assume uma personagem cuja história é forjada ao sabor das circunstâncias. E este perigo tão comum nos dias atuais, o de se perder em aparências e figurações de si, foi exemplificada por BUBER ${ }^{286}$ :

"Imaginemos agora dois homens-imagens, sentados lado-a-lado e falando um-com-o-outro - chamemo-los de Pedro e Paulo - e contemos as figurações que entram em jogo. Temos de início Pedro como ele quer aparecer a Paulo e Paulo como quer aparecer a Pedro; em seguida Pedro como ele realmente aparece a Paulo, isto é, a imagem que Paulo tem de Pedro, que comumente não corresponderá de forma alguma à imagem de si que Pedro deseja que Paulo tenha e vice-versa; e ainda Pedro como aparece a si próprio e Paulo como aparece a si próprio; e finalmente, Pedro encarnado e Paulo encarnado. Dois seres vivos e seis aparências fantasmagóricas que se misturam de maneiras diversas na conversa entre os dois! Onde sobraria aqui ainda espaço para a legitimidade do inter-humano!" (grifei)

\footnotetext{
285 Pelizzoli. Op. cit, p. 07.

${ }^{286}$ Buber. Idem. p. 143.
} 
Alguns fatores impedem, o diálogo verdadeiro, e com isso interferem no crescimento do interhumano, e BUBER ${ }^{287}$ aponta para os seguintes: (i) a aparência; (ii) a percepção insuficiente; (iii) a imposição ou o empoderamento alheio. A presença de qualquer destes elementos é capaz de desequilibrar o plano dialogal, o reduzindo a um monólogo de dois expectadores.

Lembra ainda BUBER ${ }^{288}$ que uma comunicação pode prescindir de palavras, e ainda assim representar para os sujeitos envolvidos uma oportunidade de encontro e descoberta. Não é a palavra falada que singulariza o diálogo buberiano, mas sim a postura que estabelece entre os interlocutores. Um olhar pode sintetizar um diálogo, se deste olhar puder ser extraída uma relação de compreensão entre os que se entreolham; uma relação de identificação que os transversaliza e os torna próximos, ainda que nada seja dito entre eles. E essa é uma marca a partir da qual a relação inter-humana é capaz de nascer e se desenvolver das mais variadas formas, pois quando dela se falar também estará se falando de respeito, alteridade e disponibilidade - de uma comunhão amorosa, enquanto desdobramento do amor-de-si a que mencionou ROUSSEAU.

Assim como uma fala entusiasmada entre duas ou mais pessoas não é, em si, um diálogo (se os interlocutores impuserem suas posições e não se mostrarem dispostos a conhecer o outro na sua singularidade, como ele realmente é), o silêncio compreensivo e que se estabelece interiormente entre os interlocutores é capaz de construir pontes que falas despropositadas não são.

"Imaginem-se dois homens, sentados lado a lado, em algum lugar solitário do mundo. Eles não falam um com o outro, nem sequer se voltaram um para o outro. Eles não se conhecem intimamente, um nada sabe sobre a vida do outro, conheceram-se hoje cedo em suas

\footnotetext{
${ }^{287}$ Buber, Do diálogo..., p. 149-150.

${ }^{288}$ Idem, p. 35.
} 
perambulações. Nenhum dos dois pensa neste momento no outro; não precisamos saber quais os seus pensamentos. Um deles está sentado no banco comum da maneira que, obviamente, lhe é habitual: sereno, disposto de uma forma receptiva para tudo que possa acontecer; seu ser parece dizer que não é suficiente estar preparado, que é preciso estar realmente aí presente. O outro, sua atitude não o trai, é um homem reservado, controlado, mas quem o conhece sabe que desde sua infância pesa sobre ele um feitiço, que o seu autocontrole é algo mais do que uma atitude, que por trás de toda atitude está entrincheirada a impenetrável incapacidade de se comunicar. E agora - imaginemos que esta seja uma daquelas horas que conseguem romper as sete tiras de ferro que envolvem nosso coração - o feitiço dissolve-se de repente. Mas mesmo agora o homem não diz uma palavra, não move um dedo. E, entretanto, ele faz alguma coisa. A dissolução do feitiço aconteceulhe - pouco importa de onde - sem sua ação; mas eis o que este homem faz então: libera dentro de si uma reserva sobre a qual somente ele tem o poder de ação. Sem reservas, a comunicação jorra de seu interior e o silencio a leva ao seu vizinho, para quem ela era destinada e que a recebe sem reservas, como recebe todo o destino autentico que vem ao seu encontro. Ele não poderá contar a ninguém, nem a si mesmo, o que experienciou. O que 'sabe' ele agora do outro? Nenhum saber é mais necessário. Pois onde a ausência de reserva reinou entre os homens, embora sem palavras, aconteceu a palavra dialógica de uma forma sacramental."289

Portanto, não é necessário que todos os interlocutores se mostrem dispostos a estabelecer entre si uma conversação genuína e a verbalizar de forma impositiva; os que permanecem

${ }^{289}$ Buber, Do diálogo..., p. 36. 
calados podem exercer a sua presença plenamente significante através da escuta sensível ${ }^{290}$ e do olhar compreensivo e aberto. O mais importante é que cada um esteja decidido a não se esquivar, a não se subtrair, quando o curso da conversação provocar nele o desejo de dizer precisamente aquilo que tem a dizer ${ }^{291}$. É dizer: eu atuo de forma respeitosa no meu embate dialógico, aceito e compreendo os pontos de vista do meu interlocutor, mas o não abro mão de debater os meus pontos de vista; não se trata, porém, de um enfrentamento entre gladiadores prontos festejar a vitória de uma verdade - que, simplesmente, não existe de forma absoluta e igual para todos.

Os interlocutores se encontram no terreno do Entre como parceiros, se expressam de forma diversa e com conteúdos diversos, mas não deixam de ouvir ao outro para que esta fala possa ecoar em seu interior; o embate, neste sentido, é marcado também por uma sede de conhecer o outro que é muito maior do que o desejo de apoderar-se dele, pois se sabe que esta postura sufragaria a oportunidade de crescimento do Ser, e apenas reproduziria o mesmo ser em outro corpo, de forma reificante.

Ao demonstrar que considero o outro como tal, que partilho de suas angústias, mas, que discordo de seus conteúdos, estou dando oportunidade para que o outro faça o mesmo comigo, possibilitando assim um crescimento inter-humano verdadeiro, sem que se tenha a necessidade improrrogável de que do diálogo se extraia uma resolução, um fim ou uma concordância fria de idéias. O principal já foi conquistado pela oportunização de ser um e de ser outro, portanto, de serem humanos em suas singularidades e também em suas similitudes.

\footnotetext{
290 Sobre o ato da escuta, escreveu M. Pelizzoli (Op. cit, p. 07):: "Ouvir não é estar com os ouvidos abertos, mas com a obediência de coração. Ob-audere, ouvir a, ouvir para. Não se trata de ouvir e fazer pelo fato de uma lei externa e autoridade obrigar. Mas ouvir verdadeiramente é uma obediência positiva que não precisa concordar tal e qual com o outro; ela não é uma escravidão, pois é feita a partir de anseios profundos dos sujeitos humanos que são intersubjetivos no fulcro da alteridade. A incapacidade para o diálogo, tema caro à hermenêutica e às filosofias do diálogo, diz muito da incapacidade para ouvir."

${ }^{291}$ Buber. Idem, p. 155.
} 
A aceitação do outro "outramente" não importa em concordância ou aprovação com o conteúdo falado, mas o que quer que seja dito, desde que manifestado de acordo com o respeito de si e do outro, não será capaz de subtrair o cosmos que se abriu entre os interlocutores; a ponte entre eles permanecerá de pé na contrariedade, desde que subsista a certeza de que um é para o outro uma pessoa considerada tal como se expressa. Uma conversação genuína será aquela que gera tensões e inquietudes nos interlocutores, não propriamente pela diversidade de idéias, mas, sobretudo pelo novo horizonte de possibilidades que se apresenta a cada um deles. Não há um diálogo verdadeiro sem que tal agitação se faça presente no espírito dos parceiros. "Na conversação genuína, o voltar-se para o parceiro dá-se numa verdade total, ou seja, é um voltar-se do ser. Todo aquele que fala tem aqui em mente o parceiro ou os parceiros para quem se volta enquanto existência própria de pessoa." 292

“O principal pressuposto para o surgimento de uma conversação genuína é que cada um veja seu parceiro como este homem, como precisamente este homem é. Eu tomo conhecimento íntimo dele, tomo conhecimento íntimo do fato que ele é outro, essencialmente outro do que eu e essencialmente outro do que eu desta maneira determinada, única, que lhe é própria e, aceitando o homem que assim percebi, posso então dirigir minha palavra com toda a seriedade a ele, a ele precisamente enquanto tal. Talvez eu precise, a cada vez, com toda a severidade, contrapor a minha opinião à sua opinião sobre o objeto de nossa conversação; não se trata aqui, de forma alguma, de um afrouxamento de convicções, mas esta pessoa, portadora da convicção no seu caráter de pessoa, eu a aceito desta maneira de ser no qual se desenvolveu sua convicção, precisamente a convicção na qual eu precisamente tenha de tentar mostrar ponto por ponto o que ela tem de errado." ${ }^{293}$ (grifei)

Não raro as pessoas julgam desnecessário dizer o que pensam, o que para elas, ao menos até aquele ponto, representa uma verdade interior; temem magoar, e por isso se excedem no pudor a ponto de privar a si e ao outro da oportunidade de um diálogo franco, de uma

${ }^{292}$ Buber. Do diálogo..., p. 153.
Buber, Do diálogo..., p. 146. 
conversação genuína, como prefere Buber. A fidelidade do diálogo e o apreço pelo outro encetam como um imperativo a necessidade de se dizer tudo o que se pode, sem retenção do que há (e em geral pulsa) para ser dito. "Onde a palavra dialógica existe de uma forma autêntica, é pela franqueza que se deve fazer-lhe justiça. A franqueza, entretanto, é o oposto exato de um palavrear a esmo." 294

A palavra reconstrói o homem ao mesmo tempo em que firma os laços entre os seus semelhantes, o que faz BUBER reconhecer no dizer um misto de "natureza e obra, broto e formação."295

Neste contexto dialogal a Reintegração Social se apresenta como uma proposta em que a repressão, antes mesmo da compreensão, deixa de ser a tônica no discurso penitenciário. A ausência de um diálogo genuíno tem contribuído para o distanciamento a deterioração das relações já fragilizadas entre os encarcerados e a sociedade que os segrega. E tal proposta se alinha ao pensamento exposto por Alvino de Sá, no sentido de que a finalidade buscada pela Reintegração Social deve ser a de

"proporcionar aos presos experiências de liberdade. Tornar o cárcere mais humano é desconstruir aos poucos o seu sentido de cárcere ao oxigená-lo com 'ares de liberdade', com tudo o que isto possa implicar em termos de experiências construtivas para aqueles que nele vivem.,"296

A Reintegração Social, enquanto ação plural de caráter dialógico, é capaz de fomentar, um ambiente de maior compreensão entre os atores do cárcere, o que traria conseqüência imediatas na diminuição das tensões humanas já conhecidas e que não passam de um acúmulo

\footnotetext{
${ }^{294}$ Idem, p. 154.

${ }^{295}$ Idem. Ibidem.

296 Sá, Alvino Augusto de. O Caos penitenciário...Seria mesmo um caos?. Boletim IBCCRIM, v. 203, p. 15-16, 2009, p. 17.
} 
de desconfiança recíproca potencializadas pela sombra que o próprio cárcere já trata de produzir.

Por outro lado, a Reintegração Social pautada pelo diálogo seria capaz de promover uma reflexão mais abrangente acerca de formas alternativas à resolução dos conflitos sociais, entre eles a própria recomposição com a vítima e sua família, bem como moderação do conflito fora da esfera criminal $^{297}$. E isso apenas para falar do papel do conceito aplicado ao cenário criminal, já que ele, na condição de ação de promoção inter-humana, vai muito além deste âmbito.

\subsection{Reintegração Social e os vetores convergentes de responsabilidade}

Cada época constrói a sua própria neurose coletiva, conforme idéia de VIKTOR FRANKL ${ }^{298}$. Com ela, nasce uma ferida existencial capaz de retirar dos sujeitos a beleza da vida e, sobretudo, da experiência dialógica. Na atualidade, este vazio pode ser descrito como uma forma de niilismo, de negação de sentido às coisas, que passam a perder o valor que naturalmente possuem.

As pessoas perdem o seu valor, a natureza perde o valor, os animais, os objetos, enfim, tudo é e não é de forma simultânea. O que acarreta um desejo quase incontrolável de substituição dos objetos postos à disposição dos sujeitos. É preciso consumir o novo para que ele possa, ainda que precariamente, suprir as lacunas que o próprio sujeito não se encarrega de preencher, pois lhe falta o sentido humano da ação. Tanto RoUSSEAU, como Buber e também FRANKL entendem que esta "ferida existencial" que está na base dos comportamentos solitários somente poderá ser compreendida e superada a partir das experiências inter-

\footnotetext{
${ }^{297}$ Kalinsky \& Valero. Op. cit, p. 129.

${ }^{298}$ Frankl, Viktor. Conceitos fundamentais de logoterapia. In. Frankl, V. Em busca de sentido. Trad. Walter O. Schlupp e Carlos C. Aveline. 26ª ed (revista). Petrópolis/São Leopoldo: Vozes/Sinodal, 2008, p. 151.
} 
humanas; da construção de uma "vontade de sentido", segundo a proposta psicológica de Frankl $^{299}$.

A experiência Eu-Tu, como preconizada por Buber, não pode ser amesquinhada por completo pela experiência Eu-Isso, ou seja, pela relação de objetificação. As duas podem co-existir na vida humana, mas a objetificação não deve ter maior significado do que a relação interhumana e sim o contrário, sob pena de que o sujeito se projete unicamente nos objetos que estarão a ele submetidos; e se toda relação de objetificação tende a exarcebar o amor-próprio, o narciso dentro de si, é natural intuir que o sujeito perderá gradativamente a sua subjetividade e passará a se identificar com o próprio objeto de sua ação.

Não há conversação, acordo ou doação plural na objetificação. O diálogo somente consegue nascer num horizonte de simetria, de dialética ${ }^{300}$ entre os parceiros e, portanto, numa relação de sujeito $(\mathrm{Eu})$-sujeito $(\mathrm{Tu})$

"No diálogo, não tenho a razão última de nada, não tenho a palavra final, sou dependente do jogo social, da dialética, e preciso saber jogar, saber viver. Não se trata, no dia-logos, de ganhar do outro, pois o sistema ganha-perde pode apenas produzir novas frustrações, ou vinganças. No dia-logos e na generosidade, literalmente, a palavra é atravessada, passamos a palavra, de ouvido em ouvido; e assim damos algo, o tempo inteiro a vida é doação e serviço."301

\footnotetext{
${ }^{299}$ Frankl, Viktor. Um sentido para a vida. Psicoterapia e humanismo. $11^{\mathrm{a}}$ ed. Trad. Victor Hugo Silveira Lapenta. Aparecida/SP: Idéias \& Letras, 2005, p. 23. A idéia de vontade ou desejo de sentido utilizado por Frankl (p. 29) remete a uma compreensão de autotranscendência, e não propriamente de auto-realização.

300 A idéia de dialética utilizada remete ao exercício da proposição de teses igualmente validades e que se encontram para promover uma síntese, que não será a soma das idéias, senão uma nova e independente versão das delas.

${ }^{301}$ Pelizzoli. Op. cit, p. 07.
} 
Mas um fato há de ser reconhecida: o de que o amor-de-si e a pitié de Rousseau, a experiência Eu-tu de Buber e a vontade de sentido de Frankl representam conceitos que exigem engajamento e responsabilidade por parte dos sujeitos. Nenhum dos autores propôs que a existência humana edificante nasceria de um conjunto de ações automatizadas. Quando Rousseau cunhou a idéia de homem naturalmente bom, não quis com isso afastar a perversão do amor-de-si e da pitié, tanto que admitiu isso, mas apenas se referia a uma base harmônica inata ao homem em função de sua origem transcendente.

A responsabilidade é um atributo, uma postura indispensável tanto para a promoção do diálogo quanto para a sua sustentação e para o seu eventual restabelecimento. Se se julga que os homens são iguais na capacidade de dialogar, também devem sê-lo na condição de responsáveis pela sua parcela no processo interativo.

Tal afirmação que importa numa partilha de responsabilidade não deixa de reconhecer o papel das experiências sociais que são apresentadas ao sujeito, e das quais ele indiscutivelmente será tributário, em maior ou menor escala. Ninguém nega que isso seja uma verdade. A discussão não se dá na aceitação da idéia em si, senão nos limites da autonomia que restam ao individuo - o que ensejará uma maior ou menor responsabilidade perante as escolhas assumidas.

Na visão de BUBER ${ }^{302}$, o pertencimento a uma comunidade encerra uma experiência de limite à responsabilidade, de natureza mutável e não formulada em definitivo. E é importante que o sujeito tome partido desta experiência enquanto capítulo vivo de sua biografia. As alegrias e o sofrimento que farão parte do enredo de uma história individual não podem ser descartadas, mas, pelo contrário, serão valiosas na medida em que ele integrar a ambas. E BUBER, partindo de uma conceituação teológico-transcendental, vislumbra a retidão a esta história como sinônimo de retidão perante Deus.

$\overline{302}$ Buber, Do diálogo..., p. 112-113. 
Apesar disso, volta o autor a ponderar as inflexões sofridas pelo homem em decorrência da qualidade de suas práticas dialogais, que se desdobram ao longo de sua existência. Assim, para BUBER, é preciso considerar que, habitualmente, a comunidade na qual a pessoa está inserida não expressa de maneira uniforme o que ela considera como certo ou errado, válido ou inválido; ora os ideais sociais se compabilizam com o viver do sujeito, e então o sujeito ora está de acordo e outrora em desacordo, e isto sim é comum à dinâmica social.

A sociedade, por sua vez, se desmembra em grupos mais ou menos visíveis, e são eles que passam a fornecer os modelos ideais (em geral extremamente diversos) de conduta; no seio desta diversidade essencial estaria, contudo, uma reivindicação pela autenticidade que a todas as interpretações seria comum. Cada grupo tem uma compreensão do que seja útil para a comunidade; cada um deles exige para o bem coletivo a participação e o engajamento do indivíduo.

E aí surge o limite de que falava BUBER. Se o sujeito, enquanto ser social, encontra-se imerso numa miríade de grupos cujos interesses, diretrizes e posturas divergem em grande escala, é compreensível pensar que uma tal adesão a um ou a outro dos projetos sociais requer uma “entrega" do indivíduo, uma tal experiência que passa a contextualizá-lo no plano dialogal deste grupo, ao qual ele voluntariamente depositou seu interesse em se coligar.

Na grande maioria dos casos, ressalta BUBER, esta adesão não pode ser lida como um traço de definitividade e de isenção da responsabilidade pessoal; se assim fosse, dali por diante nada mais seria preciso fazer a não ser participar dos movimentos do grupo ditados pelo grupo. Aceitar esta idéia é o mesmo que acatar a circunstância de não mais haveria encruzilhadas e inexistiria a necessidade de escolhas dentre as atitudes possíveis, pois que tudo já estaria previamente decidido. Este quadro promoveria uma libertação do sujeito de si mesmo, ou seja, de sua responsabilidade perante a postura do grupo. 
A lógica da absorção completa do indivíduo pelo grupo, tese que Buber busca refutar, tem o condão de exonerar a responsabilidade, que passa a ficar eclipsada pela atuação do grupo. Assim, se antes o indivíduo creditava validade ao fato de que era emancipado e autônomo, e por isso deveria responder sempre de novo, situação após situação, pelas escolhas assumidas, o grupo agora o liberaria deste exercício. Ocorre que, como reconhece FRANKL ${ }^{303}$, "o ser humano é um ser finito e sua liberdade é restrita. Não se trata de estar livre de fatores condicionantes, mas sim da liberdade de tomar uma posição frente aos condicionamentos."

O grupo, nesta interpretação, seria uma estratégia válida apenas para aliviar a responsabilidade que cada um ostenta por si e pelos demais, ao que o autor chama de responsabilidade política. De sua leitura da responsabilidade, BuBER faz questão de aclarar que não está negando as influências que ela venha a sofrer, ou seja, ao fato de que ela pode se apresentar sob diferentes gradientes em conexão às situações concretas a que o indivíduo é submetido; o que nega é a tese de sua completa absorção pelo grupo, uma vez que, tolhido de sua responsabilidade, o indivíduo estaria igualmente absorvido de sua própria autonomia. ${ }^{304}$

"Não temos aqui de modo algum em mente que o homem deva, sozinho e desaconselhado, buscar a resposta no seu próprio seio. Não temos nada disto em mente. Como poderia a orientação daqueles que dirigem o meu grupo deixar de entrar essencialmente na substância de que é fundida a decisão? Mas a orientação não deve substituir a decisão; nenhuma substituição é aceita. Aquele que tem um mestre pode

\footnotetext{
${ }^{303}$ Frankl. Conceitos fundamentais...p. 152.

${ }^{304}$ Etimologicamente a palavra autonomia vem do grego, significando capacidade de autogestão e autogoverno (autos: próprio; nomos: regra, governo ou lei). A extensão do termo para o campo individual passou a expressar a capacidade de autogovernar a própria vida, enquanto diretriz dos próprios comportamentos. A filosofia dialógica implica o reconhecimento da autonomia enquanto um desdobramento da subjetividade humana, da escolha em definir-se de forma a privilegiar a alteridade na conduta ou, por outro lado, o narcisismo.
} 
entregar- 'se' a ele, pode entregar-lhe sua pessoa física, mas não sua responsabilidade." (grifei)

Nestes casos, pelo que se extrai da leitura do autor, não existiria propriamente um assalto à responsabilidade, mas, em casos mais extremos, uma apropriação que pressupõe ter sido ela, em algum momento, voluntariamente cedida e depositada sob a cautela do grupo. As ações que se realizarem sob os comandos do grupo, portanto, não são suficientes para, abstratamente, elidir a responsabilidade individual; isso não representa que, atuando em prol do grupo, o sujeito seja o exclusivo artífice de sua ação, pois se a prática do sujeito no grupo se deu através de uma concessão dialogal, também o grupo possui responsabilidade coletiva pelo saber propiciador da ação. Na sequência de seu pensamento, FRANKL também deixa registrada uma primeira justificativa prática de sua proposta:

“(...) é exatamente este desejo de sentido que permanece insatisfeito na sociedade atual e não encontra consideração alguma por parte da psicologia moderna. As teorias atuais sobre a motivação vêem o homem como um ser que ou reage a estímulos, ou obedece aos próprios impulsos. Estas teorias não levam em consideração o fato que, na realidade, em vez de reagir ou obedecer, o homem responde, isto é, responde às questões que a vida lhe coloca e por esta via realiza os significados que a vida lhe oferece."

ZYGMUNT BAUMAN apresenta uma interessante lição à discussão em torno da liberdade de agir e da responsabilidade decorrente desta ação. Acentua o sociólogo polonês que os excessos são fórmulas perigosas, e que o perigo de se diluir por completo a responsabilidade no coletivo também tem o seu anverso: liberdade, como quer a modernidade fluida, enquanto ato autocentrado no sujeito, individualizado e circunscrito em seu âmbito de decidibilidade; o que produziria uma responsabilização focada no agente, sem que qualquer consideração 
cultural pudesse ser apontada. Nas palavras de BAUMAN 305 "esse não pode ser o significado real da 'liberdade'; e se a liberdade 'realmente existente', a liberdade oferecida, significar tudo isso, ela não pode ser nem a garantia da felicidade, nem um objetivo digno de luta".

Uma proposta de Reintegração Social que abdica de penetrar no controverso terreno da responsabilidade humana, ao mesmo tempo em que está protegida das intempéries da discussão fica também exposta à covardia, muitas vezes companheira dos projetos ideológicos e maniqueístas. Propor o diálogo e a autonomia como exercícios de aproximação e conquista do espaço inter-humano requer a coragem de se espraiar por temas complexos para buscar uma compreensão igualmente complexa deles.

Por certo, as considerações ora lançadas não têm nenhuma pretensão de encerrar o assunto, eis que isso afrontaria a própria essência da Reintegração Social, mas apenas se está buscando a coerência teórica e epistemológica entre os fundamentos sociais e filosóficos do conceito na direção de uma possível proposta de intervenção concreta para o cenário penitenciário brasileiro.

A posição de BUBER e FRANKL a respeito da responsabilidade, e aqui aceita, pode também ser aplicada em situações efetivamente graves, quando o indivíduo de fato tem sua responsabilidade suprimida. A completa supressão da liberdade promove, em verdade, a objetificação do humano e, por isso, o desonera da responsabilidade; se está é um desdobramento da subjetividade, da autonomia, por certo não se coadunará com uma relação

\footnotetext{
${ }^{305}$ Bauman, Zigmunt. ${ }^{305}$ Bauman, Zygmunt. Modernidade líquida. Tradução de Plínio Dentzien. Rio de Janeiro: Jorge Zahar, 2001, p. 27. Abordando sua oposição a uma antropolia de orientação individualista, Buber (Buber, Que es el hombre, p. 141) consignou: "Uma antropologia individualista que se ocupa essencialmente da relação com a pessoa consigo mesma, das relações entre o espírito e o impulso dentro dela, etc, não pode levar a um conhecimento da essência do homem. (...). Somente o homem que se realiza em toda a sua vida, e o faz por completo nas relações que lhes são possíveis, pode ajudar de verdade no conhecimento do homem."
} 
de objetificação e, por isso, dela nenhuma resposta se exigirá. E a esse respeito, o criminólogo espanhol FERNANDO VILLA ${ }^{306}$ foi lapidar:

\begin{abstract}
"Se não queremos ver a sociedade como uma estrutura que nos manipula como fantoches, se estamos dispostos a reconhecer o papel de ator social no momento de recriar os papéis e situações, então teremos de aceitar o peso da responsabilidade individual. Por outro lado, dita responsabilidade apresenta uma justificativa moral: somente em situações extremas a circunstância anula o dilema que se impõe ao indivíduo em geral, e ao delinquente em particular, de fazer sofrer ou não ao outro com sua ação."
\end{abstract}

O encarcerado deve se visualizar na sociedade, e, para isso, a sociedade deve se abrir para o encarcerado, ao passo que também deve se conceber refletida nele. Há, portanto, a necessidade de que todos os atores do cenário penitenciário se co-responsabilizem pela Reintegração Social. Esta não é uma tarefa apenas dos presos ou das equipes técnicas. Também não se preconiza uma postura da vítimas, das famílias, da sociedade civil, dos movimentos políticos, dos Órgãos Administrativos e do Poder Judiciário. Trata-se de uma ação orquestrada e precisa se ramificar para que seja eficaz, entendendo por eficácia a máxima disponibilidade ao diálogo e à compreensão plural do fenômeno da criminalidade. E como disse FRANKL ${ }^{307}$, a experiência da liberdade alheia à responsabilidade corre o risco de perverter a liberdade em arbitrariedade.

“A liberdade, no entanto, não é a última palavra. Não é mais que parte da história e metade da verdade. Liberdade é apenas o aspecto negativo do fenômeno integral cujo aspecto positivo é responsabilidade. $\mathrm{Na}$

\footnotetext{
${ }^{306}$ Villa. Op. ci, p. 133-134.

${ }^{307}$ Frankl. Conceitos fundamentais...p. 154.
} 
verdade, a liberdade está em perigo de degenerar, transformando-se em mera arbitrariedade, a menos que seja vivida em termos de responsabilidade."

Interessa à Reintegração Social que cada um desses autores assuma a sua responsabilidade para com a gestão das engrenagens sociais e, assim, possam engajar-se responsavelmente não em reconstruir o passado, mas em reinventar o futuro partindo das vocações humanas do presente. Se a perspectiva dialogal conseguir êxito, os interlocutores deixarão a tradicional hostilidade e passarão a se enxergar como parceiros de uma mesma "causa": a compreensão de si, dos papéis que exercem na sociedade e, consequentemente, na busca por alternativas que possam capilarizar o diálogo nas mais variadas instâncias sociais, e não apenas no contexto do cárcere. 


\section{REINTEGRAÇÃO SOCIAL E EXECUÇÃO PENAL: DIRETRIZES DE ATUAÇÃO}

\subsection{A QUEM SE DESTINAM AS DIRETRIZES DE REINTEGRAÇÃo SOCIAL?}

No campo político a lógica narcísica impõe um quadro que CHRISTOPHER LASCH chamou de política do egoísmo esclarecido ${ }^{308}$. Trata-se de uma ocasião na qual a política é assaltada por interesses privados e independentes dos reais interesses públicos. O que vale é apenas o jogo de poder, o baile de máscaras em que a ostentação da aparência, da influência e virilidade econômica acarretam uma perversão no jogador; ele passa a ser um misto de satisfação e alheamento; goza de seu prestígio e se delicia com ele, e ao mesmo tempo se descola cada vez mais da realidade para a qual foi convocado a contribuir.

Para RoussEAU, a política deveria ser guiada com base nos corações e mentes reais, tomando como preocupação maior a satisfação de seus administrados e não o mascaramento do poder pelo poder. Não se trata de uma empreitada simples reconstruir o cenário político cujos interesses pessoais têm assumido cada vez mais o espaço público, mas esta tarefa se inicia, indubitavelmente, pela conscientização dos homens e mulheres que se somam para conformar a sociedade à espera de uma efetiva gestão pública.

É impossível se falar em Reintegração Social sem que se vá além do cárcere, sem que se atinja profundamente as estruturas sociais e políticas, a fim de provocar-lhes o diálogo sobre o cárcere e, especialmente, com o cárcere.

Por certo, em nenhum espaço social que não o cárcere se admitiria oferecer/propor algo que não fosse do aceite do interessado e do qual ele não pudesse interagir de forma ativa no processo. Poderiam dizer que o contrato de adesão, instrumento jurídico utilizado largamente

${ }^{308}$ Apud. Campos, Op. cit. p. 123. 
no mercado, seria um exemplo de proposta não discutida. Ocorre que tal mecanismo de ajuste pressupõe, de ambos os lados, a liberdade de declinar do negócio, além do que o instrumento em discussão não pode ser fruto do arbítrio do proponente, mas deve respeitar algumas regras do jogo definidas previamente pelo sistema jurídico.

Noutras palavras, mesmo a forma mais coativa de acordo civil não se compraz com a mais suave proposta de intervenção no encarcerado - a ressocialização. Vista como um benefício do detento, e não como um direito, a ressocialização, na sua forma soft, pode até mesmo admitir a participação "voluntária" nos projetos e programas oferecidos; mas o preso bem sabe que sua negativa poderá lhe custar sérios prejuízos quando da avaliação de sua conduta carcerária, pela administração penitenciária ou pelo judiciário. Portanto, a voluntariedade no cárcere, com os instrumentos que se têm à disposição, representa uma falásia.

Diferentemente dos programas de ressocialização, que se voltam exclusivamente aos presos, os projetos de Reintegração Social devem se dirigir tanto aos detentos - e, neste caso, haverá de propor estratégias de trabalho para serem implementadas dentro dos presídios - quanto a seus familiares e, especialmente, a sociedade civil.

Os trabalhos que se estendem para além do cárcere devem ter um caráter que caminha adiante da simples aproximação com o setor fabril e comercial visando o oferecimento de postos de trabalho.

O aspecto laboral é importante, mas não pode restringir o debate, pois também devem ser questionadas as condições sociais e econômicas (como escolarização dos filhos e a carência de condições materiais para o reingresso no sistema laboral) ao que, se por um lado são capazes de impor a punição, por outro devem estar devidamente estruturadas para receber de 
volta o preso. Tal recepção deverá acompanhar um processo de transformação das condições de base que propiciam as desigualdades sociais e desestabilizaram o diálogo verdadeiro.

As diretrizes que serão propostas serão dispostas em três vetores: a sociedade, os servidores penitenciários e os encarcerados. A divisão é meramente didática e apenas se presta a facilitar algumas possibilidades de implementação da Reintegração Social no contexto carcerário. Desde já importa sublinhar que os temas abordados não esgota a questão, mas apenas representa a exposição de algumas diretrizes fundamentais para o propósito de operacionalização da proposta teórica.

De antemão, vale ponderar que a Reintegração Social não é a panacéia de todos os problemas humanos e nem se propõe a ser. Como apresentado nas páginas anteriores, o conflito a diversidade é estruturante da sociedade e do próprio homem, tomado individualmente. Portanto, as diretrizes que virão não são de caráter resolutivo, mas sim reflexivo; prestam-se, a minimizar os danos atuais do encarceramento, de um lado, e a proscrever este fenômeno, de outro. Mas, definitivamente, não pretende solucionar os conflitos havidos no cárcere e fora dele, mas busca compreendê-los e fazê-los compreendidos, numa relação edificante de dialogicidade.

O cárcere, por certo, não é o melhor local para se abordar a temática da Reintegração Social, pois ele atua como um handicap (elemento de desvantagem) para a eficaz implementação das ações reintegradoras. Até por isso, a alternativa denominada Reintegração Social parte da premissa de que não se deve buscar esta reintegração do condenado através (attraverso) da pena privativa de liberdade, mas sim apesar (nonostante) e contra (contro) ela ${ }^{309}$, ou seja, ao mesmo tempo em que se oferecem mecanismos para operacionalizar a Reintegração Social no cárcere, se deve buscar com eles provocar discussões que transversalizem todas as esferas da

$\overline{{ }^{309} \text { Baratta. Reintegrazione sociale, p. } 140 .}$ 
organização social, e isto inclui aspectos políticos, sanitários, arquitetônicos, jurídicos, sociais e, especificamente, as questões de afetação humana.

\subsection{DIRETRIZES DESTINADAS À SOCIEDADE}

MARIA PALMA WOLFF ${ }^{310}$ aborda a importância da participação social no contexto da gestão de políticas públicas, e a maior integração da sociedade nos assuntos propriamente administrativos responde a duas questões: a primeira se liga ao sucateamente do Estado enquanto gestor público e a sua participação cada vez mais reduzida na sociedade; neste quadro de inoperância, a sociedade viria para assumir quinhões de poder de modo a suprir a ausência de ações concretas do Estado.

Outra forma de conceber tal participação é vê-la além da idéia de substituição gerencial, para alicerçar uma proposta de participação complementar e construção de uma hegemonia política, ou seja, de um empoderamento da questão política por parte da sociedade. As duas premissas podem ser apontadas como justificativa para a Reintegração Social.

A inclusão da sociedade nas ações afeitas ao contexto penitenciário não é de todo nova; o voluntariado está para corroborar isso; os Conselhos da Comunidade previsto na Lei de Execução Penal brasileira igualmente. A questão é que mesmo estas intervenções são tributárias das estratégias clássicas de intervenção no cárcere, pois que tradicionalmente se apresentam como instrumentos aptos a enfatizar a tolerância para com os encarcerados, sem a pretensão de buscar uma compreensão que perpasse a melhoria das condições de vida no cárcere ou a oferta de postos de trabalho após a saída do encarcerado. Tais elementos são de todo importante, mas por certo não podem ser tidos como suficientes. É possível ir além deste paradigma.

310 Wolff. Op.cit, p.82. 
Trilhando a linha mestra que já vem sendo desenvolvida durante todo este trabalho, a delimitação da idéia ou do princípio da Reintegração Social permite uma investida em searas afeitas ao campo operacional, ou seja, às propostas que podem ser levantadas de forma coerente com o que fora exposto na fundamentação teórica do conceito.

Assim, as afetações que podem ser preconizadas pela Reintegração Social penetram com vigor na seara social, a fim de levar a discussão penitenciária aos mais variados cenários públicos para, de posse deste contato, iniciar a sua proposta de diálogo, de conscientização e de reconhecimento do problema criminal como uma questão de todos, e que todos devem se engajar para compreender.

\subsubsection{Reintegração e conversão social}

A grande novidade da reintegração social é a oportunidade de conversão que ela permite. É preciso entender que a palavra conversão tal como utilizada não representa apenas a adoção de uma orientação religiosa; ela, a palavra, não se encontra restrita ao horizonte de estudo e compreensão da teologia, apesar de encontrar neste campo grande parte de seu sentido mais comumente apreendido.

Conversão é também sinônimo de transformação, de mudança de sentido, de assunção de novos rumos ${ }^{311}$. É certo que o termo ainda guarda outros sentidos, como transformação da energia libidinal em inervação somática ${ }^{312}$, para a psicanálise, além de conversão de uma coisa em outra, para a economia. O fato é que diante deste conjunto de possibilidades, a proposta de conversão aqui pontuada se liga à mais humilde e simples delas: a Reintegração

\footnotetext{
${ }^{311}$ Conforme pesquisa realizada com o termo "conversão" no Dicionário Eletrônico Houaiss. 2001.

312 O termo inervação somática aparece nas primeiras obras de Freud, em estudos com Joseph Breuer sobre a histeria.Trata-se da somatização da energia psíquica, gerando assim fenômenos motores ou sensitivos. Cf. Freud. Z. Estudos sobre a Histeria (1895b) In: FREUD, S. Estudos sobre a Histeria. ESB Vol II. Rio de Janeiro: Imago, 1996.
} 
Social enquanto ato de conversão social importa numa transformação que gera um novo jeito, uma nova forma de interpretar o desvio e a fragilidade humana.

O passo inicial para que a Reintegração Social se torne uma oportunidade de inter-ação humana, de diálogo verdadeiro, e assim capaz de concretizar o seu projeto de reinventar não apenas um cárcere - tornando-o cada vez menos cárcere, mas de reorientar os mecanismos de punição adotados pela sociedade, que em nada colaboram para a análise de suas razões, mas o que fazem é despersonalizar o homem perante o próprio homem.

É necessário que a sociedade possa se reconhecer no criminoso e responder com ele pelo desvio, ao passo que o criminoso deve se reconhecer na sociedade, para com ela trilhar formas acordadas de discutir as incongruências e desavenças próprias da existência humana. A Reintegração Social, neste particular, se mostra não como uma alternativa ao cárcere, mas sim um passo para a resolução alternativa dos conflitos sociais.

Trata-se de uma conversão capaz de fazer com que a sociedade tome conhecimento íntimo de si e do outro. Tomar posse (no sentido de investidura e não de apropriação), assumir o outro consigo, é experimentá-lo em sua totalidade de Ser concreto; sem abstrações ou projeções que o reduzam; é tomá-lo enquanto ser autônomo, livre, e não como uma extensão de um dos interlocutores. Pelo contrário, é considerar o homem como um-comigo, sem subtraí-lo de si. É preciso se colocar de uma forma elementar em relação ao outro, para que assim ele se torne uma presença para mim. E, como destaca BUBER ${ }^{313}$, "um tal conhecimento íntimo é impossível se o outro, enquanto outro, é para mim o objeto destacado da minha contemplação ou mesmo observação (...)."

313 (Buber, Do diálogo..., p. 147) 
E esta transformação precisa ser buscada pelos mais variados meios, a começar pelo próprio sistema educacional e pelo auxílio dos mecanismos de comunicação ${ }^{314}$. As novas gerações carecem de experiências construtivas com o outro, de respeito e de zelo, sobretudo com os mais vulneráveis. Importante que as crianças e os jovens possam ser apresentados a temas como o respeito à diversidade, o perdão e o amor ao próximo ${ }^{315}$, a uma forma de se relacionar através da doação efusiva, desinteressada e gratuita. Neste árduo percurso que se apresenta como contrafactual, não pode haver desânimos, mas sim esperança na missão de perpassar uma mensagem virtuosa. E mais uma vez, as palavras de BUBER $^{316}$ são inoxidáveis ao expressar que

"o funesto fatalismo do homem moderno, que vê na degeneração a natureza a natureza imutável e no infortúnio de ter-se perdido num beco sem saída o destino original do Homo Sapiens, e que rotula qualquer pensamento de uma ruptura de romantismo reacionário. Quem reconhece realmente quão longe a nossa geração se transviou da verdadeira liberdade, da livre generosidade do $\mathrm{Eu}-\mathrm{Tu}$, deve, por força do caráter de missão de todo grande conhecimento deste gênero, exercer ele próprio- mesmo que seja o único na terra a fazê-lo - o contato direto e a este não abdicar, até que os escarnecedores se assustem e percebam na voz deste homem a voz de sua própria nostalgia reprimida."

\footnotetext{
${ }^{314}$ Como destacam Elbert \& Balcarce (Op. cit, p. 108), deve haver uma "luta pela democratização dos espaços midiáticos, a fim de que a sociedade recupere seu direito de acesso à pluralidade de fontes de informação que lhe possibilitem formar suas conviç̧ões sem preconceitos subliminares."

315 "A noção de amor como caritas é ágape, caridade amorosa e comunhão amorosa são os blocos humanísticos essenciais do cristianismo, o que no fundo é uma grande lição de como viver em sociedade. Não se tratam apenas de ovelhas, não se trata de perdão barato. $\mathrm{O}$ exemplo do próprio mestre do cristianismo é lapidar: foi necessário expulsar vendilhões dos templos, enfrentar o farisaísmo, confrontar o poder, com a estratégia da nãoviolência, quase dois mil anos antes de Gandhi. Ousou-se dizer: eu não vim trazer a paz, mas a espada." (Pelizzoli, p. 05)

${ }^{316}$ Buber, Do diálogo..., p. 146.
} 
É preciso romper com o culto das "verdades" dos donatários do poder e com a força da retórica com que impõem a segregação de uns perante outros através de uma ideologia solipsista, solitária e centrada no eu. A questão da verdade, transladada para o cenário interhumano (dialógico), só pode ser compreendida como "uma comunicação um-com-o-outro tal como são." ${ }^{317}$

A importância da palavra dita ou atuada não supera o valor da postura que um assume perante o outro; postura de respeito, de abertura e de afastamento das aparências. A verdade, neste sentido, é senão uma condição prévia de possibilidade para o conteúdo da fala entre os interlocutores, da qual o próprio conteúdo do diálogo é dependente. É, portanto, “a autenticidade do inter-humano que importa; onde ela não existe, o humano também não pode ser autêntico." ${ }^{318}$

A crise do homem passa então a ser concebida como uma "crise do Entre", que se dá na base de uma descrença para com a noção de amor, que de tão ensimesmada e arraigada, se tornou estranha até mesmo para o sujeito que o tem bem escondido dentro de si. $\mathrm{O}$ amor, a amizade, a caridade, enfim, temas tão caros ao convívio social estão perdendo espaço para a individualidade, a competitividade e a acumulação desmedida. E da mesma forma que tais posturas foram sendo eclipsadas do cenário social, há de ser viável um retorno, até mesmo porque elas nunca deixaram de habitar os recôndidos do homem, que tão somente desaprenderam a se manifestar com elas de forma espontânea.

\subsubsection{Reintegração Social e municipalismo: a capilarização da mensagem}

O mais provável não é que a Reintegração Social seja prontamente refutada, mas que uma vez conhecida provoque um impacto e uma resistência em determinados setores da sociedade. $\mathrm{O}$ período de consolidação de seus pressupostos exigirá uma atuação de resistência, de um lado,

\footnotetext{
317 Buber. Idem. p. 143.

${ }^{318}$ Idem. Ibidem.
} 
e uma organização na divulgação e aproximação dos grupos sociais e dos Poderes públicos, de outro.

A utilização de redes virtuais e organizações da sociedade civil como forma de sensibilizar e angariar maior representatividade social dos trabalhos e a difusão dos seus pressupostos em todos os setores da sociedade deverá se dar da forma mais ampla possível, com o auxílio dos meios de comunicação (campanhas de conscientização na televisiva, rádio e mídias impressas), bem como o uso orquestrado das ferramentas virtuais. Tais medidas, em médio prazo, poderão colaborar para a redução das resistências que venham a surgir.

Neste horizonte é indispensável que as discussões trilhadas pela Reintegração Social possam ser distribuídas de maneira capilarizada, ou seja, devem ser capazes de atingir o maior número possível de pessoas e penetrar no mais variados universos sociais, ao invés de restarem concentradas no contexto unicamente penitenciário. Este mecanismo de difusão há de romper com o isolamento do cárcere, além de fazer mais nítidas as vozes que ecoam por trás dos muros. Como afirmou Iñaki Rivera Beiras:

“'Que suas vozes sejam ouvidas’ pode constituir um caminho válido para que a sociedade escute uma 'opinião nunca publicada' que sirva para modificar atitudes prejudiciais, estereotipadas e que, em conseqüência, traduzem uma percepção dos problemas carcerários muito alheia da realidade. Se na verdade se que que a sociedade modifique suas atitudes frente a este problema, isto irá requerer necessariamente uma (prévia) tarefa de informação (real) do que acontece em semelhante parcela de essa mesma sociedade; sem informação prévia, nada poderá modificar substancialmente seus preconceitos adquiridos." 319

${ }^{319}$ Beiras. Lineamientos garantistas. p.44. 
É neste cenário de aproximação da sociedade ao microcosmo penitenciário que WoLFF ${ }^{320}$ propõe a descentralização da gestão penitenciária, com escopo na idéia acima mencionada de capilarização do poder. Assim, nas palavras da autora,

“a participação estabelece uma relação entre descentralização e democracia, já que amplia as instâncias de negociação e, consequentemente, de conciliação entre as diferentes forças presentes na comunidade. (...)A estadualização da administração penitenciária e das políticas de segurança pública e a tendência a resolver os problemas da violência e criminalidade através de políticas represssoras, distancia e isola a comunidade do encaminhamento de seus problemas. Ao mesmo tempo em que reforça a centralização e retira qualquer autonomia da comunidade em relação às políticas adotadas.(...). A participação social no âmbito do sistema penitenciário pode, então, se constituir como possibilidade de rompimento com a naturalização das condições degradantes e das iniquidades verificadas na prisão."

Ao se falar de descentralização enquanto estratégia de aproximação da sociedade ao cárcere, de municipalização da gestão penitenciária, mister se faz indagar alguns pontos desta questão propriamente ligada ao modelo federativo de Estado. A União Federal não é a figura adequada para atender às particularidades, e nem foi idealizada para isso. Ao planificar expectativas plurais, o processo democrático centralizado na figura da União acabou por fomentar uma frustração política coletiva que vai se escalonando por todas as demais esferas do poder. Processo semelhante vem ocorrendo no plano estadual, com maior incidência nos Estados-membros cuja complexidade da máquina administrativa muito os aproxima da organização da União Federal.

${ }^{320}$ Wolff. Op. cit, p. 83. 
É no exercício da diversidade que o federalismo pós-moderno, complexo pela estrutura de seus entes, e que se pretende mais eficaz pelas exigências de uma sociedade cada vez mais consciente de seus direitos, encontrará o mote para sua reformulação.

E isso depende de ousadia, pois é urgente que se passe do avesso do federalismo, centrado na unidade representada pela União e também pela burocratização excessiva da máquina estadual, para um federalismo ao avesso, cuja maior tarefa estará em contemplar a diversidade, fazer emergir o sentimento federativo e a apreço pela democracia, facilitar a fruição dos direitos humanos e dar vazão às expectativas de uma nação que clama por justiça social. Para isso, o maior protagonista será o Município.

A proximidade das fontes de poder e a menor complexidade da máquina administrativa local, além da maior possibilidade de acompanhamento dos processos decisórios (seja pela proximidade física, seja pela relação imediata de interesses) e de participação direta na formação da vontade coletiva, são apenas dos elementos levantados a favor de uma descentralização de competências constitucionais verdadeiras que tenha como principal destinatário o ente municipal.

\subsubsection{Voluntariado de dupla via}

A atuação de voluntários no cárcere representa um dos momentos de maior abertura ao cárcere; momento em que os presos, dentro de suas celas, nos raios dos estabelecimentos (locais que, em geral, sequer as equipes de segurança conseguem livre acesso), ou nos espaços destinados a atividades laborterápicas recebem os ares vindos "do outro lado do muro". É a oportunidade que tem de perguntar sobre os acontecimentos do mundo, de seus locais de residência, seus familiares, enfim, é uma oportunidade em que podem sentir a lufada de vento que muitos associam com a sensação da liberdade física. 
Aliado ao fato de que os voluntários, atuantes nas mais diversas áreas (religiosa, educacional, artística, cultural, jurídica, laborativa, etc), lhes proporcionam uma sensação de escapismo da realidade, o mais importante é que tais contatos, quando bem orientadas, são aptas a proporcionar uma verdadeira experiência de Reintegração Social, na qual o preso se sente "gente" e o voluntário sofre na carne as angústias de ser "preso", ainda que por poucas horas; ali, naquele recinto, eles vivem os contrários da realidade e podem extrair verdadeiras lições desse momento.

Sem dúvida, de tudo que hoje ocorre no cárcere, o voluntariado bem orientado em seus propósitos e com um projeto de atuação - ou seja, não vai ao cárcere apenas para uma visita turística ou filantropia barata - este tipo de experiência é a mais construtiva e a que mais se aproxima aos pressupostos da Reintegração Social.

Uma experiência muito positiva ocorrida na Itália e narrada por BARATTA ${ }^{321}$, demonstra alguns casos em que o voluntariado não apenas se dirige para o cárcere, mas por outra via e na direção contrária, que os voluntários também partem do próprio cárcere para a sociedade. É dizer: presos vivem a experiência inter-humana, fora do cárcere, e na condição de proponentes e coordenadores de projetos. Isso é fantástico!

Ora, a sociedade é tão carente e em tantos campos. Imaginemos quantos e quantos presos não agregariam se pudessem ensinar um ofício a um jovem. Nos cárceres há tanta vida, mesmo em meio aos escombros, e basta ter uma vivência mínima para identificar potenciais incríveis, em áreas das mais diversas, passando de ofícios técnicos e atividades culturais, como música, artes plásticas, dramaturgia, e chegando em presos com formação universitária, que seriam provas vivas de que o desvio, em absoluto, não desumaniza ninguém. Uma palestra de um preso numa escola, numa creche, num curso de formação de magistrados e promotores ou

${ }^{321}$ Baratta. Op. cit, p. 147. 
numa faculdade de direito ou de educação. São tantas as possibilidades, e tantos efeitos positivos, que o espaço deste trabalho seria insuficiente para descrevê-los.

Quantos presos não foram, e muitos ainda são, exímios esportistas, e certamente se alegrariam e cresceriam muito enquanto pessoas se pudessem ter a oportunidade de ensinar a crianças e jovens uma habilidade que, por vezes, remete a um tempo saudoso de suas vidas. E estes momentos, estas experiências seriam importantes para que o sujeito reconstruísse o fio condutor que dá sentido à sua vida.

\subsubsection{Reconhecimento legal da Reintegração Social}

Uma interessante proposta apresentada por RIVERA BEIRAS ${ }^{322}$ no campo da formatação de um marco jurídico para a Reintegração Social se dá com a criação de um Grupo Independente de Trabalho (GIT), formado por representantes dos técnicos, agentes de segurança, assistentes sociais, psicólogos, advogados, voluntários e pessoas alheias ao cárcere e, sobretudo, por presos.

Este grupo não se confundiria com a conhecida, porém desenganada, Comissão Técnica de Classificação (CTC) e deve ter um corpo funcional diverso desta. O GIT deverá representar um órgão competente para apreciar as decisões técnicas relativas a conclusões afeitas à má conduta dos presos, antes que elas sejam finalmente encaminhadas ao Poder Judiciário. Tal medida se justifica, pois sendo o cárcere uma inegável experiência de degradação, quaisquer medidas tendentes a ampliar o ritual de sofrimento devem ser analisadas por um grupo plural e independente, que conte com a representação dos próprios encarcerados, para que assim seja possível reduzir ao máximo as arbitrariedades que venham a ser destinadas aos presos.

\footnotetext{
${ }^{322}$ Beiras. Op. cit, p. 30 et seq.
} 
Ademais, deverá a legislação assegurar com mais clareza, através de instrumento normativo próprio, um rol de direitos dos presos capaz de contemplar o diálogo e as experiências humanas que vão além do cárcere. E o debate preconizado pela Reintegração Social deverá questionar, com máxima urgência, os elevados índices de encarceramento da população, especialmente da população mais vulnerável.

Outras propostas que deverão fazer parte da agenda política dos militantes da Reintegração Social se referem a questões de presas grávidas ou com filhos considerados por lei como crianças, bem como a situação dos presos enfermos terminais Esta é uma discussão maior e paralela.

"A existência de um cárcere que apresenta elevadíssimas porcentagens de enfermos, infectados, alguns com patologias terminais, alojados em enfermarias penitenciárias cuja visita evoca as mais terríveis imagens de um passado ainda presente nesta realidade penitenciária, constitui um quadro que não pode admitir reforma nem melhoramentos: simplesmente se deve abolir um sistema cruel, violento e que, no final do milênio, somente pode ser qualificado como obsceno e vergonhoso." 323

Deve ser decretada, por Lei, a libertação de todos os que venham a ser acometidos por graves enfermidades no cárcere, ou que estejam padecendo de sérias patologias adquiridas previamente à prisão. Já com relação às mães, BEIRAS ${ }^{324}$ lembra que o tempo de permanência das crianças junto às mães encarceradas é variável em cada país. Em nações européias, como Dinamarca, Grã-Bretanha, Suécia, Suiça e França, lembra o autor que o tempo máximo permitido é 18 meses; já na Grécia, Austria, Luxemburgo, Italia, Portugal e Espanha, o período admitido é de até 03 anos; países latino americanos como Costa Rica, Guatemala e Colômbia autorizam a permanência por um prazo de até 06 anos. No Brasil, a Lei

\footnotetext{
${ }^{323}$ Beiras. Op. cit, p. 33

324 Beiras. Op. cit, p. 35 (nota n. 10)
} 
11.942/2008 alterou o art. 89 da Lei de Execução Penal, passando a permitir que a criança permaneça com a mãe encarcerada por um período de até 07 anos de idade.

A liberdade da mãe, neste caso, nasce reflexamente a um direito da criança, seguido de um benefício à mãe - que deve zelar pela educação do filho, a partir de um acompanhamento para que os vínculos sejam reforçados em liberdade. Enquanto isso não ocorre, o autor propõe a criação de grupos de apoio às crianças encarceradas.

\subsubsection{Reintegração Social e arquitetura penitenciária}

Ao lado das propostas afeitas a descarcerização e às reflexões críticas acerca do sentido da punição ao desvio, importa igualmente voltar os olhos para o que já está "de pé”, para o cárcere real e sua expansão. Não se trata aqui de pugnar apenas por por cárceres mais humanizados em seus espaços físicos pois, como lembrou Sá,

"O cárcere é como um funeral e um túmulo. Pode-se colocar o morto no caixão de ouro, fazer uma sessão de imemoráveis homenagens a ele, com a presença das mais diversas celebridades, colocá-lo num túmulo ornamentado com mármore dos mais caros do mundo. Apesar de tudo isso, o morto será sempre morto, o funeral não passa de funeral e o túmulo será sempre túmulo."325

Deve-se desenvolver campanhas de conscientização pública acerca da ineficácia à respeito da construção de cárceres de segurança máxima. Outra questão que deve ser frontalmente combatida se refere à construção de presídios em locais distantes e longe da visão da sociedade e pior, distante dos domicílios da maioria dos detentos.

325 Sá, Caos, p. 03. 
Como destaca BEIRAS ${ }^{326}$, “se considera igualmente nefasta a prática de 'esconder' o problema retirando-o da vista da vista dos cidadãos: a cidade deve presenciar e deve questionar a existência do cárcere e dos presos que ela mesma produz."

Além destes aspectos, um debato mais amplo transversalizado pelo princípio da Reintegração Social deve pugnar por uma “moratória em relação à construção de novos presídios”,327, a fim de iniciar um debate sério capaz de questionar as bases do modelo punitivo que se sustenta à base da multiplicação das edificações prisionais.

\subsubsection{O papel do criminólogo crítico perante a Reintegração Social}

Larrauri $^{328}$ menciona que desde a décade de 60 os teóricos ligados ao movimento crítico, no âmbito da criminologia, discutem se ele deveria ou não se comprometer com programas de redução e erradicação do crime. A autora cita, por exemplo, algumas posições divergentes expostas por grandes criminólogos partidários do movimento crítico.

Jock Young, na visão da mencionada autora, defendia que a tarefa fundamental da criminologia crítica era a de encontrar uma resposta ao fenômeno criminal, e assim a política criminal passaria a se tornar o local de grande interesse para esta perspectiva; MATHIESEN, por sua vez, defendia que a tarefa dos aportes críticos criminológicos deveria se voltar a abolir o cárcere, criticá-lo sem sugerir numa primeira abordagem nenhum tipo de alternativas a ele; por fim, alguns criminólogos críticos alemães, dentre os quais a autora cita SCHEERER e SACK, tributários diretos da influência da "teoria crítica", preconizavam que uma genuína teoria crítica somente haveria de ter como objeto a crítica e não a reconstrução.

\footnotetext{
${ }^{326}$ Beiras. Op. cit, p.37.

${ }^{327}$ Beiras. Op. cit, p.38.

${ }^{328}$ Larrauri.Op. cit. p. 237-238.
} 
A questão que tanto incomoda os criminólogos críticos preocupados com a possibilidade de que a teoria venha a se espraiar em campos práticos, não é tanto a formulação de propostas voltadas a atender os interesses político criminais, senão que o fato de que tais interesses poderiam, de certa forma, limitar o proponente através das "razões de Estado", e isto ocorreria quando o próprio criminólogo abandonasse sua posição de independência e passasse a agregar as fileiras administrativas do Estado, naufragando assim a única forma de intervenção prática aceita pela criminologia crítica, qual seja, a práxis revolucionária ${ }^{329}$.

Como adverte LARRAURI ${ }^{330}$, “dentro do poder, somente se pode reformar; a revolução desde o poder se transforma em uma gestão mais ou menos eficaz dos males sociais, que entram com ânimo progressista e acabam se escudando em 'razões de Estado'., 331

E foi o próprio MATHIESEN ${ }^{332}$, um dos criminólogos críticos mais destacado na oposição ao cárcere, que propôs uma via de compreensão (e não propriamente de atuação) entre o diálogo crítico e as pautas administrativas. Se o poder tende a representar um mecanismo de estabilização, e exatamente nisso divergia dos anseios transformadores da crítica, a aproximação entre as duas esferas haveria de ser mediada pela sociedade. Assim, defendia MATHIESEN que, excepcionalmente, poderia ocorrer uma colaboração da crítica com o poder desde que neste processo houvesse a integração de organizações exteriores, aos quais o exercício do poder estaria vinculado, sobretudo com a prestação de informações concretas ao exterior (meio social), e tudo isso por um período de tempo limitado, até que as reivindicações mais radicais pudessem iniciar sua marcha.

"Para uns, o criminólogo - como qualquer cientista social - não deve intervir na realidade, não deve aspirar a transformá-la desde posições

\footnotetext{
${ }^{329}$ Larrauri. Op. cit, p.236.

330 Laurrauri. Op. cit, p. 242. p. 242.

${ }^{331}$ Idem. Ibidem.

${ }^{332}$ Idem. Ibidem
} 
de poder. Porque o poder sempre corrompe, é dizer, porque não se pode evitar os efeitos controladores e repressores da liberdade individual das medidas políticas. A missão do criminólogo é a de criticar e a missão da crítica é a de limitar as tentações e os efeitos repressivos da política. Também há de fazer conscientes os mecanismos de poder e os efeitos muitas vezes invisíveis de discriminação dos sujeitos e grupos que simplesmente exercem seu direito a ser diferentes. Para outros, sem embargo, o criminólogo tem a responsabilidade de auxiliar as mudanças sociais exercidas pela gestão. É mais fácil escrever livros críticos desde a Universidade do que manejar os problemas práticos na cadeira de um Órgão, Conselho ou alto cargo que tenha relação com a gestão da política-criminal. (...) O político e o gestor se encontram em meio a um incêndio, posição esta, por definição, mais incômoda e difícil, mais dramática que a de teórico. Tomar partido de uma ou de outra destas posição não é fácil." ${ }^{333}$.

VILLA $^{334}$ deixa clara em seu texto a sua adesão à tese de que os criminólogos críticos devem, na medida do possível, se espraiar no campo propositivo, ou seja, na seara da política-criminal - posição que resta claro ser a adotada no presente trabalho. Portanto, a opção do autor é pela responsabilidade do criminólogo com as críticas que produz; responsabilidade que deve ser situada num cenário realista e em cotejo com as diretrizes relativas da pós-modernidade. Como sabiamente afirmou VILLA, assumir as dificuldades do caminho trilhado entre a teoria e a prática não elimina a responsabilidade moral no sentido de buscar reduzir o sofrimento do outro. “A cortesia não remove a bravura (Lo córtes no quita lo valiente), reza o provérbio castelhano.",335

\footnotetext{
333 (Villa, p. 115-116)

${ }^{334}$ Villa. Op. cit, p. 116-117.

${ }^{335}$ Villa. Op. cit, p. 116.
} 
Como arremata VILLA, o conhecimento do qual se vale a crítica poderá servir de suporte para gestão política, desde o ponto de vista do sentido comum de uma crítica construtivista. $\mathrm{Na}$ sequência, o autor elucida sua posição com o seguinte exemplo:

"Se alguém se depara, numa excursão, com uma serpente cuja coloração me traz a certeza de ser venenosa, meu conhecimento será útil ao grupo de excursionistas, independentemente de que se trate de um zoólogo especialista em répteis ou que tenha aprendido o tema num documentário do National Geographic. Porém, além de útil, meu conhecimento é responsável moralmente. Pode ser que eu tenha aprendido também que certa planta, ao ser esfregada sobre a pele, funciona como repelente para a serpente, pois bem, neste caso, devo ou não devo emitir a 'receita', mesmo que não esteja seguro de que funcione ou tenha outros efeitos de que desconheço?"336

De fato, é devastador o resultado de uma proposição crítica da realidade sem que nada de construtivo, ou seja, de mais benéfico seja proposto no lugar do que se busca implodir ou sufragar. É como disse MUÑOZ CONDE ${ }^{337}$ : não se deve pretender mudar a realidade estando à margem dela, mas é necessário coragem para mergulhar no que se pretende mudar. No mesmo sentido arremata CERVINI ${ }^{338}$ : “Assim, levando em conta a ineficácia histórica da prisão como meio para obter-se a recuperação social dos internos impõe-se, inflexivelmente, a busca de outras vias, em todas as etapas e níveis do sistema penal (...)”.

\footnotetext{
${ }^{336}$ Villa. Op. cit,, p. 117.

${ }^{337}$ Apud. Cervini, Op. cit, p. 46.

${ }^{338}$ Cervini. Op. cit, p. 47.
} 


\subsection{EQUIPE PENITENCIÁRIA}

\subsubsection{A Reintegração Social enquanto diretriz curricular na formação da equipe penitenciária}

A brutal incomunicabilidade psíquica entre funcionários e presos, a frieza, a suspeita, o temor e intransigência, somente poderão ser superados na medida em que todos os atores envolvidos tiverem conhecimento prévio de suas limitações humanas. A preparação bem orientada dos servidores penitenciários deverá orientá-los acerca do contexto que os esperam, mas, apesar dele, das intervenções construtivas que eles, como os representantes da sociedade mais próximos dos encarcerados, podem implementar.

Além disso, uma base humanística oferecida aos servidores há de torná-los pessoas mais cientes de si, de seus limites e possibilidades pessoais, favorecendo a descoberta de potenciais efetivamente vocacionados aos trabalhos no cárcere e, por outro lado, identificando a ausência desta vocação o quanto. Isso porque uma "boa prisão", ainda que tecnologicamente qualificada, pouco perdura ${ }^{339}$ sem um corpo técnico que lhe seja de gerir as frustrações e as tensões em meio a constantes crises. Por outro lado, um corpo técnico vocacionado, motivado e com razoáveis condições laborativas, é capaz de produzir resultados incríveis no sentido de concretizar o ideal da Reintegração Social. ${ }^{340}$

\footnotetext{
${ }^{339}$ Esta consideração deve ser tomada em sentido literal, pois aos que labutam no sistema prisional não é nenhuma surpresa a capacidade dos presos de "colocar no chão", em poucas horas, uma estrutura física aparentemente indestrutível. Não fosse o esforço de gerenciamento de crises (por vezes, apreendido na prática, e de forma traumática) do corpo técnico, muitas unidades prisionais noticiariam, dia após dia, a ocorrência de fugas em massa, sem que pouco ou quase nada pudesse ser feito - exceto, com desmedido derramamento de sangue .

${ }^{340}$ Neste sentido, a Associação Internacional para Prevenção da Tortura (APT), em publicação do seu "Guia prático para monitoramento em locais de detenção" (Traduzido por Fabiana Gorestein e Liana Rodrigues. Brasília: SEDH, 2006), afirma que o corpo técnico encarregado pelos detentos não pode ser ignorado, já que, em grande escala, são eles que determinam como aqueles serão tratados. Dessa forma, o fator preponderante para que um local de detenção respeite a dignidade de todos está na qualidade da relação entre o corpo técnico e os presos.
} 
"O cárcere é uma comunidade de frustração que se estende a todos os atores envolvidos nas mais diversas funções: detentos, educadores, médicos, assistentes sociais, agentes de custódia e administradores"341. Assim, desenvolver em todos a importância do princípio da simetria nas relações humanas havidas entre detentos e operadores do sistema representa a premissa para se compatibilizar a reciprocidade e aprimorar as funções. Reciprocidade das funções significa, portanto, que a interação entre os seus atores se desloca de um campo unicamente institucional para oportunizar uma autêntica comunicação, permeada por uma sensibilidade partilhada e, por isso, adequada a gerar um alivia perante o quadro de perturbação e de frustração ${ }^{342}$.

Portanto, uma reestruturação radical na grade curricular dos programas de formação de agentes penitenciários deve ser implementada, sobretudo para afastá-las de "uma formação que avance muito mais além das disciplinas criminológicas ancoradas no paradigma etiológico da criminalidade" ${ }^{343}$. Este é um passo inicial. Feito isso, é imperioso transformar o curso de iniciação (formação), que deve se pautar num currículo de viés humanístico e não numa preparação à guerra - cuja tônica é fornecida às disciplinas de viés biologicista e, no plano prático, por um volume desproporcional de matérias relacionadas a técnicas de segurança pessoal, manuseio de arma de fogo e tudo que remeta ao aluno a um cenário catastrófico.

O aluno que recebe uma instrução deste teor, para o combate, por certo ingressará no sistema acreditando fielmente ser um "justiceiro". Assim, tais propostas não contribuem nem para o homem que ingressa no cárcere enquanto servidor, nem para o homem que lá se encontra purgando sua pena. Para os que entram, ensinam a despersonalizar o humano, e para o que se

\footnotetext{
${ }^{341}$ Baratta. Op. cit, p. 147.

${ }^{342}$ Idem. Ibidem.

${ }^{343}$ Beiras. Op. cit, p. 30-31.
} 
encontra preso tal treinamento apenas amplia a distância social iniciada com o encarceramento.

Portanto, antes de fomentar o mito do "Rambo",344, especialmente nos agentes de segurança penitenciária, se deve priorizar que eles conheçam de ser humano muito mais do que de armamento; que saibam técnicas de negociação e tenham intimidade com a comunicação nãoviolenta. Esta diretiva deve partir dos Órgãos Federais, no caso brasileiro, o Departamento Penitenciário Federal (DEPEN), e se disseminar por todos os cenários estaduais.

Junto a isso, é de fundamental importância oferecer condições dignas a partir do momento em que o servidor ingressa no cárcere. Lá, tal como os presos, ele será submetido a uma debilitação física e psíquica e a uma frustração intensas. Portanto, além de salários condizentes ao grau de vulnerabilidade a que estarão expostos, estes profissionais devem contar com um atuante Órgão Sindical, que se interesse por seus assistidos e, quando possível, se aproxime das instituições sociais e das Universidades para que, conjuntamente, possam refletir criticamente o quadro laboral e a sua superação.

RIVERA BEIRAS $^{345}$ recorda um exemplo muito elucidativo no poder de mobilização que a aliança entre profissionais penitenciários e o contexto acadêmico pode acarretar. Retrata o autor que o contato entre operadores penitenciários e setores acadêmicos ligados à Universidade de Bologna na Itália se traduziu num conjunto de ações, como seminários, discussões e debates. A idéia central era a de refletir as razões da própria intervenção de psicólogos e educadores nos presídios italianos. O questionamento sobre as formas de intervenção deram margem a criação de um efetivo movimento entre os técnicos, que

\footnotetext{
${ }^{344}$ A expressão foi cunhada ex improviso, e por isso não encontra precedente na literatura. De toda forma, a idéia foi a de transmitir o estímulo que muitos programas de formação passam aos aluno de que a maior qualidade do seu serviço está relacionada a perspicácia e a sagacidade de pôr em prática suas técnicas de defesa, suas armas "não letais" (mas que matam e machucam, se utilizadas de forma inescrupulosa) e seu poder de destruição. 345 (p. 40, nota n. 14)
} 
passaram a questionar a própria administração que os empregava em torno de questões como “quem ressocializamos?” ou "para que ressocializamos?” etc.

Tal iniciativa demonstrou que a reflexão é capaz de manter sempre acessa, sempre viva a "experiência do assombro", qual seja, a inquietação pelas condições aviltantes em que funcionam os cárceres e os desdobramentos de suas práticas tradicionais tanto na pele dos servidores quanto na carne dos encarcerados. Enfim, é preciso estimular nos servidores a manutenção da sensibilidade humana, da afetividade que é capaz de religar o homem independentemente do contexto em que ele se encontre.

E isso não quer dizer que as discussões penitenciárias estejam restritas ao contexto técnico. Pelo contrário, a exposição deixou claro, inclusive de forma proposital, que antes e chegar numa discussão que afeta o interior do cárcere, se faz necessário recriar condições de fraternidade e pitié fora dele. "É a sociedade que cria, mantém e reproduz o cárcere e os presos que temos. Em conseqüência, há de ser esta mesma sociedade a que deve buscar fórmulas para a sua superação" 346 . Isso é o que BARATTA chama de destecnizaçao, que não se trata de um desvalor do papel dos servidores; pelo contrário, se trata apenas de retira-lhes a exclusividade pela gestão de todos os projetos aplicados no cárcere, dentre eles os projetos de Reintegração Social.

\subsubsection{Simetria e abrangência das ações de Reintegração Social}

Deve haver uma especial atenção às ações voltadas a tornar mais adequadas as condições familiares, ambientais e, também, a interface entre a sociedade e o cárcere. Ao mesmo tempo, se deve promover a formação de atitudes favoráveis à reintegração social do ex-detento através de programas de informação e de integração cultural, debates públicos e encontros com a participação tanto de detentos como de ex-detentos ${ }^{347}$. Toda aquela rede de informação

\footnotetext{
${ }^{346}$ Beiras. Op. cit, p.42.

${ }^{347}$ Baratta. Op. cit p. 143.
} 
abordada alguns pontos acima deve ser acionada para que o ex-detento encontre dentro da sociedade um grupo que, de imediato, confia nele, o estimula e o reforça enquanto ser humano.

Este será um importante estágio no processo de reintegração do sujeito, que ainda sofre a experiência desagregadora do cárcere, mas por certo estará a cada dia mais fortificado subjetivamente enquanto encontrar no olhar que lhe fita uma luz que o desperta a ser humano, que o respeita enquanto pessoa com toda a sua história de vida e que lhe fornece a dignidade que somente uma relação amorosa e fraternal é capaz de lhe dar. Ao que ele retribui o olhar, o sorriso e o afeto. Fez-se, então, o diálogo inter-humano.

Os programas de Reintegração Social também não devem fazer distinções entre presos condenados e provisórios, mas deve, junto a todos, experimentar o diálogo e o conhecimento dual, inclusive com ex-detentos que ainda queiram continuar nos grupos - fato que dará um colorido ainda mais interessante, tanto aos que ficaram quanto ao que já foi mas, voluntariamente, retornou para prosseguir no seu processo de aprendizado humano. Portanto,

\footnotetext{
"se os programas e os serviços são independentes do contexto punitivodisciplinar, seus conteúdos não necessitam nem permitem uma divisão rígida ou solução de continuidade relativa à condição de detento ou exdetento dos seus usuários.",348
}

A continuação estrutural dos programas mesmo após a soltura do encarcerado, que então não é mais encarcerado senão ex-encarcerado, representa um fator integrante da proposta de abertura recíproca entre o cárcere e a sociedade, de superação da barreira simbólica erigida entre os mundos (tidos no plural igualmente por um esforço simbólico). Portanto, a

\footnotetext{
${ }^{348}$ Baratta. Op. cit. p.146.
} 
reintegração social deve mirar dois horizontes, reciprocamente: o horizonte dos detentos e exdetentos e o ambiente e sua estrutura social.

Neste espaço, seria muitíssimo valiosa a proposta de ouvir os presos acerca das medidas adotadas pela administração, e dos quais eles são os maiores interessados. Esta abertura, este diálogo entre presos e administração penitenciária, terá o condão de jogar por terra o estigma de "periculosidade" que paira sobre os internos, como se fossem incapazes de negociar seus reclamos e de se resignarem (e não apenas se submeterem) perante as decisões administrativas.

Ao lado dos ganhos no campo microcosmos social do cárcere, a participação de detentos e exdetentos em setores da administração pública encarregados da administração penitenciária tais como Secretarias e Departamentos estaduais -, terá o condão de desmitificar a visão que a sociedade não raro nutre do preso como um "guerreiro das trevas", um indivíduo "perigoso".

Tanto é assim que nas ocasiões em que a sociedade se propõe a visitar o cárcere, e o faz, como em diversas visitas de universitários curiosos, apenas para conhecer o espaço e ver os "bichinhos na jaula" (lógica do zoológico) e para perguntar como é a vida na cadeia, não há interesse manifesto no diálogo, em penetrar na realidade e na história de vida do homem à frente (e não por trás) do preso. E dar voz aos encarcerados seria um ato concreto de propiciar o diálogo, que não se faz através do silêncio forjado pelos muros do cárcere.

\subsection{Diretrizes destinadas aos encarcerados}

\subsubsection{Leitura prévia do campo}

Antes de se iniciar qualquer proposta de reintegração social é imprescindível que os proponentes tenham uma radiografia segura da realidade carcerária a ser trabalhada. É preciso 
definir qual a perfil da população carcerária, quais os seus problemas mais urgentes, as suas demandas e também sugestões, haja vista que será com este grupo concreto que se irá trabalhar. Portanto, é fundamental se ter em conta os atores principais: os presos, os seus familiares, os servidores penitenciários e as associações de apoio (ONG's e instituições voluntárias).

Quanto maior o número de informações, mais personalizada será a proposta de Reintegração Social e mais potencializadas serão as suas experiências. De outro lado, não é menos importante que os presos sejam igualmente comunicados do maior volume de dados possíveis acerca dos trabalhos e dos grupos que pretendem realizar o trabalho. E isso vale tanto para grupos de servidores penitenciários quanto para grupos de voluntários. A égide de qualquer trabalho no campo da Reintegração Social há de ser a transparência e a simetria, sem as quais o diálogo e a relação inter-humana fica seriamente prejudicada.

Este conjunto selecionado de pessoas formará a Comissão de Reintegração Social. Será por meio deste grupo que as principais questões sensíveis e de interesse de todos haverão de ser formuladas e discutidas para que, na sequência, possam avançar em direção ao espaço público.

Traçar um perfil dos envolvidos nas propostas e levantar as demandas concretas deste grupo deve ser uma etapa preparatória a qualquer programa de reintegração. O segundo passo, ainda na fase preliminar, será o de prestar uma devolutiva deste primeiro material ou informe, redigido com os dados adquiridos da realidade e dos pleitos formulados, a fim de que os envolvidos os considerem, corrijam e indiquem adaptações, até que seja extraído um documento fruto do consenso. Estes passos, portanto, marcarão o ponto de partida dos trabalhos. 
Em geral, os trabalhos oferecidos no cárcere guardam uma relação estreita com o cenário disciplinar. A participação nos projetos e trabalhos é, com elevada freqüência, utilizada como "moeda de troca" pelos técnicos e servidores penitenciários aos presos mais considerados mais ordeiros e gentis.

Esta lógica premial tende a distanciar ainda mais o pessoal penitenciários dos que mais precisam de suporte humano, por guardarem em sua história um diálogo humano fragilizado e manifestado pelo canal da violência. Portanto, as propostas calcadas no princípio da reintegração social devem se afastar do arbítrio que é tão naturalizado no contexto penitenciário, a fim de privilegiar a equidade como diretriz de trabalho e assim promover debates e encontros verdadeiros, e isso pode ocorrer em meio a tensões permeadas por visões de mundo diversas, mas que devem, exatamente em prol da diversidade, caminhar no sentido da síntese e da compreensão.

As propostas alinhadas com o princípio da reintegração devem ter como linha básica a circunstância de que os presos não são objeto (tal como eram considerados pelas idéias de tratamento penitenciário e ressocialização), mas sim sujeitos capazes de opinar acerca do que lhes oferecido e, sobretudo, de participar da formatação dos trabalhos enquanto pessoas tão interessadas quanto os técnicos, uma vez que se falará num horizonte de mutua compreensão e não mais de doutrinamento.

A Reintegração Social, em resumo, tem a finalidade de promover a progressiva desistintucionalização do controle do desvio. As características distintivas da reintegração social, neste contexto, são: dentro e fora do cárcere; sua dupla direção (doppia direzione) tanto para o preso quanto para a sociedade; a troca de papéis; destecnização (que não significa eliminação dos trabalhos técnicos mas, pelo contrário, se trata de de uma via de valorização das funções técnicas tanto na organização penitenciária quanto na assistência pós-carcerária). 
Por destecnização se deve compreender a multiplicação de funções, profissionais e não profissionais, que tem por fundamento a extensão universal da competência a vários atores na realização da estratégia de reintegração social. 


\section{CONCLUSÃO}

Costuma-se dizer que ninguém conhece verdadeiramente uma nação até que tenha estado dentro de suas prisões. E, neste contexto, uma nação não deve ser avaliada pelo modo como trata os cidadãos mais elevados, mas sim, pela forma como cuida de seus cidadãos marginalizados. Essa foi a mensagem deixada por NELSON MANDELA ${ }^{349}$. Com esta consideração, um dos mais célebres ex-prisioneiros do mundo, irrompeu o silêncio que o cárcere o impôs durante mais de duas décadas.

Metaforicamente, o encarceramento promove um desmoronamento tanto para a sociedade quanto para o próprio encarcerado, e os resultados desta tragédia estão, há tempos, à disposição da sociedade. Se parte da sociedade prefere, consciente ou inconscientemente, morrer e deixar morrer através do cárcere, é possível divisar outra parcela desta mesma sociedade que prefere resgatar as vítimas soterradas e, concomitante a isso, pugnar pela erradicação da tragédia, por meio da desocupação gradativa das ditas “áreas de risco".

As propostas encartadas sob a orientação do princípio de Reintegração Social não se prestam apenas a frear o processo de destruição pessoal promovida pelo encarceramento, mas preconizam o início de um processo de resgate humano em meio aos destroços. Resgate esse que pode ser instaurado e operacionalizado por uma vocação humana, hoje em desuso, mas que nunca se apaga, que é a o amor ágape, amor caridoso, realização que somente pode ser conquistada no plano relacional e por meio do diálogo.

${ }^{349}$ Cf. Guia prático para monitoramento em locais de detenção. Trad. por Fabiana Gorestein e Liana Rodrigues. Brasília: SEDH, 2006. 
O cárcere, tal como um solapamento de terra sobre um grupamento social, não pode arrefecer a esperança de se resgatarem vidas que, independentemente do número, justificam e fornecem sentido às ações.

O filósofo espanhol JosÉ ORTEGA Y GASSET ${ }^{350}$ falava na "barbárie da especialização" para se referir ao fato de que todo estudo, toda a experiência, tende a especializar e "barbarizar" os envolvidos, pois enquanto sujeitos de um processo investigativo determinado ou de uma experiência concreta limitada, os personagens estão alheios a tudo o mais que ocorre fora de seu reduzido campo de percepção.

Inevitavelmente, como expõe ORTEGA Y GASSET, a finitude perceptiva transforma o homem em estrangeiro de sua própria época, em estranho dos horizontes que não vivencia e nem procura conhecer. O cárcere tende a limitar ainda mais as restritas possibilidades de conhecimento à disposição dos homens, e isso vale tanto para quem está dentro dele quando para os que estão fora; a inacessibilidade é a mesma, pois tanto o olhar de dentro quanto o olhar de fora esbarram no mesmo muro, numa mesma limitação de encontro, numa singular privação da experiência de seu humano.

A incomunicabilidade imposta pelo cárcere, afeta a todos, tanto aos que se encontram presos de um lado, como os que ficam aprisionados do outro, mas "talvez haja uma pequena vantagem para os que estão do lado de 'dentro' da porta, pois, sem dúvida, possuem maior consciência de que estão realmente incomunicáveis do que os presos do outro lado e, obviamente, a liberdade começa com a tomada de consciência da realidade.”, 351

As idéias centrais da pesquisa são, em sua grande maioria, idéias desacreditadas por grande parcela da sociedade. Isso poderia gerar uma frustração, um sentimento de se estar levantando

${ }^{350}$ Apud. Perez \& Ramos. Op. cit. p. 184.

${ }^{351}$ Idem. Ibidem. 
pétalas já murchas ao ar, que com a mesma rapidez que sobem são capazes de se manter. Ocorre que assumir uma tal postura passiva, deixar de firmar as diferença existente entre as políticas tradicionais e as ações de Reintegração Social, deixar de se posicionar, de fiscalizar e cobrar que as práticas penitenciárias possam atuar conforme elas, enfim, tudo isso é pouco se assumido como uma tarefa pessoal e diária.

Como disse Buber, se pretendemos dedicar atenção aos assuntos do presente, devemos desde já preparar os de amanhã, pois se não desenvolvemos em nós e nas gerações que nos sucederão na gestão da sociedade os dons humanos, que dinheiro algum é capaz de adquirir, poderemos estar abdicando de uma vida plena hoje e amanhã. Este dom de que fala BuBER é a fantasia do real, um dom que não é um simples olhar para outro olhar; mas é uma dádiva de poder penetrar de forma audaciosa no outro ${ }^{352}$.

Quando perguntaram a BUBER se ele estava certo de que seus projetos filosóficos "dariam certo", de que eles arrebatariam as pessoas, BUBER então disse, com a humildade de um humano que prescinde do conhecimento teórico da filosofia: Eu não sei!. Não há certezas quando se vale em investir no aspecto propriamente humano; o que existem, e isso é certo, são os riscos da empreitada, e que o autor diz não ter dúvida preferir assumí-los a ter uma existência inexistente.

352 Buber, Do diálogo..., p. 148. 


\section{BIBLIOGRAFIA}

Agostinho, Santo. O livre-arbítrio. Trad: Nair de Assis Oliveira. $5^{\text {a }}$ edição. São Paulo: Paulus, 2008.

Aquino, São Tomás. Suma Teológica. I Parte. Trad: Alexandre Correa. $2^{a}$ edição. Caxias do Sul: Sulina Editora, 1980.

Araújo, Cláudio Theotonio; Menezes, Marco Antonio de. Execução penal, exame criminológico e apreciação dos indicadores de potencial criminógeno. In: Rigonatti, Sérgio Paulo (Org.). Temas em psiquiatria forense e psicologia jurídica. São Paulo: Vetro, 2003.

Baratta, A. Reintegrazione Sociale. Ridefinizione Del concetto ed elementi di operazionalizzazione. Dei Delitti e Delle Pene: Rivista de Studi Sociali, Storici e Giuridici Sulla Questione Criminale. n. 3, 1994/1996.

- Criminologia crítica e crítica do direito penal. Introdução à sociologia do direito penal. $3^{\mathrm{a}}$ ed. Rio de Janeiro: ICC/Revan, 2002.

- Observaciones sobre las funciones de la cárcel en la producción de las relaciones sociales de desigualdad. In: Baratta, A. Criminología y sistema penal (compilación in memoriam). Montevidéo/Buenos Aires: Editorial Bdef, 2004.

. Por um concepto critico de reintegración social Del condenado. In: Oliveira,

E. [Coord.]. Criminologia crítica. Fórum Internacional de Criminologia Crítica. Belém: Cejup, 1990

Bauman, Zygmunt. Modernidade líquida. Tradução de Plínio Dentzien. Rio de Janeiro: Jorge Zahar, 2001.

Beiras, Iñaki Rivera. La cuestión carcelaria - historia, epistemologia, derecho y política penitenciaria. $2^{\mathrm{a}}$ Ed. V. I. Buenos Aires: Del Puerto, 2009. 
- Lineamientos garantistas para uma transformación radical y reduccionista de La cárcel (uma visión desde España). Delito y sociedad. Revista de Ciencias Sociais. n. 14. v.9. 2000.

Bergalli, Roberto. Crítica a La criminologia. Hacia uma teoria crítica Del control social em América Latina. Bogotá: Editorial Temis, 1982.

; Ramirez, Juan Bustos; Miralles, Teresa. El pensamiento criminológico. Vol

I. Bogotá: Editorial Temis, 1983.

Beristain, Antonio. Re-encantamento criminológico en projimidad desde el desencantamiento. In: Beristain, Antonio. Derecho Penal, Criminologia y Victmologia. Curitiba: Juruá, 2007.

Bitencourt, Cezar Roberto. Criminologia crítica e o mito da função ressocializadora da pena. In: Tratado de direito penal. Vol I. 13a ed. São Paulo: Saraiva, 2008.

. Tratado de direito penal. Vol I. $13^{\mathrm{a}}$ ed. São Paulo: Saraiva, 2008.

Bock, Ana Mercês Maria et al. Psicologias: uma introdução ao estudo da psicologia. $13^{a}$ edição. São Paulo: Saraiva, 2002.

Bray, L. de. Servicio social e delincuencia. Madrid: Aguilar, 1973.

Buber, Martin. Do diálogo e do dialógico. Trad. Maria Ekstein de Souza Queiroz e Regina Weinberg. São Paulo: Perspectiva, 2007, p. 147.

Qué es el hombre. Breviarios del Fondo de Cultura Económica. Madrid: Ediciones F.C.E España, 1949.

Caffarena, Borja Mapelli. Desviación y resocialización. Cuadernos de Política Criminal. n.23, 1984. 
Campos, Edemilson Antunes de. A tirania de narciso: alteridade, narcisismo e política. São Paulo: Annablume/Fapesp, 2001,

Carlos María Landecho, S.J. La tipificación Lombrosiana de delicuentes. Tomo I. Madrid: Universidad Nacional de Educación a Distancia, 2004.

Carrara, Ozanan Vicente. Levínas: do sujeito ético ao sujeito político: elementos para pensar a política outramente. Aparecida/SP: Idéias \& Letras, 2010.

Castiglione, Teodolindo. Lombroso perante a criminologia. São Paulo: Saraiva, 1962.

Cervini, Raúl. Os processos de descriminalização. Trad. da $2^{\mathrm{a}}$ ed. espanhola Luiz Flávio Gomes. São Paulo: RT, 1995

Clemmer, Donald .The prison comommunity. New York: Holt, Rinehart and Wilson, 1958.

Cortella, Mario Sergio; De La Taille, Yves. Nos labirintos da moral. Campinas: Papirus, 2005.

Costa, Alvaro Mayrink da.Criminologia. $3^{\text {a }}$ Ed. Vol I. Tomo I. Rio de Janeiro: Forense, 1982.

Debuyst, Christian; Digneffe, Fronçoise; Pires, Alvaro P. Histoire des saviors sur le crime \& la peine. Vol. II. Montreal/Otawa: De Boeck Université, 1995.

Dias, José de Figueiredo; Andrade, Manuel da Costa. Criminologia. O homem delinqüente e a sociedade criminógena. $2^{\mathrm{a}}$ reimpressão. Coimbra: Coimbra Editora, 1997.

Dicionário Eletrônico Houaiss (2001)

Elbert \& Balcarce (Exclusión y castigo en la sociedad global. Montevideo/Buenos Aires: BdeF, 2009, p. 27.

Villa, Fernando Gil. La delincuencia e su circusntancia. Sociología Del crimen y la desviación. Valencia: Tirant lo Blanch, 2004.

Ferraz Junior, Tércio Sampaio. Estudos de filosofia do direito. $2^{a}$ edição. São Paulo: Atlas, 2003. 
Ferri, Enrico. Princípios de direito criminal: o criminoso e o crime. $2^{\mathrm{a}}$ ed. Trad. Paolo Capitanio. Campinas: Bookseller, 2003.

Filippi, Leonardo; Spangher, Giorgio. Diritto penitenziario. Milão: Giuffré, 2000.

Foucault, Michel. Vigiar e punir. O nascimento da prisão. Tradução Raquel Ramalhete. 32. Ed Petrópolis: Vozes, 1987.

Frankl, Viktor. Conceitos fundamentais de logoterapia. In. Frankl, V. Em busca de sentido. Trad. Walter O. Schlupp e Carlos C. Aveline. 26a ed (revista). Petrópolis/São Leopoldo: Vozes/Sinodal, 2008.

. Um sentido para a vida. Psicoterapia e humanismo. $11^{\mathrm{a}}$ ed. Trad. Victor Hugo Silveira Lapenta. Aparecida/SP: Idéias \& Letras, 2005.

Freud. Z. Estudos sobre a Histeria (1895b) In: FREUD, S. Estudos sobre a Histeria. ESB Vol II. Rio de Janeiro: Imago, 1996.

Garland, David. A cultura do controle. Crime e ordem social na sociedade contemporânea. Trad. André Nascimento. Rio de Janeiro: Revan, 2008.

Garófalo, Raffaele. La criminología. Estudio sobre el delito y sobre la teoría de la repression. Montevideo/Buenos Aires: Editorial Bdef, 2005.

Genovés, Vicente Garrido. Técnicas de tratamiento para delincuentes. Madrid: Editorial Centro de Estudios Ramón Areces, s.d.

Gilson, Étienne. O espírito da filosofia medieval. Trad: Eduardo Brandão. São Paulo: Martins Fontes. 2006.

Goffman, Erving. Manicomios, prisões e conventos. Trad. Dante Moreira Leite. 4 ed. São Paulo: Perspectiva, 1992.

Guia prático para monitoramento em locais de detenção" (Traduzido por Fabiana Gorestein e Liana Rodrigues. Brasília: SEDH, 2006 
Kalinsky, Beatriz; Valero, Miguel. Democratizar la cárcel: una contradicción de términos? Capítulo Criminológico: Revista de las Disciplinas del Control Social. n. 2, v. 25, 1997.

Labadie, Jean-Michel. Les mots du crime - approuche épistémologique de quelques discours sur le criminel. Montreal/Otawa: De Boeck Université, 1995.

Lombroso, Cesare. O homem delinquente. Trad. Maristela Blegi Tomasini e Oscar Antonio Corbo Garcia. Porto Alegre: Ricardo Lenz, 2001.

Lyra, Roberto; Araújo Jr., João Marcello. Criminologia. $4^{\text {a }}$ Ed. Rio de Janeiro: Forense, 1995. Maíllo, Alfonso Serrano. Introdução à criminologia. Trad. Luiz Regis Prado. São Paulo: RT, 2007.

Marconi, Marina de Andrarde; Lakatos, Eva Maria. Fundamentos de metodologia científica. $5^{\mathrm{a}}$ Ed. São Paulo: Atlas, 2003.

Melo, Fabio. Quem me roubou de mim? O sequestro da subjetividade e o desafio de ser pessoa. 66 ${ }^{\mathrm{a}}$ ed. São Paulo: Canção Nova, 2009.

Miralles, Teresa. O controle formal: La cárcel. In: Bergalli, Roberto; Ramirez, Juan Bustos; et ali. El pensamiento criminológico. Vol II. Bogotá: Editorial Temis, 1983.

Molina, Antonio Gárcia-Pablos. La supuesta función resocilizadora del derecho penal: utopia, mito y eufemismo. Anuário de Derecho Penal y Ciencias Penales. n.2. v. 32, 1979.

Molina, Antonio Pablos Garcia; Gomes, Luiz Flavio. Criminologia. 6a ed. São Paulo: RT, 2008.

Neuman, Elías. Prisón, La inhumanidad de lo humano. Pensamento Penal Del Sur. v. II, 2006.

Orsi, João Paulo. .Direito penal canônico. São Paulo: Ltr, 2009.

Orwell, George. 1984. Trad. Luiz Carlos Carneiro de Paulo. Rio de Janeiro: Bibliex, 2007. 
Pavarini, Massimo. El "punto de vista" dominante y la violência institucional: procesos de reencarcelamiento em el mundo. In: Bergalli, Roberto; Beiras, Iñaki Rivera; et al. Violencia y sistema penal. Buenos Aires: Del Puerto, 2008.

Pelizzoli, Marcelo. Fundamentos para a restauração da justiça. Resolução de conflitos, justiça restaurativa e a ética da alteridadeldiálogo. < < ww. idcb.org.br/documentos/artigos040806/fundamentospararestauracaojustica.pdf, acessado em 24.02.2011.

Perez, Miguel Fernandez. El derecho fundamental a la reconstruccion de la persona em las prisiones. Eguzkilore. Cuaderno del Instituto Vasco de Criminologia. n.8. San Sebastián, 1994, p. 151.

; Ramos, Victoriano Gracia-Redondo. Tolerancia y antropologia pedagogica de la comprension: utopia, carcel real y legislacion de la hipocresia social. Eguzkilore. Cuaderno del Instituto Vasco de Criminologia. n.8 (extraordinario). San Sebastián, 1995.

Prado, Carolina. Trabajo, exclusión y cárcel (en el empuje neoliberal hacia las fronteras del proyeto de las sociedades democráticas). In: Bergalli, Roberto; Beiras, Iñaki Rivera; et al. Violencia y sistema penal. Buenos Aires: Del Puerto, 2008.

Rauter, Cristina. Criminologia e subjetividade no Brasil. Rio de Janeiro: Revan/ICC, 2003.

Ribeiro, Bruno de Moraes. As modificações recentes havidas no conceito de ressocilização ou reintegração social e a discussão atual acerca desse conceito. In: Prado, Luiz Regis. Direito Penal Contemporâneo: estudos em homenagem ao professor José Cerezo Mir. São Paulo: RT, 2007.

Ribeiro, Bruno de Morais. Medidas de segurança. Porto Alegre: Sergio Antonio Fabris, 1998.

Rita, Rosangela Peixoto Santa. Mães e crianças atrás das grades: em questão o princípio da dignidade da pessoa humana. Brasília: Ministério da Justiça, 2007. 
Rush, Fred. As bases conceituais da primeira teoria crítica. In: Rush, Fred (org.). Teoria crítica. Trad. Beatriz Katinsky e Regina Andrés Rebollo. Aparecida: Idéias \& Letras, 2008.

Rusche, Georg; Kirchheimer, Otto. Punição e estrutura social. Trad. Gizlene Neder. 2 ed. Rio de Janeiro: Revan, 2004.

Sá, Alvino Augusto de. de. Transdiciplinaridade e responsabilidade da academia na questão penitenciária. In: - Criminologia clínica e psicologia criminal. São Paulo: RT, 2007.

. Criminologia clínica e psicologia criminal. $2^{\mathrm{a}}$ ed. São Paulo: RT, 2010. . GDUCC - Grupo de Diálogo Universidade, Cárcere, Sociedade: uma experiência que está dando certo. Boletim IBCCRIM, v. 198, p. 11-12, 2009. . Manual de projetos de reintegração social. São Paulo: SAP/DRSP, .s.d. O Caos penitenciário...Seria mesmo um caos?. Boletim IBCCRIM, v. 203, p. 15-16, 2009.

- Prisionização: um dilema para o cárcere e um desafio para a comunidade. In. Sá. A. A. Criminologia clínica e psicologia criminal. São Paulo: RT, 2007.

Sawaia, Bader. Exclusão ou inclusão perversa? In. Sawaia, bader (Org.). As artimanhas da exclusão: análise psicossocial e ética da desigualdade social. 10 $10^{\mathrm{a}}$ ed. Petrópolis/RJ: Vozes, 2010.

Seelig, Ernst. Manual de criminologia. Vol. I. Trad. Guilherme de Oliveira. Coimbra: Arménio Amado Editor, 1957.

Shecaira, Sérgio Salomão. Criminologia. São Paulo: RT, 2004. 
Shimizu, Bruno. Um panorama crítico sobre o pensamento criminológico clínico no Brasil. In: Sá, Alvino Augusto; Tangerino, Davi de Paiva Costa; Shecaira, Sérgio Salomão. Criminologia no Brasil. História e aplicações clínicas e sociológicas. Rio de Janeiro: Elsevier, 2011.

Soares, Luiz Eduardo; et alii. Cabeça de porco. Rio de Janeiro: Objetiva, 2005.

Sodré, Filipe Knaak. O direito penal e a vingança do Leopardo. Porto Alegre: Nuria Fabris, 2011.

Wolff, Maria Palma. Prisões e participação social. In. Segurança pública: uma abordagem sobre o sistema prisional. Relatório do Seminário Radiografia do Sistema Prisional: Perspectivas e Desafios. Porto Alegre, 2008.

Zaffaroni, E.R; Pierangeli, J.H. Manual de direito penal brasileiro - parte geral. $4^{\mathrm{a}}$ ed. São Paulo: RT, 2002.

Hacia um realismo jurídico penal marginal. Caracas: Monte Avila, 1992.

. Criminología - aproximación desde um margen. $3^{\mathrm{a}}$ reimpressão.

Bogotá: Editorial Temis, 2003. 